MADELEINE LITA BARRIGA PUENTE DE LA VEGA

\title{
FITOMONITORAÇÃO E MODELAGEM DE FOTOSSÍNTESE EM JATOBÁ (Hymenaea courbaril L.) COM REDES NEURAIS
}

\section{ARTIFICIAIS}

Tese apresentada à Escola Politécnica da Universidade de São Paulo para obtenção do Título de Doutor em Engenharia Elétrica. 
MADELEINE LITA BARRIGA PUENTE DE LA VEGA

\section{FITOMONITORAÇÃO E MODELAGEM DE FOTOSSÍNTESE EM JATOBÁ (Hymenaea courbaril L.) COM REDES NEURAIS ARTIFICIAIS}

Tese apresentada à Escola Politécnica da Universidade de São Paulo para obtenção do Título de Doutor em Engenharia Elétrica.

Área de concentração:

Sistemas Digitais

Orientador:

Prof. Dr. Antonio Mauro Saraiva 


\section{FICHA CATALOGRÁFICA}

Puente de la Vega, Madeleine Lita Barriga

Fitomonitoração e modelagem de fotossíntese em jatobá (Hymenaea courbaril L.) com redes neurais artificiais /

Madeleine Lita Barriga Puente de la Vega. -- São Paulo, 2003. $188 \mathrm{p}$.

Tese (Doutorado) - Escola Politécnica da Universidade de São Paulo. Departamento de Engenharia de Computação e Sistemas Digitais.

1. Fitomonitoração 2. Modelagem 3. Redes neurais 4. Jatobá 5. Fotossíntese 6. Seqüestro de carbono 7. Efeito estufa I. Universidade de São Paulo. Escola Politécnica. Departamento de Engenharia de Computação e Sistemas Digitais II. t. 
Con todo mi afecto a la memoria de mi mamá Rosa, a mi papá Victor, a mis hermanos Yulian y Roxana, y a mi sobrina, "la pequeña" Carmen Rosa. 


\section{AGRADECIMENTOS}

A Deus pela presença na minha vida, por todas suas benções.

Ao meu orientador Prof. Dr. Antonio Mauro Saraiva, pelas diretrizes, apoio e incentivo constante na realização deste trabalho. Por sua amizade, confiança, carinho, conselhos e paciência.

Ao Prof. Dr. Marcos Silveira Buckeridge, do Instituto de Botânica, pela coorientação na parte da fisiologia vegetal, pelo apoio, colaboração e atenção. O Dr. Marcos colocou a disposição desta pesquisa todos os instrumentos de fitomonitoração, e as instalações do local da experimentação.

Ao Prof. Dr. Hernán Prieto Schmidt, do Departamento de Energia e Automação Elétrica (PEA), pela "co-orientação" na parte de redes neurais artificiais, pelo apoio e a sua gentileza. O Prof. Hernán disponibilizou para este trabalho o programa MLP1.

Ao Prof. Dr. Carlos Alberto Labate, da Escola Superior de Agricultura "Luiz de Queiroz" (ESALQ). O Prof. Carlos sugeriu a idéia de quantificar $\mathrm{CO}_{2}$ nas plantas. Com ele começou a proposta de fitomonitoração e modelagem de fotossíntese na escala de um estande de eucaliptos, mas por ser um projeto a longo prazo não se concretizou essa pesquisa.

Ao Dr. Henrique Pessoa dos Santos, ex-pesquisador do Instituto de Botânica e atual pesquisador da Embrapa Uva e Vinho, por todo o apoio na parte experimental deste trabalho, que ele ajudou a definir. Sou grata ao Henrique por todas as atenções, por explicar-me as dúvidas na parte de fisiologia e pela sua amizade.

À técnica Ana Maria Baroni. Ela me ensinou a realizar medidas com os instrumentos, sempre esteve atenta a qualquer dificuldade que estes apresentavam, e 
substituía-me em eventuais ausências. Agradeço à Ana Maria por toda a colaboração e a sua amizade.

Ao Sergio Miranda pela gentileza de fazer as correções do texto da minha tese e pelas sugestões.

À minha amiga Lourdes, doutoranda do Instituto de Botânica por suas explicações sobre o processo de fotossíntese, e pelo seu carinho.

Ao meu ex-orientador Prof. Dr Javier Ramírez-Fernández por permitir-me mudar de área de pesquisa e pela sua amizade. À sua esposa Nadejda por seus conselhos e carinho.

À minha amiga Nathalia por estar sempre comigo nas situações boas e nas dificuldades; com ela aprendi muitas coisas. Aos seus pais, Estanislau e Glória, e ao seu irmão Guilherme pelo carinho e amizade.

Aos meus amigos Gabriela, German, Hilda, Leoncio, Marco, Nair, Vaidya e Yolanda, por todo seu apoio e colaboração.

Aos colegas e amigos do LAA Alerso, Antonio, Augusto, Cristian, Daniel, Etienne, Fábio, Isis, Leonardo, Jacinto, Marcio, Miguel, Rafael e Renato

Aos amigos do Instituto de Botânica, Seção de Fisiologia e Bioquímica de Plantas.

Para finalizar agradeço à FAPESP por financiar este trabalho através do projeto Auxilio à Pesquisa "Fitomonitoração e modelagem de fotossíntese em Hymenaea courbaril L. (jatobá)". À CAPES por conceder-me a bolsa de doutorado. 


\section{SUMÁRIO}

\section{LISTA DE FIGURAS}

\section{LISTA DE TABELAS}

\section{LISTA DE ABREVIATURAS}

RESUMO

\section{ABSTRACT}

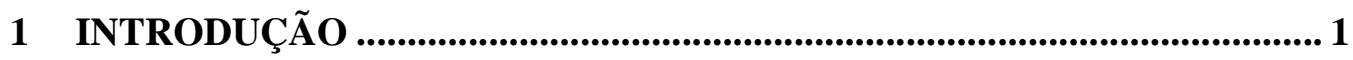

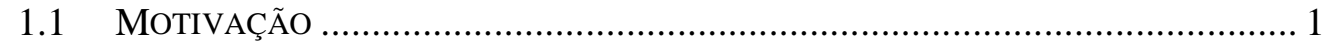

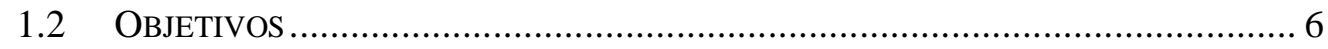

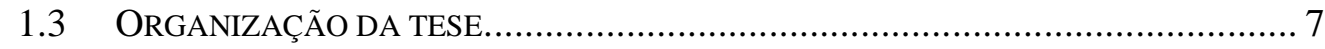

2 SEQÜESTRO DE CARBONO E MODELOS DE FLUXO E TROCA DE

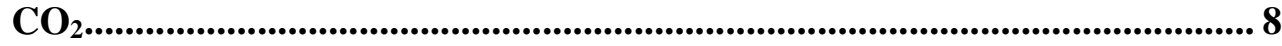

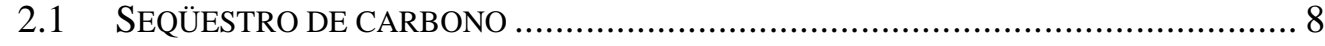

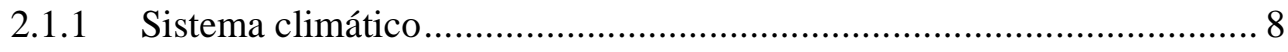

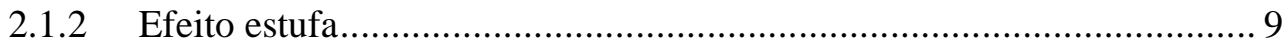

2.1.3 Resposta dos ecossistemas às mudanças da concentração de $\mathrm{CO}_{2}$ da

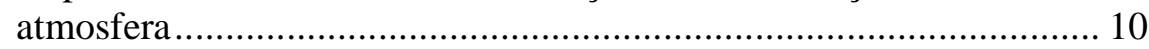

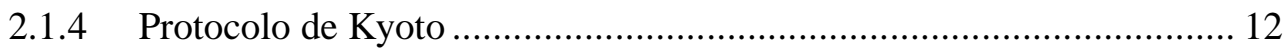

2.1.5 Créditos de carbono ...................................................................... 13

2.2 ESTADO DA ARTE DE MODELOS DE FLUXO E TROCA DE $\mathrm{CO}_{2} \ldots \ldots \ldots \ldots \ldots \ldots \ldots \ldots$

3 FUNDAMENTO TEÓRICO ........................................................................... 24

3.1 ConCEITOS BÁSICOS DE ECOFISIOLOGIA VEGETAL .................................... 24

3.1.1 Troca de gás nas plantas ........................................................... 24

3.1.2 Estômato...................................................................................... 25

3.1.2.1 Fatores que afetam a abertura e o fechamento dos estômatos......... 26

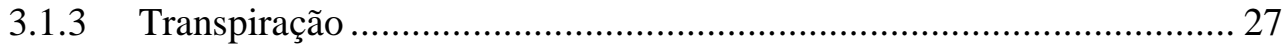

3.1.3.1 Controle da transpiração............................................................ 28

3.1.3.2 Fatores que afetam a taxa de transpiração .................................. 29

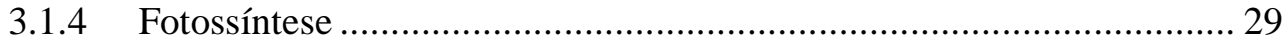

3.1.4.1 A luz como fonte primária de energia ........................................ 30

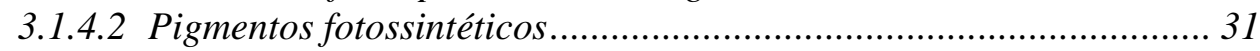

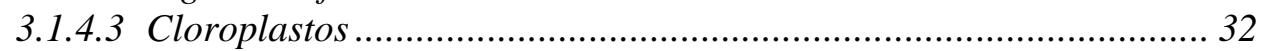

3.1.4.4 Fatores que afetam a fotossíntese .............................................. 33

3.2 CONCEITOS BÁSICOS SOBRE REDES NEURAIS ARTIFICIAIS (ANNS)............... 36

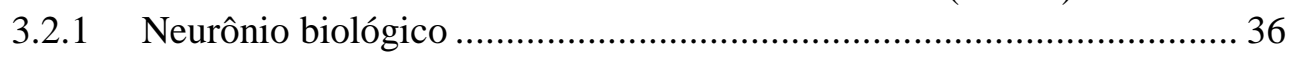

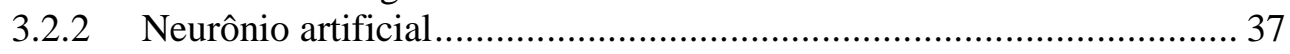

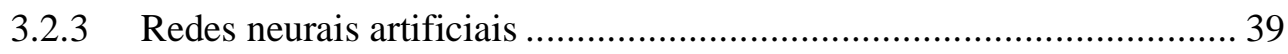

3.2.3.1 Arquiteturas típicas de ANNs................................................... 40

3.2.3.2 Tipos de aprendizado (treinamento).............................................. 41

3.2.3.3 Função de ativação (função de transferência) ............................... 42

3.2.4 Redes MLP (Multilayer Perceptron)............................................... 43 
3.2.5 Aplicação das redes neurais artificiais 49

4 MÉTODO PARA FITOMONITORAÇÃO E MODELAGEM DE FOTOSSÍNTESE BASEADO EM ANNs................................................50

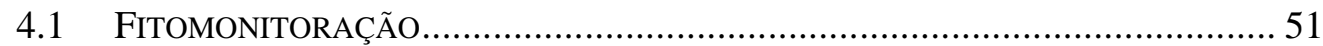

4.1.1 Variáveis fisiológicas e ambientais medidas...................................... 51

4.1.2 Local da experimentação........................................................ 53

4.1.3 Sistema de fitomonitoração ...................................................... 55

4.1.4 Procedimento para a coleta de dados ............................................. 57

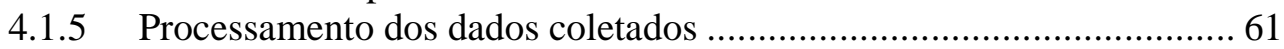

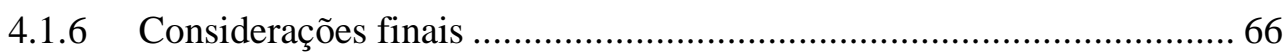

4.2 MODELAGEM DE FOTOSSÍNTESE COM REDES NEURAIS ARTIFICIAIS ...............67 67

4.2.1 Preparo dos conjuntos de dados para o treinamento e o teste ...............68 68

4.2.2 Definição da arquitetura da rede e parâmetros de treinamento .............. 70

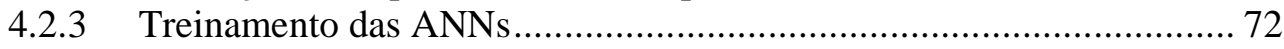

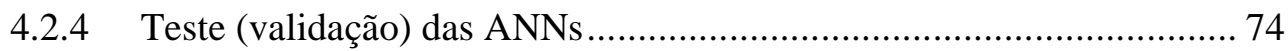

5 RESULTADOS E DISCUSSÃO ...................................................... 75

5.1 RESULTADOS E DisCUSSÃO DA FITOMONITORAÇÃO (COLETA DE DADOS) ...... 75

5.1.1 Resultados e análise das variáveis fisiológicas ................................. 76

5.1.2 Resultados e análise das variáveis ambientais................................... 84

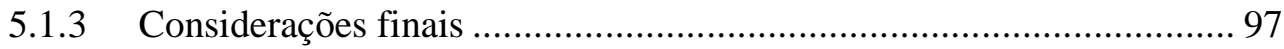

5.2 RESULTADOS E DISCUSSÃO DA MODELAGEM COM REDES NEURAIS

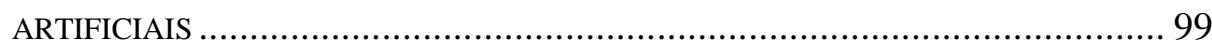

5.2.1 Primeira fase: modelagem do ciclo diário de fotossíntese por estação 100

5.2.1.1 Considerações iniciais.................................................................. 100

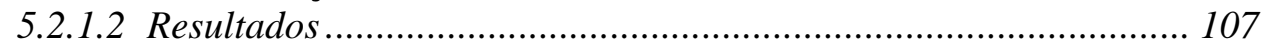

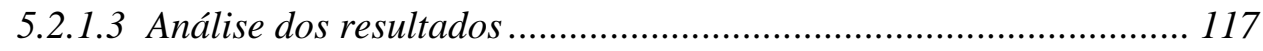

5.2.1.4 Considerações finais................................................................ 147

5.2.2 Segunda fase: modelagem do ciclo diário de fotossíntese por ano ..... 150

5.2.2.1 Considerações iniciais ............................................................. 150

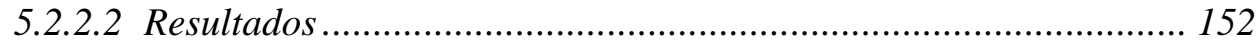

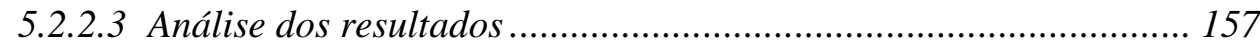

5.2.2.4 Considerações finais............................................................. 171

6 CONSIDERAÇÕES FINAIS................................................................ 173

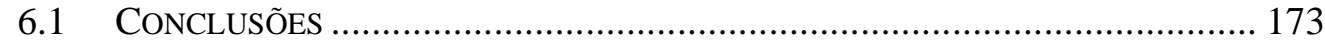

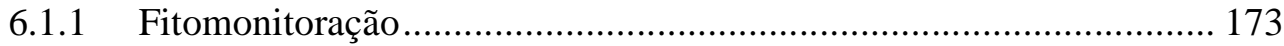

6.1.2 Modelagem de fotossíntese com redes neurais artificiais ................. 175

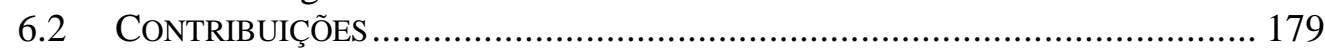

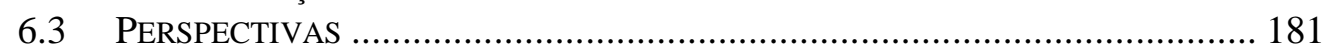

$\begin{array}{ll}\text { BIBLIOGRAFIA } & 183\end{array}$

APÊNDICE A Resultados dos treinamentos da primeira fase da modelagem

APÊNDICE B Resultados dos treinamentos da segunda fase da modelagem xxvii 


\section{LISTA DE FIGURAS}

Figura 3.1 Troca de gás na folha.

Figura 3.2 Representação esquemática do estômato, (a) estômato aberto (b) estômato fechado.

Figura 3.3 Fases da fotossíntese (LOUREIRO, et al., 2003).

Figura 3.4 Características das várias regiões de comprimento de onda da luz (LOUREIRO, et al., 2003).

Figura 3.5 Estrutura do cloroplasto (LOUREIRO, et al., 2003). 33

Figura 3.6 Resposta da fotossíntese a diferentes intensidades luminosas $\quad 34$

Figura 3.7 Esquemas simplificado de um neurônio biológico. 37

Figura 3.8 Esquema de um neurônio artificial com função de ativação. 38

Figura 3.9 Ilustração de redes feedforward. 41

Figura 3.10 Funções de ativação (a) Função logistic (b) Função tangente hiperbólica. $\quad 43$

Figura 3.11 Rede neural MLP com algoritmo de treinamento backpropagation. 44

Figura 4.1 Jatobá, Hymenaea courbaril, (LORENZI, 1992). 52

Figura 4.2 Plântulas de jatobá e sistema de medida portátil. 53

Figura 4.3 Casa de vegetação onde foram colocadas as plântulas de jatobá. $\quad 54$

Figura 4.4 Estande, onde colocaram-se as plântulas, coberto com tela sombrite para reduzir a radiação. $\quad 54$

Figura 4.5 Diagrama em blocos do sistema de fitomonitoração. 55

Figura 4.6 Instrumentos de medida utilizados para o sistema de monitoração, figuras adaptadas (LI-COR, 1999; LI-COR, 1998; OPTI-SCIENCES, 1998).

Figura 4.7 Estratificação do jatobá para a monitoração. 57

$\begin{array}{ll}\text { Figura 4.8 Vista de como se realizavam as medidas. } & 59\end{array}$

Figura 4.9 Vista em detalhe de como se realizavam as medidas. 60

Figura 4.10 Fluorômetro e os acessórios para realizar medidas de fluorescência (OPTI-SCIENCES, 1998). 61

$\begin{array}{ll}\text { Figura 4.11 Estrutura de rede MLP utilizada para modelar fotossíntese. } & 71\end{array}$

$\begin{array}{ll}\text { Figura 5.1 Medidas de fotossíntese líquida das quatro estações. } & 77\end{array}$

$\begin{array}{ll}\text { Figura 5.2 Medidas da condutância estomática das quatro estações. } & 79\end{array}$

Figura 5.3 Medidas da taxa de transpiração das quatro estações. $\quad 80$

$\begin{array}{ll}\text { Figura 5.4 Medidas de fluorescência de três estações. } & 82\end{array}$

Figura 5.5 Medidas da temperatura da folha das quatro estações. 83

Figura 5.6 Medidas da temperatura do ar das quatro estações. $\quad 85$

Figura 5.7 Medidas da concentração de $\mathrm{CO}_{2}$ do ar das quatro estações. $\quad 86$

Figura 5.8 Medidas da umidade relativa do ar das quatro estações. $\quad 88$

Figura 5.9 Medidas da radiação fotossintética ativa, dentro da câmara, (PARi) das quatro estações.

Figura 5.10 Medidas da concentração de $\mathrm{CO}_{2}$ na câmara da folha das quatro estações.

Figura 5.11 Medidas da umidade relativa na câmara da folha das quatro estações.

Figura 5.12 Medidas da radiação fotossintética ativa, fora da câmara, (PARo) das quatro estações. 
Figura 5.13 Fotossíntese (a) valores calculados pela ANN e valores medidos (b) Oscilações das medidas de fotossíntese na faixa de -0,099 a 0,099. 104

Figura 5.14 Resultados da modelagem do ciclo diário de fotossíntese para a combinação 1 (6 variáveis de entrada).

Figura 5.15 Resultados da modelagem do ciclo diário de fotossíntese para a combinação 6 (7 variáveis de entrada).

Figura 5.16 Resultados da modelagem do ciclo diário de fotossíntese para a combinação 11 ( 8 variáveis de entrada).

Figura 5.17 Resultados dos treinamentos, das 18 combinações de variáveis de entrada, do primeiro conjunto de treinamento.

Figura 5.18 Resultados dos treinamentos, das 18 combinações de variáveis de entrada, segundo conjunto de treinamento.

Figura 5.19 Resultados do primeiro e segundo conjunto de treinamento, para as estações do outono e do inverno.

Figura 5.20 Resultados do primeiro e segundo conjunto de treinamento, para as estações da primavera e do verão.

Figura 5.21 Resultados dos treinamentos, das 4 estações, do primeiro conjunto. 130

Figura 5.22 Resultados dos treinamentos, das 4 estações, do segundo conjunto. 131

Figura 5.23 Resultados do treino e do teste das ANNs, das estações do outono e do inverno, primeiro conjunto de treinamento (com todos os dados). 135

Figura 5.24 Resultados do treino e do teste das ANNs, das estações da primavera e do verão, primeiro conjunto de treinamento (com todos os dados). 136

Figura 5.25 Diferença do erro relativo médio, entre o teste e o treino das ANNs, dos 3 níveis, para as 4 estações, primeiro conjunto de treinamento. 138

Figura 5.26 Erro relativo médio, do treino e do teste das ANNs, das estações do outono e do inverno, segundo conjunto de treinamento (com dados filtrados).

Figura 5.27 Erro relativo médio, do treino e do teste das ANNs, das estações da primavera e do verão, segundo conjunto de treinamento (com dados filtrados).

Figura 5.28 Diferença do erro relativo médio, entre o teste e o treino das ANNs, dos 3 níveis, para as 4 estações, segundo conjunto de treinamento. 141

$\begin{array}{ll}\text { Figura 5.29 Convergência do treinamento das ANNs, primeiro conjunto. } & 144\end{array}$

Figura 5.30 Convergência do treinamento das ANNs, segundo conjunto. 145

Figura 5.31 Resultados da modelagem do ciclo diário de fotossíntese para a combinação 1.

Figura 5.32 Resultados da modelagem do ciclo diário de fotossíntese para a combinação 5.

Figura 5.33 Resultados da modelagem do ciclo diário de fotossíntese para a combinação 7.

Figura 5.34 Resultados dos treinamentos, das 10 combinações de variáveis de entrada.

$\begin{array}{ll}\text { Figura 5.35 Resultados do primeiro e segundo conjunto de treinamento. } & 161\end{array}$

Figura 5.36 Resultados do treino e do teste das ANNs 164

Figura 5.37 Diferença do erro relativo médio, entre o teste e o treino das ANNs, dos três níveis.

Figura 5.38 Convergência do treinamento das ANNs, primeiro conjunto. 168

$\begin{array}{ll}\text { Figura 5.39 Convergência do treinamento das ANNs, segundo conjunto. } & 169\end{array}$ 


\section{LISTA DE TABELAS}

Tabela 4.1 - Equipamentos utilizados para o sistema de monitoração.

Tabela 4.2 - Horário de medidas das variáveis fisiológicas (exceto área foliar e fluorescência) e variáveis ambientais.

Tabela 4.3 - Horário de medidas de fluorescência.

Tabela 4.4 - Exemplo de um arquivo gerado pelo medidor de fotossíntese portátil. 62

Tabela 4.5 - Exemplo de um arquivo que contém as medidas de um curso diário (lista parcial dos dados), medidas realizadas com o medidor de fotossíntese.

Tabela 4.6 - Exemplo de um arquivo gerado pelo fluorômetro.

Tabela 4.7 - Exemplo de um arquivo que contém as medidas de um curso diário, lista parcial dos dados, medidas realizadas com o fluorômetro.

Tabela 4.8 - Variáveis de entrada e saída utilizadas no treinamento e no teste das ANNs.

Tabela 4.9 - Lista parcial de um arquivo de treinamento. 70

Tabela 4.10 - Parâmetros de treinamento utilizados nesta pesquisa. $\quad 72$

Tabela 4.11 - Lista parcial dos resultados de um treinamento de rede neural. $\quad 73$

Tabela 5.1 - Características da fotossíntese no jatobá das quatro estações do ano. 78

Tabela 5.2 - Maiores valores atingidos de condutância estomática, taxa de transpiração e taxa de fotossíntese nas quatro estações do ano.

Tabela 5.3 - Características das medidas da temperatura da folha, das quatro estações do ano.

Tabela 5.4 - Características da temperatura do ar, medidas na câmara da folha, das quatro estações do ano.

Tabela 5.5 - Características das medidas de concentração de $\mathrm{CO}_{2}$ do ar.

Tabela 5.6 - Características das medidas da umidade relativa do ar, das quatro estações do ano.

Tabela 5.7 - Características das medidas da radiação fotossintética ativa dentro da câmara da folha (PARi), das quatro estações do ano.

Tabela 5.8 - Características das medidas de concentração de $\mathrm{CO}_{2}$ na câmara da folha.

Tabela 5.9 - Características das medidas da umidade relativa na câmara da folha, das quatro estações do ano.

Tabela 5.10 - Características das medidas da radiação fotossintética ativa fora da câmara da folha (PARo), das quatro estações do ano.

Tabela 5.11 - Combinações de variáveis de entrada utilizadas no treinamento. 101

Tabela 5.12 - Primeiro quadro dos casos treinados para modelar fotossíntese. 102

Tabela 5.13 - Segundo quadro dos casos treinados, primeiro conjunto (com todos os dados).

105

Tabela 5.14 - Segundo quadro dos casos treinados, segundo conjunto (com dados filtrados).

Tabela 5.15 - Número de vetores de treinamento e de teste para o primeiro conjunto (com todos os dados). 
Tabela 5.16 - Número de vetores de treinamento e de teste para o segundo conjunto (com dados filtrados).

Tabela 5.17 - Casos com os que se obtiveram os melhores resultados, primeiro conjunto de treinamento, com todos os dados.

Tabela 5.18 - Casos com os que se obtiveram os melhores resultados, segundo conjunto de treinamento, com dados filtrados.

Tabela 5.19 - Lista parcial dos resultados do treinamento para a combinação 1 (6 variáveis de entrada), primeiro conjunto (com todos os dados). 115

Tabela 5.20 - Lista parcial dos resultados do teste para a combinação 1 (6 variáveis de entrada), primeiro conjunto (com todos os dados). 116

Tabela 5.21 - Influência das variáveis de entrada nos resultados do treinamento. 124

Tabela 5.22 - Comparação dos resultados do treinamento, com todos os dados e com dados filtrados.

Tabela 5.23 - Combinações de variáveis de entrada utilizadas no treinamento. 151

Tabela 5.24 - Número de vetores de treinamento e de teste.

Tabela 5.25 - Casos com os que se obtiveram os melhores resultados no treinamento das ANNs.

Tabela 5.26 - Influência das variáveis de entrada nos resultados do treinamento. 160

Tabela 5.27 - Comparação dos resultados do treinamento, com todos os dados e com dados filtrados.

Tabela 5.28 - Comparação dos resultados dos treinamentos, da primeira fase com a segunda fase, correspondentes ao segundo conjunto de treinamento, ao nível 1, e à combinação 11 . 


\section{LISTA DE ABREVIATURAS}

$\begin{array}{ll}\text { IRGA } & \text { Infrared Gas Analyzer } \\ \text { IPCC } & \text { Intergovernmental Panel on Climate Change } \\ \text { ANN } & \text { Artificial Neural Network } \\ \text { PAR } & \text { Photosynthetically Activity Radiation } \\ \text { UNFCCC } & \text { United Nations Framework Convention on Climate Change } \\ \text { GCM } & \text { General Circulation Models } \\ \text { NPP } & \text { Net Primary Produtiviry } \\ \text { MLP } & \text { Multilayer Perceptron } \\ \text { MLFF } & \text { Multilayer Feedforward } \\ \text { ATP } & \text { Adenosine triphosphate } \\ \text { NADPH } & \text { Nicotinamide adenine dinucleotide phosphate } \\ \text { DFF } & \text { Densidade do Fluxo Fotônico }\end{array}$




\section{RESUMO}

$\mathrm{O}$ aumento das concentrações dos gases-estufa, principalmente o dióxido de carbono, e as mudanças climáticas se tornaram assuntos científico, econômico e político importantes nos últimos anos. O "Mecanismo de Desenvolvimento Limpo", do Protocolo de Kyoto concede "créditos de carbono" comercializáveis para projetos que promovam o "seqüestro de carbono" nos países em desenvolvimento. Portanto, avaliar a capacidade de absorção de $\mathrm{CO}_{2}$ pela vegetação terrestre é um aspecto importante, o que justifica o interesse em desenvolver modelos de fluxo e troca desse gás em diferentes escalas. O desenvolvimento desses modelos é dificultado pela não-linearidade dos processos ecofisiológicos. Este trabalho apresenta um método de modelagem de fotossíntese no nível da folha, como um primeiro passo para um método de quantificação do potencial de "seqüestro de carbono". A técnica utilizada foi a de redes neurais artificiais, uma vez que ela permite ajustar relações não lineares entre as variáveis de entrada e de saída. O trabalho foi divido em duas partes: fitomonitoração e modelagem. A fitomonitoração foi realizada em jatobá (Hymenaea courbaril), durante um ano. Medindo-se variáveis fisiológicas: taxa de fotossíntese, taxa de transpiração, condutância estomática, temperatura da folha, e fluorescência, e variáveis ambientais: concentração de $\mathrm{CO}_{2}$, radiação fotossintética ativa, umidade relativa e temperatura do ar. Uma quantidade de dados inédita para esse tipo de experimento e para essa espécie vegetal foi obtida. A análise dos resultados da fitomonitoração mostra características importantes sobre o comportamento das variáveis fisiológicas em plântulas de jatobá e das variáveis ambientais de seu entorno, casa de vegetação, nas quatro estações do ano. Os dados coletados foram utilizados para a modelagem da rede neural. Os treinamentos foram realizados com diferentes combinações de variáveis de entrada para observar qual era o conjunto de variáveis às quais a rede respondia melhor. A análise dos resultados dos treinamentos mostrou que com a técnica de redes neurais é possível atingir uma aproximação da função fotossíntese com $92 \%$ de acertos para entradas com dados filtrados. 


\begin{abstract}
The increases in "greenhouse gas" concentrations, mainly carbon dioxide, and the climatic changes have become important scientific, economic, and political subjects in the past years. The Kyoto Protocol establishes the Clean Development Mechanism, which grants "carbon credits" for projects that promote the "sequestration of carbon" in developing countries. Therefore, it is important to evaluate the $\mathrm{CO}_{2}$ absorption capacity by terrestrial plants, and this requires the development of gas flow and gas exchange models in different scales. That development is usually complicated, because the ecophysiological processes are non-linear. This work presents a method to model photosynthesis at the leaf level, as a first step toward quantifying the potential of "carbon sequestration". The technique used was artificial neural networks (ANNs), as it allows the adjustment of non-linear relationships between input and output variables. The work was divided in two parts: phytomonitoring and modeling. The phytomonitoring was accomplished in jatoba (Hymenaea courbaril) during one year. The following physiologic variables were measured: photosynthesis rate, transpiration rate, stomatal conductance, leaf temperature, and fluorescence; and environmental variables: $\mathrm{CO}_{2}$ concentration, photosynthetic activity radiation, relative humidity, and air temperature. An unprecedented amount of data for that type of experiment and for that plant species was obtained. The analysis of these data showed important characteristics about the relationship of the physiologic variables in Hymenaea courbaril and the environmental variables, in the four seasons. The data collected were used for the modeling and fine-tuning of the neural network. The network was trained with different combinations of input variables to observe to which group of variables the neural network responded better. The analysis of the training results showed that with the ANN technique it is possible to achieve a very good approximation of the photosynthesis function, with $92 \%$ success rate for entries consisting of filtered data.
\end{abstract}




\section{INTRODUÇÃO}

\subsection{Motivação}

$\mathrm{O}$ aumento da concentração de $\mathrm{CO}_{2}$ atmosférico e as mudanças de clima têm feito do balanço de carbono global um tópico científico e político importante. Muitos pesquisadores concordam que os processos bióticos no ecossistema terrestre cumpriram um papel crítico na determinação de como as emissões de $\mathrm{CO}_{2}$ antropogênicas e o clima podem interatuar no futuro (HAM e KNAPP, 1998).

Os níveis de $\mathrm{CO}_{2}$, um dos gases do efeito estufa que se encontra na atmosfera da Terra, têm aumentado desde a época pré-industrial, principalmente devido à combustão de combustíveis fósseis, ao desmatamento e às mudanças do uso da terra (GOLUBYATNIKOV, et al., 1998).

Tanto a queima de combustíveis fósseis como o desmatamento liberam aproximadamente sete bilhões de toneladas métricas (sete gigatoneladas) de carbono na atmosfera a cada ano. Uma parte dessa emissão, três gigatoneladas a cada ano, se acumula na atmosfera. Modelos predizem que os oceanos capturam duas gigatoneladas; os pesquisadores suspeitam que as duas gigatoneladas restantes poderiam ser capturadas pelas plantas terrestres e o solo (UNISCI SCIENCE, 1999).

Atualmente são pesquisados os mecanismos de armazenamento de carbono, ou sumidouros, para explicar porque o nível de dióxido de carbono é menor do que se esperava com o aumento das emissões. Alguns pesquisadores avaliam o potencial da floresta para atuar como um sumidouro de $\mathrm{CO}_{2}$ atmosférico. Fala-se da fertilização por $\mathrm{CO}_{2}$, que é a intensificação da produtividade basicamente da vegetação terrestre (um maior crescimento das plantas) produzida por efeito de uma

concentração elevada de $\mathrm{CO}_{2}$ na atmosfera (WARD e STRAIN, 1999; WHITE, et al., 1999; MUDRIK, et al., 1997). 
Os fluxos de $\mathrm{CO}_{2}$ entre a atmosfera e a terra dependem da forma como o $\mathrm{CO}_{2}$ é emitido e removido pela vegetação e pelo solo; por meio da administração do uso da terra e dos recursos florestais, os países podem potencialmente afetar as concentrações de $\mathrm{CO}_{2}$ atmosférico (LIM, et al., 1999).

No Brasil, o desmatamento é uma questão importante com reflexos no ciclo de carbono. A Amazônia contém a metade da floresta tropical restante do mundo. Hoje, essas florestas estão experimentando rapidamente mudanças sem precedentes, função principalmente do desmatamento acelerado, que terão maior impacto na biodiversidade, na hidrologia regional e no ciclo do carbono (LAURANCE, 1998). Em 1999, estudos demonstraram que uma imensa área está sendo desmatada e que milhares de quilômetros quadrados da floresta são prejudicados por incêndios e corte de árvores a cada ano, os quais são invisíveis em imagem de satélite (LAURANCE e FEARNSIDE, 1999).

Os efeitos do desmatamento incluem emissão de gases do efeito estufa, perdas da diversidade cultural, degradação da terra e de fontes de água e possíveis impactos no clima regional. As duas fontes principais de emissões de gases do efeito estufa são combustão de combustíveis fósseis e práticas agrícolas. Uma terceira fonte resulta do desmatamento das florestas tropicais (FUJISAKA, et al., 1998).

A preocupação com o aumento das emissões de $\mathrm{CO}_{2}$ resultou na realização da conferência de Kyoto, em dezembro 1997, na qual foram definidas metas de redução de dióxido de carbono na atmosfera (MARLAND e SCHLAMADINGER, 1999; WALSH, 1999). Os primeiros passos foram dados na Conferência do Rio, em 1992, onde foi assinada a Convenção das Nações Unidas sobre Mudanças de Clima. Nessa ocasião já existia a preocupação com o efeito estufa e a elevação da temperatura global, os quais produzem mudanças de clima, resultando em furacões, enchentes, secas e a elevação dos níveis dos oceanos. Cada vez mais se relaciona o aumento da concentração de $\mathrm{CO}_{2}$ atmosférico com as mudanças de clima (IPCC, 1997). 
O Protocolo de Kyoto, cujo objetivo central é que a humanidade contribua lentamente para o aumento das concentrações de $\mathrm{CO}_{2}$ atmosférico, que ameaça o planeta com mudanças de clima rápidas e prejudiciais, reconhece que sumidouros de carbono, tais como florestas e solos, atuam para capturar e armazenar aquele gás (WALSH, 1999).

Um dos pontos importantes do Protocolo de Kyoto, o artigo 12, estabelece o "Mecanismo de Desenvolvimento Limpo", o qual concede "créditos de carbono" comercializáveis para projetos que promovam o "seqüestro de carbono" nos países em desenvolvimento (CANADELL e MOONEY, 1999; LEBLANK, 1999; MARLAND e SCHLAMADINGER, 1999).

A inclusão da produção florestal como uma opção de seqüestro de carbono ou de sumidouro de $\mathrm{CO}_{2}$ é crítica para a implementação com sucesso da Convenção das Nações Unidas sobre a Mudança de Clima. Como o comércio de emissões e outros instrumentos econômicos relacionados serão provavelmente usados para definir os objetivos do tratado, a integração dos créditos de carbono do setor da silvicultura dentro do sistema de comércio de emissões e dentro do Mecanismo de Desenvolvimento Limpo é necessária para utilizar efetivamente o potencial de mitigação dos gases do efeito estufa por parte da floresta (LEBLANC, 1999).

O Mecanismo de Desenvolvimento Limpo está abrindo uma nova opção de mercado ambiental, principalmente para países em desenvolvimento e localizados em regiões tropicais. O Brasil é reconhecido por especialistas internacionais como um dos países de maior capacidade de resgate de $\mathrm{CO}_{2}$, além de apresentar baixo nível de emissão, menos de 0,5 t/habitante/ano, enquanto nos Estados Unidos, que é o maior emissor, a relação é de 6.000 t/habitante/ano (RPD, 2000). Na prática, no Brasil, algumas empresas já estão fazendo uso desta opção de mercado, tais como o Projeto Plantar (substituição de combustível fóssil por combustível vegetal), Projeto SASA (aproveitamento de biogás gerado em aterro sanitário), Projeto ECONERGY (coogeração de energia elétrica com biomassa)*.

\footnotetext{
* Informação obtida no Primeiro seminário PROGESA - Créditos de Carbono, FEA-USP, junho 2003.
} 
Para atender os compromissos do Protocolo de Kyoto e a Convenção das Nações Unidas sobre Mudanças de Clima, as nações necessitam de informação precisa sobre a variabilidade dos níveis de troca de $\mathrm{CO}_{2}$ em seus sistemas bióticos e sobre como os homens estão modificando essas trocas. Além disso, o valor econômico elevado do sumidouro de carbono terrestre coloca numa alta prioridade entender o controle atual e futuro da fonte - sumidouro da dinâmica do carbono (CANADELL e MOONEY, 1999).

Portanto, avaliar a capacidade de absorção de $\mathrm{CO}_{2}$ pela vegetação terrestre é um aspecto importante devido às implicações ecológicas e econômicas. Por isso, nos últimos anos foram desenvolvidos modelos de fluxos e troca de $\mathrm{CO}_{2}$ em diferentes escalas (ANDERSON, et al., 2000; GOLUBYATNIKOV, et al., 1998; KORZUKHIN, et al., 1995,).

A modelagem ecológica tem crescido rapidamente nas três últimas décadas. Para desenvolver modelos, o ecólogo dispõe de diversos métodos, percorrendo desde métodos numéricos, matemáticos e estatísticos até técnicas originadas da inteligência artificial, tais como sistemas especialistas, algoritmos genéticos e redes neurais artificiais (LEK e GUÉGAN, 1999).

Redes neurais artificiais são ferramentas computacionais que têm surgido nas últimas décadas e encontrado ampla aceitação em muitas disciplinas, para a modelagem de problemas complexos do mundo real. As redes neurais artificiais imitam o processo de aprendizado do cérebro humano e podem processar problemas que envolvem dados complexos e não lineares. Assim, elas são adequadas para a modelagem de dados ecológicos, os quais são conhecidos por ser muito complexos e freqüentemente não lineares (BASHEER e HAJMEER, 2000; LEK e GUÉGAN, 1999; ZHANG, et al., 1998).

O cálculo da taxa de fotossíntese é baseado no modelo bioquímico complexo, no nível de sub-organela, de Farquhar e von Caemmerer, o qual é considerado freqüentemente entre os biólogos como um modelo de referência para fotossíntese. 
Por causa da complexidade dos mecanismos de reação bioquímica e dos muitos coeficientes que dependem das espécies de plantas, apenas é possível validar certas partes do modelo (INFANTE, et al., 1999).

A resposta da fotossíntese da folha a variáveis ambientais (radiação, temperatura e umidade) é não linear, o que causa consideráveis erros no cálculo diário da fotossíntese, sem considerar a variabilidade diária das variáveis (CHEN, et al., 1999). Portanto, utilizar a técnica de redes neurais artificiais é uma alternativa para lidar com esse problema não linear.

Tanto na modelagem de fluxos e troca de gás como na modelagem de processos ecofisiológicos (fotossíntese, condutância estomática, transpiração) geralmente são utilizadas técnicas convencionais, pelo que técnicas da inteligência artificial têm um potencial de aplicação a ser explorado nessa área. Esta razão encoraja a propor a modelagem de fotossíntese com redes neurais artificiais.

Este trabalho visou a modelagem de fotossíntese, no nível da folha, em Hymenaea courbaril L. (jatobá), utilizando a técnica de redes neurais artificiais, como um passo inicial para a quantificação do potencial de seqüestro de $\mathrm{CO}_{2} \mathrm{em}$ plantas. Para isso monitoraram-se dados, durante o período de um ano, de variáveis fitofisiológicas como fotossíntese líquida, transpiração, condutância estomática, temperatura da folha, área foliar e fluorescência, e de variáveis ambientais como radiação fotossintética ativa, umidade relativa, temperatura e concentração de $\mathrm{CO}_{2}$. Os dados coletados foram analisados para se observar como foi o comportamento das variáveis fisiológicas e ambientais monitoradas, em cada uma das estações do ano. Redes neurais artificiais, baseadas no modelo multilayer perceptron, foram treinadas com os dados coletados para se obter o modelo do ciclo diário de fotossíntese. Como dados de entrada foram utilizadas as variáveis ambientais, além da temperatura da folha, e como dado de saída foi utilizada a fotossíntese. Foi avaliada a sensibilidade do modelo às diferentes variáveis ambientais, para assim determinar o conjunto de variáveis às quais o modelo respondeu melhor. 
Este trabalho de pesquisa foi desenvolvido no Laboratório de Automação Agrícola - LAA, do Departamento de Engenharia de Computação e Sistemas Digitais, Escola Politécnica da Universidade de São Paulo, em associação com o Instituto de Botânica, Seção de Fisiologia e Bioquímica de Plantas, onde foi efetuada a parte experimental (coleta de dados), com a colaboração do pesquisador Dr. Marcos Silveira Buckeridge e equipe.

O sistema de fitomonitoração, ou seja, a instrumentação utilizada para realizar as medidas, foi financiada pelo Projeto Temático "Conservação e utilização sustentável da biodiversidade vegetal do cerrado e mata atlântica: os carboidratos de reserva e estruturais e seu papel no estabelecimento e manutenção das plantas em seu ambiente natural", processo FAPESP n 98/05124-8, dentro do projeto BIOTA, coordenado pelo Dr. Buckeridge.

Esta pesquisa foi financiada pelo Projeto de Auxílio a Pesquisa "Fitomonitoração e modelagem de fotossíntese em Hymenaea courbaril L. (jatobá)", processo FAPESP n 01/08046-2, coordenado pelo Dr. Saraiva.

\subsection{Objetivos}

O objetivo principal deste trabalho de pesquisa é modelar a fotossíntese líquida em Hymenaea courbaril (jatobá), usando redes neurais artificiais.

Os objetivos específicos associados são:

- Monitorar variáveis fitofisiológicas, em plântulas de jatobá, e variáveis ambientais, dentro de uma casa de vegetação, durante o período de um ano, para obter dados das quatro estações: outono, inverno, primavera e verão.

- Analisar os dados coletados, para verificar o comportamento da fotossíntese, da transpiração, da condutância estomática e da fluorescência no jatobá, assim como também o comportamento das variáveis ambientais, nas quatro estações do ano. 
- Modelar o ciclo diário de fotossíntese líquida, taxa de transpiração e condutância estomática, na escala da folha, em três níveis da planta, utilizando a técnica de redes neurais artificiais.

\subsection{Organização da tese}

A tese está formada por 6 capítulos. No capítulo 1 são dados a motivação e os objetivos da pesquisa. No capítulo 2 tratam-se dois assuntos: o primeiro trata aspectos relacionados com o seqüestro de carbono, e o segundo apresenta uma revisão do estado da arte de modelos de fluxo e troca de $\mathrm{CO}_{2}$. No capítulo 3 apresenta-se uma breve revisão de conceitos teóricos básicos sobre ecofisiologia vegetal e redes neurais artificiais. No capítulo 4 trata-se sobre o método de trabalho proposto e realizado, sendo apresentados o método de fitomonitoração e o método de modelagem de fotossíntese com redes neurais artificiais. No capítulo 5 são apresentados e discutidos os resultados da pesquisa. Primeiro trata-se da fitomonitoração e, a seguir, da modelagem do ciclo diário de fotossíntese com redes neurais artificiais. No capítulo 6 apresentam-se as conclusões, contribuições e perspectivas. 


\section{SEQÜESTRO DE CARBONO E MODELOS DE FLUXO E TROCA DE $\mathrm{CO}_{2}$}

Este capítulo apresentará dois aspectos: no item 2.1, tratar-se-á de assuntos relacionados com o seqüestro de carbono, tais como sistemas climáticos, efeito estufa, resposta dos ecossistemas às mudanças de concentração de $\mathrm{CO}_{2}$ da atmosfera, Protocolo de Kyoto e créditos de carbono; no item 2.2 apresentar-se-á uma revisão do estado da arte de modelos de fluxo e troca de $\mathrm{CO}_{2}$.

\subsection{Seqüestro de carbono}

\subsubsection{Sistema climático}

Segundo o Intergovernmental Panel on Climate Change (IPCC, 1997), o sistema climático consta dos seguintes componentes principais: a atmosfera, os oceanos, a biosfera terrestre e marinha, a criosfera (gelo marinho, cobertura de neve sazonal, glaciares de montanha e capas de gelo na escala continental) e a superfície terrestre. Esses componentes atuam entre si e o resultado dessa interação coletiva determina o clima da superfície da Terra. As interações se produzem através de fluxos de energia de diversas formas, de troca de vapor de água, de fluxos de outros gases, entre os quais figuram o dióxido de carbono $\left(\mathrm{CO}_{2}\right)$ e o metano $\left(\mathrm{CH}_{4}\right)$, e o ciclo de nutrientes. O que move o sistema climático é a entrada de energia solar, equilibrada pela emissão de energia infravermelha (“calor”) para o espaço. A energia solar é a força condutora mais importante dos movimentos da atmosfera e dos oceanos, dos fluxos de calor e água, e da atividade biológica.

Em seu estado natural, os diversos fluxos entre os componentes do sistema climático encontram-se, normalmente, muito próximos do equilíbrio exato quando se integram ao longo de períodos de um a vários decênios. Por exemplo, antes da revolução industrial, a absorção de dióxido de carbono por fotossíntese atingiu seu 
equilíbrio quase exato, mediante a liberação efetuada pelos restos de materiais vegetais e do solo, como o demonstram as concentrações quase constantes de $\mathrm{CO}_{2}$ na atmosfera, durante vários milênios até cerca de 1880. Mas, de um ano a outro se podem produzir desequilíbrios flutuantes, devido à variabilidade natural do sistema climático. A humanidade está afetando o desenvolvimento dos processos climáticos, por conseguinte, o equilíbrio natural do sistema climático, já que perturba, sem interrupção e a escala regional e mundial, a composição da atmosfera da Terra e as propriedades da superfície terrestre.

\subsubsection{Efeito estufa}

Segundo o Intergovernmental Panel on Climate Change (IPCC, 1997), a humanidade está alterando a concentração dos gases do efeito estufa e dos aerossóis, que influem no clima e, por sua vez, são influenciados por este. Os gases do efeito estufa reduzem a perda líquida da radiação infravermelha para o espaço e têm pouco impacto na absorção da radiação solar, o que faz com que a temperatura da superfície seja mais quente e produz o denominado "efeito estufa". Os aerossóis têm grande importância por seu impacto sobre a radiação solar, e têm quase sempre um efeito de esfriamento.

Certos gases do efeito estufa surgem naturalmente, mas estão influenciados direta ou indiretamente pelas atividades humanas, enquanto outros são totalmente antropogênicos. Os principais gases que surgem naturalmente são: vapor de água $\left(\mathrm{H}_{2} \mathrm{O}\right)$, dióxido de carbono $\left(\mathrm{CO}_{2}\right)$, ozônio $\left(\mathrm{O}_{3}\right)$, metano $\left(\mathrm{CH}_{4}\right)$ e óxido nitroso $\left(\mathrm{N}_{2} \mathrm{O}\right)$. Os principais grupos de gases do efeito estufa, completamente antropogênicos, são: clorofluorcarbonos (CFC), hidrofluorcarbonos (HFC) e hidroclorofluorcarbonos ( $\mathrm{HCFC})$, e as espécies totalmente fluoretadas, como o hexafluoreto de enxofre $\left(\mathrm{SF}_{6}\right)$.

O vapor de água é o maior contribuinte ao efeito estufa natural e é o que está mais diretamente vinculado ao clima, por conseguinte, menos diretamente controlado pela atividade humana. Isto devido a que a evaporação depende fortemente da temperatura da superfície, e porque o vapor de água atravessa a atmosfera em ciclos 
muito rápidos. Ao contrário, as concentrações dos demais gases do efeito estufa estão sujeitas à influência, forte e direta, das emissões associadas com a queima de combustíveis fósseis, com algumas atividades florestais, com a maioria das atividades agrícolas, e com a produção e a utilização de diversas sustâncias químicas.

No que se refere aos processos de eliminação, todos os gases do efeito estufa, exceto o dióxido de carbono, são eliminados em grande parte através de reações químicas ou fotoquímicas dentro da atmosfera. De maneira diferente, o dióxido de carbono efetua ciclos contínuos entre vários "reservatórios" ou depósitos de armazenamento temporários (atmosfera, plantas terrestres, solos, águas e sedimentos dos oceanos).

O efeito estufa é um fenômeno natural desejável, sem o qual não haveria clima propício no planeta para o florescimento da vida. É ele que faz o globo terrestre ser quente o suficiente para ser habitável. O aumento do efeito estufa, em razão da elevação exagerada dos níveis de dióxido de carbono atmosférico e outros gases, é que faz a temperatura esquentar mais do que o desejável, provocando o derretimento de geleiras e, eventualmente, colocando em risco o equilíbrio do planeta (PIVETA, 2002).

\subsubsection{Resposta dos ecossistemas às mudanças da concentração de $\mathrm{CO}_{2}$ da atmosfera}

As plantas dos ecossistemas terrestres desempenham uma função importante no ciclo do carbono terrestre, já que captam $\mathrm{CO}_{2}$ da atmosfera durante a fotossíntese e armazenam carbono como biomassa. As taxas de fotossíntese estão sujeitas à influência do tipo de planta, às concentrações de $\mathrm{CO}_{2}$ ambiental e à temperatura; e com frequiência estão condicionadas pela disponibilidade de nutrientes e umidade. As concentrações mais altas de $\mathrm{CO}_{2}$ ambiental poderiam intensificar o crescimento das plantas, devido ao efeito de fertilização por $\mathrm{CO}_{2}$ e ao uso mais eficiente da água. A resposta das plantas a concentrações mais elevadas de $\mathrm{CO}_{2}$ depende, em parte, do 
caminho fotossintético utilizado (isto é, que as plantas sejam $\mathrm{C} 3$ ou $\mathrm{C}^{*}$ ). Isto acrescenta diferenças regionais significativas à resposta das plantas a concentrações mais altas de $\mathrm{CO}_{2}$. A mudança climática também incide no crescimento das plantas de diversas formas. Uma temperatura mais cálida pode influir no aumento ou diminuição da taxa de fotossíntese, e tenderá a acelerar a respiração das plantas, o que devolve carbono à atmosfera. A decomposição da biomassa morta (efetuada predominantemente no solo), também libera $\mathrm{CO}_{2}$ à atmosfera; esta respiração do solo é função do tipo do solo, da temperatura do solo, da umidade e da disponibilidade de nutrientes. Por isso, as mudanças de concentração de $\mathrm{CO}_{2}$ ambiental e o clima influem na produtividade do ecossistema de forma muito complexa e não linear (IPCC, 1997).

A interação entre os ecossistemas terrestres e a atmosfera se dá através de numerosos processos, incluindo a troca de $\mathrm{CO}_{2}$ durante o processo de fotossíntese e respiração. $\mathrm{O}$ aumento da concentração de $\mathrm{CO}_{2}$ da atmosfera e as alterações do ciclo global do nitrogênio podem mudar a fisiologia do ecossistema, devido à relação dos ciclos de carbono e nitrogênio durante a decomposição e produção primária. Outro assunto global importante, associado com a mudança do uso da terra (agricultura e expansão da floresta) é a variabilidade interanual (fenômenos de El niño/La niña), que pode também ter efeitos substanciais, na escala do tempo e magnitude, na fotossíntese e respiração de um ecossistema (LAURANCE, 1998).

Nos últimos anos foram realizadas muitas pesquisas para avaliar e predizer os efeitos de aumento de $\mathrm{CO}_{2}$ nos ecossistemas. Porém, fortes preocupações têm sido expressadas, no sentido de que se podem ser preditas as respostas das plantas e dos ecossistemas a aumentos de níveis de $\mathrm{CO}_{2}$ unicamente com experimentos em curto prazo. Nas predições de aumento de $\mathrm{CO}_{2}$ devem ser considerados também experimentos com aumentos de $\mathrm{CO}_{2}$ em longo prazo (HÄTTENSCHWILER, 1998).

Em curto prazo, concentrações elevadas de $\mathrm{CO}_{2}$ da atmosfera tendem a estimular a fotossíntese das plantas, e melhorar o ingresso de carbono no ecossistema

\footnotetext{
* As plantas são denominadas de C3 ou C4 conforme seu metabolismo fotossintético.
} 
terrestre. Significativos progressos foram realizados na caracterização do impacto de elevadas concentrações de $\mathrm{CO}_{2}$ nos microorganismos do solo e nos processos microbianos. Mas, a informação que se tem são em experimentos em solos com distúrbios ou experimentos em curto prazo. Dados sobre a resposta microbiana, a elevadas concentrações de $\mathrm{CO}_{2}$, em longo prazo são também necessários, para identificar se a resposta observada nos dados de experimentos em curto prazo pode persistir indefinidamente (HU, et al., 1999).

\subsubsection{Protocolo de Kyoto}

Sob a Convenção das Nações Unidas sobre a Mudança de Clima (United Nations Framework Convention on Climate Change - UNFCCC), mais de 160 países estão comprometidos a preparar seu inventário nacional dos gases do efeito estufa, as fontes das emissões antropogênicas e os sumidouros para a remoção. A estrutura padrão para a elaboração do relatório do inventário dos gases do efeito estufa foi elaborada pelo Grupo Intergovernamental de Especialistas sobre a Mudança do Clima (Intergovernmental Panel on Climate Change - IPCC), Diretrizes para o inventário nacional dos gases do efeito estufa (Guidelines for National Greenhouse Gas Inventories). Essas diretrizes revisadas foram posteriormente adotadas em Kyoto (LIM, et al., 1999).

O Protocolo de Kyoto, resultado da reunião realizada naquela cidade, foi aprovado por mais de 150 nações em dezembro de 1997. Nele se estabeleceram compromissos internacionais para tentar reduzir emissões dos gases do efeito estufa para a atmosfera. Sob o Protocolo de Kyoto, algumas das emissões e remoções de carbono, mudanças do uso da terra e setor da silvicultura, podem ser contabilizadas como parte do compromisso dos países para a redução das emissões dos gases do efeito estufa. Além do impacto que as práticas do uso da terra têm nas emissões de $\mathrm{CO}_{2}$, a combustão de combustíveis fósseis e as mudanças no estoque de carbono nas florestas causadas pelas atividades humanas diretas tais como: florestamento, reflorestamento e desmatamento, são levadas em conta nesse protocolo (MARLAND e SCHLAMADINGER, 1999). 
O Protocolo de Kyoto invocou 38 países, com economia desenvolvida ou economia em transição, a reduzirem suas emissões líquidas de gases do efeito estufa em 5,2\%. Essa meta é definida pela comparação das emissões durante o período 2008 a 2012 com as emissões de 1990. A definição de emissões líquidas explicitamente leva em conta a captura de carbono pela expansão de sumidouros de carbono ou a liberação pela destruição de sumidouros. O Protocolo de Kyoto não impõe ações específicas para reduzir as emissões líquidas. As nações são livres para eleger políticas nacionais de mitigação de emissões (WALSH, 1999).

O Protocolo de Kyoto, para ser aceito, precisa ser ratificado pelos países desenvolvidos que representam no mínimo $55 \%$ das emissões de $\mathrm{CO}_{2}$ no planeta. Durante a Conferência Rio+10, realizada em Johannesburgo, a Rússia, o Canadá e a Polônia anunciaram que ratificarão o Protocolo. Esses países têm, respectivamente, $17,4 \%, 3,3 \%$ e $3,0 \%$ das emissões mundiais de gases causadores do efeito estufa. Somadas às quotas de outros países desenvolvidos, haveria um total de 60,8\%. Em resumo, a situação indica que o Protocolo de Kyoto entrará em vigor quando os parlamentos da Rússia, do Canadá e da Polônia o ratificarem.

Os Estados Unidos não aderiram ao Protocolo de Kyoto. O governo norte-americano considera que o crescimento econômico de seu país está acima da prioridade de Kyoto: evitar mudanças climáticas bruscas e, sobretudo, o aquecimento do planeta. As emissões de dióxido de carbono dos Estados Unidos nos próximos dez anos vão aumentar 12\%. O que significa produzir, em 2010, 35\% mais gases-estufa do que admite o Protocolo de Kyoto. O dióxido de carbono representa 76\% dos gases-estufa, e os signatários do Protocolo de Kyoto gostariam de vê-lo reduzido, até 2012, em 5,2\% (OESP, 2002).

\subsubsection{Créditos de carbono}

O artigo 12 do Protocolo de Kyoto estabelece o "Mecanismo de Desenvolvimento Limpo", o qual concede créditos de emissão dos gases do efeito estufa comercializáveis, para projetos que produzam "certificados de redução de 
emissões" nos países em desenvolvimento. Ou seja, os países desenvolvidos podem obter dos países em desenvolvimento "certificados de redução de emissões" e aplicar essas reduções para atingir seu compromisso de redução (LEBLANK, 1999, MARLAND e SCHLAMADINGER, 1999).

Através do comércio de emissões, os países são livres para realizar reduções extraordinárias de suas emissões e vender seus serviços de limpeza da atmosfera a outros países. Por outro lado, alternativamente, os países emissores estão habilitados para comprar a redução de emissões gerada por outros países, se é que este seja o caminho mais econômico para cumprir suas obrigações de redução. Se for planejado apropriadamente, o Mecanismo de Desenvolvimento Limpo pode tornar-se um sistema potente para promover tecnologias sustentáveis e melhorar os sumidouros de carbono nos países em desenvolvimento (WALSH, 1999).

No caso do Brasil, o emergente mercado do Mecanismo de Desenvolvimento Limpo é uma possibilidade concreta de adicionar valor e de remuneração extra não só aos produtores que utilizam plantio direto, mas uma extensa gama de atividades agrícolas. Na prática, o mercado de cotas de resgate de gases responsáveis pelo efeito estufa já é realidade e a própria Bolsa de Chicago tem cotação básica estimada de US\$10,00/t de carbono (RPD, 2000). 


\subsection{Estado da arte de modelos de fluxo e troca de $\mathrm{CO}_{2}$}

Em função da importância de se avaliarem os fluxos e a troca de carbono foram desenvolvidos diversos modelos para poder simulá-los e predizê-los, seja no nível global ou local. A seguir, é apresentada uma revisão da literatura sobre tais modelos.

Existem dois assuntos fundamentais para entender o metabolismo do carbono da Terra e o impacto da mudança global sobre este: a localização e intensidade das fontes e sumidouros do carbono contemporâneo, e a sua trajetória futura em função do clima, composição atmosférica e mudanças no uso da terra. Para direcionar estes dois assuntos-chave, uma aproximação multidisciplinar e integrada, que envolva monitoração em várias escalas espaciais, experimentação e modelagem, é requerida. Algumas aproximações são disponíveis para medir fluxos e concentrações de $\mathrm{CO}_{2}$ atmosférico em diversas escalas espaciais. Estes provêm informação sobre a localização das fontes e sumidouros de carbono nos continentes, regiões e ecossistemas (aproximação “top-down”). Por exemplo, os resultados da amostragem de gás de uma cadeia de lugares, combinados com modelos de transporte atmosférico global, provêm estimativas de fluxos de carbono, nas escalas continentais e subcontinentais. Uma análise mais detalhada do fluxo espacial pode ser obtida tomando medidas desde balões e aviões, os quais provêem informação do fluxo de regiões e paisagens. Torres de covariância Eddy podem identificar a contribuição dos vários componentes da paisagem, e prover informação detalhada sobre o controle do clima em cima dos fluxos de todo o ecossistema. Medidas de covariância Eddy em conjunção com os resultados dos estudos da fisiologia de um ecossistema podem prover uma percepção da contribuição relativa dos vários componentes de um ecossistema (solo, micróbios e dossel) e dos fluxos (respiração e fotossíntese), os quais são as bases para um entendimento mecanístico (aproximação "bottom-up") (CANADELL e MOONEY, 1999).

Além de entender a localização espacial e a intensidade das fontes e sumidouros de carbono, é crítico predizer as trajetórias e dinâmicas futuras dos 
fluxos de carbono. A resposta dos ecossistemas às variações climáticas anuais, ou tendências do clima em curto prazo, provavelmente dará uma indicação ambígua da trajetória futura dos fluxos de carbono, pois se ignora o ajuste metabólico em longo prazo e a retroalimentação biogeoquímica. Experimentos e observações em longo prazo (tais como aumento da concentração de $\mathrm{CO}_{2}$, aquecimento do solo e do ar, e alteração da deposição do nitrogênio), também são requeridos para prover dados que permitam o desenvolvimento e teste de modelos desses fenômenos, e assim prever fluxos de carbono sob cenários climáticos e atmosféricos futuros. A perspectiva topdown permite quantificar fluxos de carbono sobre a biosfera das escalas global, continental, regional e de paisagem. A aproximação bottom-up permite examinar as dinâmicas e mecanismos que controlam esses fluxos no nível de um ecossistema, e fornece dados necessários para o desenvolvimento e validação de modelos globais e de ecossistemas, os quais estimarão os fluxos futuros de carbono (CANADELL e MOONEY, 1999).

Nos últimos anos o interesse em modelos de produtividade primária líquida (Net Primary Produtiviry -NPP) de ecossistemas terrestres tem aumentado, devido à importância do ciclo de carbono terrestre na provisão do carbono global e nas mudanças de clima. Diversos modelos de processos de produtividade primária líquida têm sido desenvolvidos para este propósito. Alguns modelos são executados em degraus de tempo curto (minutos a horas) e resoluções espaciais grossas $\left(2^{\circ}-5^{\circ}\right)$, e em conjunção com modelos de circulação geral (GCM). Outros modelos são executados com resoluções espaciais moderadas $(1 \mathrm{~km})$ e degraus de tempo longo, desde dias até meses, usando dados medidos remotamente ou outros dados. Para aplicações regional e global, os modeladores usualmente têm que enfrentar a escolha entre as resoluções temporais e espaciais, e as metodologias de modelagem podem ser muito diferentes para estas duas escolhas. Os modelos, com degraus de hora e degraus menores que uma hora, usualmente consideram cada degrau como instantâneo, e nenhuma integração temporal é realizada; tais modelos sofrem de inexatidão no escalamento espacial. A heterogeneidade da superfície terrestre faz tal escalamento um desafio considerável. Com o uso de modelos de degraus de dias ou meses, a resolução espacial pode ser melhorada e os erros devido ao escalamento 
espacial podem ser reduzidos. Contudo, muitos detalhes dos processos do dossel não podem ser simulados em degraus de tempo longo, e os modelos têm se tornado mais empíricos à medida que aumentam os degraus de tempo na modelagem (CHEN, et al., 1999).

Nas décadas passadas, os processos ecofisiológicos, tais como fotossíntese, condutância dos estômatos, e balanço de energia foliar, têm sido relativamente bem compreendidos, e modelos mecanísticos de troca de gás têm sido desenvolvidos e verificados na escala da folha. Um maior desafio é ampliar efetivamente este entendimento da escala da folha para dimensões de uma floresta. Como o escalamento envolve integração de processos tanto espacial como temporal, e diferentes aproximações, por exemplo "folha - grande" ou multilayer, o grau com o qual os modelos existentes representam o conhecimento fisiológico da planta varia amplamente. Por outro lado, como as medidas in situ dos fluxos micrometeorológicos ou dos processos fisiológicos da folha são insuficientes, e eles são usados para parametrizar os cálculos dos modelos, a maioria dos modelos não tem sido testada amplamente com as medidas de campo de troca de massa e energia e também são poucos os testes sobre diversos tipos de vegetação (KELLOMÄKI e WANG, 2000).

Quando a intenção dos modeladores é ganhar percepção dos mecanismos que governam a troca de gás dentro de um dossel, a aproximação up-scaling, usando o modelo multilayer, parece ser a mais apropriada, enquanto aproximações top-down, usando os modelos chamados "folha - grande", são provavelmente as mais escolhidas para propósitos de predição, especialmente a grande escala, onde a precisão reduzida é compensada pela eficiência computacional. Up-scaling refere-se a usar informação de uma escala, espacial ou temporal, para deduzir características em outra escala. Escalar, up-scaling, a troca de gás das folhas para toda a planta, significa que as informações na escala da folha (área foliar, e características de troca de gás) são combinadas com as forças motrizes do ambiente que conduzem a troca de gás dentro do dossel, para quantificar os fluxos de $\mathrm{CO}_{2}$ e $\mathrm{H}_{2} \mathrm{O}$ de toda a planta. 
Portanto, a base para uma aproximação up-scaling é um modelo de fotossíntese e condutância estomática na escala da folha (WOHLFAHRT, et al., 2000).

FARQUHAR e VON CAEMMERER, (1980), apud (INFANTE, et al., 1999), desenvolveram um modelo mecanístico de assimilação de $\mathrm{CO}_{2}$ da folha, em plantas tipo C3, o qual tem sido usado como ponto de partida em muitas simulações de fotossíntese da folha em diferentes espécies. Contudo, ainda não foi desenvolvido nenhum modelo mecanístico para a condutância estomática. Freqüentemente, o modelo de fotossíntese de Farquhar tem sido unido a modelos empíricos de condutância estomática.

Um modelo de assimilação de $\mathrm{CO}_{2}$ mecanístico, para folhas tipo $\mathrm{C} 3$, unido a um modelo empírico do estômato, é apresentado para simular a fotossíntese líquida da folha Quercus ilex do ecossistema oak-savannah, no Sul da Espanha. O modelo estima (integração temporal) mudanças diárias e temporais de fixação de carbono, transpiração e uso eficiente da água de uma única folha no ar livre (INFANTE, et al., 1999).

WOHLFAHRT, et al., (2000) apresentam um modelo que quantifica a troca de gás de $\mathrm{CO}_{2}$ e $\mathrm{H}_{2} \mathrm{O}$ de toda planta, em seu microambiente natural, o dossel. Numa aproximação up-scaling o modelo combina simulações na escala da folha (troca de gás, balanço de energia) e na escala do dossel (transferência de radiação, atenuação do vento). Para a troca de gás na folha, a fotossíntese líquida e a condutância do estômato são modeladas usando um modelo sensível ao nitrogênio. A transferência de radiação é simulada separadamente das faixas de onda de radiação ativa fotossintética, próximo do infravermelho e da radiação de onda longa, por meio de um modelo que considera uma dispersão de radiação múltipla e usa informação detalhada da estrutura do dossel como dados de entrada.

$\mathrm{O}$ efeito de dobrar a concentração de $\mathrm{CO}_{2}$ atmosférico sobre o clima e a vegetação é pesquisado usando um modelo combinado clima-vegetação. O modelo de vegetação prediz as respostas de índice de área foliar, transpiração do dossel e 
balanço de carbono em toda a planta, para mudanças no clima, umidade do solo e $\mathrm{CO}_{2}$ atmosférico. $\mathrm{O}$ modelo usa uma aproximação otimizada para predizer a resistência do estômato, um modelo bioquímico prediz a fotossíntese, e um modelo de balanço de carbono simples prediz a área foliar (FRIEND e COX, 1995).

Um modelo matemático que prediz o efeito do ozônio $\left(\mathrm{O}_{3}\right)$ do ambiente sobre a taxa fotossintética de Quercus mongolica foi desenvolvido para uma floresta efêmera e temperada, tanto para uma área urbana como para uma área de referência, na Coréia. $\mathrm{O}$ padrão diário da concentração de $\mathrm{O}_{3}$, média de cada hora, monitorado no lugar de estudo, foi simulado usando a equação Gaussiana. Os efeitos, em curto prazo, de $\mathrm{O}_{3}$ sobre a taxa de fotossíntese foram estimados usando a relação entre a concentração de $\mathrm{O}_{3}$ do ambiente e a redução percentual da fotossíntese líquida (WOOK e KIM, 1997).

Devido a que o modelo de Farquhar é unicamente aplicável a folhas individuais, instantaneamente, considerável perícia é necessária para usar este modelo na estimação regional do crescimento da planta e na provisão do carbono. Em muitos modelos publicados, as equações de Farquhar foram aplicadas diretamente ao dossel das plantas assumindo que o dossel das plantas funciona como uma "folha grande". Esta aproximação é aceitável para estimar tendências temporais da fotossíntese do dossel, mas inadequada para simular variações diárias. Isto é observado ao se comparar com medidas de covariância Eddy e medidas de troca de gás numa câmara, em duas florestas boreais. A variação diária é afetada grandemente nas simulações de "folha grande" porque o modelo original, no nível da folha, é parcialmente modificado ao se substituir a condutância do estômato pela condutância do dossel. Aproximações alternativas, tais como separação do dossel em grupos de folhas iluminadas pelo sol e folhas à sombra, ou estratificando o dossel em múltiplas camadas, podem evitar o problema. Devido à resposta não linear da fotossíntese da folha a variáveis meteorológicas (radiação, temperatura e umidade), existem consideráveis erros no cálculo diário da fotossíntese, sem considerar a variabilidade diária das variáveis (CHEN, et al., 1999). 
Fluxos de vapor de água e $\mathrm{CO}_{2}$, do dossel de cultivo de sparse millet, foram simulados usando um modelo para a escala da folha, projetado para predizer diariamente a condutância do estômato, temperatura da folha, taxa de transpiração e taxa de fotossíntese para millet. Os fluxos modelados na escala da folha foram extrapolados usando duas aproximações de "folha grande" diferentes. $\mathrm{Na}$ aproximação de "folha grande" tradicional, todas as folhas são expostas ao mesmo microambiente, o qual difere das condições ambientais acima do dossel, enquanto que na aproximação de "folha grande" modificada considera-se que uma parte da "folha grande" é exposta à sombra. No modelo de "folha grande com sol e sombra", a reflexão do solo, a radiação difusa e a avaliação separada da carga de radiação sobre a superfície das folhas expostas à luz do sol e à sombra são consideradas. Devido a que as folhas expostas à sombra são uma fração baixa num dossel não denso, os dois tipos de modelos de "folha grande" predizem os fluxos do dossel igualmente bem (BOEGH, et al., 1999).

Em KELLOMÄKI e WANG, (2000) medidas de fluxo de $\mathrm{CO}_{2}$ com a técnica de covariância Eddy foram unidas a medidas detalhadas do solo e do microclima, as quais foram realizadas numa floresta boreal de pinheiros não perturbada, para entender os efeitos da variação de curto prazo sobre os fluxos de $\mathrm{CO}_{2}$ diários no dossel. Ou seja, procurou-se entender o papel que cumprem as variáveis fisiológicas e ambientais em curto prazo (na escala de tempo de horas) sobre os fluxos de $\mathrm{CO}_{2}$ de todo o ecossistema, para testar se o conhecimento atual dos processos, na escala da folha, é suficiente para entender a troca de $\mathrm{CO}_{2}$ na escala de estande. Um modelo parametrizado de fluxo de carbono no dossel é apresentado, no qual o escalamento de troca de $\mathrm{CO}_{2}$ da folha para o dossel é alcançado, integrando modelos mecanísticos de processos fisiológicos (fotossíntese, condutância do estômato e respiração dos componentes do ecossistema) e processos micrometeorológicos (transferência de radiação, transferência de turbulência e troca de energia na superfície).

Nos últimos anos, um maior esforço tem sido realizado para modelar fluxos de carbono e água na escala de estande instantaneamente. Tanto aproximações topdown como bottom-up são usadas para modelar fluxos de ecossistemas florestais em 
curto prazo. Diversos modelos fisiológicos usam o conhecimento acerca das respostas fotossintéticas e dos estômatos no nível da folha, e escalam estes para o nível do dossel usando elaborados modelos de intercepção de radiação. Com esses modelos detalhados são prognosticados fluxos de água e carbono. Modelos para predizer fluxos de água e carbono instantâneos, em ecossistemas florestais, são usualmente desenvolvidos, calibrados e validados para uma floresta específica. Para cada aplicação específica, parâmetros das funções de resposta são otimizados, ou informação fisiológica detalhada para cada espécie é usada. Extrapolar para outros locais de floresta, nesses casos, é difícil e consome tempo (VAN WIJK e BOUTEN, 1999).

Redes neurais artificiais são estruturas de mapeamento não linear, baseados na função do cérebro humano. Elas têm mostrado que podem fazer aproximações de funções altamente flexíveis e universais, o que os torna uma ferramenta poderosa para modelos. As redes neurais artificiais foram inicialmente desenvolvidas para modelar funções biológicas, e nas últimas décadas, pesquisas em redes neurais têm mostrado um crescimento explosivo. Freqüentemente são aplicadas em pesquisa física como reconhecimento de voz e reconhecimento de imagens, e em pesquisa química como reconhecimento de odores (BARATTO, 1998; BARATTO, et al., 1998; PUENTE DE LA VEGA, et al. 1999). No campo da biologia, as aplicações de redes neurais têm sido na medicina e biologia molecular. Contudo, algumas aplicações deste método foram reportadas em ciência ambiental e ecologia, no começo da década do 90 (BASHEER e HAJMEER, 2000; GROSS, et al., 1999; LEK e GUÉGAN, 1999).

Redes neurais artificiais foram usadas para modelar a troca de vapor de água e carbono em ecossistemas florestais de coníferas, com um conjunto mínimo de variáveis de entrada, independentemente das espécies de árvores e sem informação fisiológica detalhada. Radiação, temperatura, déficit de pressão de vapor e tempo do dia mostraram ser variáveis de entrada dinâmicas que determinam os fluxos de água do ecossistema. As mesmas variáveis, junto com o índice de área foliar projetado, 
foram necessárias para a modelagem de fluxos de $\mathrm{CO}_{2}$. (VAN WIJK e BOUTEN, 1999).

Um mapeamento não linear geral entre as variáveis ambientais, $\mathrm{X}_{\mathrm{j}}$, e a condutância do estômato, $\mathrm{g}_{\mathrm{s}}$, foi encontrado, usando redes neurais artificiais, com algoritmo de treinamento "backpropagation". Redes neurais deste tipo são aptas para reproduzir qualquer função não linear "razoável", fornecendo-lhe dados de "treinamento" suficientemente exatos. A aproximação por meio da rede permite um melhor ajuste do modelo para $\mathrm{g}_{\mathrm{s}}$, sem requerer uma definição separada da forma da função para cada variável ambiental. Ao contrário, a rede neural produz uma forma de $g_{s}$ que não pode ser separada dentro de dependências distintas para cada entrada. Como tal, a função derivada da rede pode ser vista como um ajuste não linear "não constrangido", o qual provê um ponto de referência que pode ser comparado com modelos de $g_{s}$ baseados na física (HUNTINGFORD e COX, 1997).

Outro método que está sendo bastante utilizado em modelos de processos industriais e químicos e que tem um potencial a ser explorado em pesquisas ecológicas é a lógica fuzzy.

A quantificação do impacto ecológico devido à atividade humana é difícil. Freqüentemente existem diferentes indicadores que podem entrar em conflito uns com os outros, continuamente faltam observações importantes, e informações de valor potencial podem não ser quantitativas na natureza. A teoria de conjuntos fuzzy oferece uma metodologia para lidar com esses problemas e provê uma aproximação útil para problemas de classificação difíceis. Uma importante característica dos conjuntos fuzzy é que eles provêm um formalismo de incorporar ambigüidade e falta de dados quantitativos num esquema de classificação. Isto não impede a possibilidade de usar conjuntos fuzzy para prover degraus numéricos precisos se estes são necessários para necessidades legais ou outras razões. O processo de ir dos conjuntos fuzzy para índices quantitativos, o qual é chamado de defuzzificação, pode ser levado separadamente da análise fuzzy e não conflitar com os processos de coleta e classificação de dados (SILVERT, 1997). 
Um método estocástico para a simulação de florestas, baseado na variação de métodos de atributos vitais e teoria de sistemas fuzzy, foi desenvolvido para investigar a estrutura e composição da floresta em regime de fogo. Atributos vitais são características de espécies individuais com relação ao meio ambiente consistindo em: métodos de reprodução, idade da primeira reprodução, longevidade, tolerância à sombra e resistência à degradação (fogo). Numa simulação de uma floresta de coníferas, no sudoeste dos Estados Unidos, foi determinado que essas características são suficientes para modelar o comportamento da vegetação da floresta sujeita a transtornos periódicos com intervalo de retorno diverso e severo (ROBERTS, 1996a).

A modelagem da paisagem da vegetação é uma aproximação à modelagem para simular a dinâmica de uma paisagem. Foi desenvolvido um modelo para simular os mecanismos ecológicos explícitos espacialmente, baseado em trabalhos prévios de teoria de atributos vitais e teoria de sistemas fuzzy (ROBERTS, 1996b). 


\section{FUNDAMENTO TEÓRICO}

Neste capítulo será apresentada uma breve revisão acerca dos conceitos teóricos básicos de ecofisiologia vegetal (item 3.1) e redes neurais artificiais (item 3.2). No item 3.1 tratar-se-á sobre conceitos de troca de gás nas plantas, estômato, transpiração e fotossíntese. No item 3.2 apresentar-se-ão conceitos sobre neurônio biológico, neurônio artificial, redes neurais artificiais, redes MLP (Multilayer Perceptron) com algoritmo de treinamento backpropagation, e aplicação das redes neurais artificiais.

\subsection{Conceitos básicos de ecofisiologia vegetal}

O item 3.1.1 foi extraído de LARCHER, (1995), os itens 3.1.2 e 3.1.3 de RAVEN, et al., (1992), e o item 3.1.4 de LOUREIRO, et al., (2002).

\subsubsection{Troca de gás nas plantas}

O metabolismo do carbono nas células está ligado com a atmosfera pela troca de gás. Isto implica a troca de $\mathrm{CO}_{2}$ e $\mathrm{O}_{2}$ entre o interior da planta e seu entorno. $\mathrm{Na}$ troca de gás fotossintética a planta toma $\mathrm{CO}_{2}$ e libera $\mathrm{O}_{2}$, enquanto que na troca de gás respiratória a direção do transporte dos dois gases é inversa. A troca de gás entre as células e o ambiente da planta se dá por difusão e fluxo de massa. Por cada grama de glicose formada $1,47 \mathrm{~g}$ de $\mathrm{CO}_{2}$ é requerido, que é aproximadamente a quantidade contida em 2500 litros de ar.

Em seu caminho ao cloroplasto o $\mathrm{CO}_{2}$ encontra uma série de obstáculos. Como ilustração, na Figura 3.1 são mostrados os caminhos do transporte do gás e as resistências de transferência sobre e dentro da folha. Perto da superfície da folha a troca de gás é lenta. A resistência da camada circundante $\left(r_{a}\right)$ é particularmente alta se uma camada estacionária de ar forma-se sobre a superfície da folha. O primeiro 
meio de entrada para o transporte do gás é o estômato. Quando o estômato está totalmente aberto a resistência de difusão do estômato $\left(\mathrm{r}_{\mathrm{s}}\right)$ tem um valor específico mínimo, dependendo do tamanho e densidade do estômato; quando o estômato está fechado $r_{s}$ é aproximadamente infinito. As resistências internas para a transferência de $\mathrm{CO}_{2}$, chamada também resistência residual $\left(\mathrm{r}_{\mathrm{r}}\right)$, são formadas pelas resistências encontradas na entrada da fase líquida da célula, pela resistência de carboxilação (carboxylatio) $\left(\mathrm{r}_{\mathrm{cx}}\right)$ e pela resistência de excitação $\left(\mathrm{r}_{\mathrm{exc}}\right)$.

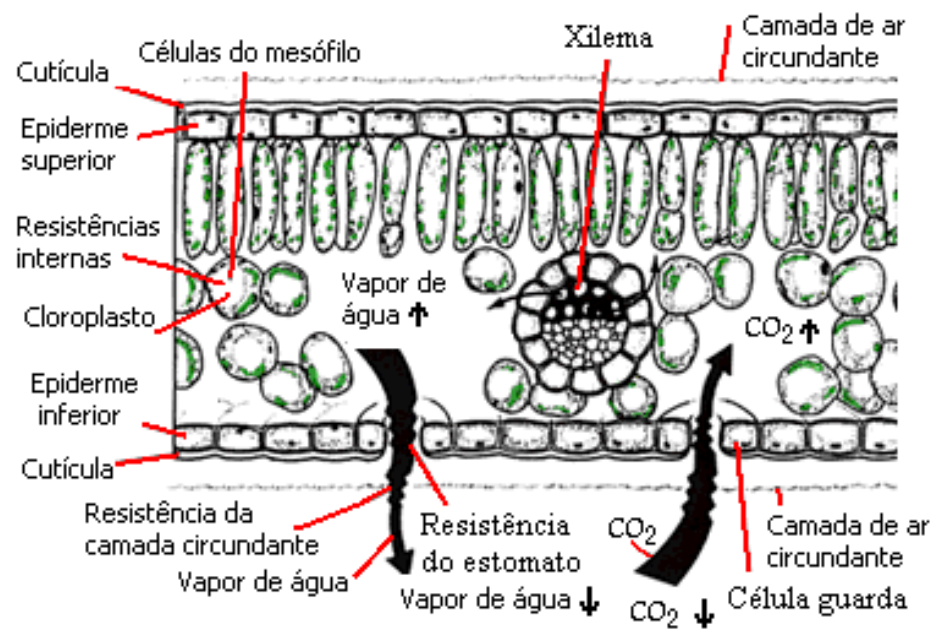

Figura 3.1 Troca de gás na folha*.

\subsubsection{Estômato}

Os estômatos são aberturas pequenas na epiderme, cada uma rodeada por duas células-guarda, as quais podem mudar sua forma para efetuar o fechamento e a abertura dos poros (Figura 3.2). Os estômatos controlam a entrada e saída de $\mathrm{CO}_{2} \mathrm{e}$ vapor de água na folha variando a largura dos poros (Figura 3.1).

As células-guarda estão continuamente em movimento com os poros se estreitando e alargando. O número, a distribuição, o tamanho, a forma e a mobilidade do estômato são características especificas de cada espécie.

\footnotetext{
* Figura disponível em URL: http://www.treebiol.forest.wisc.edu/forestry415/leture6/lfexcont.htm [Acesso em 30/06/03].
} 
A dimensão crítica que determina a resistência estomática $\left(\mathrm{r}_{\mathrm{s}}\right)$ é a largura do poro. A resistência de difusão do estômato aumenta exponencialmente com a diminuição da largura do poro, de acordo com uma função hiperbólica. Sua recíproca $\left(1 / r_{s}\right)$, é a condutância estomática $\left(g_{s}\right)$, a qual é diretamente proporcional à largura do poro.

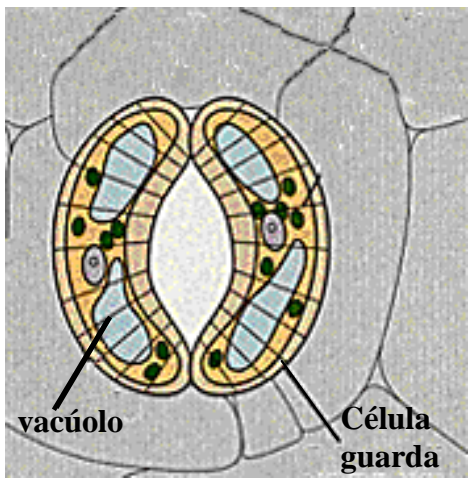

a) Célula túrgida/ estômato aberto

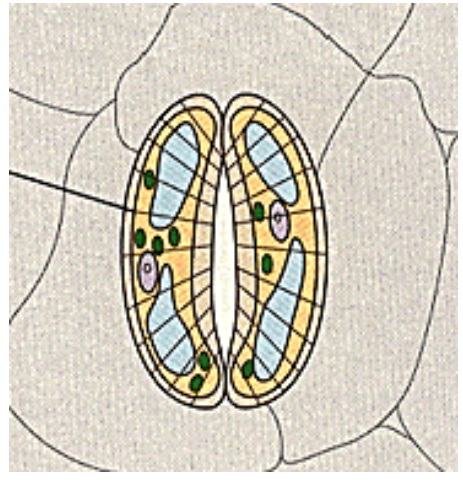

b) Célula flácida/ estômato fechado

Figura 3.2 Representação esquemática do estômato, (a) estômato aberto (b) estômato fechado*.

\subsubsection{Fatores que afetam a abertura e o fechamento dos estômatos}

A abertura e o fechamento dos estômatos são afetados por vários fatores ambientais (movimento dos estômatos), sendo a perda de água o de maior influência. Quando o turgor da folha cai abaixo de certo ponto crítico (variável para cada espécie) a abertura do estômato é menor. $\mathrm{O}$ fator que predomina sobre os demais fatores que afetam o estômato é a perda de água, mas mudanças nos estômatos podem ocorrer independentemente do ganho ou perda total de água pela planta. Outros fatores ambientais que afetam o movimento dos estômatos são a concentração de dióxido de carbono, luz e temperatura. Em muitas espécies, um aumento na concentração de $\mathrm{CO}_{2}$ ocasiona o fechamento do estômato. A amplitude dessa resposta ao $\mathrm{CO}_{2}$ varia de espécie para espécie e com o grau de estresse hídrico a que a planta é submetida.

\footnotetext{
* Figura disponível em URL: http://www.treebiol.forest.wisc.edu/forestry415/leture6/stomate.htm [Acesso em 30/06/03].
} 
O estômato se abre em presença de luz e fecha no escuro, na maioria das espécies. Isto pode ser explicado em parte pela utilização fotossintética de $\mathrm{CO}_{2}$, que leva à redução no nível de $\mathrm{CO}_{2}$ dentro da folha.

Variações de temperatura têm pouco efeito no comportamento dos estômatos, dentro das faixas normais $\left(10^{\circ} \mathrm{C}-25^{\circ} \mathrm{C}\right)$, mas temperaturas maiores que $30^{\circ} \mathrm{C}-35^{\circ} \mathrm{C}$ podem levar ao fechamento dos estômatos. Contudo, o fechamento se pode prevenir mantendo a planta num ambiente isento de $\mathrm{CO}_{2}$, o que indica que variações na temperatura atuariam primariamente afetando a concentração de $\mathrm{CO}_{2}$ na folha. A causa real do fechamento estomático em resposta ao aquecimento pode ser um aumento na temperatura que resulta em um aumento da respiração e em um aumento concomitante da concentração intercelular de $\mathrm{CO}_{2}$. Em climas quentes muitas plantas fecham seus estômatos regularmente ao meio-dia, devido aparentemente ao efeito da temperatura sobre o acúmulo de $\mathrm{CO}_{2}$ e devido à desidratação das folhas, à medida que a perda de água pela transpiração excede o ganho de água pela absorção. Os estômatos não respondem apenas a fatores ambientais, eles também mostram ritmos diários de abertura e fechamento que parecem ser controlados pela própria planta.

Na maioria das plantas os estômatos estão abertos durante o dia e fechados à noite, mas isto não ocorre em todas as plantas.

\subsubsection{Transpiração}

A transpiração é o principal fator que determina o movimento da água através da planta. A transpiração é o processo através do qual as plantas liberam para o ar aproximadamente $99 \%$ da água absorvida pelas raízes como vapor de água. Este processo pode envolver qualquer parte do organismo vegetal acima do solo; entretanto, as folhas são os principais órgãos da transpiração.

A perda de quantidades grandes de água na transpiração está relacionada com a fotossíntese, a fonte de todo alimento para a planta. A energia necessária para a fotossíntese vem da luz solar. Para realizar fotossíntese máxima, a planta deve expor 
o máximo de sua superfície ao sol, o que cria ao mesmo tempo uma grande superfície de transpiração; mas além da luz solar outro dos requisitos é que os cloroplastos também precisam de dióxido de carbono. Na maioria dos casos, o dióxido de carbono está facilmente disponível no ambiente da planta, mas para o dióxido de carbono penetrar na célula vegetal, o que se dá por difusão, deve estar em solução, pois a membrana plasmática é praticamente impermeável à forma gasosa do dióxido de carbono. Por isso, o gás deve entrar em contato com uma superfície celular úmida. Mas, sempre que a água entra em contato com o ar, ocorre evaporação. Ou seja, a captação de dióxido de carbono para a fotossíntese e a perda de água pela transpiração estão ligadas de forma complexa na vida de uma planta.

\subsubsection{Controle da transpiração}

As folhas estão recobertas por uma cutícula impermeável tanto à água quanto ao dióxido de carbono. Somente uma pequena fração da água perdida pela transpiração sai através deste revestimento protetor, e outra pequena fração é perdida através das lenticelas* na casca. A maior parte da água perdida pela transpiração nas plantas vasculares se dá através dos estômatos. A transpiração estomática envolve duas etapas: (1) a evaporação da água das superfícies das paredes celulares adjacentes aos espaços intercelulares, e (2) a difusão do vapor de água resultante das paredes intercelulares para a atmosfera através dos estômatos.

O fechamento dos estômatos impede a perda de vapor de água pela folha, mas isso impede a entrada de dióxido de carbono. Uma certa quantidade de dióxido de carbono, contudo, é produzida pela planta durante a respiração, e com a disponibilidade de luz este dióxido de carbono pode ser utilizado para a manutenção de um nível muito baixo de fotossíntese mesmo quando os estômatos estão fechados.

\footnotetext{
* Lenticela: pequena abertura na periderme das plantas lenhosas que permite as trocas gasosas.
} 


\subsubsection{Fatores que afetam a taxa de transpiração}

Apesar de a abertura e o fechamento dos estômatos serem os fatores que mais afetam a taxa de transpiração, outros fatores, tanto ambientais assim como da própria planta, influem na transpiração. Um dos mais importantes é a temperatura. A velocidade de evaporação da água dobra a cada aumento de $10^{\circ} \mathrm{C}$ na temperatura. Mas, como a evaporação resfria a superfície foliar, sua temperatura não se eleva tão rapidamente como a do ar circundante. Como já mencionado, os estômatos fecham quando as temperaturas excedem $30^{\circ} \mathrm{C}-35^{\circ} \mathrm{C}$.

Outro fator importante é a umidade. A água é perdida muito mais lentamente numa atmosfera já saturada com vapor de água. As plantas que crescem em florestas sombreadas, onde a umidade é geralmente alta, tipicamente apresentam grandes superfícies foliares, pois o seu principal problema é obter luz suficiente e não perder a água. Em contraste, plantas de áreas expostas freqüentemente à luz possuem folhas estreitas caracterizadas por uma superfície relativamente pequena. Essas plantas obtêm toda a luz que necessitam, mas estão em constante risco de perda excessiva de água.

\subsubsection{Fotossíntese}

A fotossíntese pode ser considerada a principal rota biossintética da vida no planeta Terra. Em um ano, cerca de 7 x $10^{9}$ toneladas de carbono são fixados em compostos orgânicos. Isto equivale a $1 \%$ das reservas conhecidas de combustíveis fósseis (carvão, gás e petróleo) e cerca de 10 vezes o consumo mundial de energia. Por meio da fotossíntese, as plantas, algas e alguns tipos de bactérias convertem a energia física da luz solar em energia química. Essa energia é então armazenada nos compostos orgânicos presentes nas plantas, e serve como elo fundamental na manutenção de outras cadeias alimentares. 
A fotossíntese pode ser definida como um processo físico-químico, mediante o qual os organismos fotossintéticos sintetizam compostos orgânicos a partir de matéria-prima inorgânica, na presença de luz solar. Ela pode ser dividida em duas fases: a fase fotoquímica, na qual a energia luminosa é utilizada, gerando ATP (Adenosine triphosphate) e NADPH (Nicotinamide adenine dinucleotide phosphate), os quais serão então utilizados na segunda fase, a fase de fixação de $\mathrm{CO}_{2}$ (Figura 3.3). O processo fotossintético das plantas ocorre nos cloroplastos e resulta na liberação de oxigênio molecular e na captura de dióxido de carbono da atmosfera, que é utilizado para sintetizar carboidratos.

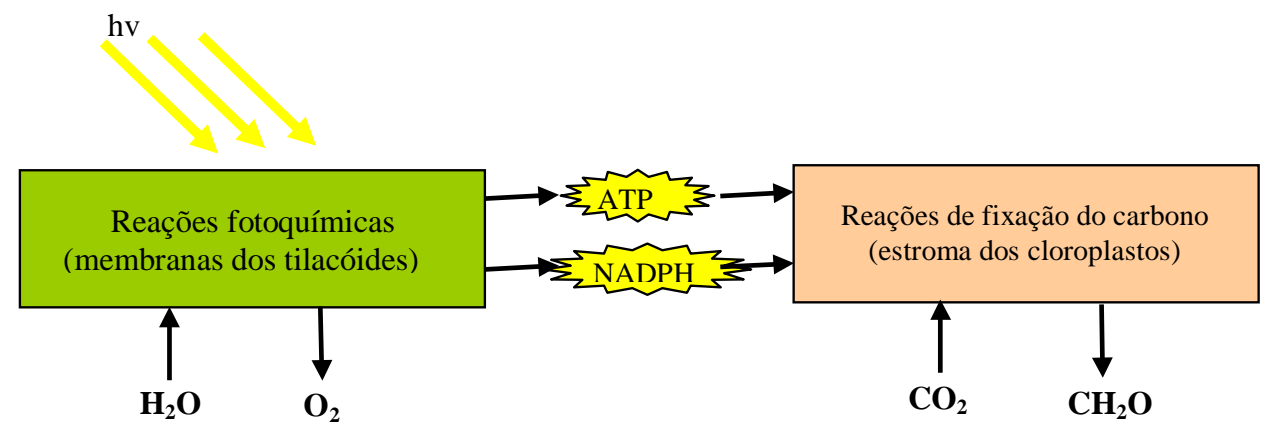

Figura 3.3 Fases da fotossíntese (LOUREIRO, et al., 2003).

A fotossíntese pode ser representada pela seguinte equação:

$$
n \mathrm{CO}_{2}+2 \mathrm{nH}_{2} \mathrm{O}+\text { Energia luminosa } \Rightarrow\left(\mathrm{CH}_{2} \mathrm{O}\right) n+n \mathrm{O}_{2}+\mathrm{nH}_{2} \mathrm{O}
$$

A síntese de carboidratos $\left(\left(\mathrm{CH}_{2} \mathrm{O}\right) n\right)$ a partir de dióxido de carbono e água requer um grande consumo de energia. A energia livre para a redução de um mol de $\mathrm{CO}_{2}$ até o nível de glicose é de $478 \mathrm{~kJ}$ mol-1, sendo utilizada energia luminosa para promover essa reação.

\subsubsection{A luz como fonte primária de energia}

A luz, fonte primária de energia na fotossíntese, é parte da radiação eletromagnética que é visível ao olho humano. A "luz visível” tem comprimentos de onda que vão do violeta, com cerca de $380 \mathrm{~nm}$, ao vermelho, com $700 \mathrm{~nm}$. Essa faixa 
do espectro de radiação eletromagnética também é chamada "radiação fotossintética ativa" (PAR - Photosynthetic Activity Radiation) (Figura 3.4). A luz possui características de uma partícula (fóton) e de uma onda eletromagnética. Assim a luz é uma corrente de partículas carregando energia, a qual é designada quanta. Cada quantum de luz, ou fóton, contém uma quantidade de energia, descrita pela equação:

$$
E=h c / \lambda
$$

Onde $E$ é a energia, $h$ a constante de Plank, $c$ a velocidade da luz e $\lambda$ o comprimento de onda.

Assim, nem todas as "cores" da luz (comprimento de onda) possuem a mesma energia, pois o nível energético de um fóton é inversamente proporcional a seu comprimento de onda.

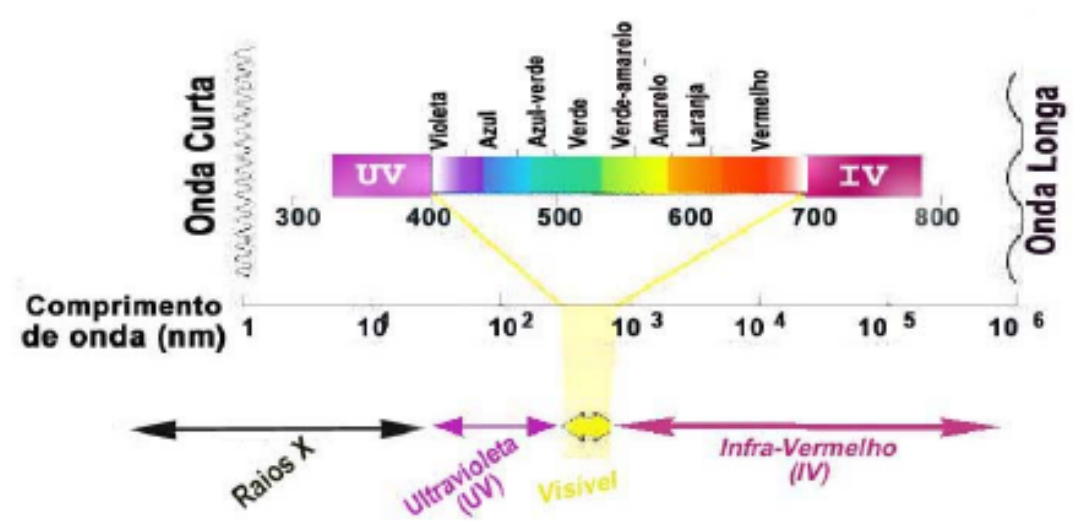

Figura 3.4 Características das várias regiões de comprimento de onda da luz (LOUREIRO, et al., 2003).

\subsubsection{Pigmentos fotossintéticos}

Para que a energia da luz possa ser utilizada na fotossíntese, ela primeiro precisa ser absorvida. Moléculas que absorvem luz são chamadas de pigmentos, e pigmentos fotossintéticos são aqueles pigmentos localizados no cloroplasto, especificamente associados à membrana dos tilacóides, os quais captam a energia da 
luz e permitem a sua utilização. As clorofilas (a e b) são os principais pigmentos fotossintéticos. Carotenóides também são pigmentos fotossintéticos, embora com uma função acessória à das clorofilas.

As clorofilas são os pigmentos que dão às plantas a sua cor verde característica. A clorofila a é verde azulada e a b é verde amarelada. Os máximos de absorção (comprimentos de onda correspondente a um pico na curva de absorção de luz) da clorofila a são 420 e $660 \mathrm{~nm}$ nas regiões azul e vermelho, respectivamente. Os máximos de absorção da clorofila b correspondem, respectivamente, a 435 e $643 \mathrm{~nm}$ nas regiões azul e vermelho.

Quando os pigmentos absorvem a luz, os elétrons são temporariamente impulsionados a um nível de energia mais alto. Quando os elétrons retornam para o nível mais baixo de energia, podem ocorrer três resultados possíveis: 1) a energia pode ser dissipada como calor; 2) a energia pode ser reemitida quase que instantaneamente como energia luminosa de comprimento de onda mais longo, um fenômeno conhecido como fluorescência; ou 3) a energia pode ser capturada para a formação de ligações químicas, como ocorre na fotossíntese.

\subsubsection{Cloroplastos}

Nas plantas, o processo fotossintético ocorre dentro dos cloroplastos, que são plastídios* localizados em células especializadas das folhas (células do mesófilo palissádico e do mesófilo lacunoso). O número de cloroplastos por célula varia de um a mais de cem, dependendo do tipo de planta e das condições de crescimento. Os cloroplastos (Figura 3.5) têm forma discóide com diâmetro de 5 a 10 micrômetros, limitados por uma dupla membrana (externa e interna). A membrana interna atua como uma barreira controlando o fluxo de moléculas orgânicas e íons dentro e fora do cloroplasto. Moléculas pequenas como $\mathrm{CO}_{2}, \mathrm{O}_{2}$ e $\mathrm{H}_{2} \mathrm{O}$ passam livremente através das membranas do cloroplasto.

\footnotetext{
* Plastídio: designação de qualquer estrutura especializada da célula, exceto o núcleo e o centrossomo.
} 
Internamente, o cloroplasto é composto de membranas, conhecidas como membranas fotossintéticas (ou membranas tilacoidais ou lamelas), que contêm a maioria das proteínas necessárias para a etapa fotoquímica da fotossíntese. As proteínas requeridas para a fixação e redução do $\mathrm{CO}_{2}$ estão localizadas na matriz incolor chamada estroma. As membranas tilacoidais formam os tilacóides, que são vesículas achatadas com um espaço interno aquoso chamado lúmen. Os tilacóides, em certas regiões, se dispõem em pilhas chamadas de grana (granum).

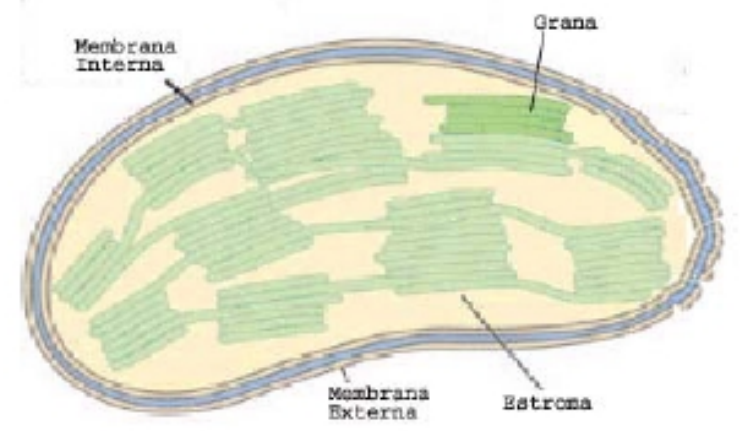

Figura 3.5 Estrutura do cloroplasto (LOUREIRO, et al., 2003).

\subsubsection{Fatores que afetam a fotossíntese}

Como foi visto no item 3.1.2 a abertura e o fechamento dos estômatos é um fator que afeta a fotossíntese; além deste outros fatores influenciam na fotossíntese. Os principais fatores ambientais que afetam a fotossíntese são a luz, a disponibilidade de $\mathrm{CO}_{2}$, a temperatura, a água no solo, os nutrientes, as condições patológicas e os poluentes, além desses influem fatores da própria planta, tais como modo de assimilação do carbono (plantas tipo C3, C4), a idade e a morfologia da folha, o índice de área foliar, o ângulo e a orientação da folha.

A fotossíntese depende do número de fótons absorvidos. A densidade do fluxo fotônico (DFF) expressa a quantidade de fótons (mol ou $\mu \mathrm{mol}$ de fótons) por unidade de área e de tempo. Num dia a pleno sol, a DFF, na faixa de radiação fotossintética ativa (400 a $700 \mathrm{~nm}$ ), pode alcançar valores de 2000 ou $2500 \mu \mathrm{mol} \mathrm{m} \mathrm{m}^{-2} \cdot \mathrm{s}^{-1}$. 
Considerando-se a absorção líquida de $\mathrm{CO}_{2}$ pela planta, dois processos antagônicos ocorrem nas plantas. De um lado, ocorre a absorção de $\mathrm{CO}_{2}$ pela planta através da fotossíntese. De outro lado, dois outros processos metabólicos liberam $\mathrm{CO}_{2}$ : a respiração mitocondrial e a fotorrespiração. Assim, a fotossíntese líquida pode ser definida pela seguinte equação:

$$
F_{N}=F_{B}-\left(R_{M}+F_{R}\right)
$$

Sendo $F_{N}$ a fotossíntese líquida, $F_{B}$ a fotossíntese bruta, $R_{M}$ a respiração mitocondrial e $\mathrm{F}_{\mathrm{R}}$ a fotorrespiração.

A fotossíntese líquida das plantas responde de forma hiperbólica (Figura 3.6) à densidade de fluxo fotônico. O nível de radiação no qual a taxa fotossintética líquida $\left(\mathrm{F}_{\mathrm{N}}\right)$ se iguala a zero é denominado "ponto de compensação de luz ou irradiância de compensação". Na irradiância de compensação, o intercâmbio líquido de $\mathrm{CO}_{2}$ é igual a zero. Abaixo da irrandiância de compensação, ocorre perda líquida de $\mathrm{CO}_{2}$.

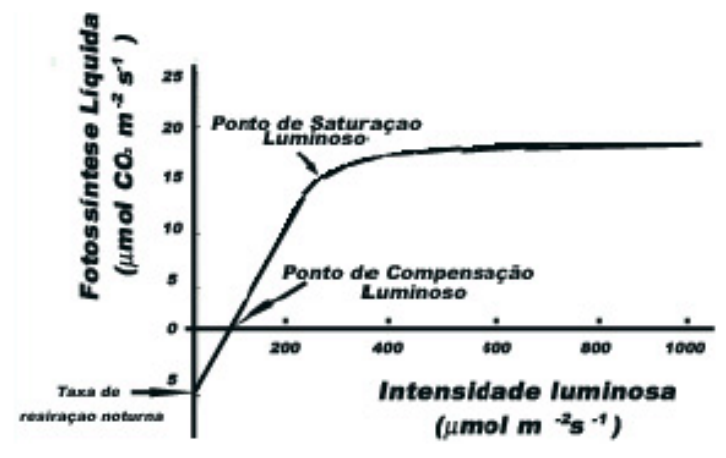

Figura 3.6 Resposta da fotossíntese a diferentes intensidades luminosas (LOUREIRO, et al., 2003).

De acordo com seu requerimento de luz, as plantas podem ser classificadas como plantas de sol e plantas de sombra. As plantas de sol são mais eficientes no uso da luz, ou seja, respondem melhor aos incrementos da radiação. As plantas de sombra saturaram-se com baixos níveis de radiação, mas são mais efetivas no uso da radiação porque têm fotossíntese líquida com pouca luz. Isso se deve principalmente ao menor nível de respiração nessas plantas. Nas plantas de sol, a irradiância de 
compensação está na faixa de 10 a $20 \mu \mathrm{mol} \cdot \mathrm{m}^{-2} \cdot \mathrm{s}^{-1}$. Nas plantas de sombra, a irradiância de compensação está na faixa de 1 a $5 \mu \mathrm{mol} \cdot \mathrm{m}^{-2} \cdot \mathrm{s}^{-1}$.

Com relação à disponibilidade de $\mathrm{CO}_{2}$, desde 1850 a 1950, a concentração de $\mathrm{CO}_{2}$ atmosférico aumentou de 280 para $315 \mathrm{ppm}$, representando um acréscimo médio de 0,35 ppm.ano-1 ${ }^{-1}$ A concentração de $\mathrm{CO}_{2}$ atual está em torno de $360 \mathrm{ppm}$, sendo que a quantidade de $\mathrm{CO}_{2}$ atmosférico continua aumentando a uma taxa de 2 ppm.ano ${ }^{-1}$; prevê-se que no próximo século a concentração de $\mathrm{CO}_{2}$ atmosférico duplicará. Esse inevitável incremento nos níveis de $\mathrm{CO}_{2}$ afetará diretamente as plantas nos sistemas naturais, agrícolas e florestais.

$\mathrm{Na}$ medida em que o $\mathrm{CO}_{2}$ do ambiente se incrementa, a taxa fotossintética das plantas tipo C3 também aumenta significativamente. No entanto o incremento da fotossíntese em plantas tipo $\mathrm{C} 4$ é menor.O ponto de compensação de $\mathrm{CO}_{2}$ é aquela concentração de $\mathrm{CO}_{2}$ na qual a fotossíntese líquida $\left(\mathrm{F}_{\mathrm{N}}\right)$ é zero. Só a partir desse ponto ocorre acumulação de reservas e, portanto, crescimento.

No que se refere ao fator temperatura, baixas temperaturas reduzem a velocidade das reações enzimáticas, reduzindo mais significativamente a fotossíntese do que a respiração. Temperaturas acima da temperatura ótima podem aumentar a fotorrespiração em plantas $\mathrm{C} 3$, visto que diminui a razão entre as concentrações de gás carbônico e oxigênio $\left(\left[\mathrm{CO}_{2}\right] /\left[\mathrm{O}_{2}\right]\right)$ dentro da célula, favorecendo a fotorrespiração.

Plantas expostas a maiores concentrações de $\mathrm{CO}_{2}$ apresentam aumento da fotossíntese líquida entre 25 e $35^{\circ} \mathrm{C}$, aumento não verificado em plantas expostas a concentrações normais de $\mathrm{CO}_{2}$. 


\subsection{Conceitos básicos sobre redes neurais artificiais (ANNs $\left.{ }^{*}\right)$}

Redes neurais artificiais são sistemas computacionais cujo enfoque central é adotado da analogia das redes neurais biológicas. A idéia de ANNs não é replicar a operação dos sistemas biológicos, mas sim fazer uso do conhecimento acerca do funcionamento das redes biológicas para resolver problemas complexos do mundo real (BASHEER e HAJMEER, 2000).

A atração pelas redes neurais deve-se principalmente: (1) à característica de não linearidade, propriedade inerente ao neurônio, que permite um melhor ajuste dos dados, sendo extremamente importante nos casos onde o sinal (ou entrada) analisado é gerado por um dispositivo não linear; (2) à tolerância a falhas, pois como a saída da rede recebe contribuições de todos os neurônios da rede, caso haja falha em um neurônio, ou em um conjunto de conexões, a saída apenas será degradada; (3) ao alto paralelismo, possibilitando um rápido processamento e tolerância a falhas; (4) à capacidade de aprendizado, pois as ANNs podem modificar sua estrutura interna em resposta às variações ambientais; e (5) à capacidade de generalização, que é a capacidade de gerar respostas adequadas, para entradas que não the foram apresentadas durante o treinamento (BASHEER e HAJMEER, 2000; HAYKIN, 1994; WASSERMAN, 1989).

\subsubsection{Neurônio biológico}

O sistema nervoso humano é uma arquitetura complexa, e está constituído por células chamadas de neurônios. O neurônio tem muitas características em comum com outras células do corpo mas somente ele tem a capacidade de receber, processar e transmitir sinais eletroquímicos através das conexões neurais, as quais compreendem o sistema de comunicação do cérebro (WASSERMAN, 1989).

\footnotetext{
* Nesta tese será utilizada a abreviatura em inglês ANNs (Artificial Neural Networks) para referirse a redes neurais artificiais para evitar uma eventual confusão com a sigla comumente adotada, mesmo em português, para designar o ácido ribonucléico, RNA.
} 
Um neurônio biológico típico, cujo esquema simplificado é mostrado na Figura 3.7, é formado basicamente por dendritos, corpo da célula ou soma, e o axônio. Os dendritos recebem os sinais de outros neurônios e os passam ao corpo da célula. No corpo da célula acontece a soma dos sinais que entram no neurônio; algumas entradas tendem a excitar a célula, outras tendem a inibir seu disparo. Quando a soma dos sinais atinge um limiar, a célula dispara, isto é, esta transmite um sinal pelo seu axônio para outras células. Em outras palavras, o axônio recebe o sinal do corpo da célula e o transmite, através da sinapse, para os dendritos dos neurônios vizinhos. O ponto de contato entre os terminais do axônio de um neurônio e os dendritos de outros neurônios é chamado de sinapse, através da qual a informação é propagada. Devido a um neurônio ter um grande número de dendritos/sinapses, ele pode receber e transmitir muitos sinais simultaneamente. Este mecanismo simplificado de transferência de sinal constitui o passo fundamental para o desenvolvimento da neurocomputação (BASHEER e HAJMEER, 2000; FAUSETT, 1994).

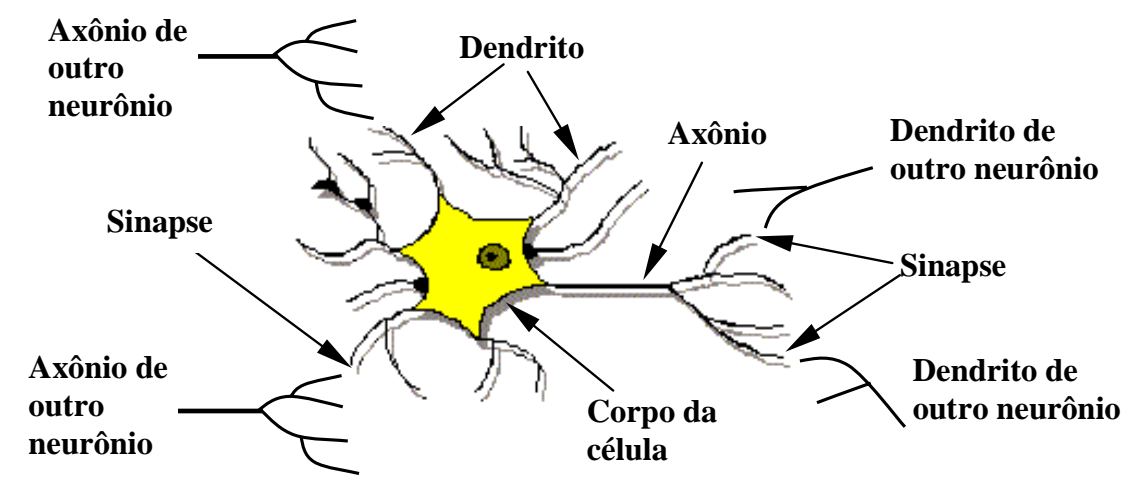

Figura 3.7 Esquemas simplificado de um neurônio biológico.

\subsubsection{Neurônio artificial}

O neurônio artificial foi desenhado imitando algumas características do neurônio biológico. Em essência, um conjunto de entradas é aplicado a um neurônio artificial, cada entrada representando a saída de outros neurônios. Cada entrada é 
multiplicada por um correspondente peso, e todas essas entradas multiplicadas pelos pesos são então somadas para determinar o nível de ativação do neurônio. Na Figura 3.8 é mostrado um modelo que cumpre esta idéia. Apesar da diversidade de modelos de redes, todos são baseados nesta configuração. Um conjunto de entradas $x_{1}, x_{2}, \ldots$, $x_{n}$ é aplicado ao neurônio artificial. Estas entradas, as quais são referidas coletivamente como o vetor $\mathrm{X}$, correspondem aos sinais recebidos pelos dendritos. Cada sinal é multiplicado por um peso associado $w_{1}, w_{2}, \ldots, w_{n}$, antes de ser aplicado ao bloco de soma (chamado $\Sigma$ ). Cada peso corresponde à "força ou potência (strength)" de uma conexão sináptica biológica; o conjunto de pesos é referido coletivamente como o vetor W. O bloco de soma, que corresponde aproximadamente ao corpo da célula biológica, realiza a soma algébrica de todas as entradas multiplicadas pelos seus pesos associados, produzindo uma saída, chamada aqui de NET.

$$
N E T=X . W=x_{1} w_{1}+x_{2} w_{2}+\ldots+x_{n} w_{n}
$$

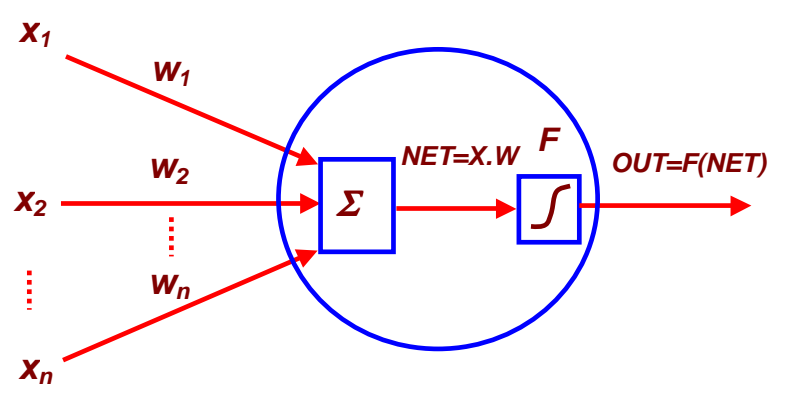

Figura 3.8 Esquema de um neurônio artificial com função de ativação.

O sinal NET é processado por uma função de ativação F para produzir o sinal de saída do neurônio, OUT. Este pode ser uma simples função linear, tal como:

$$
O U T=K(N E T)
$$

Onde K é uma constante, uma função limiar.

$$
\begin{array}{ll}
\text { OUT }=1 & \text { se NET }>\mathrm{T} \\
\text { OUT }=0 & \text { caso contrário }
\end{array}
$$


Onde $\mathrm{T}$ é um valor limiar constante, ou uma função que simula mais exatamente as características de transferência não-linear de um neurônio biológico.

Este modelo simples de neurônio artificial ignora muitas das características

de sua contraparte biológica. Apesar dessas limitações, redes formadas por estes neurônios mostram atributos que lembram fortemente o sistema biológico (WASSERMAN, 1989).

\subsubsection{Redes neurais artificiais}

Uma rede neural artificial é um sistema de processamento de informação que tem certas características de desempenho em comum com as redes neurais biológicas. Redes neurais artificiais têm sido desenvolvidas como generalizações de modelos matemáticos do conhecimento humano ou biologia neural, baseados nas seguintes suposições:

1. O processamento da informação acontece em muitos elementos simples chamados neurônios.

2. Os sinais são passados entre os neurônios por conexões de ligação.

3. Cada conexão de ligação tem um peso associado, o qual em uma rede neural típica, multiplica o sinal transmitido.

4. Cada neurônio aplica uma função de ativação (usualmente não linear) para sua rede de entrada (soma de pesos dos sinais de entrada) para determinar seu sinal de saída (FAUSETT, 1994).

Portanto, uma rede neural consiste de um grande número de elementos de processamento simples chamados neurônios, unidades, células ou nodos. Cada neurônio é conectado a outros neurônios por meio de ligações de comunicação direta, cada um com um peso associado. Os pesos representam informações que são usadas pela rede para resolver um problema. Cada neurônio tem um estado interno, chamado ativação ou nível de atividade, o qual é função das entradas que recebe. Tipicamente, cada neurônio envia sua ativação como um sinal para outros neurônios. 
Em geral, uma rede neural é caracterizada por seu padrão de conexões entre os neurônios (chamado de arquitetura), seu método para determinar os pesos sobre as conexões (chamado de treinamento, aprendizagem, ou algoritmo), e sua função de ativação.

\subsubsection{Arquiteturas típicas de ANNs}

O arranjo dos neurônios em camadas e os padrões de conexão dentro e entre as camadas é chamada de arquitetura de rede. Tipicamente, os neurônios de uma mesma camada têm igual comportamento. Os fatores fundamentais que determinam o comportamento de um neurônio são sua função de ativação e o padrão de conexão dos pesos, sobre os quais os sinais são enviados e recebidos (FAUSETT, 1994).

Geralmente as redes neurais são classificadas como single-layer (única camada) ou multilayer (multicamada). Na determinação do número de camadas, algumas vezes, as unidades de entrada não são contadas como uma camada, porque elas não desempenham nenhuma operação de cômputo. Equivalentemente, o número de camadas em uma rede, pode ser definida pelo número de camadas das conexões dos pesos entre os arranjos de neurônios.

Redes single-layer e multilayer são exemplos de redes feedforward (alimentação direta), as quais são ilustradas na Figura 3.9. Neste tipo de arquitetura os sinais fluem desde as unidades de entrada até as unidades de saída, seguindo a direção para adiante.

Uma rede single-layer, ilustrada na Figura 3.9a, tem unicamente uma camada de conexão de pesos. Geralmente, as unidades podem ser distinguidas como unidades de entrada, as quais recebem sinais do mundo externo, e unidades de saída, desde as quais a resposta da rede pode ser lida. 
Uma rede multilayer, ilustrada na Figura 3.9b, é uma rede com uma ou mais camadas de unidades (chamadas unidades escondidas) entre as unidades de entrada e as unidades de saída.

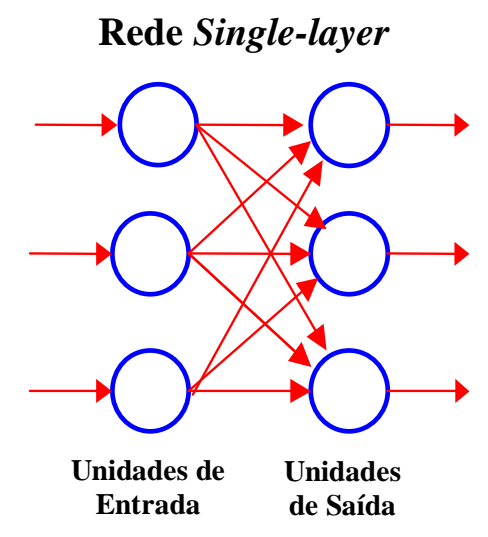

(a)

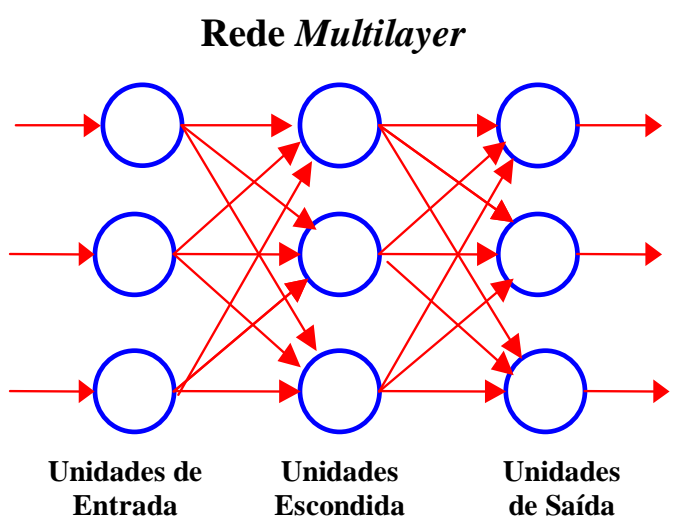

(b)

Figura 3.9 Ilustração de redes feedforward.

\subsubsection{Tipos de aprendizado (treinamento)}

Além da arquitetura da rede, o método para definir os valores dos pesos (treinamento) é uma característica importante que distingue as diferentes redes neurais. Os algoritmos de treinamento são categorizados como supervisionados e não supervisionados (FAUSETT, 1994; WASSERMAN, 1989).

Treinamentos supervisionados requerem pares de vetores de treinamento, isto é, vetores de entrada com seus correspondentes vetores de referência que representam a saída desejada. Portanto a rede é treinada com os pares de vetores de treinamento da seguinte forma: um vetor de entrada é aplicado, a saída da rede é calculada e comparada com o vetor de referência, e a diferença (erro) é realimentada através da rede, e os pesos são variados de acordo com um algoritmo que tende a minimizar o erro. 
Treinamentos não supervisionados não requerem vetores de referência para a saída; o conjunto de treinamento consiste unicamente de vetores de entrada. O algoritmo de treinamento modifica os pesos da rede para produzir vetores de saída que sejam consistentes. Portanto a rede deve descobrir por si mesma padrões, características, regularidades, correlações, ou categorias no dado de entrada e codificá-las na saída.

\subsubsection{Função de ativação (função de transferência)}

Como foi visto no item 3.2.2, neurônio artificial, o fator final que governa a saída do neurônio é a função de ativação, chamada também de função de transferência. Esta função pode ser raiz quadrada, $\log , \mathrm{e}^{\mathrm{x}}$, entre outras, e é escolhida dependendo da aplicação.

Funções sigmoidal são funções de ativação úteis; a função logistic e a função tangente hiperbólica são as mais comuns. Elas são especialmente vantajosas para serem usadas em redes neurais treinadas com o algoritmo backpropagation (retropropagação), devido a existir uma relação simples entre o valor da função em um ponto e o valor da derivada nesse ponto, o qual reduz a carga computacional durante o treinamento.

Na Figura 3.10a e na Figura 3.10b são mostrados os gráfico e as expressões matemáticas das funções logistic e tangente hiperbólica, respectivamente. Elas são incrementadas monotonicamente, com valores limites de $0(\mathrm{em} x=-\infty)$ e 1 $($ em $\mathrm{x}=+\infty)$ para a função logistic, e com valores limites de $-1($ em $\mathrm{x}=-\infty)$ e 1 $($ em $\mathrm{x}=+\infty)$ para a função tangente hiperbólica.

Todas as funções sigmoidal têm valores limitantes superiores e inferiores, os quais são chamados de limiares. Com estas funções, os efeitos inibitórios e estimuladores dos fatores de peso são diretos $\left(\mathrm{w}_{\mathrm{ij}}<0\right.$ é inibitório, e $\mathrm{w}_{\mathrm{ij}}>0$ é 
estimulador). Pode-se ver que as funções sigmoidal são contínuas e monotônicas, e permanecem finitas quando $\mathrm{x}$ tende $\mathrm{a} \pm \infty$.

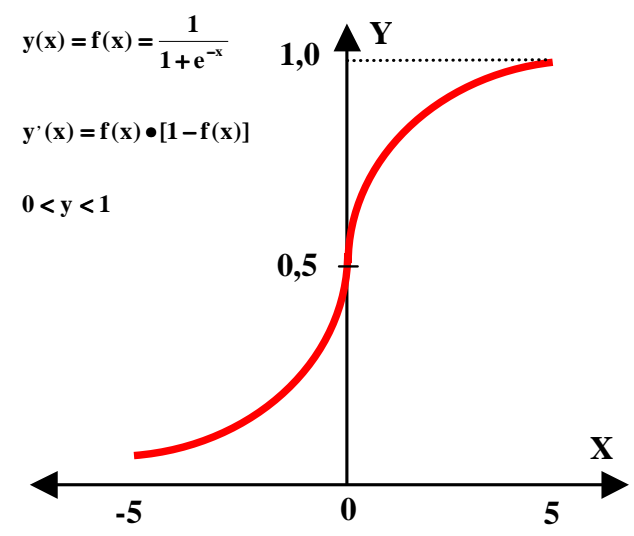

(a)

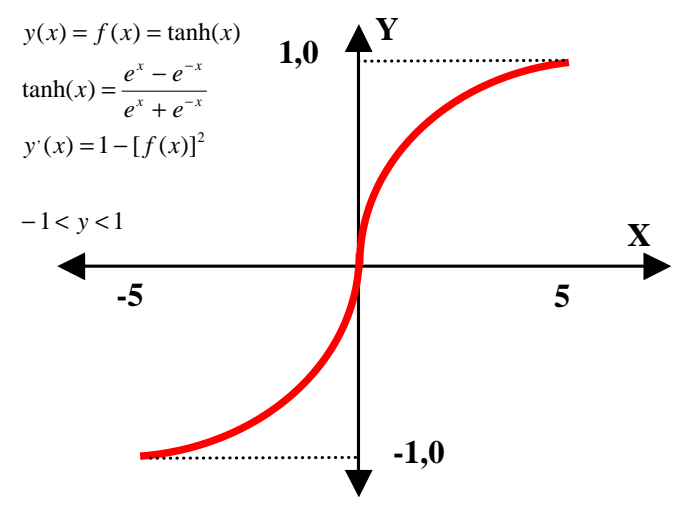

(b)

Figura 3.10 Funções de ativação (a) Função logistic (b) Função tangente hiperbólica.

\subsubsection{Redes MLP (Multilayer Perceptron)}

As redes MLP com algoritmo de treinamento backpropagation (retropropagação) é chamado também como rede multilayer feedforward (MLFF) ou rede backpropagation. Estas redes provavelmente são as mais conhecidas, pesquisadas e amplamente utilizadas. Redes MLP são versáteis e podem ser utilizadas para modelagem de dados (aproximação de funções), classificação, previsão, controle, compressão de dados e imagem, e reconhecimento de padrões. Consiste de uma camada de entrada com unidades representando as variáveis de entrada de um dado problema, uma camada de saída com unidades representando as variáveis dependentes (variáveis que estão sendo modeladas), e uma ou mais camadas escondidas contendo unidades para ajudar a capturar a não-linearidade no processo. A rede MLP utiliza o aprendizado supervisionado com algoritmo de treinamento backpropagation (BASHEER e HAJMEER, 2000; FAUSETT, 1994; HAYKIN, 1994; PATTERSON, 1996; WASSERMAN, 1989). 
Bacpropagation, também conhecido como regra delta generalizada, é o procedimento mais difundido para treinamento de ANNs, e é baseado na procura de uma superfície de erro (erro em função dos pesos das ANNs) utilizando o método do gradiente descendente (gradient descent). Cada iteração no backpropagation é formada por três estágios: a alimentação direta (feedforward) do padrão de treinamento de entrada, o cálculo e retropropagação do erro associado, e o ajuste dos pesos. Depois do treinamento, a aplicação da rede envolve somente os cálculos da fase de alimentação direta. Na Figura 3.11 é mostrado o esquema de uma rede MLP com algoritmo de treinamento backpropagation.

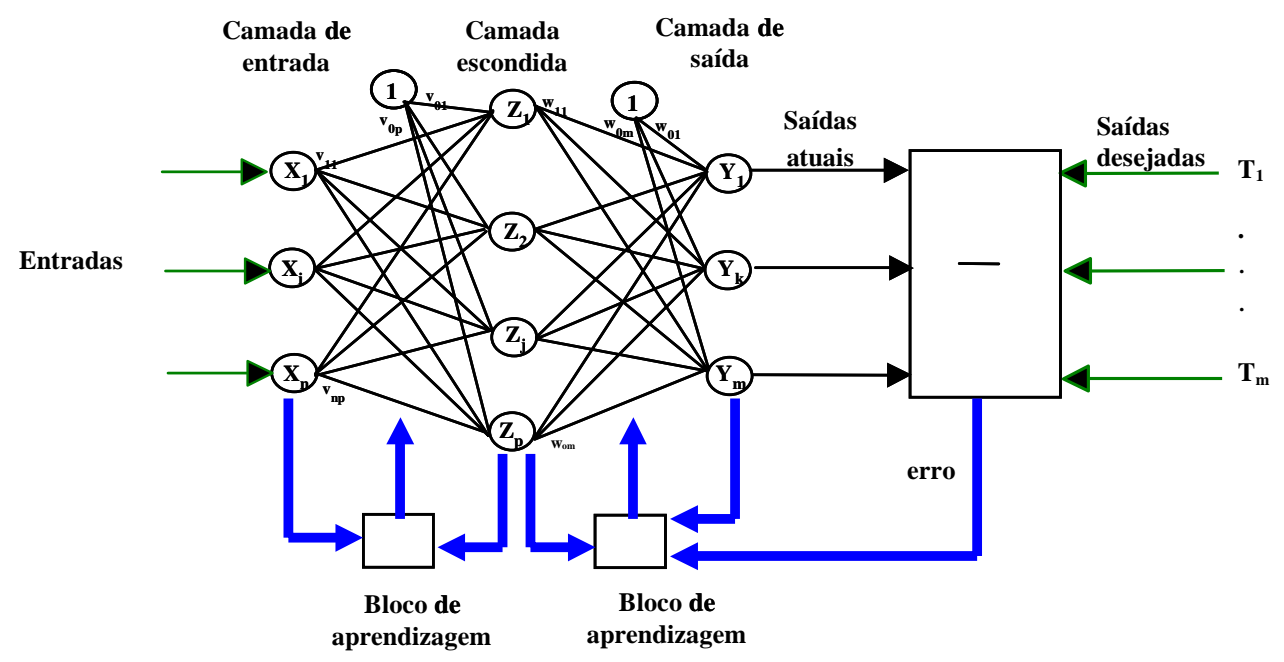

Figura 3.11 Rede neural MLP com algoritmo de treinamento backpropagation.

Como foi mencionado, o treinamento de uma rede com algoritmo backpropagation envolve três estágios: a alimentação direta (feedforward) do padrão de treinamento de entrada, o cálculo e retropropagação do erro associado, e o ajuste dos pesos. Durante a alimentação direta, cada unidade de entrada $\left(\mathrm{X}_{\mathrm{i}}\right)$ recebe um sinal de entrada e o propaga para cada unidade escondida $Z_{1}, \ldots, Z_{p}$. Cada unidade escondida calcula sua ativação e envia seu sinal $\left(\mathrm{z}_{\mathrm{j}}\right)$ para cada unidade de saída. Cada unidade de saída $\left(\mathrm{Y}_{\mathrm{k}}\right)$ calcula sua ativação $\left(\mathrm{y}_{\mathrm{k}}\right)$ para formar a resposta de rede para um padrão de entrada dado. 
Durante o treinamento, cada unidade de saída compara sua ativação calculada $\mathrm{y}_{\mathrm{k}}$ com seu valor desejado $\mathrm{t}_{\mathrm{k}}$ para determinar o erro associado para esse padrão com essa unidade. Baseado neste erro, o fator $\delta_{\mathrm{k}}(\mathrm{k}=1, \ldots, \mathrm{m})$ é calculado. $\delta_{\mathrm{k}}$ é usado para que o erro distribuído nas unidades de saída $\left(\mathrm{Y}_{\mathrm{k}}\right)$ retorne para todas as unidades das camadas prévias (as unidades escondidas que estão conectadas a $\mathrm{Y}_{\mathrm{k}}$ ). Este fator também é usado para atualizar os pesos entre a camada de saída e a camada escondida. De forma similar, o fator $\delta_{\mathrm{j}}(\mathrm{j}=1, \ldots, \mathrm{p})$ é calculado para cada unidade escondida $Z_{\mathrm{j}}$. Neste caso não é necessário propagar o erro de retorno para as unidades de entrada, mas $\delta_{\mathrm{j}}$ é utilizado para atualizar os pesos entre a camada escondida e a camada de entrada.

Uma vez que todos os fatores $\delta$ são determinados, os pesos de todas as camadas são ajustados simultaneamente. $\mathrm{O}$ ajuste para o peso $\mathrm{w}_{\mathrm{jk}}$ (desde a unidade escondida $Z_{j}$ para a unidade de saída $Y_{k}$ ) é baseado no fator $\delta_{k}$ e na ativação $z_{j}$ da unidade escondida $Z_{j}$. $O$ ajuste para o peso $v_{i j}$ (desde a unidade de entrada $X_{i}$ para a unidade escondida $Z_{j}$ ) é baseado no fator $\delta_{j}$ e na ativação $x_{i}$ da unidade de entrada.

As unidades nomeadas com 1 (Figura 3.11) são os neurônios de polarização.

A função de ativação, para uma rede MLP com algoritmo de treinamento backpropagation, deve ter várias características importantes tais como ser contínua, diferenciável e monotonicamente não decrescente. Além disso, para eficiência computacional, é desejável que sua derivada seja fácil de calcular. As funções de ativação mais típicas são as funções sigmóides logistic e a tangente hiperbólica.

\section{O algoritmo backpropagation padrão é como segue:}

Passo 0. Inicializar os pesos.

(Configurar para valores aleatórios pequenos)

Passo 1. Enquanto (While) a condição de parada é falsa, fazer Passos 2 - 9 .

Passo 2. Para cada par de treinamento, fazer Passos $3-8$. 


\section{Feedforward:}

Passo 3. Cada unidade de entrada $\left(X_{i}, i=1, \ldots, n\right)$ recebe sinais de entrada $x_{i}$ e propaga este sinal para todas as unidades na camada superior (unidades escondidas).

Passo 4. Cada unidade escondida $\left(Z_{j}, j=1, \ldots, p\right)$ soma o produto de seus sinais de entrada $\left(\mathrm{x}_{\mathrm{i}}\right)$ pelos pesos $\left(\mathrm{v}_{\mathrm{ij}}\right)$ existentes entre a camada de entrada e a camada escondida.

$$
z_{-} i n_{j}=v_{0 j}+\sum_{i=1}^{n} x_{i} v_{i j}
$$

onde $\mathrm{v}_{0 \mathrm{j}}$ é a polarização da unidade escondida $Z_{\mathrm{j}}$.

Aplica sua função de ativação para calcular seu sinal de saída,

$$
z_{j}=f\left(z_{-} i n_{j}\right)
$$

e envia este sinal para todas as unidades na camada de cima (unidades de saída).

Passo 5. Cada unidade de saída $\left(\mathrm{Y}_{\mathrm{k}}, \mathrm{k}=1, \ldots, \mathrm{m}\right)$ soma o produto de seus sinais de entrada $\left(\mathrm{z}_{\mathrm{j}}\right)$ pelos pesos $\left(\mathrm{w}_{\mathrm{jk}}\right)$ existentes entre a camada escondida e a saída,

$$
y_{-} i n_{k}=w_{0 k}+\sum_{j=1}^{p} z_{j} w_{j k},
$$

onde $\mathrm{w}_{0 \mathrm{k}}$ é a polarização da unidade de saída $\mathrm{Y}_{\mathrm{k}}$.

Aplica sua função de ativação para calcular seu sinal de saída,

$$
y_{k}=f\left(y_{-} i n_{k}\right) \text {. }
$$

\section{Erro de retropropagação (backpropagation):}

Passo 6. Cada unidade de saída $\left(\mathrm{Y}_{\mathrm{k}}, \mathrm{k}=1, \ldots, \mathrm{m}\right)$ recebe um padrão desejado correspondente ao padrão de treinamento de entrada, calcula seu termo de informação de erro,

$$
\delta_{k}=\left(t_{k}-y_{k}\right) f^{\prime}\left(y_{-} i n_{k}\right),
$$

calcula seu termo de correção de peso (usado para 
atualizar depois $\left.\mathrm{w}_{\mathrm{jk}}\right)$,

$$
\Delta w_{j k}=\alpha \delta_{k} z_{j}
$$

calcula seu termo de correção de polarização (usado para atualizar depois $\left.\mathrm{w}_{0 \mathrm{k}}\right)$,

$$
\Delta w_{0 k}=\alpha \delta_{k},
$$

e envia $\delta_{\mathrm{k}}$ para as unidades na camada de baixo. Onde $\alpha$ é a relação de aprendizado (coeficiente de aprendizado).

Passo 7. Cada unidade escondida $\left(Z_{j}, j=1, \ldots, p\right)$ soma suas entradas delta (desde as unidades na camada de baixo),

$$
\delta_{-} i n_{j}=\sum_{k=1}^{m} \delta_{k} w_{j k},
$$

multiplica pela derivada de sua função de ativação para calcular seu termo de erro de informação,

$$
\delta_{j}=\delta_{-} i n_{j} f^{\prime}\left(z_{-} i n_{j}\right)
$$

calcula seu termo de correção de pesos (usado para atualizar depois $\mathrm{v}_{\mathrm{ij}}$ ),

$$
\Delta v_{i j}=\alpha \delta_{j} x_{i},
$$

e calcula seu termo de correção de polarização (usado para atualizar depois $\mathrm{v}_{0 \mathrm{j}}$ ),

$$
\Delta v_{0 j}=\alpha \delta_{j} .
$$

\section{Atualizar pesos e polarizações:}

Passo 8. Cada unidade de saída $\left(\mathrm{Y}_{\mathrm{k}}, \mathrm{k}=1, \ldots, \mathrm{m}\right)$ atualiza seus

pesos e polarizações $(j=0, \ldots, p)$ :

$$
w_{j k}(\text { novo })=w_{j k}(\text { velho })+\Delta w_{j k} .
$$

Cada unidade escondida $\left(Z_{j}, j=1, \ldots, p\right)$ atualiza seus

pesos e polarizações $(\mathrm{i}=0, \ldots, \mathrm{n})$ :

$$
v_{i j}(\text { novo })=v_{i j}(\text { velho })+\Delta v_{i j} .
$$

Passo 9. Teste da condição de parada. 
Pode se notar que na implementação deste algoritmo, matrizes separadas devem ser usadas para os deltas das unidades de saída (Passo 6, $\boldsymbol{\delta}_{\mathbf{k}}$ ), e os deltas das unidades escondidas (Passo 7, $\boldsymbol{\delta}_{\mathbf{j}}$ ).

Para melhorar a eficiência do algoritmo backpropagation foram realizadas várias modificações (FAUSETT, 1994; PATTERSON, 1996; WASSERMAN, 1989). Uma dessas modificações é o método do "momentum", uma técnica para reduzir o tempo do treinamento. O método envolve a adição de um termo para ajustar o peso atual, o qual é proporcional à quantidade do peso prévio. As equações de atualização de pesos para o algoritmo backpropagation com momentum são:

$$
\begin{gathered}
\Delta w_{j k}(t+1)=\alpha \delta_{k} z_{j}+\mu \Delta w_{j k}(t) \\
w_{j k}(t+1)=w_{j k}(t)+\Delta w_{j k}(t+1)
\end{gathered}
$$

Para os pesos $\mathrm{v}_{\mathrm{ij}}$ utilizam-se as mesmas equações, substituindo $\mathrm{w}_{\mathrm{jk}}$ por $\mathrm{v}_{\mathrm{ij}}$.

Onde $\mu$ é o coeficiente do momentum, que está restrito à faixa de $0<\mu<1$, e $\alpha$ é o coeficiente de aprendizado. O termo momentum representa um fração do valor da variação dos pesos, das iterações de treinamento prévio.

Usando o método do momentum, a rede tende a alcançar a parte baixa da superfície do erro. Ainda que ocasionalmente se encontre um mínimo local no trajeto descendente, introduzindo um momentum este poderá ser superado e eventualmente atingir o mínimo global da superfície do erro.

O método do momentum parece funcionar bem em alguns problemas, mas ele tem efeitos pequenos ou negativos em outros. Outro método similar baseado na suavização exponencial (exponential smoothing) pode ser melhor em algumas aplicações (WASSERMAN, 1989). As equações de atualização de pesos com o método de suavização exponencial são:

$$
\Delta w_{j k}(t+1)=\left(\mu \Delta w_{j k}(t)+(1-\mu) \delta_{k} z_{j}\right) \alpha
$$




$$
w_{j k}(t+1)=w_{j k}(t)+\Delta w_{j k}(t+1)
$$

Sendo $\mu$ o coeficiente de suavização exponencial na faixa de $\mathbf{0}<\mu<\mathbf{1}$, e $\alpha$ é o coeficiente de aprendizado.

Convém ressaltar que existem diferentes modelos de redes neurais, e aqui foi apresentado unicamente o modelo MLP, devido a ser ele o modelo utilizado nesta pesquisa.

\subsubsection{Aplicação das redes neurais artificiais}

O estudo das redes neurais artificiais é extremamente interdisciplinar, tanto em seu desenvolvimento como em sua aplicação. Algumas áreas onde as redes neurais estão sendo aplicadas são: classificação de padrões, agrupamento (clustering), aproximação de funções (modelagem ou interpolação), previsão (forecasting), otimização, associação, controle, entre outros (BASHEER e HAJMEER, 2000; FAUSETT, 1994; PATTERSON, 1996).

A aproximação de uma função envolve treinamento de uma ANN com dados de entrada-saída, para aproximar as regras subjacentes que relacionam as entradas com as saídas. Redes neurais multilayer são consideradas aproximadores universais que podem aproximar qualquer função arbitrária para qualquer grau de precisão. A aproximação de uma função é aplicada (i) para problemas onde nenhum modelo teórico é disponível, isto é, dados obtidos de experimentos ou observações são utilizados, ou (ii) para substituir modelos teóricos que são difíceis de calcular analiticamente utilizando dados de tais modelos (BASHEER e HAJMEER, 2000). 


\section{MÉTODO PARA FITOMONITORAÇÃO E MODELAGEM DE FOTOSSÍNTESE BASEADO EM ANNs}

Este capítulo tratará sobre o método de trabalho proposto e realizado para atingir os objetivos desta pesquisa. Serão apresentados os métodos de fitomonitoração e modelagem de fotossíntese com redes neurais artificiais.

O método de fitomonitoração, ou coleta de dados fisiológicos em plântulas de jatobá e coleta de dados ambientais, foi a primeira etapa executada nesta pesquisa. Esta etapa compreendeu seis fases: definição de variáveis fisiológicas e ambientais, definição do local de experimentação, definição do sistema de fitomonitoração, definição do procedimento para a coleta de dados, coleta de dados, e processamento dos dados coletados. No item 4.1 serão explicados esses aspectos.

A segunda etapa executada foi o método de modelagem de fotossíntese, ou treinamento de redes neurais artificiais com os dados coletados. Esta etapa compreendeu as seguintes fases: preparo dos conjuntos de dados para o treinamento e o teste, definição da topologia da rede e dos parâmetros de treinamento, treinamento das redes neurais artificiais, e teste das redes neurais artificiais. Esses aspectos serão explicados no item 4.2. 


\subsection{Fitomonitoração}

Neste item tratar-se-á sobre o método de fitomonitoração realizado nesta pesquisa. Isto é, que variáveis fisiológicas e ambientais foram medidas, onde foram realizadas as medidas, quais foram os instrumentos utilizados, como foi o procedimento para coletar os dados, e como foram processados os dados coletados. A seguir serão tratados os seguintes pontos:

a) Variáveis fisiológicas e ambientais medidas

b) Local da experimentação

c) Sistema de fitomonitoração

d) Procedimento para a coleta de dados

e) Processamento dos dados coletados

\subsubsection{Variáveis fisiológicas e ambientais medidas}

Para desenvolver modelos de troca de $\mathrm{CO}_{2}$ são necessárias variáveis ambientais e variáveis fitofisiológicas. Na literatura encontra-se que as variáveis ambientais mais relevantes utilizadas nessa modelagem são: radiação fotossintética ativa, temperatura do ar, umidade relativa do ar, velocidade do vento, precipitação e concentração de $\mathrm{CO}_{2}$ atmosférico (BOEGH, et al., 1999; INFANTE, et al., 1999; KELLOMAKI e WANG, 2000;). Já as variáveis fitofisiológicas usualmente utilizadas são: fotossíntese, transpiração, condutância estomática, área foliar e temperatura da folha. Neste trabalho de pesquisa, modelagem de fotossíntese com redes neurais artificiais, foram realizadas medidas dessas variáveis, exceto velocidade do vento e precipitação, porque as medidas foram realizadas em uma casa de vegetação. Outra variável fisiológica medida foi a fluorescência, por estar diretamente relacionada com a fotossíntese.

Para realizar as medidas das variáveis fisiológicas foram utilizadas plântulas de Himenaea courbaril, popularmente conhecida como jatobá. O jatobá é uma 
leguminosa arbórea pouco exigente em fertilidade e umidade do solo, geralmente ocorrendo em terrenos bem drenados. No Brasil esta espécie é encontrada em florestas semidecíduas desde o Piauí até o norte do Paraná, tanto em solos de alta como de média fertilidade. A árvore atinge uma altura de 15-20 m, e o tronco pode medir até $1 \mathrm{~m}$ de diâmetro. As folhas são compostas de dois folíolos, de 6-14 cm de comprimento (LORENZI, 1992).

O jatobá fornece uma madeira dura e resistente à putrefação, que pode ser utilizada na construção civil. A árvore, de fácil multiplicação, não pode faltar na composição de reflorestamentos heterogêneos e na arborização de parques e grandes jardins. Os frutos contêm uma farinha comestível e muito nutritiva, consumida tanto pelo homem como pelos animais silvestres (LORENZI, 1992). Na Figura 4.1 mostram-se dois aspectos dessa espécie.

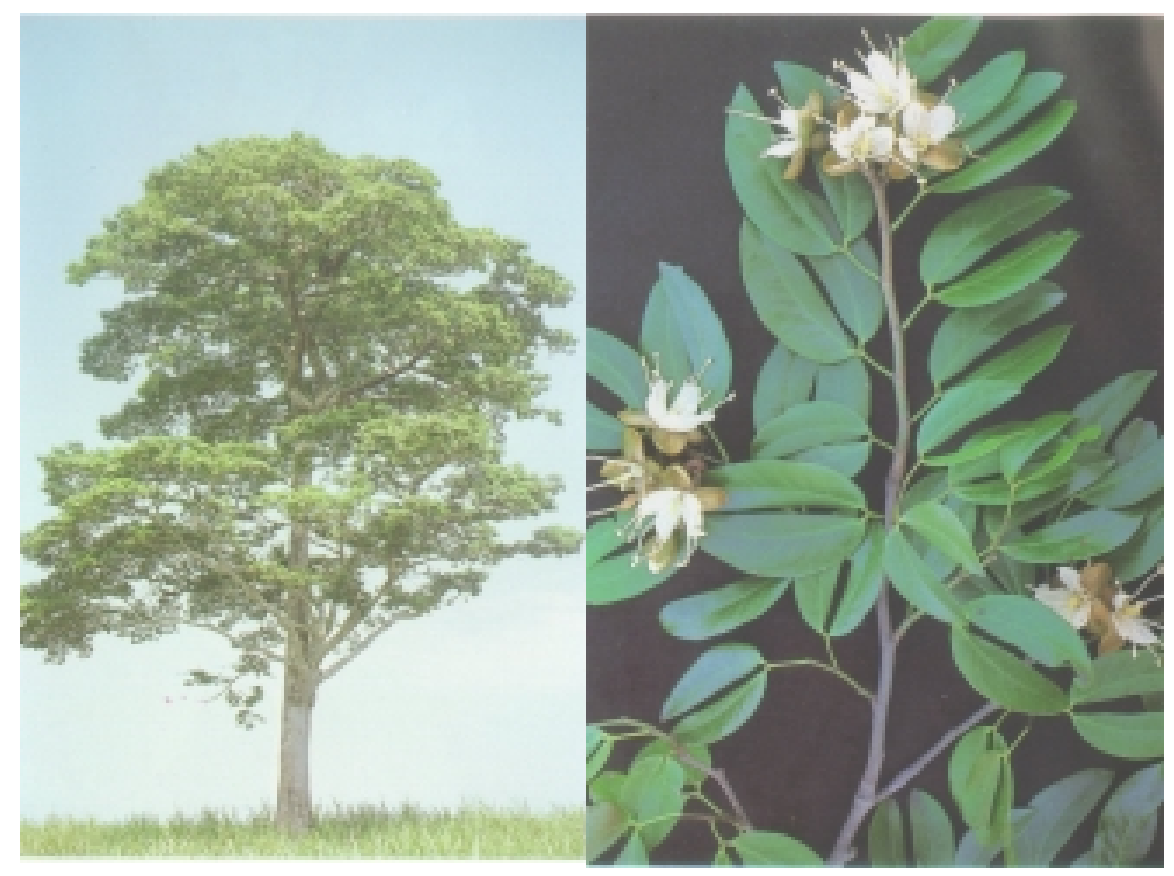

Figura 4.1 Jatobá, Hymenaea courbaril, (LORENZI, 1992). 


\subsubsection{Local da experimentação}

A parte experimental, coleta de dados, foi realizada no Instituto de Botânica, na Seção de Fisiologia e Bioquímica de Plantas, situado no Parque Estadual das Fontes do Ipiranga, bairro da Água Funda, na capital do Estado de São Paulo.

As medidas foram realizadas em oito plântulas de jatobá, as quais foram semeadas em outubro de 2000. Estas plântulas, denominadas plântula 1, plântula 2, até plântula 8 , tinham $7,9,9,7,8,9,8$ e 10 folhas, respectivamente, quando começou o experimento, em abril de 2001. Na Figura 4.2 são mostrados as plântulas e o sistema de medida portátil.

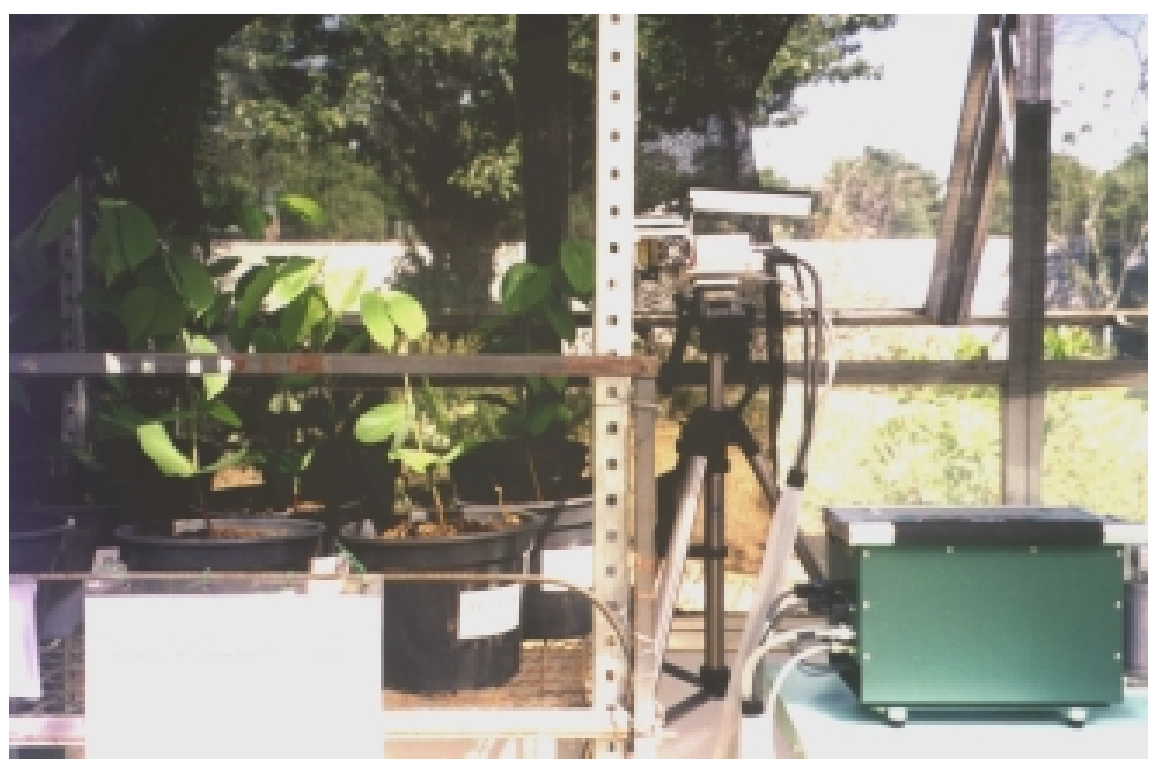

Figura 4.2 Plântulas de jatobá e sistema de medida portátil.

O jatobá, enquanto plântula, recebe baixa radiação luminosa em seu habitat natural. Para manter essa condição as plântulas foram colocadas em casa de vegetação, num estande coberto com tela sombrite (56 \% de redução da radiação). Na Figura 4.3 e na Figura 4.4 são mostrados a casa de vegetação e o estande respectivamente. Optou-se por realizar o experimento em casa de vegetação para possibilitar a coleta de dados mesmo em dias com chuva sem danificar os 
equipamentos utilizados, ao mesmo tempo em que se mantêm as plântulas sujeitas às variações ambientais, uma vez que o ambiente não é controlado.

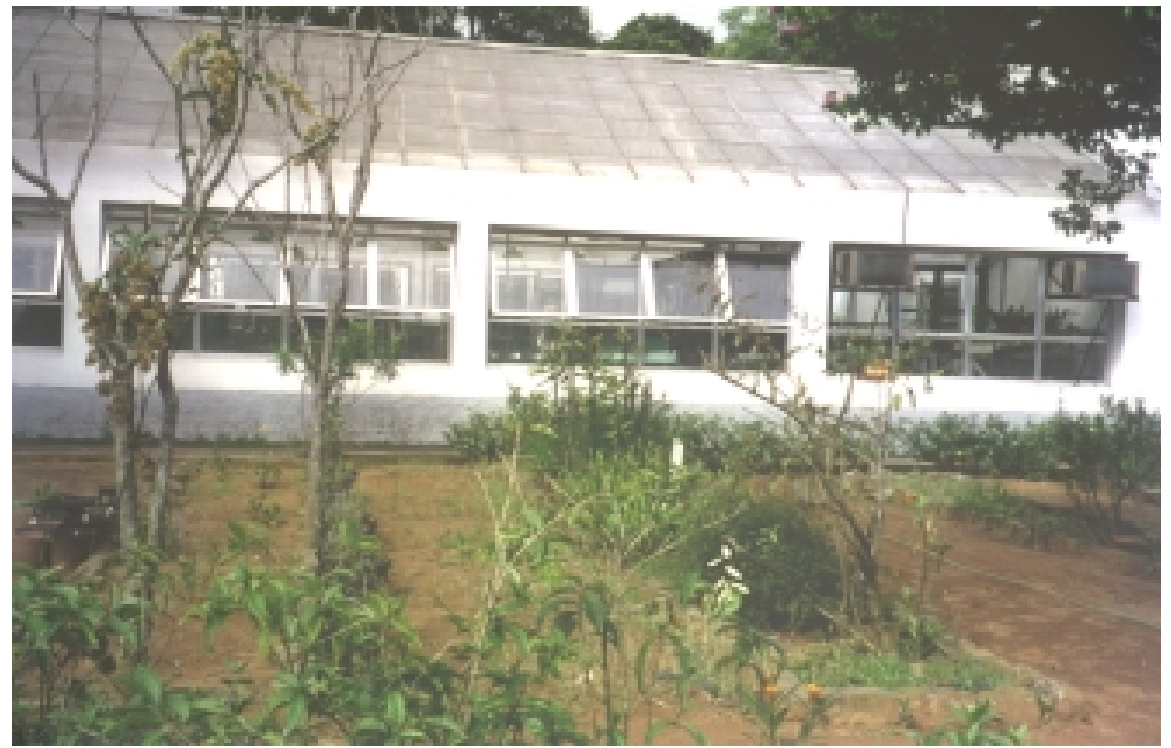

Figura 4.3 Casa de vegetação onde foram colocadas as plântulas de jatobá.

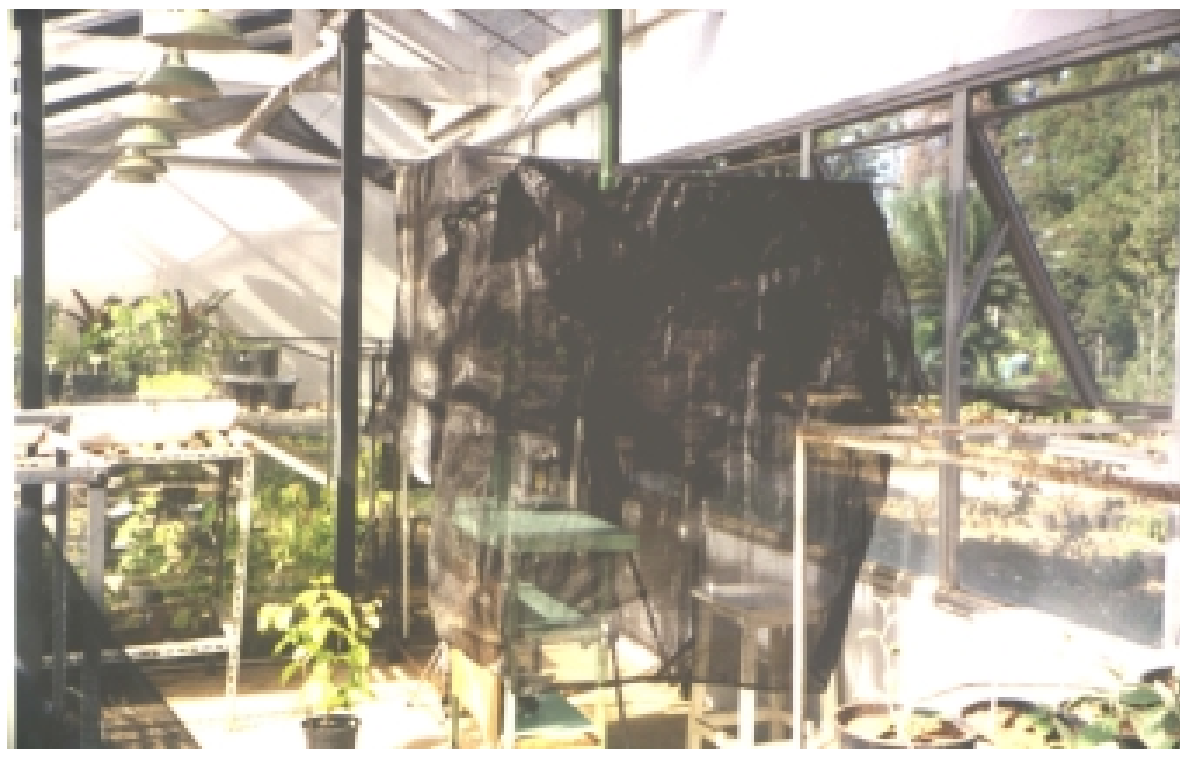

Figura 4.4 Estande, onde colocaram-se as plântulas, coberto com tela sombrite para reduzir a radiação. 


\subsubsection{Sistema de fitomonitoração}

O sistema de monitoração para a coleta de dados, variáveis ambientais e fisiológicas, é formado por: um sistema portátil de medida de fotossíntese, modelo LI-6400 (LI-COR, 1999), um medidor de área foliar portátil, modelo LI-3000A (LICOR, 1998), um fluorômetro, modelo OS5-FL (OPTI-SCIENCES, 1998) e um computador portátil (notebook). O sistema de medida de fotossíntese inclui: um analisador de gás, IRGA (Infrared Gas Analyzer), uma câmara de folha, sensores PAR (Photosynthetically Activity Radiation), e sensores de temperatura. Na Figura 4.5 é mostrado o diagrama em blocos do sistema de monitoração.

Na Tabela 4.1 indica-se o equipamento, o fabricante, o modelo, e a variável ou variáveis que foram medidas com o instrumento, assim como também as unidades das variáveis. Esses equipamentos pertencem ao Instituto de Botânica, Seção de Fisiologia e Bioquímica de Plantas, e foram financiados pela FAPESP (Projeto Temático BIOTA N 98/05124-8). Na Figura 4.6 são mostrados esses instrumentos.

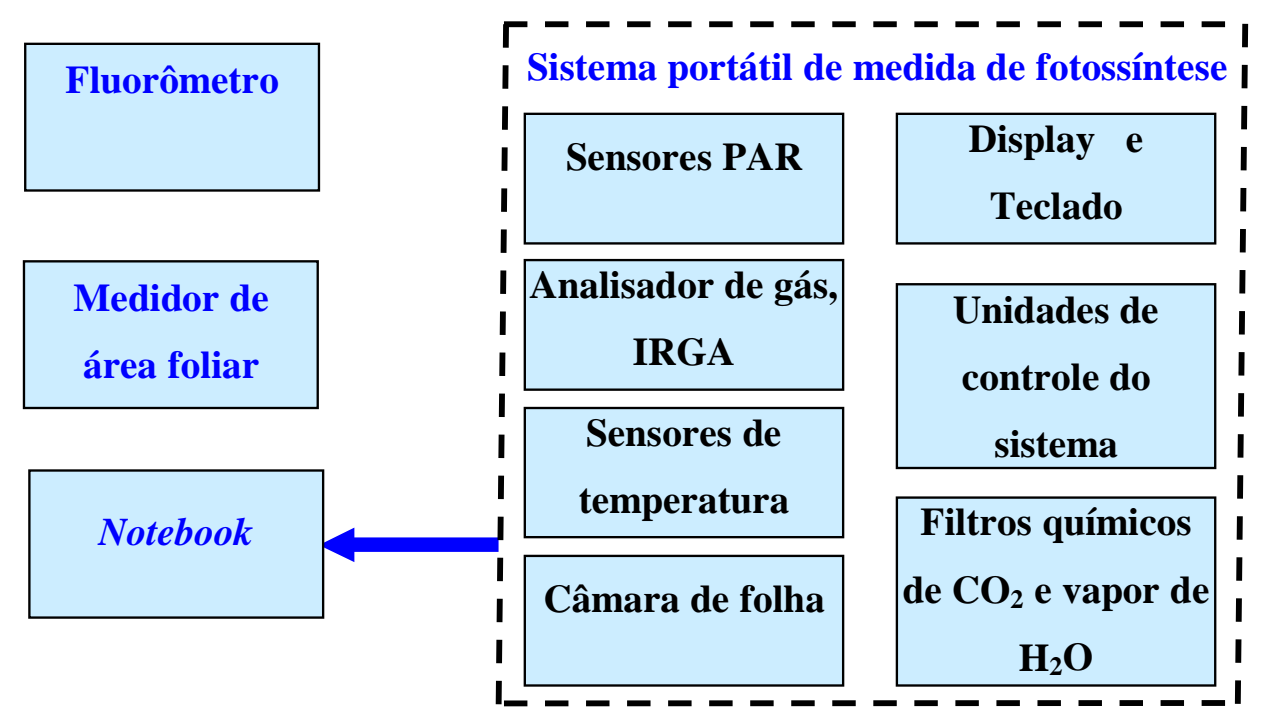

Figura 4.5 Diagrama em blocos do sistema de fitomonitoração. 
Tabela 4.1 - Equipamentos utilizados para o sistema de monitoração.

\begin{tabular}{|c|c|c|}
\hline Equipamento & Fabricante e modelo & Variável/função \\
\hline $\begin{array}{l}\text { Sistema de } \\
\text { medida de } \\
\text { fotossíntese } \\
\text { portátil }\end{array}$ & LI-COR, LI-6400 & 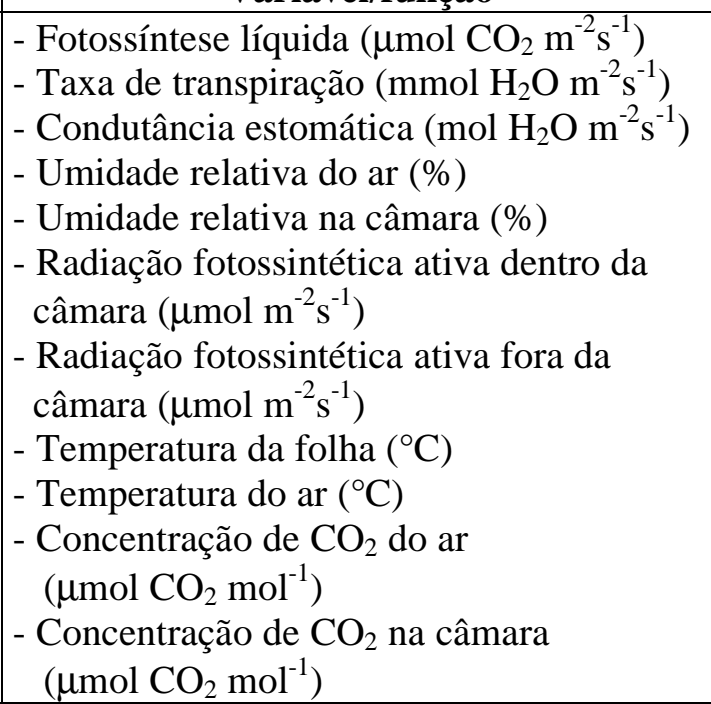 \\
\hline Fluorômetro & $\begin{array}{l}\text { OPTI-SCIENCES, } \\
\text { OS5-FL }\end{array}$ & $\begin{array}{l}\text { Fluorescência, Fv/Fm } \quad \text { (Eficiência } \\
\text { fotoquímica do PSII) }\end{array}$ \\
\hline $\begin{array}{l}\text { Medidor de } \\
\text { área foliar }\end{array}$ & LI-COR, LI-3000A & Área foliar $\left(\mathrm{cm}^{2}\right)$ \\
\hline Notebook & & Transferência e análise de dados em campo \\
\hline
\end{tabular}
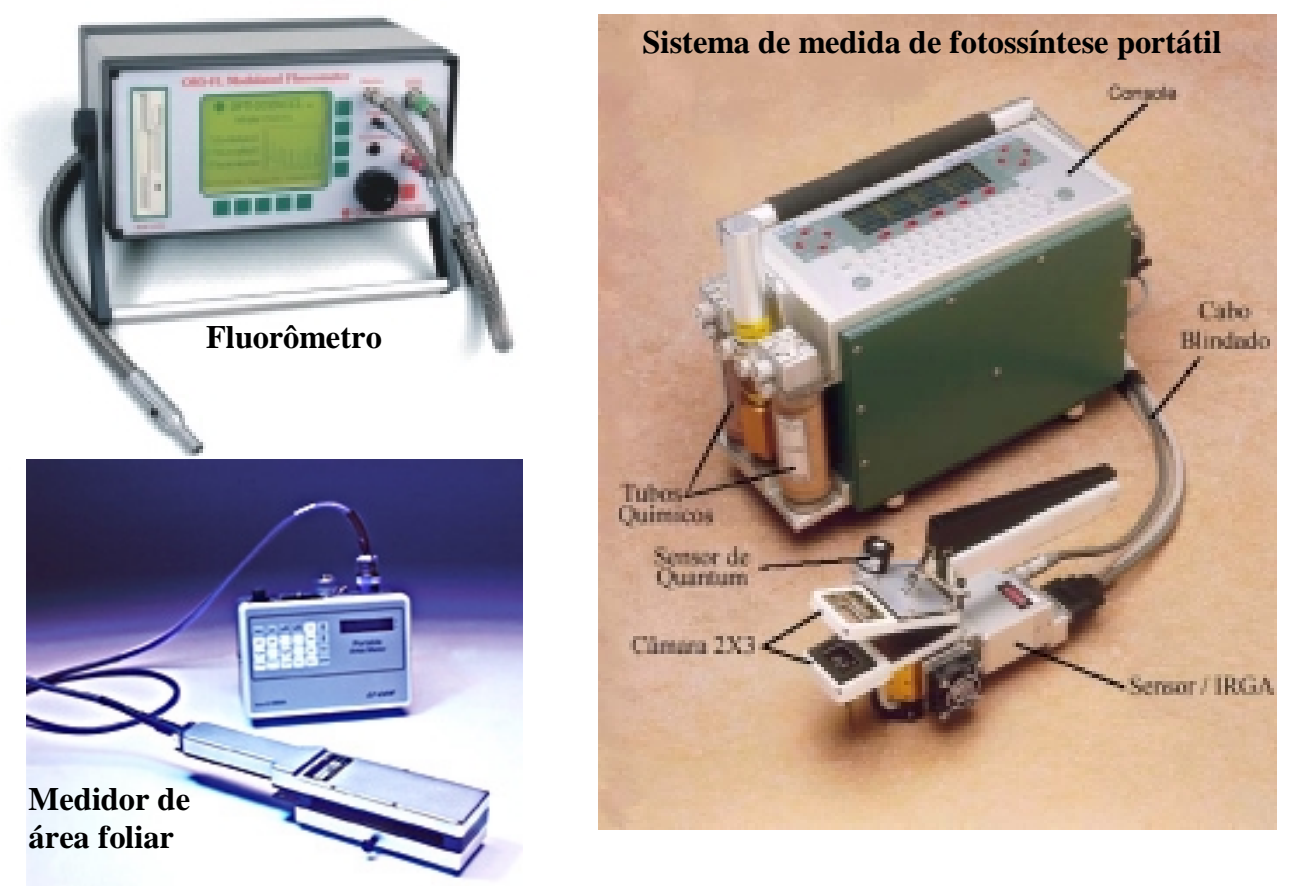

Figura 4.6 Instrumentos de medida utilizados para o sistema de monitoração, figuras adaptadas (LI-COR, 1999; LI-COR, 1998; OPTI-SCIENCES, 1998). 


\subsubsection{Procedimento para a coleta de dados}

A coleta de dados (monitoração dos sinais ambientais e fisiológicos) teve duração de um ano, tendo início em abril de 2001 e término em março de 2002. As medidas foram realizadas duas vezes por semana, isto é, dois cursos diários por semana, das 06:20 até as 18:00 horas. As medidas foram realizadas em oito plântulas, quatro plântulas para cada curso diário.

Para realizar as medidas foram considerados três níveis na plântula, como mostra a Figura 4.7. O nível I corresponde ao eófilo, o nível II corresponde à folha que se encontra no nó calculado pela equação 4.1 e o nível III corresponde à folha que se encontra abaixo do ápice. A conta dos nós realizou-se de baixo para cima.

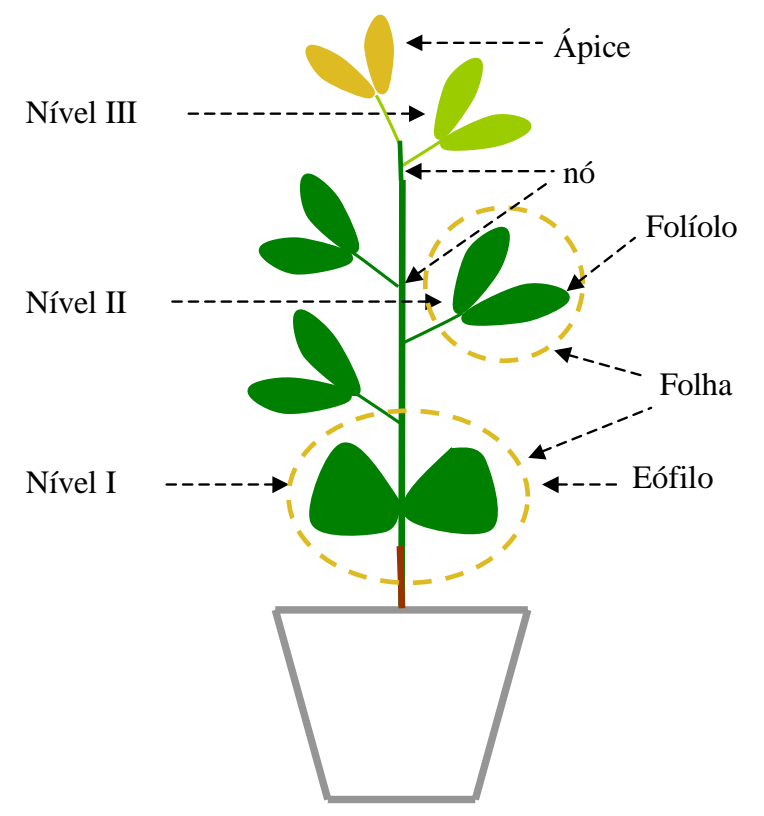

Figura 4.7 Estratificação do jatobá para a monitoração.

nó do nível II = (número total de nós/2) $+a$

Onde: $a=0, \quad$ se o número total de nós é par.

$a=0,5$, se o número total de nós é ímpar. 
O horário de medidas das variáveis fisiológicas (exceto área foliar e fluorescência) e das variáveis ambientais é mostrado na Tabela 4.2; na Tabela 4.3 é mostrado o horário das medidas de fluorescência. Num dado horário, as medidas começavam nos folíolos do primeiro nível, das quatro plântulas amostradas nesse dia; depois se passava ao segundo nível e finalmente ao terceiro nível. Como o jatobá tem folhas compostas (dois folíolos formam uma folha) num intervalo era considerado um folíolo e no outro intervalo o outro folíolo.

A área foliar das folhas amostradas era medida uma vez por mês.

Tabela 4.2 - Horário de medidas das variáveis fisiológicas (exceto área foliar e fluorescência) e variáveis ambientais.

\begin{tabular}{|l|l|l|l|l|l|l|l|l|l|l|l|}
\hline Nível & Fol.A & Fol.B & Fol.A & Fol.B & Fol.A & Fol.B & Fol.A & Fol.B & $\ldots$ & Fol.A & Fol.B \\
\hline I & $06: 20$ & $07: 10$ & $08: 10$ & $09: 10$ & $10: 10$ & $11: 10$ & $12: 10$ & $13: 10$ & $\ldots$ & $16: 10$ & $17: 10$ \\
\hline II & $06: 30$ & $07: 20$ & $08: 20$ & $09: 20$ & $10: 20$ & $11: 20$ & $12: 20$ & $13: 20$ & $\ldots$ & $16: 20$ & $17: 20$ \\
\hline III & $06: 40$ & $07: 30$ & $08: 30$ & $09: 30$ & $10: 30$ & $11: 30$ & $12: 30$ & $13: 30$ & $\ldots$ & $16: 30$ & $17: 30$ \\
\hline
\end{tabular}

Tabela 4.3 - Horário de medidas de fluorescência.

\begin{tabular}{|l|l|l|l|l|l|l|l|l|l|l|l|}
\hline Nível & Fol.A & Fol.B & Fol.A & Fol.B & Fol.A & Fol.B & Fol.A & Fol.B & $\ldots$ & Fol.A & Fol.B \\
\hline I & $06: 26$ & $07: 16$ & $08: 16$ & $09: 16$ & $10: 16$ & $11: 16$ & $12: 16$ & $13: 16$ & $\ldots$ & $16: 16$ & $17: 16$ \\
\hline II & $06: 36$ & $07: 26$ & $08: 26$ & $09: 26$ & $10: 26$ & $11: 26$ & $12: 26$ & $13: 26$ & $\ldots$ & $16: 26$ & $17: 26$ \\
\hline III & $06: 46$ & $07: 36$ & $08: 36$ & $09: 36$ & $10: 36$ & $11: 36$ & $12: 36$ & $13: 36$ & $\ldots$ & $16: 36$ & $17: 36$ \\
\hline
\end{tabular}

A seqüência básica de coleta de dados, com o medidor de fotossíntese portátil, foi como segue:

$1^{\circ}$. Preparar o medidor de fotossíntese portátil para realizar as medidas, manipulando algumas funções de controle para estabilizar parâmetros relacionados com a medida.

$2^{\circ}$. Aproximar a câmara do medidor de fotossíntese portátil à plântula para poder fechar na câmara uma parte da folha (área da câmara $6 \mathrm{~cm}^{2}$ ), na qual vai-se realizar a medida. 
$3^{\circ}$. Abrir o arquivo para salvar a medida.

$4^{\circ}$. Esperar a estabilização do instrumento segundo o procedimento indicado pelo manual (LI-COR, 1999).

Essa seqüência se repetia para cada folíolo, e demorava entre 2,5 e 3,5 minutos; como eram 4 folíolos para cada nível da plântula, em cada horário de medida eram 12 folíolos, e portanto as medidas para cada horário programado demoravam entre 30 e 42 minutos. Às vezes isso requeria um tempo maior, porque o instrumento não estabilizava, principalmente devido a fatores como a umidade muito alta e/ou presença de muitas pessoas circulando no local das medidas (casa de vegetação). Vale a pena salientar que a folha amostrada não pode ficar por muito tempo na câmara porque os estômatos fecham, além de criar um microambiente.

No manual do medidor de fotossíntese portátil, encontram-se mais detalhes sobre a calibração do instrumento e como realizar as medidas (LI-COR, 1999). Nas Figura 4.8 e Figura 4.9 apresentam-se vistas de como se realizavam as medidas com o medidor de fotossíntese portátil.

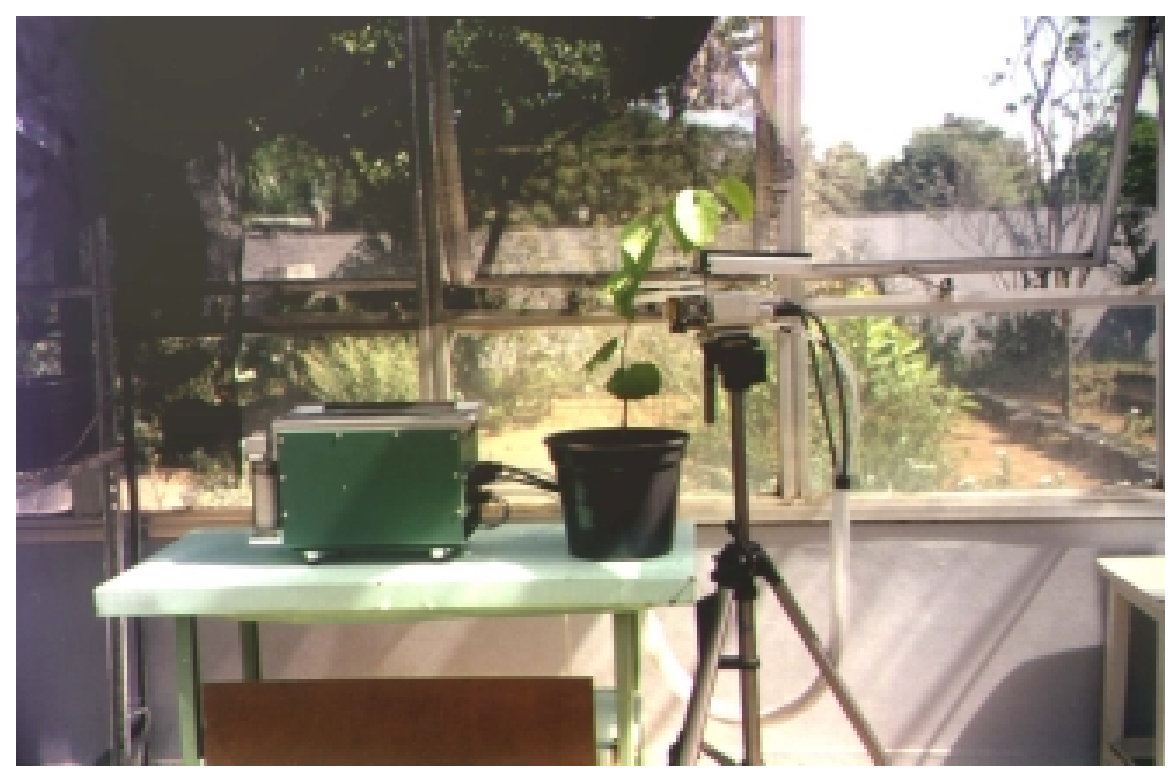

Figura 4.8 Vista de como se realizavam as medidas. 


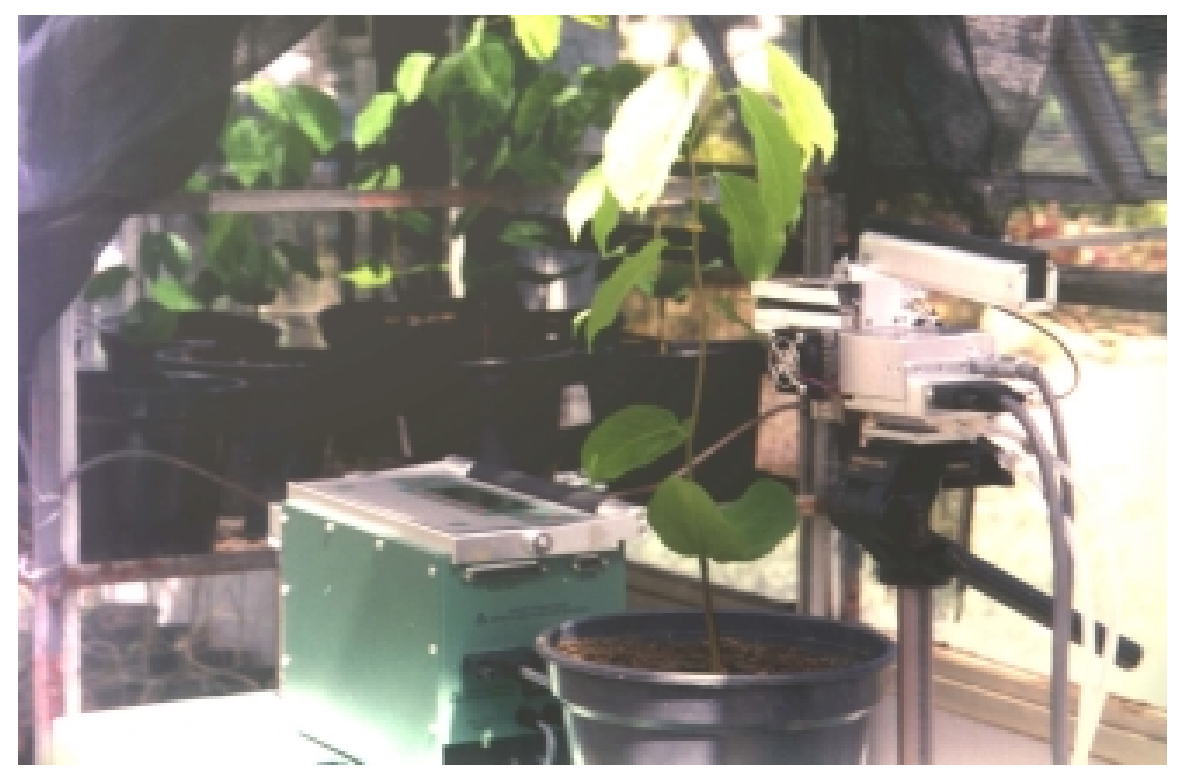

Figura 4.9 Vista em detalhe de como se realizavam as medidas.

A seqüência básica para realizar as medidas de fluorescência foi como segue:

$1^{\circ}$. A fluorescência da clorofila pode ser medida após um período de adaptação das plantas ao escuro. Para tanto, uma vez realizadas as medidas com o medidor de fotossíntese portátil, nos 4 folíolos de um nível, coloca-se um clipe, ver Figura 4.10, em cada um desses folíolos, para manter no escuro essa parte do folíolo por aproximadamente 5 minutos.

$2^{\circ}$. Transcorridos os 5 minutos, inserir a sonda no clipe, ver Figura 4.10, para incidir luz na parte do folíolo que foi submetida ao escuro.

$3^{\circ}$. Realizar a medida e retirar os grampos.

Essa sequiência repetia-se para cada nível onde se realizava a medida. O tempo requerido para as medidas de fluorescência por nível era de aproximadamente 6 minutos, portanto para os três níveis requeria-se aproximadamente 18 minutos. No manual do fluorômetro encontram-se detalhes de como realizar medidas de fluorescência (OPTI-SCIENCES, 1998). 


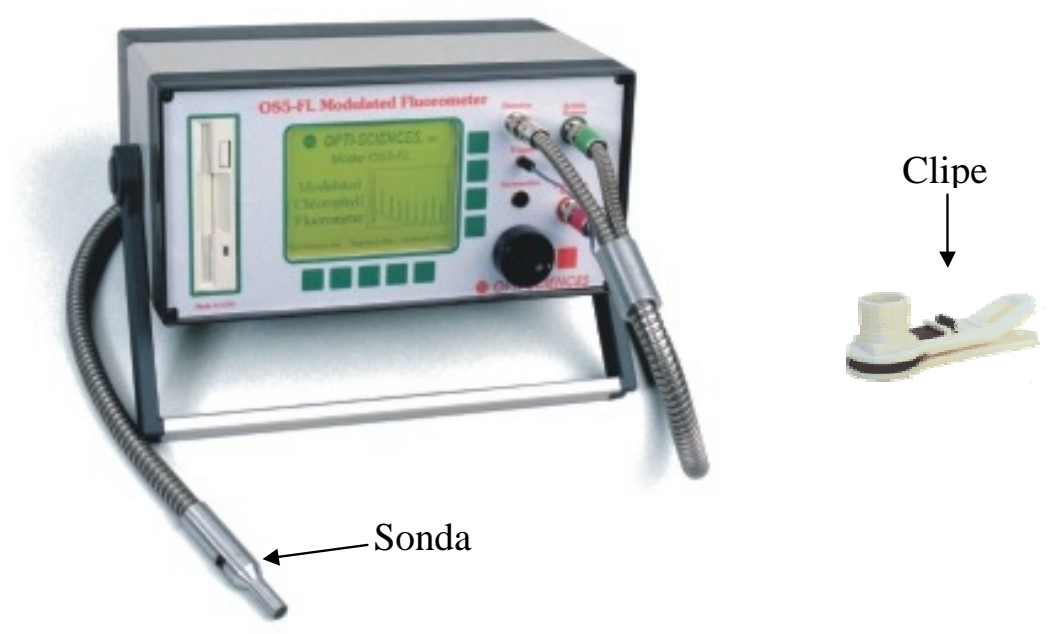

Figura 4.10 Fluorômetro e os acessórios para realizar medidas de fluorescência (OPTI-SCIENCES, 1998).

As oito plântulas de jatobá resistiram à freqüência de medidas a que foram submetidas, o que, a princípio, era motivo de preocupação. Ao iniciar-se a parte experimental elas tinham a idade de 5 meses (abril 2001), e no fim dos trabalhos (março 2002) elas tinham 1 ano e 5 meses de idade.

\subsubsection{Processamento dos dados coletados}

Os dados coletados, tanto com o medidor de fotossíntese portátil como com o fluorômetro, tiveram que ser processados. Isto é, a partir dos arquivos gerados por esses instrumentos obtiveram-se outros arquivos com os dados e o formato desejados. A seguir será explicado como foi esse processo.

Ao realizar as medidas com o medidor de fotossíntese portátil, geravam-se três arquivos para cada horário de medida, um para cada nível. Como um curso diário compreendia 12 horários de medidas, observar Tabela 4.2, no total eram gerados 36 arquivos num dia de medidas, 12 arquivos para cada nível. Na Tabela 4.4 é mostrado, como exemplo, um arquivo gerado pelo medidor de fotossíntese portátil. Nessa tabela podem ser observadas as medidas realizadas nos folíolos das 4 plântulas amostradas nesse dia, no nível 1, no horário nominal das 7:00 horas. 
Tabela 4.4 - Exemplo de um arquivo gerado pelo medidor de fotossíntese portátil.

\begin{tabular}{l}
\hline "OPEN 3.4" \\
"Mon May 28 2001 07:10:40" \\
"ComputeList=","/User/Configs/Comps/Clear Bottom EB" \\
"BLCTable=","/Sys/Lib/StdBLCTable" \\
"LightSource=","Sun+Sky",1,0.19 \\
"LogFormat=","/User/Configs/LogFormats/Std+EB" \\
"PromptList=","/User/Configs/Prompts/Default (none)" \\
"07:10:41 " \\
"Obs","Time","EBTlf","Photo","Cond","Ci","Trmmol","VpdL","Area","StmRat", \\
1,52.7,17.80,-0.0419,-86.6,396,2.48,0.0766,6,1, \\
2,164.4,18.10,0.0952,6.34,396,2.49,0.115,6,1, \\
3,280.7,17.73,0.109,-10.9,397,2.54,0.06,6,1, \\
4,402.1,17.58,0.0729,-3.12,398,2.83,0.00802,6,1, \\
"BLCond","Tair","Tleaf","TB1k","CO2R","CO2S","H2OR","H2OS","RH_R", \\
2.84,20.09,18.86,20.13,397.8,396.7,18.374,21.292,72.00, \\
2.84,20.11,19.20,20.15,398.2,396.9,18.380,21.298,71.96, \\
2.84,20.12,18.82,20.16,398.9,397.6,18.389,21.375,71.93, \\
2.84,20.13,18.79,20.17,399.9,398.4,18.396,21.720,71.91, \\
"RH_S","Flow","PARi","PARo","Press",,CsMch","HsMch","Status" \\
83.44,500.2,2,4,92.48,0.582,0.496, 111105 \\
83.38,500.2,2,4,92.48,0.582,0.496, 111105 \\
83.62,500.3,2,3,92.48,0.582,0.496, 111105 \\
84.90,500.1,3,4,92.48,0.582,0.496, 111105 \\
\end{tabular}

A partir dos arquivos gerados pelo medidor de fotossíntese geraram-se outros arquivos que contêm as medidas dos 12 horários, ou seja, as medidas de um curso diário. Dos arquivos gerados pelo medidor de fotossíntese extraíram-se as seguintes variáveis: fotossíntese (Photo), condutância estomática (Cond), transpiração (Trmmol), temperatura do ar (Tair), temperatura da folha (Tleaf), concentração de $\mathrm{CO}_{2}$ do ar $(\mathrm{CO} 2 \mathrm{R})$, concentração de $\mathrm{CO}_{2}$ da câmara $(\mathrm{CO} 2 \mathrm{~S})$, umidade relativa do ar (RH_R), umidade relativa da câmara (RH_S), radiação fotossintética ativa medida dentro da câmara (PARi), radiação fotossintética ativa medida fora da câmara (PARo). Com essas variáveis geraram-se arquivos com as medidas de um curso diário. Incluíram-se também as variáveis planta e tempo (instante da medida). $\mathrm{Na}$ Tabela 4.5 é apresentada, como exemplo, a lista parcial dos dados contidos em um desses arquivos. 
Tabela 4.5 - Exemplo de um arquivo que contém as medidas de um curso diário (lista parcial dos dados), medidas realizadas com o medidor de fotossíntese.

\begin{tabular}{|c|c|c|c|c|c|c|c|c|c|c|c|c|}
\hline Planta & Tempo & Fotossint & CondEstom & Transpirac & TempAr & Tempfol & CO2ar & $\mathrm{CO} 2 \mathrm{cam}$ & UmiRelAr & UmiRelCam & PARi & PARo \\
\hline 1 & 6.700 & 0.047 & 1.270 & 1.860 & 19.740 & 18.940 & 398.100 & 397.200 & 73.320 & 82.100 & 0.000 & 1.000 \\
\hline 2 & 6.729 & 0.125 & 4.810 & 2.170 & 19.770 & 18.700 & 397.800 & 396.600 & 73.240 & 83.470 & 0.000 & 1.000 \\
\hline 3 & 6.758 & 0.289 & -4.370 & 2.480 & 19.780 & 18.420 & 397.500 & 396.000 & 73.190 & 84.810 & 0.000 & 1.000 \\
\hline 4 & 6.786 & 0.208 & -2.660 & 2.510 & 19.800 & 18.160 & 397.300 & 395.900 & 73.080 & 84.840 & 0.000 & 1.000 \\
\hline 1 & 7.193 & -0.042 & -86.600 & 2.480 & 20.090 & 18.860 & 397.800 & 396.700 & 72.000 & 83.440 & 2.000 & 4.000 \\
\hline 2 & 7.224 & 0.095 & 6.340 & 2.490 & 20.110 & 19.200 & 398.200 & 396.900 & 71.960 & 83.380 & 2.000 & 4.000 \\
\hline 3 & 7.256 & 0.109 & -10.900 & 2.540 & 20.120 & 18.820 & 398.900 & 397.600 & 71.930 & 83.620 & 2.000 & 3.000 \\
\hline 4 & 7.290 & 0.073 & -3.120 & 2.830 & 20.130 & 18.790 & 399.900 & 398.400 & 71.910 & 84.900 & 3.000 & 4.000 \\
\hline$\ldots$ & $\ldots$ & $\ldots$ & $\ldots$ & $\ldots$ & $\ldots$ & $\ldots$ & $\ldots$ & $\ldots$ & $\ldots$ & $\ldots$ & $\ldots$ & $\ldots$ \\
\hline 1 & 17.179 & -0.296 & 0.006 & 0.110 & 27.230 & 26.770 & 382.300 & 382.600 & 51.520 & 51.850 & 1.000 & 2.000 \\
\hline 2 & 17.205 & -0.447 & 0.007 & 0.121 & 27.180 & 26.700 & 382.400 & 382.900 & 51.650 & 52.010 & 1.000 & 2.000 \\
\hline 3 & 17.228 & -0.441 & 0.005 & 0.085 & 27.130 & 26.630 & 382.500 & 383.000 & 51.740 & 51.990 & 1.000 & 1.000 \\
\hline 4 & 17.254 & -0.410 & 0.004 & 0.064 & 27.080 & 26.610 & 382.800 & 383.300 & 51.930 & 52.120 & 1.000 & 2.000 \\
\hline
\end{tabular}


A variável planta identifica as plântulas em que foram realizadas as medidas, como foi mencionado no item 4.1.4. O valor, em decimal, da variável tempo (instante da medida) foi calculado a partir da variável "time", da hora em que começava a medida, que se encontra no arquivo gerado pelo medidor de fotossíntese.

Uma vez gerados os arquivos com as medidas por curso diário (por dia de medida) para os três níveis, foram gerados outros arquivos com as medidas para cada estação (outono, inverno, primavera, verão), também para os três níveis. As variáveis que esses arquivos contêm são as mesmas dos arquivos com medidas por curso diário.

Ao realizar as medidas com o fluorômetro gerava-se um arquivo para cada horário de medida, onde eram registradas as medidas realizadas nos três níveis. Nestas medidas um curso diário também compreendia 12 horários de medidas, observar a Tabela 4.3, pelo que se geravam 12 arquivos num dia de medidas. $\mathrm{Na}$ Tabela 4.6 é apresentado, como exemplo, um arquivo gerado pelo fluorômetro. Nessa tabela podem ser observadas as medidas realizadas nos folíolos das 4 plântulas amostradas nesse dia, nos três níveis, no horário das 6:00 horas. Cada coluna dessa tabela, separada por vírgula, representa uma variável. Por exemplo, a primeira coluna indica o tipo de medida realizada, a segunda coluna indica o número desse arquivo, a terceira coluna o número da amostra medida, as seguintes 5 colunas fornecem informação de data e hora de medida, e as colunas restantes fornecem informação das medidas de fluorescência.

A partir dos arquivos gerados pelo fluorômetro geraram-se outros arquivos que contêm as medidas de um curso diário. Na Tabela 4.7 é mostrado como exemplo um arquivo que contém as medidas (lista parcial dos dados) de um curso diário. Do arquivo gerado pelo fluorômetro extraíram-se as variáveis Fo (Fluorescência inicial), Fv (Fluorescência variável), Fm (Fluorescência máxima) e Fv/Fm. A variável planta foi gerada para identificar as plântulas nas quais foram realizadas as medidas. A variável tempo (instante da medida) foi gerada a partir dos dados do arquivo gerado pelo fluorômetro. O valor dessa variável está em decimal. 
Tabela 4.6 - Exemplo de um arquivo gerado pelo fluorômetro.

\begin{tabular}{|l|}
\hline $129,1,1,6,8,6,38,26,40,80,250, .8,0,172,687,859, .799, .0$ \\
$129,1,2,6,8,6,38,45,40,80,250, .8,0,135,635,770, .824, .0$ \\
$129,1,3,6,8,6,38,57,40,80,250, .8,0,151,697,848, .821, .0$ \\
$129,1,4,6,8,6,39,10,40,80,250, .8,0,165,675,840, .803, .0$ \\
$129,1,5,6,8,6,46,43,40,80,250, .8,0,122,545,667, .817, .0$ \\
$129,1,6,6,8,6,46,52,40,80,250, .8,0,117,522,639, .816, .0$ \\
$129,1,7,6,8,6,47,3,40,80,250, .8,0,125,592,717, .825, .0$ \\
$129,1,8,6,8,6,47,13,40,80,250, .8,0,131,492,623, .789, .0$ \\
$129,1,9,6,8,6,55,55,40,80,250, .8,0,108,536,644, .832, .0$ \\
$129,1,10,6,8,6,56,7,40,80,250, .8,0,117,538,655, .821, .0$ \\
$129,1,11,6,8,6,56,18,40,80,250, .8,0,118,557,675, .825, .0$ \\
$129,1,12,6,8,6,56,30,40,80,250, .8,0,120,465,585, .794, .0$ \\
\hline
\end{tabular}

Tabela 4.7 - Exemplo de um arquivo que contém as medidas de um curso diário, lista parcial dos dados, medidas realizadas com o fluorômetro.

\begin{tabular}{|llcccl|}
\hline Planta & Tempo & Fo & Fv & Fm & Fv/Fm \\
5 & 6.641 & 172.000 & 687.000 & 859.000 & 0.799 \\
6 & 6.646 & 135.000 & 635.000 & 770.000 & 0.824 \\
7 & 6.649 & 151.000 & 697.000 & 848.000 & 0.821 \\
8 & 6.653 & 165.000 & 675.000 & 840.000 & 0.803 \\
5 & 7.325 & 133.000 & 527.000 & 660.000 & 0.798 \\
6 & 7.327 & 138.000 & 503.000 & 641.000 & 0.784 \\
7 & 7.331 & 137.000 & 525.000 & 662.000 & 0.793 \\
8 & 7.333 & 147.000 & 489.000 & 636.000 & 0.768 \\
$\ldots$ & $\ldots$ & $\ldots$ & $\ldots$ & $\ldots$ & $\ldots$ \\
5 & 15.317 & 374.000 & 1447.000 & 1821.000 & 0.794 \\
6 & 15.320 & 376.000 & 1379.000 & 1755.000 & 0.785 \\
7 & 15.324 & 366.000 & 1380.000 & 1746.000 & 0.790 \\
8 & 15.327 & 460.000 & 1452.000 & 1912.000 & 0.759 \\
5 & 16.284 & 387.000 & 1449.000 & 1836.000 & 0.789 \\
6 & 16.288 & 369.000 & 1369.000 & 1738.000 & 0.787 \\
7 & 16.291 & 400.000 & 1358.000 & 1758.000 & 0.772 \\
8 & 16.295 & 430.000 & 1475.000 & 1905.000 & 0.774 \\
5 & 17.287 & 391.000 & 1587.000 & 1978.000 & 0.802 \\
6 & 17.290 & 392.000 & 1609.000 & 2001.000 & 0.804 \\
7 & 17.293 & 415.000 & 1619.000 & 2034.000 & 0.795 \\
8 & 17.296 & 479.000 & 1568.000 & 2047.000 & 0.765 \\
\hline
\end{tabular}

De igual maneira que para o medidor de fotossíntese, uma vez gerados os arquivos com as medidas por curso diário, para cada um dos três níveis, foram gerados outros arquivos com as medidas para cada estação (outono, inverno, primavera, verão) e para cada nível. 
Para gerar os arquivos, por curso diário e por estação, tiveram que ser elaborados programas, os quais foram implementados na linguagem $\mathrm{C}$.

\subsubsection{Considerações finais}

Embora não tenham ocorrido problemas graves no que diz respeito às medidas realizadas utilizando o sistema de medida de fotossíntese portátil, que comprometessem a essência do trabalho, algumas dificuldades foram encontradas e puderam ser superadas ou contornadas.

A primeira foi com o curso diário de medida. Inicialmente as medidas eram realizadas de 6:20 a 18:00h. Posteriormente, devido ao problema de racionamento de energia elétrica que se enfrentou em 2001, o ingresso ao Instituto só era permitido a partir das 7:00 horas, pelo que as medidas começavam às 7:20h. Portanto, desde o final de junho até começo de outubro perderam-se as medidas das 6:20h. Como em outubro inicia-se o horário de verão, as medidas eram realizadas de 7:20 a 18:00h, horário de verão, que na realidade correspondiam a 6:20 e 17:00 horas.

A segunda dificuldade foi com as medidas de fluorescência: perderam-se medidas desta variável a partir de final de novembro de 2001, ou seja, parte das medidas de primavera e completamente as de verão. Isto devido a problemas técnicos com o fluorômetro, que se danificou, foi enviado para ser consertado e infelizmente não retornou a tempo para se continuar realizando as medidas.

A terceira dificuldade foi com o medidor de área foliar portátil. Este instrumento não funcionava adequadamente, razão pela qual foi enviado para ser calibrado várias vezes. Por esses problemas perderam-se medidas de área foliar.

Uma dificuldade, já esperada, foi comprovada e superada: esta etapa da pesquisa foi extremamente laboriosa devido à frequiência com que foram realizadas as medidas em campo. Essa atividade ocupava todo o dia, sem intervalos para qualquer atividade. Devido aos cuidados que o equipamento e as medidas 
demandavam, todo o trabalho foi feito pela autora, eventualmente com a ajuda da técnica do Instituto de Botânica (IB), Ana Maria Baroni. Embora cansativo e demandante esse trabalho permitiu obter uma quantidade de dados bastante grande, valiosa e de qualidade, dados das quatro estações do ano, numa seqüência provavelmente inédita segundo os pesquisadores do IB, certamente inédita ao menos para o jatobá. No capítulo 5, resultados e discussão, poderá apreciar-se-á a relevância desta coleta de dados.

\subsection{Modelagem de fotossíntese com redes neurais artificiais}

Nesta etapa da pesquisa foi realizada a modelagem do ciclo diário de fotossíntese, no nível da folha, com os dados coletados. A técnica aplicada foi redes neurais artificiais.

Como foi visto no capítulo 2, modelar fluxo e troca de $\mathrm{CO}_{2}$ com técnicas convencionais é dificultoso, devido à diversidade e à não linearidade das variáveis envolvidas.

Técnicas não convencionais tais como redes neurais artificiais dão a possibilidade de lidar com problemas não lineares. Existem diferentes modelos de ANNs: MLPs (Multilayer perceptron), SOM (Self Organizing Map), redes CP (Counter Propagation Nets), redes BAM (Bidirectional Associative Memories), a arquitetura ART (Adaptive Resonance Theory), etc. Esses modelos são usados dependendo da aplicação: interpolação, classificação, processamento de sinais, reconhecimento de padrões, etc. Neste caso, como o objetivo é modelar (interpolar) fotossíntese, foi utilizado o popular modelo Multilayer perceptron, por ser o mais usado para propósitos de interpolação, com algoritmo de treinamento backpropagation, conhecido também como regra delta generalizada.

Para atingir o objetivo de modelar o ciclo diário de fotossíntese, com a técnica de redes neurais, foram realizadas as seguintes etapas: 
a) Fitomonitoração (coleta de dados)

b) Preparo dos conjuntos de dados para o treinamento e o teste

c) Definição da topologia da rede e dos parâmetros de treinamento

d) Treinamento das ANNs

e) Teste (validação) das ANNs

Essas etapas serão tratadas a seguir, exceto a etapa "a", fitomonitoração, que foi explicada no item 4.1 .

\subsubsection{Preparo dos conjuntos de dados para o treinamento e o teste}

Tanto para o treinamento como para o teste da rede neural MLP são utilizados conjuntos de dados formados por pares de vetores de entrada-saída.

Os dados coletados, variáveis ambientais e variáveis fisiológicas, foram usados para formar os conjuntos de dados para o treinamento e teste; $65 \%$ dos dados foram destinados para o treinamento e $35 \%$ para o teste.

Como a fotossíntese depende de fatores extrínsecos (variáveis ambientais) e intrínsecos (fatores relacionados com a planta), a fotossíntese foi considerada como a variável dependente e as variáveis ambientais como independentes.

Por tanto, neste trabalho de pesquisa, o vetor de saída foi formado pela variável fisiológica fotossíntese, e o vetor de entrada foi constituído pelas variáveis ambientais, além de tempo (instante de medida), planta e estação. A variável planta identificou a plântula na qual foi realizada a medida: os números 1 a 8 identificaram as plântulas. A variável estação indicou a época na qual foi realizada a medida; os números 1, 2, 3 e 4 representaram o outono, o inverno, a primavera e o verão, respectivamente. Essas variáveis são apresentadas na Tabela 4.8, na qual as variáveis de entrada são indicadas com suas respectivas abreviaturas, as que serão usadas posteriormente. 
No item 4.1.5, processamento dos dados coletados, foi explicado que os dados foram agrupados por estações. Isto é, obtiveram-se arquivos de dados para cada uma das estações (outono, inverno, primavera e verão), e para cada nível da plântula onde se realizou a medida. Com base nesses arquivos e na Tabela 4.8 foram montados os arquivos de treinamento e teste, os quais estão constituídos pelos pares de vetores de entrada e saída.

Antes de separar os conjuntos de dados em arquivos de treinamento e teste, os dados, pares de vetores entrada-saída, foram ordenados aleatoriamente, para evitar que a rede tenha tendência a aprender na seqüência de apresentação.

Tabela 4.8 - Variáveis de entrada e saída utilizadas no treinamento e no teste das ANNs.

\begin{tabular}{|c|c|c|}
\hline \multicolumn{2}{|l|}{ Variáveis de entrada } & \multirow{2}{*}{$\begin{array}{l}\text { Variável } \\
\text { de saída }\end{array}$} \\
\hline Nome & Abreviatura & \\
\hline 1. Tempo & Tempo & Fotossíntese \\
\hline 2. Estação & Est & \\
\hline 3. Planta & Planta & \\
\hline 4. Temperatura do ar & Tar & \\
\hline 5. Temperatura da folha & Tfol & \\
\hline 6. Concentração de $\mathrm{CO}_{2}$ do ar & $\mathrm{CO}_{2}$ ar & \\
\hline 7. Concentração de $\mathrm{CO}_{2}$ na câmara & $\mathrm{CO}_{2} \mathrm{câ}$ & \\
\hline 8. Umidade relativa do ar & Umiar & \\
\hline 9. Umidade relativa na câmara & Umicâ & \\
\hline 10. Radiação Fotossintética Ativa na câmara & PARi & \\
\hline 11. Radiação Fotossintética Ativa fora da câmara & PARo & \\
\hline
\end{tabular}

Na Tabela 4.9 é apresentado, como exemplo, a lista parcial de um arquivo de treinamento; nessa lista pode-se observar o par de vetores entrada-saída. O arquivo 
de treinamento apresentado corresponde à estação de outono, e às medidas realizadas no nível 1.

Tabela 4.9 - Lista parcial de um arquivo de treinamento.

\begin{tabular}{|r|r|l|l|r|r|r|r|r|r|r|}
\hline \multicolumn{10}{|c|}{ Entradas } & Saída \\
\hline Tempo & Planta & Tar & Tfol & $\mathbf{C O}_{2} \mathbf{a r}$ & $\mathbf{C O}_{2} \mathbf{c a ̂}$ & Umiar & Umicâ & PARi & PARo & Fotossín \\
\hline 15.295 & 3 & 31.98 & 31.48 & 403.2 & 403.4 & 40.96 & 41.95 & 5 & 9 & -0.34 \\
\hline 9.235 & 3 & 20.18 & 19.08 & 401.7 & 400.9 & 72.2 & 80.09 & 5 & 6 & -0.06 \\
\hline 12.252 & 7 & 25.08 & 24.71 & 383.5 & 381.1 & 33.49 & 35.83 & 27 & 167 & 1.69 \\
\hline 10.184 & 5 & 28.29 & 27.62 & 421.6 & 419.3 & 52.1 & 54.95 & 30 & 108 & 1.43 \\
\hline 8.537 & 4 & 26.59 & 26.11 & 388.9 & 387.7 & 61.53 & 63.21 & 11 & 21 & 0.77 \\
\hline 10.364 & 5 & 26.94 & 26.45 & 375.6 & 373.3 & 57.61 & 59.31 & 34 & 61 & 1.70 \\
\hline 18.148 & 8 & 26.36 & 26.02 & 367.7 & 368.2 & 57.34 & 57.35 & 0 & 0 & -0.37 \\
\hline 10.215 & 1 & 25.56 & 24.66 & 371.8 & 369.4 & 52.17 & 56.79 & 30 & 43 & 1.78 \\
\hline 11.199 & 6 & 24.14 & 23.63 & 374.1 & 373.4 & 62.74 & 63.9 & 10 & 13 & 0.51 \\
\hline 16.221 & 6 & 26.06 & 25.51 & 375.4 & 375.3 & 36.51 & 37.17 & 5 & 8 & 0.05 \\
\hline 10.212 & 3 & 31.98 & 31.48 & 403.2 & 403.4 & 40.96 & 41.95 & 5 & 9 & -0.34 \\
\hline 8.459 & 2 & 26.56 & 26.09 & 388.1 & 387.2 & 61.73 & 62.77 & 10 & 17 & 0.59 \\
\hline
\end{tabular}

\subsubsection{Definição da arquitetura da rede e parâmetros de treinamento}

Como o modelo adotado, nesta pesquisa, é o multilayer perceptron (MLP), com algoritmo de treinamento backpropagation, a arquitetura, ou estrutura, da rede é multicamada.

Neste trabalho de pesquisa, o número de camadas variou entre três e quatro, sendo uma a camada de entrada, uma ou duas a(s) camada(s) escondida(s) e uma a camada de saída. O número de neurônios da camada de entrada variou de seis até dez, dependendo do número de variáveis de entrada utilizadas, as quais foram apresentadas na Tabela 4.8. O número de neurônios da(s) camada(s) escondida(s) foi determinado experimentalmente, no processo de treinamento das redes neurais. $\mathrm{O}$ 
número de neurônios da camada de saída foi um, correspondente à variável de saída fotossíntese.

Na Figura 4.11 é mostrada, como exemplo, uma estrutura de rede, na qual se observam três camadas; a camada de entrada com 6 neurônios, onde são apresentadas 6 variáveis ambientais; uma camada escondida com 8 neurônios; e a camada de saída com um neurônio que corresponde à fotossíntese.

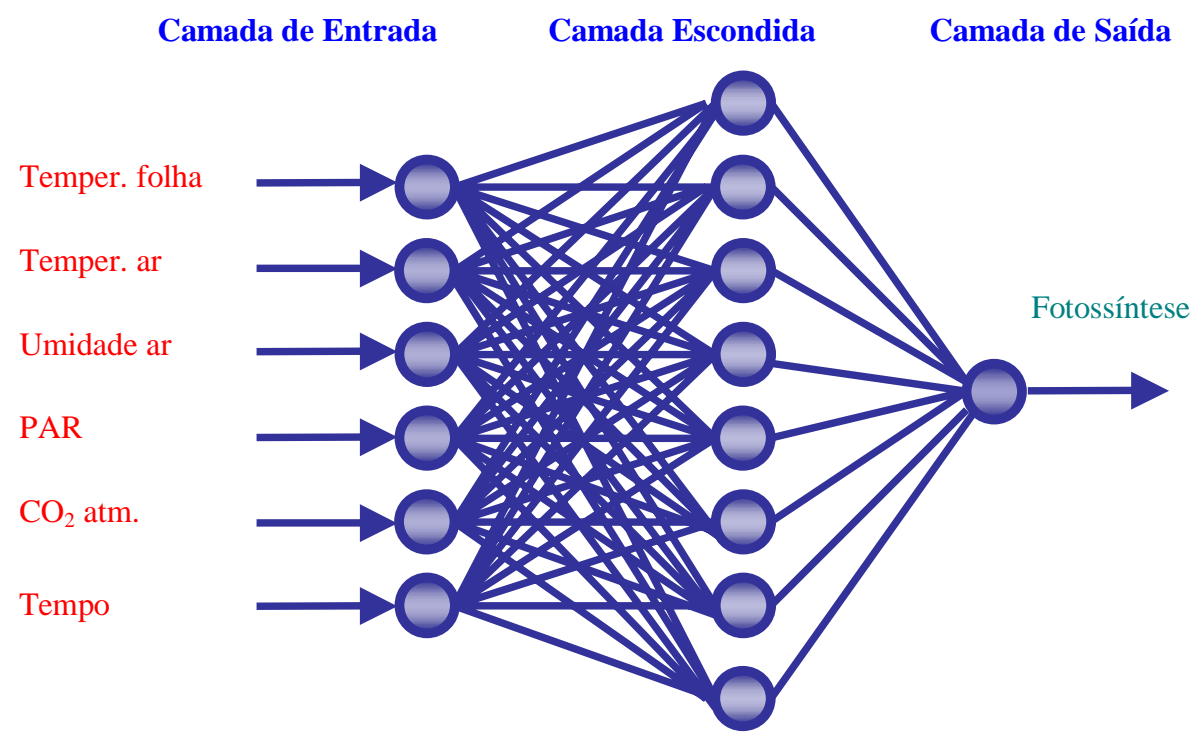

Figura 4.11 Estrutura de rede MLP utilizada para modelar fotossíntese.

Além de definir a estrutura da rede, devem ser definidos os parâmetros de treinamento da rede, os quais estão relacionados com o algoritmo de treinamento, neste caso backpropagation, e com o programa no qual foi implementado o algoritmo. Os parâmetros que foram usados nesta pesquisa são apresentados na Tabela 4.10. Na etapa do treinamento, a maioria dos parâmetros receberam valores variáveis, indicados na Tabela 4.10, exceto o coeficiente para a suavização exponencial (exponential smoothing), que foi mantido com o mesmo valor. 
Tabela 4.10 - Parâmetros de treinamento utilizados nesta pesquisa.

\begin{tabular}{|l|c|c|}
\hline \multicolumn{1}{|c|}{ Parâmetros } & $\begin{array}{c}\text { Símbolo ou } \\
\text { abreviatura }\end{array}$ & Valores definidos \\
\hline 1. Coeficiente para a suavização exponencial & $\alpha$ & 0,92 \\
\hline 2. Coeficiente de aprendizado ou treinamento & $\eta$ & $0,75 \leq \eta \leq 1$ \\
\hline 3.Tolerância de erro & $\varepsilon$ & 0,01 e 0,001 \\
\hline 4. Número de iterações globais & NIG & 3000 e 6000 \\
\hline 5. Número de iterações internas & NII & 3 e 5 \\
\hline
\end{tabular}

\subsubsection{Treinamento das ANNs}

Uma vez montado o arquivo de treinamento, e definidos a estrutura da rede e os parâmetros de treinamento, o passo seguinte é o treinamento da rede, no qual são ajustados os pesos das conexões da rede. Isto é, as conexões entre os neurônios da rede são associadas com pesos, e no processo do treinamento esses pesos são ajustados utilizando o conjunto de dados, formados pelos vetores entrada-saída.

Antes de começar o treinamento os pesos devem ser iniciados com valores aleatórios pequenos, dentro de uma faixa determinada, para evitar que a rede se sature. Nesta pesquisa, a faixa de valores iniciais foi definida entre -0,01 e 0,01 .

O programa utilizado para o treinamento foi o MLP1b, implementado na linguagem C. Este programa foi desenvolvido pelo Prof. Dr. Hernán Prieto Schmidt, professor do Departamento de Energia e Automação Elétrica, PEA, da POLI-USP.

Para avaliar o desempenho da rede, o programa MLP1b calcula o erro pela equação 4.2 .

$$
\text { Erro }=a b s\left(\frac{V C-V R}{V R}\right)
$$


Onde $\quad V C$ : Valor de saída calculado pela rede

$V R$ : Valor de referência (valor de saída real)

Na Tabela 4.11 é apresentada uma lista parcial dos resultados de um treinamento, com 8 variáveis de entrada. Nessa tabela, observam-se as variáveis de entrada, a variável de saída real e a variável de saída calculada pela rede.

Como exemplo, calcula-se o erro de avaliação do primeiro par de vetores entrada-saída, apresentados na Tabela 4.11.

$$
\begin{aligned}
& \text { Valor de saída real }=-0,34000 \\
& \text { Valor de saída calculado }=-0,33569 \\
& \text { Erro }=a b s\left(\frac{-0,33569-(-0,34000)}{-0,34000}\right)=0,0127=1,27 \%
\end{aligned}
$$

\begin{tabular}{|c|c|}
\hline & Par de vetores entrada-saída \\
\hline Entrada & $\begin{array}{llllllll}15.295 & 31.980 & 31.480 & 403.200 & 403.400 & 40.960 & 41.950 & 5.000\end{array}$ \\
\hline Saída R & -0.34000 \\
\hline Saída C & -0.33569 \\
\hline Entrada & 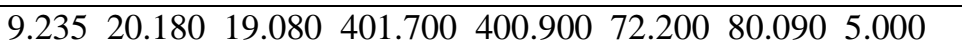 \\
\hline Saída R & -0.06000 \\
\hline Saída C & -0.02989 \\
\hline Entrada & $\begin{array}{llllllll}12.252 & 25.080 & 24.710 & 383.500 & 381.100 & 33.490 & 35.830 & 27.000\end{array}$ \\
\hline Saída R & 1.69000 \\
\hline Saída C & 1.73717 \\
\hline Entrada & $10.184 \quad 28.290 \quad 27.620 \quad 421.600 \quad 419.300 \quad 52.100 \quad 54.950 \quad 30.000$ \\
\hline Saída R & 1.43000 \\
\hline Saída C & 1.45585 \\
\hline
\end{tabular}

Tabela 4.11 - Lista parcial dos resultados de um treinamento de rede neural.

Outro ponto a mencionar nesta parte é o tempo de treinamento. Este depende da complexidade do problema, da função que se modela, da estrutura de rede, dos 
parâmetros de treinamento, do número de dados para o treinamento, dos dados de entrada que são fornecidos à rede, entre outros.

\subsubsection{Teste (validação) das ANNs}

Uma vez treinada a rede neural, o próximo passo é testar a rede treinada, com o propósito de avaliar sua capacidade de generalização. Isto é, se a rede treinada é capaz de gerar respostas adequadas, para entradas que não lhe foram apresentadas durante o treinamento.

Nesta etapa, dentre as redes treinadas, as que apresentaram melhores resultados foram avaliadas com o conjunto de dados separados para este propósito. 


\section{RESULTADOS E DISCUSSÃO}

Neste capítulo serão apresentados e discutidos os resultados da pesquisa realizada. Primeiro tratar-se-á da fitomonitoração e da continuação da modelagem de fotossíntese com redes neurais artificiais.

\subsection{Resultados e discussão da fitomonitoração (coleta de dados)}

A fitomonitoração, realizada durante o período de um ano, proporcionou informação importante acerca do comportamento fisiológico do jatobá, no que se refere à fotossíntese, à condutância estomática e à transpiração, além das variáveis ambientais e fluorescência que mostram quais eram as condições em que se encontravam as plântulas no momento das medidas. Neste item, os resultados dessa fitomonitoração serão apresentados e analisados.

Tanto os dados fisiológicos como os dados ambientais serão apresentados e analisados com respeito ao tempo (instante de medida). Primeiro tratar-se-á das variáveis fisiológicas e em seguida das variáveis ambientais. A análise e discussão serão realizadas baseadas na observação gráfica das quatro estações e dos três níveis das plântulas (medidas realizadas nas partes inferior, média e superior das plântulas).

Os gráficos foram elaborados com o ORIGIN 6.0, um software que oferece uma vasta gama de ferramentas para análise, tais como ajuste de curvas (linear e não linear), estatística, entre outros, assim como diversas alternativas para elaborar gráficos. Também permite importar dados de outros softwares, ou importar dados que estão em código ASCII. 


\subsubsection{Resultados e análise das variáveis fisiológicas}

Como foi mencionado no item 4.1, as variáveis fisiológicas medidas nas plântulas de jatobá foram: fotossíntese líquida, condutância estomática, taxa de transpiração, fluorescência e temperatura da folha. Nas figuras seguintes, desde a Figura 5.1 até a Figura 5.5, são apresentados os resultados das medidas dessas variáveis. Nessas figuras são mostrados gráficos das variáveis fisiológicas em função do tempo (instante da medida), das quatro estações, exceto na Figura 5.4, medidas de fluorescência, que mostra três estações pelos motivos explicados no item 4.1.6. Nesses gráficos, os pontos azuis são as medidas realizadas nas folhas do nível 1, parte inferior da plântula; os pontos verdes correspondem ao nível 2, medidas realizadas no meio da plântula; e os pontos vermelhos são as medidas realizadas no nível 3, parte superior da plântula.

Na Figura 5.1 são mostrados os gráficos do ciclo diário da fotossíntese líquida. Observando esses gráficos notam-se diferenças entre cada estação nos horários em que a fotossíntese atinge os maiores e os menores valores. Para ilustrar melhor essas diferenças foi elaborada a Tabela 5.1 a partir dos dados coletados e da Figura 5.1. Nessa tabela indica-se em que horários o jatobá atinge os maiores e os menores valores de fotossíntese, nas quatro estações do ano. No outono e no inverno o jatobá começa a realizar fotossíntese mais tarde, enquanto que na primavera e no verão ele começa mais cedo. No outono atinge os maiores valores entre 11 e 12 horas, no inverno entre 11 e 13 horas, na primavera entre 8 e 10 horas e no verão entre 9 e 13 horas.

Outra característica que se observa é que alguns valores de fotossíntese tornam-se negativos significativamente, provavelmente devido à fotorrespiracão, a partir das 14 horas, no outono, no inverno e na primavera, e no verão a partir das 13 horas; mas também observam-se valores positivos de fotossíntese. Essa variação de valores mostra que houve dias em que as plântulas realizavam fotossíntese, e dias em que houve fotorrespiração. Por exemplo, no verão observa-se que às 13 horas a 
fotossíntese varia de -1 a $3 \mu \mathrm{mol} \mathrm{CO} 2 \cdot \mathrm{m}^{-2} \cdot \mathrm{s}^{-1}$, ver Figura 5.1 e Tabela 5.1 (na quarta linha da tabela).
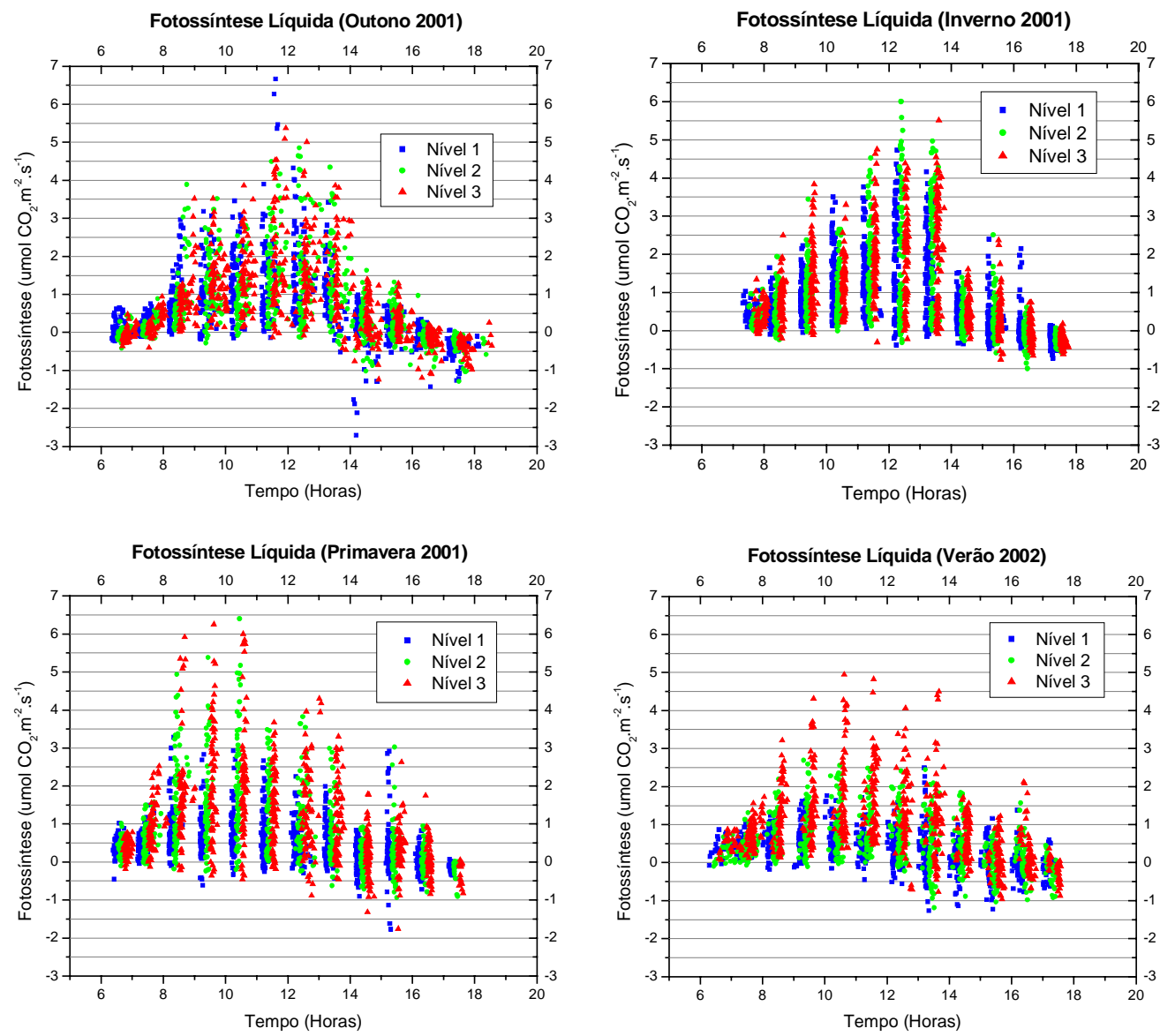

Figura 5.1 Medidas de fotossíntese líquida das quatro estações.

Na Figura 5.1, nota-se também que, nas quatro estações, às 14 horas há uma queda abrupta da fotossíntese. Após essa queda há um ligeiro aumento de fotossíntese, no inverno e na primavera às 15 horas, e no verão às 16 horas. Essa queda de fotossíntese às 14 horas poderia ser explicada por uma diminuição da radiação incidente nesse horário. Procurou-se observar os gráficos de radiação, Figura 5.9 e Figura 5.12, e identificou-se a ocorrência desse fato. A explicação para essa situação inusitada foi obtida no local do experimento, pois se pôde constatar que, nesse horário, ocorria um sombreamento sobre as plântulas de jatobá, causado por uma viga na casa de vegetação. Certamente essa é uma situação à qual estão sujeitas as plantas dentro da floresta. 
Tabela 5.1 - Características da fotossíntese no jatobá das quatro estações do ano.

\begin{tabular}{|c|c|c|c|c|}
\hline Características da fotossíntese & Outono & Inverno & Primavera & Verão \\
\hline $\begin{array}{l}\text { Fotossíntese às } 6 \text { horas } \\
\text { em } \mu \mathrm{mol} \mathrm{CO} \mathrm{CO}_{2} \cdot \mathrm{m}^{-2} \cdot \mathrm{s}^{-1}\end{array}$ & $\begin{array}{lll}\text { De } & -0,4 & a \\
0,6 & & \end{array}$ & \begin{tabular}{|c|} 
Não \\
disponível*
\end{tabular} &, 2 a 0,9 & $\begin{array}{lll}\text { De } & -0,1 & \text { a } \\
0,8 & & \end{array}$ \\
\hline $\begin{array}{l}\text { Fotossíntese às } 7 \text { horas } \\
\text { em } \mu \mathrm{mol} \mathrm{CO} \mathrm{CO}_{2} \cdot \mathrm{m}^{-2} \cdot \mathrm{s}^{-1}\end{array}$ & $\begin{array}{lll}\text { De } & -0,25 & \text { a } \\
0,8 & & \end{array}$ & $\begin{array}{|lll|}\text { De } & -0,2 & \text { a } \\
1,2 & & \\
\end{array}$ & De $-0,1$ & $\begin{array}{lll}\text { De } & -0,1 & \text { a } \\
1,7 & & \end{array}$ \\
\hline $\begin{array}{l}\text { Horário em que atingem os maiores } \\
\text { valores de fotossíntese e faixa de } \\
\text { variação } \\
\text { em } \mu \mathrm{mol} \mathrm{CO}_{2} \cdot \mathrm{m}^{-2} \cdot \mathrm{s}^{-1}\end{array}$ & $\begin{array}{l}11 \text { e } 12 \mathrm{~h} \\
\mathrm{de} \sim-0,1 \mathrm{a} \\
5,5\end{array}$ & $\begin{array}{l}11 \text { a } 13 \mathrm{~h} \\
\text { de } \sim-0,4 \text { a } \\
5,0\end{array}$ & $\begin{array}{l}8 \text { a } 10 \text { h } \\
\text { de } \sim-0,5 \text { a } 6,0\end{array}$ & $\begin{array}{l}9 \text { a } 13 \mathrm{~h} \\
\text { de 1,0 a } \\
4,5\end{array}$ \\
\hline $\begin{array}{l}\text { Horário em que, em alguns dias, a } \\
\text { fotossíntese começa a ter valores } \\
\text { negativos significativos; e faixa de } \\
\text { variação em } \mu \mathrm{mol} \mathrm{CO}_{2} \cdot \mathrm{m}^{-2} \cdot \mathrm{s}^{-1}\end{array}$ & $\begin{array}{lll}14 & \text { horas } & \\
\text { de } & -1,5 \quad \text { a } \\
1,5 & & \end{array}$ & $\begin{array}{lll}14 & \text { horas } & \\
\text { de } & -0,4 & \text { a } \\
1,5 & & \end{array}$ & $\begin{array}{l}14 \text { horas } \\
\text { de }-1,0 \text { a } 1,5\end{array}$ & 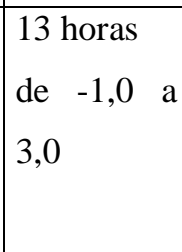 \\
\hline Horário a partir do qual respiram & 16 horas & 17 horas & 17 horas & 18 horas \\
\hline
\end{tabular}

*Em função do racionamento de energia e da restrição ao horário de ingresso no local do experimento.

Na Figura 5.1, também observa-se que os valores de fotossíntese são similares, nos três níveis das plântulas, no outono e inverno. Na primavera, os valores dos níveis 2 e 3 são semelhantes e maiores que do nível 1. No verão, os valores de fotossíntese do nível 3 são maiores que do nível 2, e do nível 2 maiores que do nível 1. Isto pode ser devido ao crescimento e à ramificação das plântulas, e por isso as folhas do nível 1 recebiam menos luz, além de que estavam senescentes.

Na Figura 5.2 são apresentados os gráficos do ciclo diário da condutância estomática. Nesses gráficos observa-se que os menores valores acontecem no começo e no final do dia e os maiores entre 10 e 15 horas, o que indica que as plântulas mantêm quase fechados os estômatos no começo e no fỉm do dia; e no transcurso do dia estes se abrem. No outono e no inverno, atingem os maiores valores, aproximadamente em torno de $0,15 \mathrm{~mol} \mathrm{H}_{2} \mathrm{O} \cdot \mathrm{m}^{-2} \cdot \mathrm{s}^{-1}$, na primavera em torno de $0,20 \mathrm{~mol} \mathrm{H} \mathrm{H}_{2} \mathrm{O} \cdot \mathrm{m}^{-2} \cdot \mathrm{s}^{-1}$, e no verão em torno de $0,13 \mathrm{~mol} \mathrm{H}_{2} \mathrm{O} \cdot \mathrm{m}^{-2} \cdot \mathrm{s}^{-1}$. 
Observa-se também que no outono e no inverno os valores de condutância são similares nos três níveis das plântulas. Na primavera e no verão os valores de condutância do nível 1 são menores que os dos níveis 2 e 3. Esta característica coincide com as medidas de fotossíntese, o que é válido já que a abertura dos estômatos está relacionada com a fotossíntese.
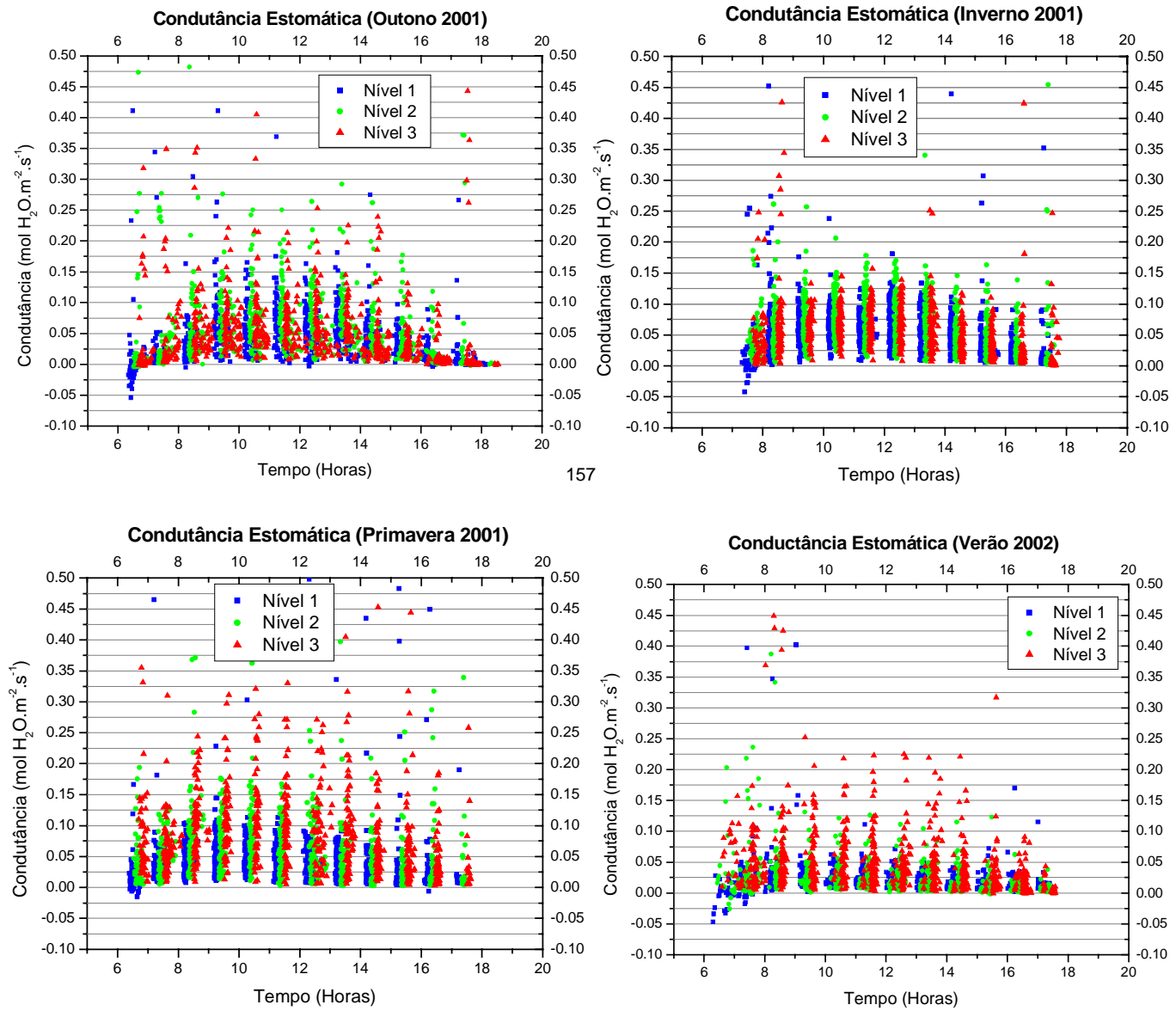

Figura 5.2 Medidas da condutância estomática das quatro estações.

Na Figura 5.3 são mostrados os gráficos do ciclo diário da taxa de transpiração. Ao começo do dia a transpiração é baixa, aumenta com o transcurso do dia e diminui no final do dia. No outono e no inverno atinge os maiores valores, entre 10 e 14 horas, aproximadamente em torno de 3,0 e de $3,5 \mu$ mol $\mathrm{H}_{2} \mathrm{O} \cdot \mathrm{m}^{-2} \cdot \mathrm{s}^{-1}$ respectivamente. Na primavera os maiores valores são entre 9 e 13 horas, em torno 
de aproximadamente $5 \mu \mathrm{mol} \mathrm{H}_{2} \mathrm{O} \cdot \mathrm{m}^{-2} \cdot \mathrm{s}^{-1}$. No verão os maiores valores atingidos são entre 9 e 14 horas, aproximadamente em torno de $2,75 \mu \mathrm{mol} \mathrm{H}_{2} \mathrm{O} \cdot \mathrm{m}^{-2} \cdot \mathrm{s}^{-1}$.

Outra característica observada, similar à fotossíntese e à condutância, é que no outono e no inverno os valores de transpiração são semelhantes nos três níveis das plântulas. Na primavera os valores nos níveis 2 e 3 são similares e maiores que os do nível 1. No verão os valores dos níveis 1 e 2 são semelhantes e menores que os do nível 3.
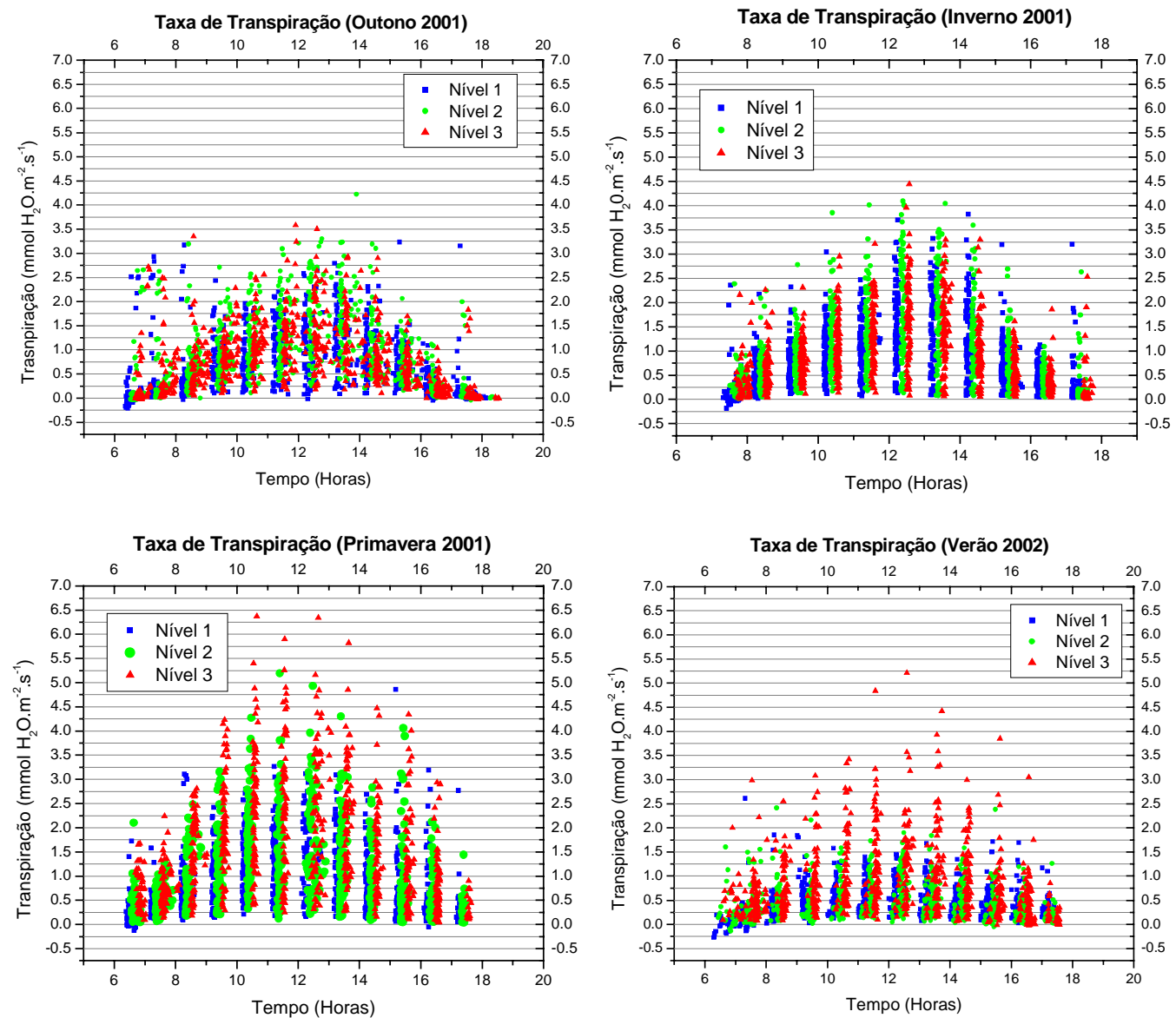

Figura 5.3 Medidas da taxa de transpiração das quatro estações.

Na Tabela 5.2 são mostrados os maiores valores atingidos pelas variáveis condutância estomática, taxa de transpiração e taxa de fotossíntese para mostrar a relação que existe entre estas variáveis. Nessa tabela observa-se uma 
correspondência direta entre a condutância estomática e a transpiração: à maior condutância corresponde maior transpiração, e à menor condutância, menor transpiração. Nessa tabela observa-se também uma correspondência direta entre a condutância estomática e a fotossíntese. Na primavera houve maior condutância estomática e conseqüentemente maior fotossíntese. É interessante notar que no verão as plântulas fecham os estômatos para evitar perda de líquido; isto implica menor transpiração, menor ingresso de $\mathrm{CO}_{2}$, e conseqüentemente menor fotossíntese, o que pode ser verificado observando a Tabela 5.2, última linha. Nessa linha nota-se que no verão houve os menores valores máximos de condutância, transpiração e fotossíntese. Estes resultados verificam tanto o controle da transpiração como a regulação de entrada de $\mathrm{CO}_{2}$ na folha através dos estômatos; e a influência das estações do ano (fatores ambientais) nessas variáveis fisiológicas.

Tabela 5.2 - Maiores valores atingidos de condutância estomática, taxa de transpiração e taxa de fotossíntese nas quatro estações do ano.

\begin{tabular}{|c|c|c|c|}
\hline Estação & $\begin{array}{c}\text { Condutância estomática } \\
\text { mol } \mathrm{H}_{2} \mathrm{O} \cdot \mathrm{m}^{-2} \cdot \mathrm{s}^{-1}\end{array}$ & $\begin{array}{c}\text { Taxa de transpiração } \\
\mu \mathrm{mol} \mathrm{H}_{2} \mathrm{O} \cdot \mathrm{m}^{-2} \cdot \mathrm{s}^{-1}\end{array}$ & $\begin{array}{c}\text { Taxa de fotossíntese } \\
\mu \mathrm{mol} \mathrm{C}_{2} \mathrm{O} \cdot \mathrm{m}^{-2} \cdot \mathrm{s}^{-1}\end{array}$ \\
\hline Outono & $\sim 0,15$ & $\sim 3,0$ & 5,5 \\
\hline Inverno & $\sim 0,15$ & $\sim 3,5$ & 5,0 \\
\hline Primavera & $\sim 0,20$ & $\sim 5,0$ & 6,0 \\
\hline Verão & $\sim 0,13$ & $\sim 2,75$ & 4,5 \\
\hline
\end{tabular}

Na Figura 5.4 são mostrados os gráficos do ciclo diário da fluorescência, razão entre as fluorescências variável e máxima (Fv/Fm), do outono, do inverno e da primavera. A razão Fv/Fm indica a eficiência fotossintética; quando o valor é igual ou maior que 0,7 é considerado um valor normal, mas quando é menor indica fotoinibição. Nos gráficos se observa que os valores medidos são maiores que 0,7 nos três níveis. No outono a eficiência fotossintética vária de 0,7 a 0,825 ; existem alguns pontos abaixo de 0,7 , mas são poucos. No inverno a eficiência varia de 0,72 a 0,83 e na primavera varia de 0,75 a 0,83 . As medidas de verão não foram realizadas por razões técnicas, explicadas no item 4.1.6. 

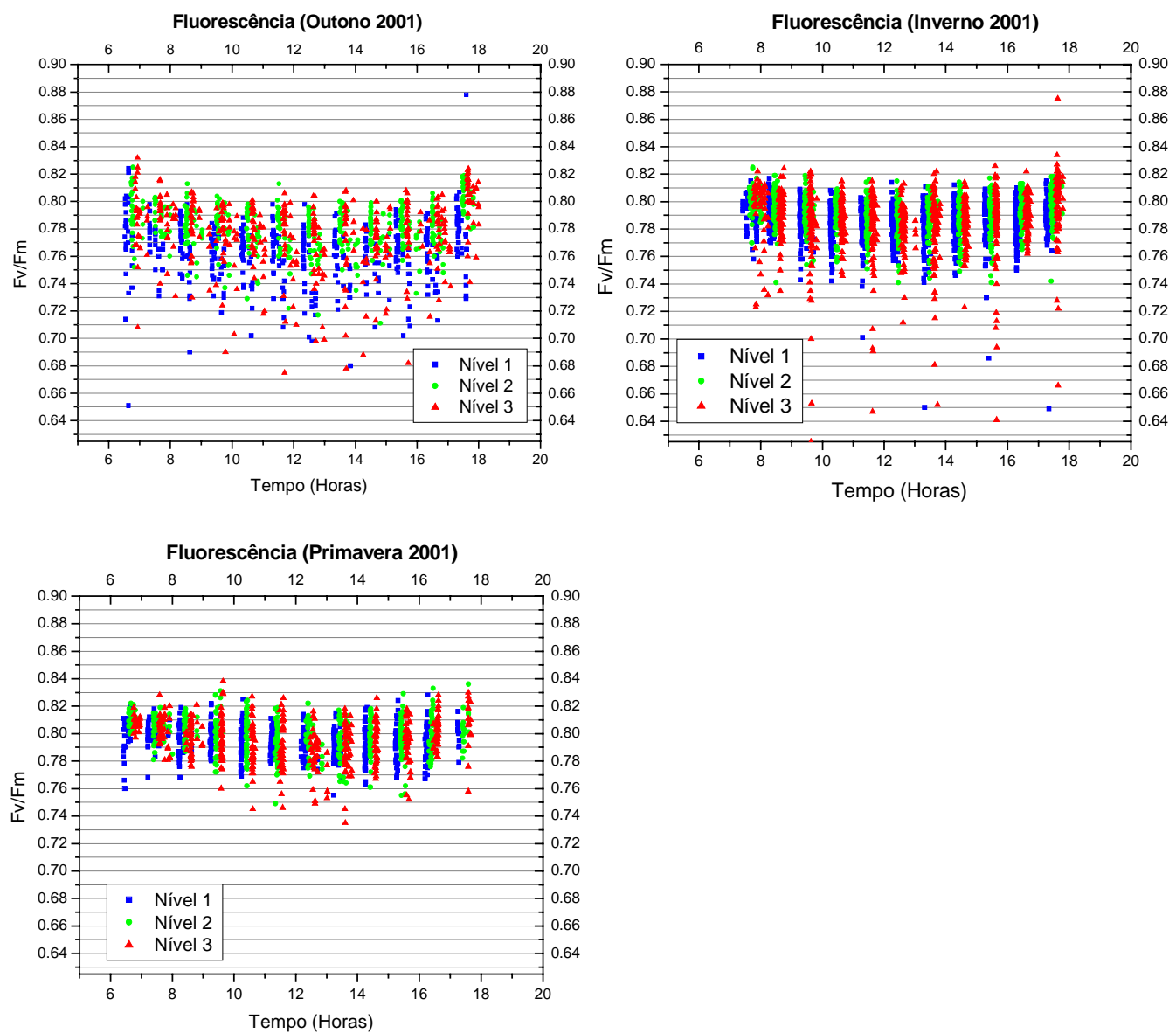

Figura 5.4 Medidas de fluorescência de três estações.

Nos gráficos da Figura 5.4 observa-se, também, que o comportamento da fluorescência é contrário ao da fotossíntese líquida, condutância estomática e taxa de transpiração. No começo do dia é maior, atinge valores mínimos entre 10 e 14 horas aproximadamente, e depois aumenta novamente. Isto devido a que quanto maior a disponibilidade de luz maior é a saturação dos fotossistemas, por isso a relação Fv/Fm tende a ser menor. Isto é, a relação Fv/Fm determina quanta capacidade de absorção de fótons de luz tem a folha; com o aumento de luz ao meio dia os fotossistemas tendem a saturar pelo que a fluorescência é reduzida.

Na Figura 5.5 são apresentados os gráficos do ciclo diário da temperatura da folha, e na Tabela 5.3 são indicadas as características principais das medidas dessa 
variável. Tanto na Figura 5.5 como na Tabela 5.3 observa-se que a temperatura é menor no começo do dia; atinge valores máximos, no outono e no inverno, entre 12 e 14 horas, na primavera, entre 12 e 16 horas, e no verão, entre 12 e 13 horas; e depois começa a diminuir.

Outra característica observada é que a temperatura da folha acompanha, como era de se esperar, as características da temperatura que ocorrem nas estações do ano. Os menores valores de temperatura ocorreram no inverno, e os maiores na primavera e no verão.
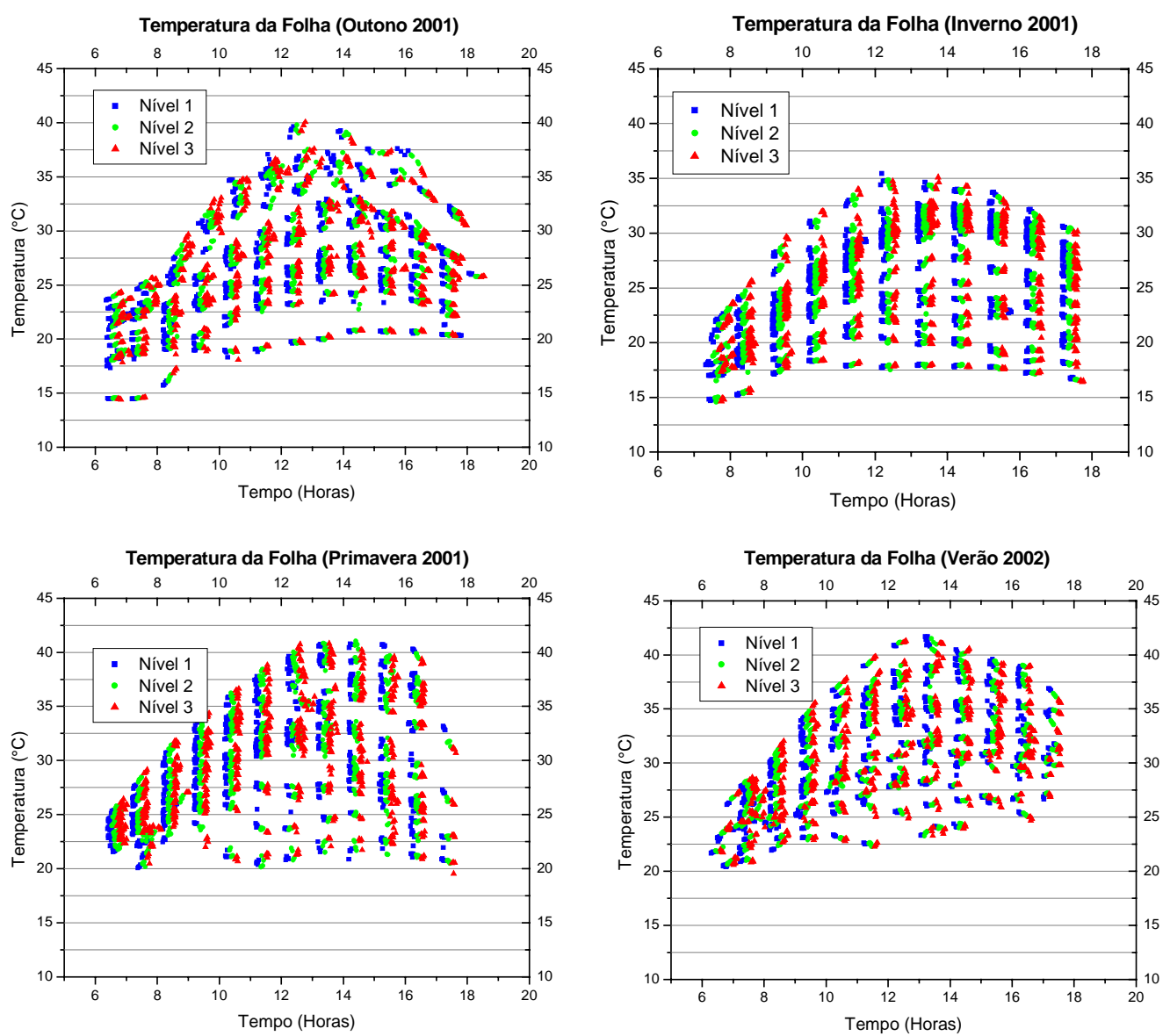

Figura 5.5 Medidas da temperatura da folha das quatro estações. 
Tabela 5.3 - Características das medidas da temperatura da folha, das quatro estações do ano.

\begin{tabular}{|l|c|c|l|c|}
\hline Características da temperatura & Outono & \multicolumn{1}{|c|}{ Inverno } & Primavera & Verão \\
\hline Temperatura às 6 horas $\left({ }^{\circ} \mathrm{C}\right)$ & 14,5 a 24 & $\begin{array}{c}\text { Não } \\
\text { disponível* }\end{array}$ & 23 a 26,5 & 20,5 a 27,5 \\
\hline Temperatura às 7 horas $\left({ }^{\circ} \mathrm{C}\right)$ & 14,5 a 26 & 14,5 a 28,5 & 20 a 29 & 21 a 28,5 \\
\hline $\begin{array}{l}\text { Horário em que atinge os maiores } \\
\text { valores e faixa de variação }\left({ }^{\circ} \mathrm{C}\right)\end{array}$ & 12 a $14 \mathrm{~h}$ & 12 a $14 \mathrm{~h}$ & 12 a $16 \mathrm{~h}$ & 12 a $13 \mathrm{~h}$ \\
23 a 41,5
\end{tabular}

*Em função do racionamento de energia e da restrição ao horário de ingresso no local do experimento.

\subsubsection{Resultados e análise das variáveis ambientais}

Como foi indicado item 4.1 , as variáveis ambientais medidas foram temperatura do ar, concentração de $\mathrm{CO}_{2}$ no ar, umidade relativa do ar, radiação fotossintética ativa dentro da câmara da folha (PARi), concentração de $\mathrm{CO}_{2}$ na câmara da folha, umidade relativa na câmara da folha, e radiação fotossintética ativa fora da câmara da folha (PARo). Os resultados das medidas dessas variáveis são apresentados nas figuras seguintes, desde a Figura 5.6 até a Figura 5.12, respectivamente. Em cada uma dessas figuras são mostrados gráficos da variável ambiental em função do tempo, das quatro estações do ano, e dos três níveis das plântulas.

Na Figura 5.6 são mostrados os gráficos do ciclo diário da temperatura do ar. Como era de se esperar, a temperatura é menor ao começar o dia, aumenta à medida que passam as horas, atinge um máximo e depois diminui.

Na Tabela 5.4 são apresentadas as características mais relevantes dessas medidas. Nessa tabela se observa que as menores temperaturas se dão no inverno e as maiores na primavera e no verão. 

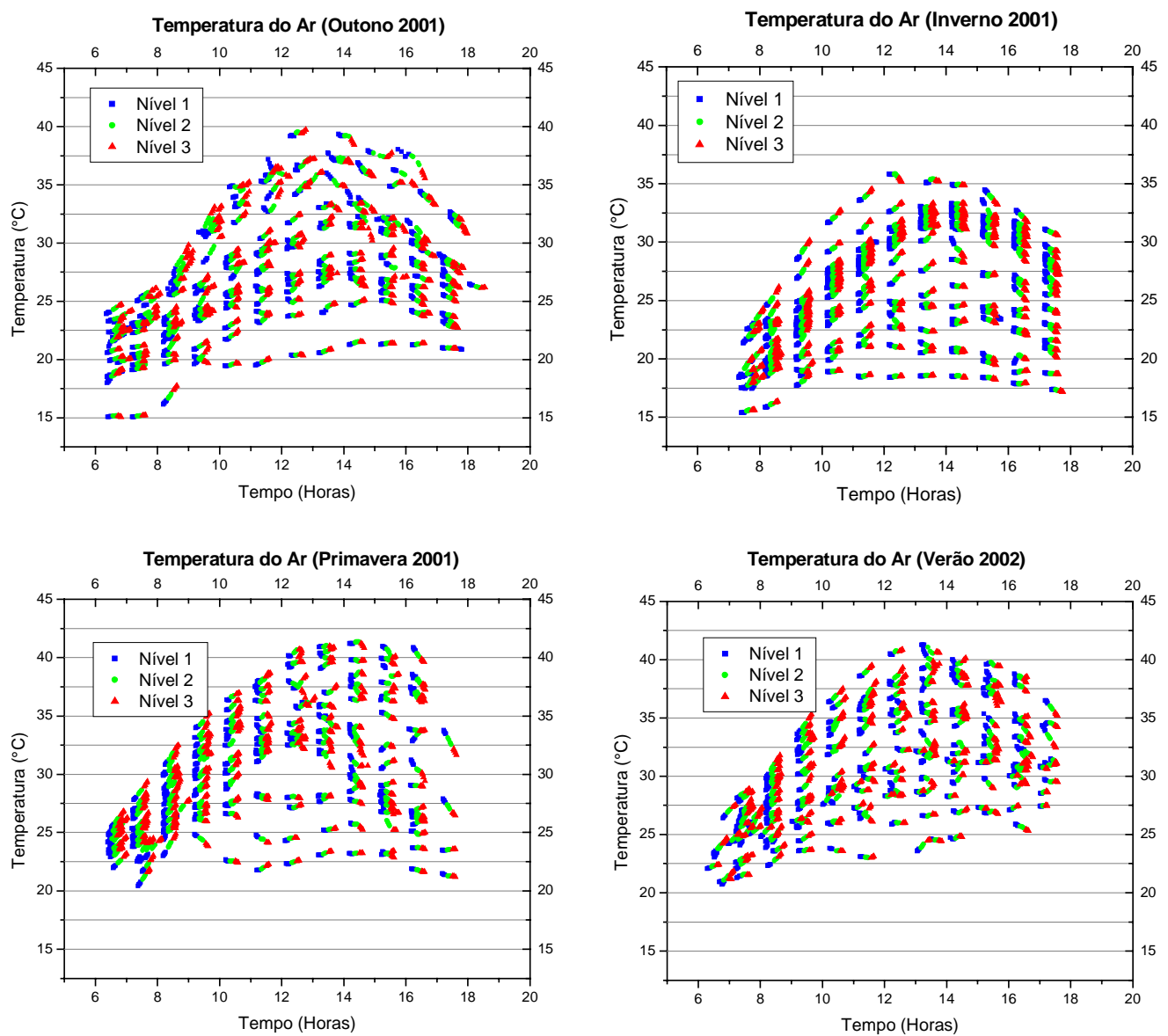

Figura 5.6 Medidas da temperatura do ar das quatro estações.

Tabela 5.4 - Características da temperatura do ar, medidas na câmara da folha, das quatro estações do ano.

\begin{tabular}{|l|l|l|l|l|}
\hline Características da temperatura & \multicolumn{1}{|c|}{ Outono } & \multicolumn{1}{|c|}{ Inverno } & Primavera & Verão \\
\hline Temperatura às 6 horas $\left({ }^{\circ} \mathrm{C}\right)$ & 15 a 25 & $\begin{array}{c}\text { Não } \\
\text { disponível* }\end{array}$ & 22 a 26 & 21 a 25 \\
\hline Temperatura às 7 horas $\left({ }^{\circ} \mathrm{C}\right)$ & 15 a 26 & 16 a 24 & 20 a 29 & 21 a 29 \\
\hline $\begin{array}{l}\text { Horário em que atinge os maiores } \\
\text { valores e faixa de variação }\left({ }^{\circ} \mathrm{C}\right)\end{array}$ & $\begin{array}{l}12 \text { a } 14 \mathrm{~h} \\
20 \text { a } 40\end{array}$ & $\begin{array}{l}12 \text { a } 14 \mathrm{~h} \\
18 \text { a } 36\end{array}$ & $\begin{array}{l}12 \text { a } 16 \mathrm{~h} \\
22 \text { a } 42\end{array}$ & $\begin{array}{l}12 \text { a } 13 \mathrm{~h} \\
23 \text { a } 42\end{array}$ \\
\hline Temperatura às 17 horas $\left({ }^{\circ} \mathrm{C}\right)$ & 21 a 32 & 17 a 31 & 21 a 34 & 27 a 37 \\
\hline
\end{tabular}

*Em função do racionamento de energia e da restrição ao horário de ingresso no local do experimento. 
Na Figura 5.7 são apresentados os gráficos do ciclo diário da concentração de $\mathrm{CO}_{2}$ do ar. Nessa figura observa-se que no horário das 6 horas a concentração de $\mathrm{CO}_{2}$ é maior, o que era esperado porque as plantas respiram à noite. No transcurso do dia a concentração de $\mathrm{CO}_{2}$ diminui, porque as plantas realizam fotossíntese. À tarde aumenta a concentração já que as plantas começam a respirar.

Para ilustrar melhor as características dos resultados das medidas de concentração de $\mathrm{CO}_{2}$ do ar foi elaborada a Tabela 5.5, a partir dos dados coletados e da Figura 5.7. Nessa tabela pode-se observar as variações de $\mathrm{CO}_{2}$ do ar nas quatro estações. No outono se dão as maiores concentrações de $\mathrm{CO}_{2}$ no horário das 6 horas. Durante o dia quando as plantas realizam fotossíntese, as menores concentrações de $\mathrm{CO}_{2}$ são no verão.
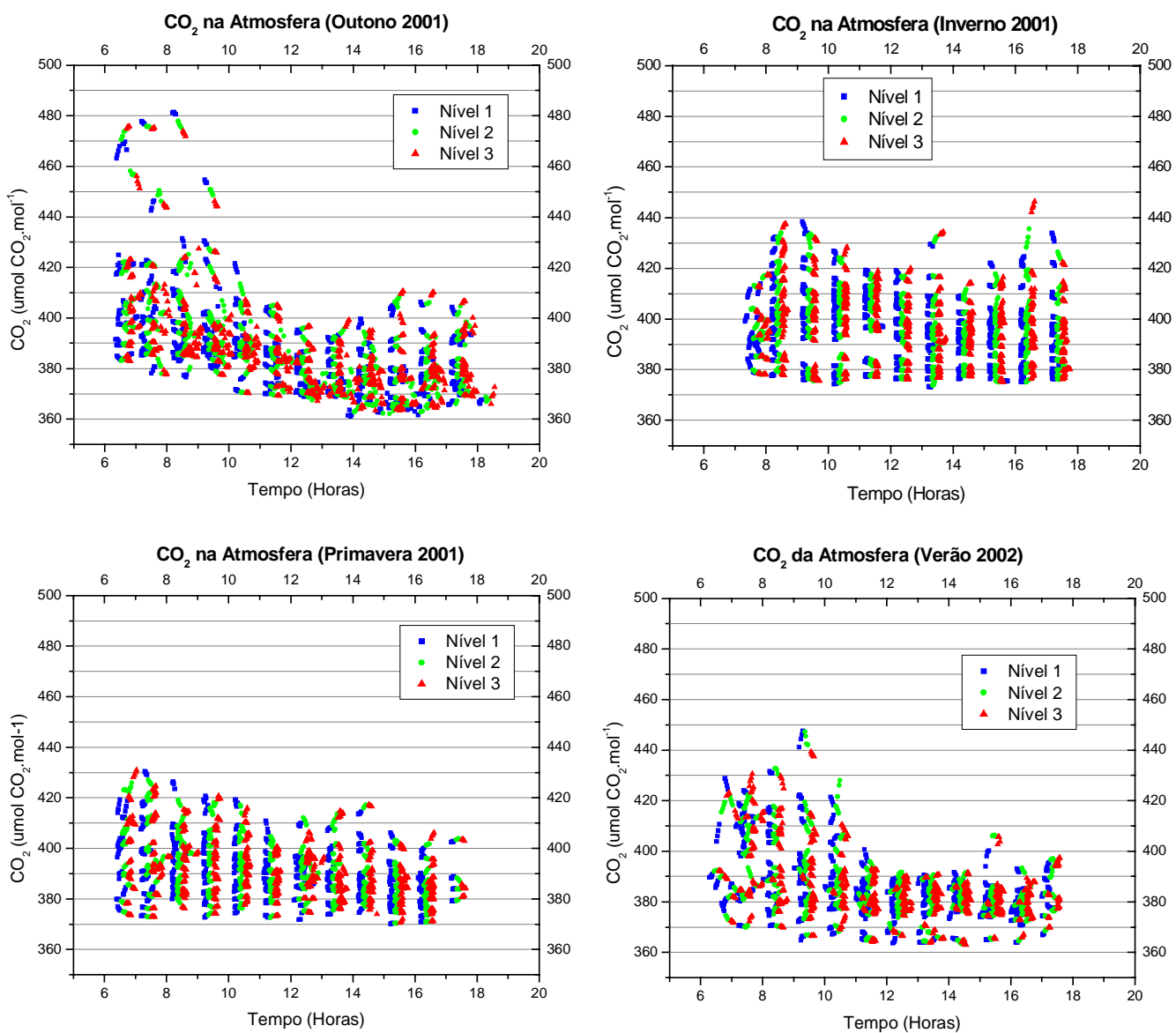

Figura 5.7 Medidas da concentração de $\mathrm{CO}_{2}$ do ar das quatro estações. 
Tabela 5.5 - Características das medidas de concentração de $\mathrm{CO}_{2}$ do ar.

\begin{tabular}{|c|c|c|c|c|}
\hline Características & Outono & Inverno & Primavera & Verão \\
\hline $\begin{array}{l}\mathrm{CO}_{2} \text { do ar às } 6 \text { horas } \\
\text { em } \mu \text { mol } \mathrm{CO}_{2} \cdot \mathrm{mol}^{-1}\end{array}$ & 385 a 478 & $\begin{array}{c}\text { Não } \\
\text { disponível* }\end{array}$ & 372 a 432 & 370 a 430 \\
\hline $\begin{array}{l}\mathrm{CO}_{2} \text { do ar às } 7 \text { horas } \\
\text { em } \mu \mathrm{mol} \mathrm{CO} 2 \cdot \mathrm{mol}^{-1}\end{array}$ & 378 a 478 & 378 a 416 & 373 a 431 & 370 a 431 \\
\hline $\begin{array}{l}\text { Horário em que atinge os menores } \\
\text { valores e faixa de variação } \\
\text { em } \mu \mathrm{mol} \mathrm{CO} 2 \cdot \mathrm{mol}^{-1}\end{array}$ & $\begin{array}{l}12 \text { a } 14 \text { h } \\
360 \text { a } 400\end{array}$ & $\begin{array}{l}11 \text { a } 15 \mathrm{~h} \\
375 \text { a } 420\end{array}$ & $\begin{array}{l}11 \text { a } 12 \text { h } \\
372 \text { a } 412\end{array}$ & $\begin{array}{l}12 \text { a } 14 \mathrm{~h} \\
364 \text { a } 392\end{array}$ \\
\hline $\begin{array}{l}\mathrm{CO}_{2} \text { do ar às } 17 \text { horas } \\
\mathrm{em} \mu \mathrm{mol} \mathrm{CO} 2 \cdot \mathrm{mol}^{-1}\end{array}$ & 368 a 408 & 375 a 435 & 378 a 405 & 365 a 398 \\
\hline
\end{tabular}

*Em função do racionamento de energia e da restrição ao horário de ingresso no local do experimento.

Na Figura 5.8 são apresentados os gráficos do ciclo diário da umidade relativa do ar. $\mathrm{O}$ comportamento desta variável é similar à concentração de $\mathrm{CO}_{2}$ do ar. A umidade é maior no início do dia, diminui no transcurso do dia e aumenta à tarde.

Na Tabela 5.6 são mostradas as características da umidade relativa do ar para as quatro estações. Nessa tabela observa-se que os maiores valores de umidade, no começo do dia, acontecem no outono, no inverno e no verão, e os menores valores na primavera. No final do dia, os menores valores de umidade sucedem no inverno e na primavera. Na primavera, no horário de 12 a 14 horas, houve a maior variação de umidade, de 16 a 75\%. Nesse horário observa-se que na primavera houve a menor e a maior umidade comparando com as outras estações. Vale a pena salientar que a umidade esteve influenciada, além das variações ambientais, pela rega das plantas na casa de vegetação. Talvez devido a isso observa-se nos gráficos da Figura 5.8 valores que saem do padrão das medidas. Por exemplo, no inverno observam-se dois agrupamentos de medidas no horário de 12 a 14 horas. 

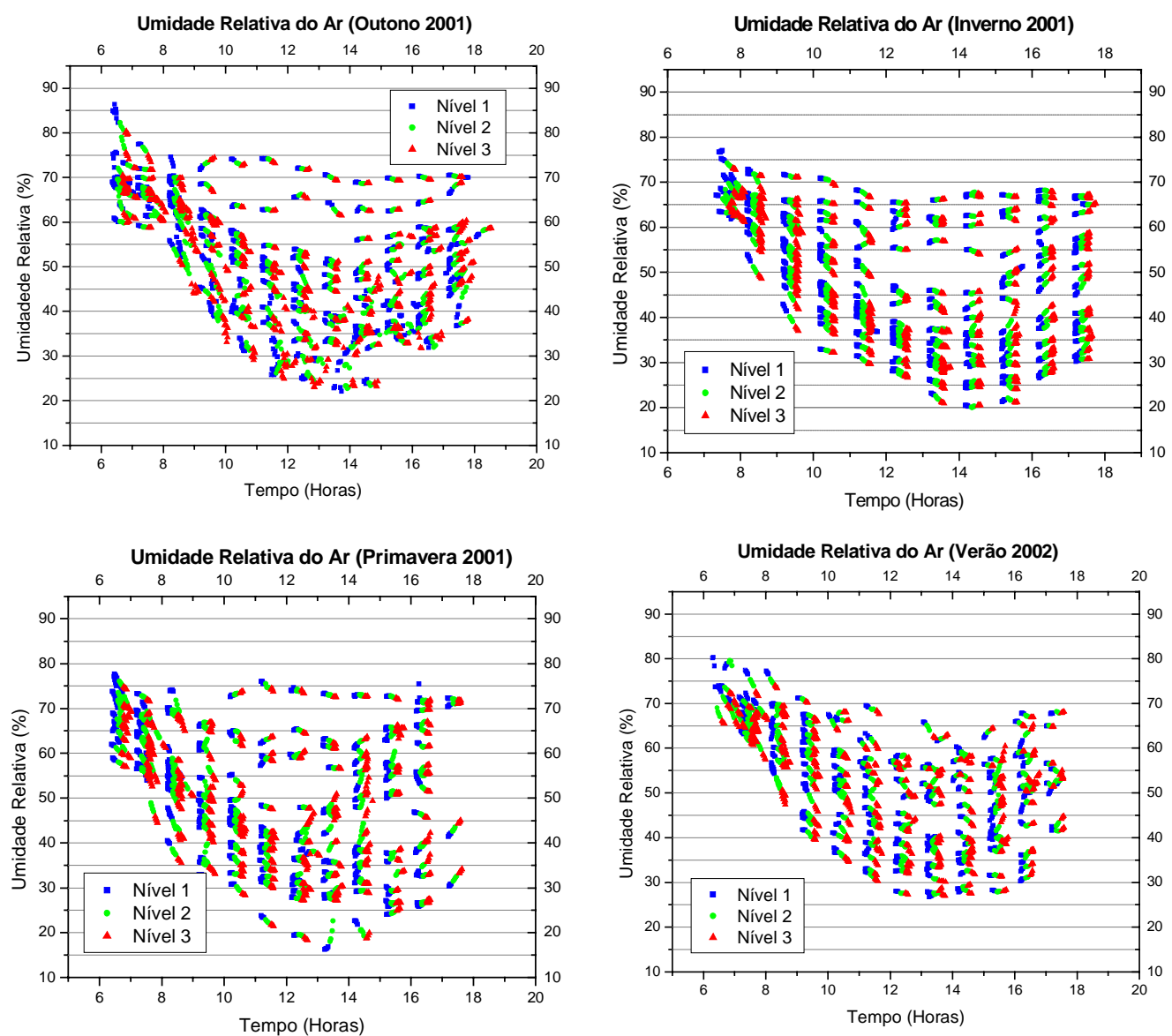

Figura 5.8 Medidas da umidade relativa do ar das quatro estações.

Tabela 5.6 - Características das medidas da umidade relativa do ar, das quatro estações do ano.

\begin{tabular}{|l|l|l|l|l|}
\hline \multicolumn{1}{|c|}{ Características da umidade do ar } & \multicolumn{1}{|c|}{ Outono } & \multicolumn{1}{|c|}{ Inverno } & Primavera & \multicolumn{1}{|c|}{ Verão } \\
\hline Umidade relativa às 6 horas em \% & 60 a 86 & $\begin{array}{c}\text { Não } \\
\text { disponível* }\end{array}$ & 56 a 78 & 65 a 81 \\
\hline Umidade relativa às 7 horas em \% & 59 a 77 & 62 a 77 & 52 a 74 & 61 a 78 \\
\hline $\begin{array}{l}\text { Horário em que atinge os menores valores } \\
\text { e faixa de variação em \% }\end{array}$ & $\begin{array}{l}11 \text { a } 14 \text { h } \\
22 \text { a } 75\end{array}$ & $\begin{array}{l}13 \text { a } 15 \text { h } \\
20 \text { a } 68\end{array}$ & $\begin{array}{l}12 \text { a } 14 \text { h } \\
16 \text { a } 75\end{array}$ & $\begin{array}{l}12 \text { a } 15 \text { h } \\
27 \text { a } 66\end{array}$ \\
\hline Umidade relativa do ar às 17 horas em \% & 37 a 71 & 30 a 68 & 30 a 73 & 42 a 68 \\
\hline
\end{tabular}

*Em função do racionamento de energia e da restrição ao horário de ingresso no local do experimento. 
Na Figura 5.9 são mostrados os gráficos do ciclo diário da radiação fotossintética ativa, medida dentro da câmara da folha, (PARi). Nessa figura, observa-se que os maiores valores de radiação acontecem no outono, mas por um período curto, duas horas, entre 11 e 12 horas, esses valores são poucos e foram medidos nos níveis 2 e 3 . Também se pode observar, no gráfico do outono, que para valores de radiação menores que $125 \mu$ mol, a radiação é mais ou menos similar nos três níveis. Acima desse valor, a maior radiação se dá no nível 3.
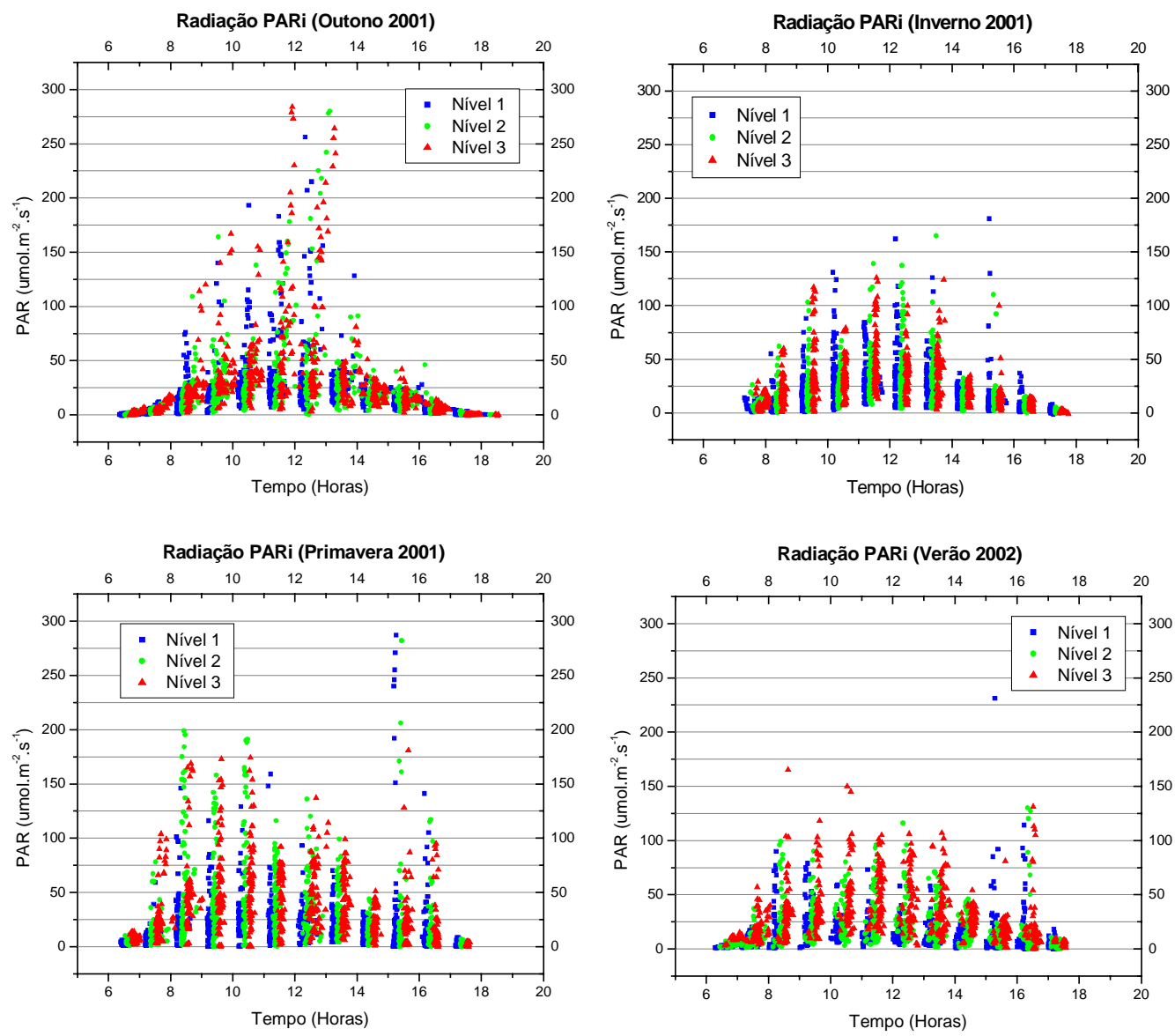

Figura 5.9 Medidas da radiação fotossintética ativa, dentro da câmara, (PARi) das quatro estações.

No inverno, o período de maior radiação é entre 9 e 13 horas. Às 14 horas observa-se uma queda, já explicada no item 5.1.1, e às 15 horas existem alguns picos, 
mas esses valores são poucos. Nesta estação, os valores de radiação são semelhantes nos três níveis.

$\mathrm{Na}$ primavera, os maiores valores de radiação são atingidos entre 8 e 10 horas. Como no inverno, às 14 horas existe uma queda, já explicada no item 5.1.1, e às 15 horas existem alguns picos que pertencem aos três níveis. Nesta estação, os valores de radiação dos níveis 2 e 3 são similares e maiores que os do nível 1.

No verão, os maiores valores de radiação são atingidos entre as 8 e 13 horas. Às 8 e às 9 horas a radiação é similar nos três níveis. Às 10 e as 13 horas a radiação no nível 3 é maior que no nível 2 e a radiação do nível 2 é maior que no nível 1. Às 7 , às 11 , às 12 e às 14 horas a radiação é similar nos níveis 2 e 3 e maior que a radiação no nível 1. Às 15 horas há uma queda abrupta e às 16 horas existem picos que pertencem aos 3 níveis.

Em geral, comparando a radiação que chega nos três níveis das plântulas nas quatro estações, pode-se dizer que no outono e no inverno os valores de radiação foram mais ou menos iguais, nos três níveis. Na primavera a radiação é aproximadamente igual nos níveis 2 e 3, e essa radiação é maior que no nível 1 . No verão a radiação é maior no nível 3; esta é maior que do nível 2, e a radiação do nível 2 é maior que do nível 1. Essas variações de radiação estão relacionadas com o crescimento das plântulas: no outono as plântulas não tinham ramificação e no inverno a ramificação era pouca. Portanto, a radiação chegava nos três níveis das plântulas sem muita interferência, como se pode observar nas medidas. Na primavera as plântulas já tinham mais ramificação que no inverno, por isso, observa-se nas medidas que há menor radiação no nível 1. No verão as plântulas se ramificaram bastante, tinham mais de um ano, pelo que a radiação que chega no nível 1 tem maior interferência, e no nível 2 também há sombra; por esta razão observa-se a variação de radiação nos três níveis.

A partir dos dados coletados e da Figura 5.9 foi elaborada a Tabela 5.7, para poder observar melhor o comportamento desta variável nas quatro estações. Nessa 
tabela, pode-se observar que no verão há maior período de radiação. No outono acontecem os maiores valores de radiação, mas por um período curto. Como era de esperar, na primavera e no verão há maior radiação às 6 horas e no outono ela é ínfima ou não há. No verão se dá a maior radiação às 17 horas e no outono a menor.

Tabela 5.7 - Características das medidas da radiação fotossintética ativa dentro da câmara da folha (PARi), das quatro estações do ano.

\begin{tabular}{|c|c|c|c|c|}
\hline Características da radiação & Outono & Inverno & Primavera & Verão \\
\hline PARi às 6 horas em $\mu$ mol. $\mathrm{m}^{-2} \cdot \mathrm{s}^{-1}$ & De 0 a 3 & $\begin{array}{c}\text { Não } \\
\text { disponível* }\end{array}$ & De 1 a 13 & De 1 a 12 \\
\hline PARi às 7 horas em $\mu$ mol. $\mathrm{m}^{-2} \cdot \mathrm{s}^{-1}$ & De 0 a 15 & De 0 a 30 & De 0 a 110 & De 0 a 60 \\
\hline $\begin{array}{l}\text { Horário em que atingem os } \\
\text { maiores valores e faixa de } \\
\text { variação em } \mu \text { mol. } \mathrm{m}^{-2} . \mathrm{s}^{-1}\end{array}$ & $\begin{array}{l}11 \text { a } 12 \mathrm{~h} \\
\text { de } \sim 0 \text { a } 275\end{array}$ & $\begin{array}{l}9 \text { a } 13 \mathrm{~h} \\
\text { de } \sim 0 \text { a } 125\end{array}$ & $\begin{array}{l}8 \text { a } 10 \text { h } \\
\text { de } \sim 0 \text { a } 175\end{array}$ & $\begin{array}{l}8 \text { a } 13 \mathrm{~h} \\
\text { de } \sim 0 \text { a } 110\end{array}$ \\
\hline $\begin{array}{l}\text { PARi às } 17 \text { horas } \\
\text { em } \mu \text { mol.m }{ }^{-2} \cdot s^{-1}\end{array}$ & De 0 a 3 & De 0 a 8 & De 0 a 7 & De 0 a 18 \\
\hline
\end{tabular}

*Em função do racionamento de energia e da restrição ao horário de ingresso no local do experimento.

Comparando as variáveis de fotossíntese (Figura 5.1) e radiação PARi (Figura 5.9), observa-se que as quedas de radiação no inverno e na primavera (14 horas), e no verão (15 horas), coincidem com as quedas de fotossíntese nesses horários. Também, pode-se observar que o período de maior radiação coincide com o período de maior fotossíntese, nas quatro estações do ano, especialmente no outono e na primavera, o que mostra a influência da radiação na fotossíntese.

Os resultados das medidas das variáveis concentração de $\mathrm{CO}_{2}$ na câmara da folha, umidade relativa na câmara da folha e radiação fotossintética ativa fora da câmara da folha (PARo), são mostrados na Figura 5.10, na Figura 5.11 e na Figura 5.12, respectivamente. O comportamento destas variáveis é similar ao comportamento das variáveis concentração de $\mathrm{CO}_{2}$ do ar, umidade relativa do ar e 
radiação fotossintética ativa dentro da câmara da folha (PARi), respectivamente. Mas existem diferenças entre elas. Essas diferenças serão tratadas a seguir.

Na Figura 5.10 são mostrados os gráficos do ciclo diário da concentração de $\mathrm{CO}_{2}$ na câmara da folha, e na Tabela 5.8 são mostradas as características desta variável nas quatro estações do ano.
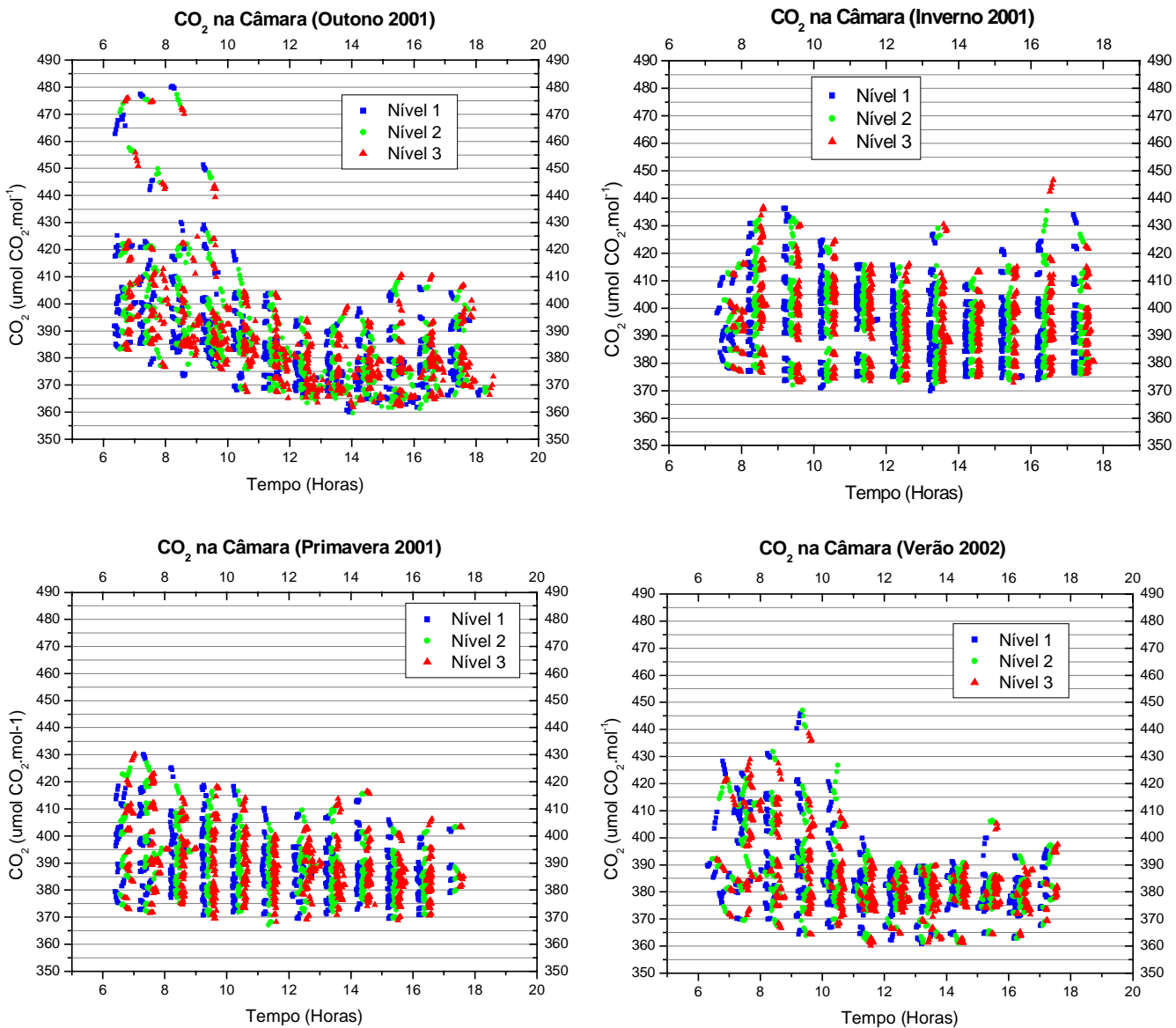

Figura 5.10 Medidas da concentração de $\mathrm{CO}_{2}$ na câmara da folha das quatro estações.

Observando as características das variáveis concentração de $\mathrm{CO}_{2}$, no ar e na câmara (Tabela 5.5 e Tabela 5.8), nota-se que, nos horários das 6 e das 17 horas, os valores de $\mathrm{CO}_{2}$ na câmara são ligeiramente maiores ou iguais que os valores de $\mathrm{CO}_{2}$ do ar. Isso é razoável, pois no horário das 6 horas as plântulas estão respirando ou 
estão no ponto de compensação, e no horário das 17 horas as plântulas começam a respirar. No horário das 7 horas os valores de $\mathrm{CO}_{2}$ do ar são ligeiramente maiores que os valores de $\mathrm{CO}_{2}$ na câmara, porque as plântulas começam com o processo de fotossíntese. Em geral de 7 a 16 horas os valores de $\mathrm{CO}_{2}$ do ar são maiores que os valores de $\mathrm{CO}_{2}$ na câmara em maior grau, devido às plântulas estarem realizando fotossíntese. Entretanto há valores de $\mathrm{CO}_{2}$ do ar que são menores que os valores de $\mathrm{CO}_{2}$ na câmara, devido à fotorrespiração das plântulas.

Tabela 5.8 - Características das medidas de concentração de $\mathrm{CO}_{2}$ na câmara da folha.

\begin{tabular}{|c|c|c|c|c|}
\hline Características & Outono & Inverno & Primavera & Verão \\
\hline $\begin{array}{l}\mathrm{CO}_{2} \text { na câmara da folha às } 6 \text { horas } \\
\mathrm{em} \mu \mathrm{mol} \mathrm{CO} \cdot \mathrm{mol}^{-1}\end{array}$ & 382 a 478 & $\begin{array}{c}\text { Não } \\
\text { disponível* }\end{array}$ & 373 a 431 & 370 a 430 \\
\hline $\begin{array}{l}\mathrm{CO}_{2} \text { na câmara da folha às } 7 \text { horas } \\
\text { em } \mu \mathrm{mol} \mathrm{CO} \cdot \mathrm{mol}^{-1}\end{array}$ & 376 a 479 & 376 a 416 & 371 a 431 & 370 a 430 \\
\hline $\begin{array}{l}\text { Horário em que atinge os menores } \\
\text { valores e faixa de variação em } \\
\mu \mathrm{mol} \mathrm{CO} \cdot \mathrm{mol}^{-1}\end{array}$ & $\begin{array}{l}12 \text { a } 14 \text { h } \\
360 \text { a } 400\end{array}$ & $\begin{array}{l}11 \text { a } 15 \text { h } \\
375 \text { a } 416\end{array}$ & $\begin{array}{l}11 \text { a } 12 \mathrm{~h} \\
376 \text { a } 410\end{array}$ & $\begin{array}{l}12 \text { a } 14 \mathrm{~h} \\
360 \text { a } 392\end{array}$ \\
\hline $\begin{array}{l}\mathrm{CO}_{2} \text { na câmara da folha às } 17 \text { horas } \\
\text { em } \mu \mathrm{mol} \mathrm{CO} \cdot \mathrm{mol}^{-1}\end{array}$ & 368 a 409 & 376 a 436 & 379 a 409 & 368 a 398 \\
\hline
\end{tabular}

*Em função do racionamento de energia e da restrição ao horário de ingresso no local do experimento.

Na Figura 5.11 são mostrados os gráficos do ciclo diário da umidade relativa na câmara da folha, e na Tabela 5.9 são apresentadas as características desta variável nas quatro estações do ano.

Observando as características das variáveis umidade relativa, no ar e na câmara, ver Tabela 5.6 e Tabela 5.9, em geral nota-se que os valores de umidade relativa na câmara são maiores ou iguais aos valores de umidade relativa do ar; isto pode ser devido à transpiração das plântulas. 

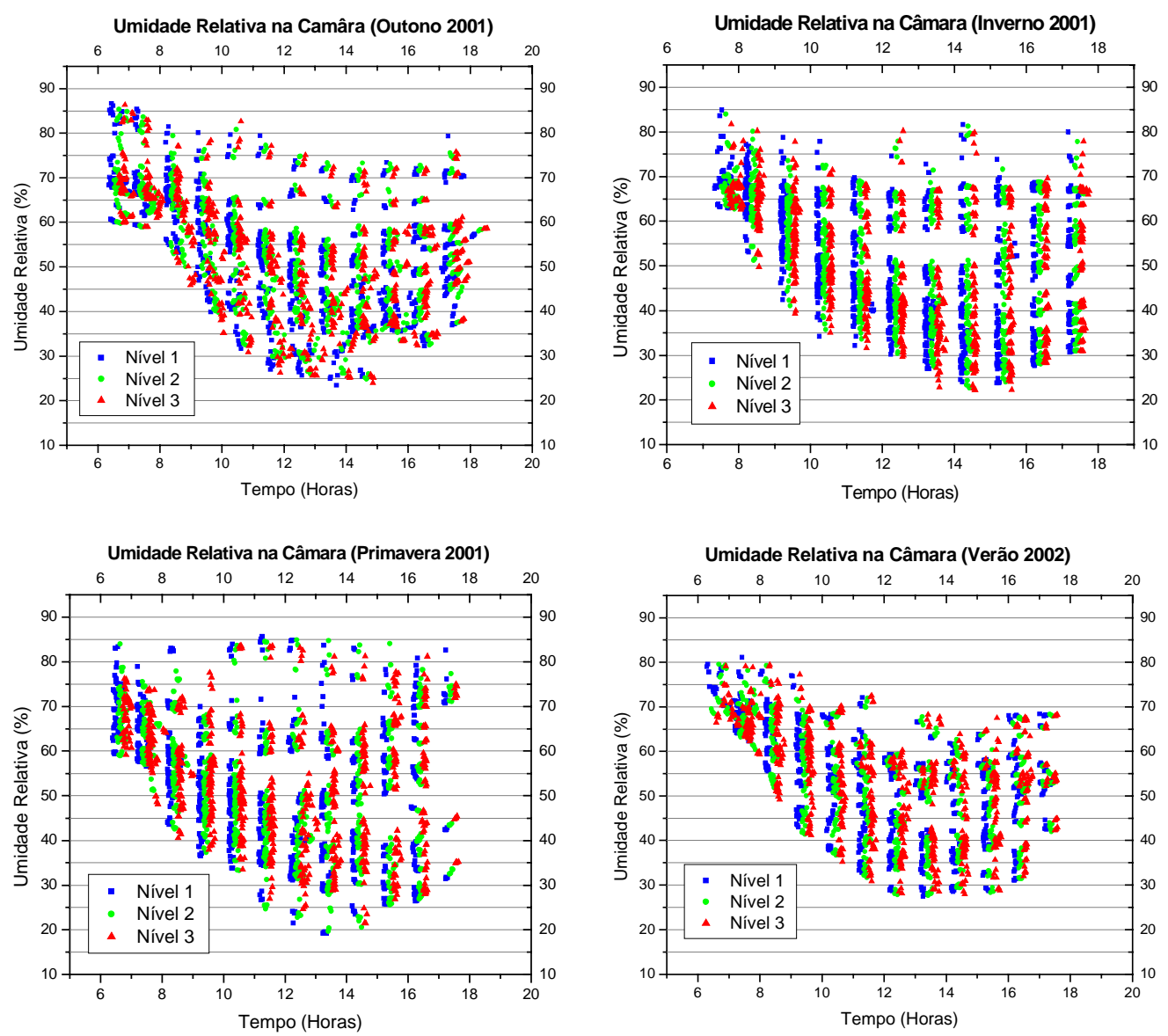

Figura 5.11 Medidas da umidade relativa na câmara da folha das quatro estações. 
Tabela 5.9 - Características das medidas da umidade relativa na câmara da folha, das quatro estações do ano.

\begin{tabular}{|l|l|l|l|l|}
\hline \multicolumn{1}{|c|}{ Características da umidade } & \multicolumn{1}{|c|}{ Outono } & \multicolumn{1}{c|}{ Inverno } & Primavera & \multicolumn{1}{c|}{ Verão } \\
\hline $\begin{array}{l}\text { Umidade relativa na câmara da folha } \\
\text { às } 6 \text { horas em \% }\end{array}$ & $\begin{array}{c}\text { Não } \\
\text { disponível* }\end{array}$ & 59 a 85 & 66 a 80 \\
\hline $\begin{array}{l}\text { Umidade relativa na câmara da folha } \\
\text { às } 7 \text { horas em \% }\end{array}$ & 59 a 86 & 63 a 85 & 48 a 79 & 60 a 80 \\
\hline $\begin{array}{l}\text { Horário em que atinge os menores } \\
\text { valores e faixa de variação em \% }\end{array}$ & $\begin{array}{l}11 \text { a } 14 \mathrm{~h} \\
24 \text { a } 80\end{array}$ & $\begin{array}{l}13 \text { a } 15 \mathrm{~h} \\
22 \text { a } 82\end{array}$ & $\begin{array}{l}12 \text { a } 14 \mathrm{~h} \\
20 \text { a } 85\end{array}$ & $\begin{array}{l}12 \text { a } 15 \mathrm{~h} \\
27 \text { a } 78\end{array}$ \\
\hline $\begin{array}{l}\text { Umidade relativa na câmara da folha } \\
\text { às } 17 \text { horas em \% }\end{array}$ & 370 & 30 a 81 & 31 a 83 & 42 a 69 \\
\hline
\end{tabular}

*Em função do racionamento de energia e da restrição ao horário de ingresso no local do experimento.

Na Figura 5.12 são mostrados os gráficos do ciclo diário da radiação fotossintética ativa fora da câmara da folha, e na Tabela 5.10 são mostradas as características desta variável nas quatro estações do ano.

Tabela 5.10 - Características das medidas da radiação fotossintética ativa fora da câmara da folha (PARo), das quatro estações do ano.

\begin{tabular}{|c|c|c|c|c|}
\hline Características da radiação & Outono & Inverno & Primavera & Verão \\
\hline PARo às 6 horas em $\mu$ mol.m. ${ }^{-2} \cdot \mathrm{s}^{-1}$ & De 0 a 6 & $\begin{array}{c}\text { Não } \\
\text { disponível* }\end{array}$ & De 2 a 17 & De 2 a 17 \\
\hline PARo às 7 horas em $\mu$ mol.m. $\mathrm{m}^{-2} \cdot \mathrm{s}^{-1}$ & De 2 a 24 & De 1 a 37 & De 1 a 106 & De 3 a 60 \\
\hline $\begin{array}{l}\text { Horário em que atingem os } \\
\text { maiores valores e faixa de } \\
\text { variação em } \mu \text { mol. } \mathrm{m}^{-2} . \mathrm{s}^{-1}\end{array}$ & $\begin{array}{l}11 \text { a } 12 \mathrm{~h} \\
\text { de } \sim 0 \text { a } 375\end{array}$ & $\begin{array}{l}10 \text { a } 13 \mathrm{~h} \\
\text { de } \sim 5 \text { a } 200\end{array}$ & $\begin{array}{l}8 \text { a } 10 \text { h } \\
\text { de } \sim 0 \text { a } 175\end{array}$ & $\begin{array}{l}8 \text { a } 13 \text { h } \\
\text { de } \sim 1 \text { a } 140\end{array}$ \\
\hline $\begin{array}{l}\text { PARo às } 17 \text { horas } \\
\text { em } \mu \text { mol. } \mathrm{m}^{-2} . \mathrm{s}^{-1}\end{array}$ & De 0 a 9 & De 0 a 14 & De 0 a 41 & De 1 a 45 \\
\hline
\end{tabular}

*Em função do racionamento de energia e da restrição ao horário de ingresso no local do experimento. 

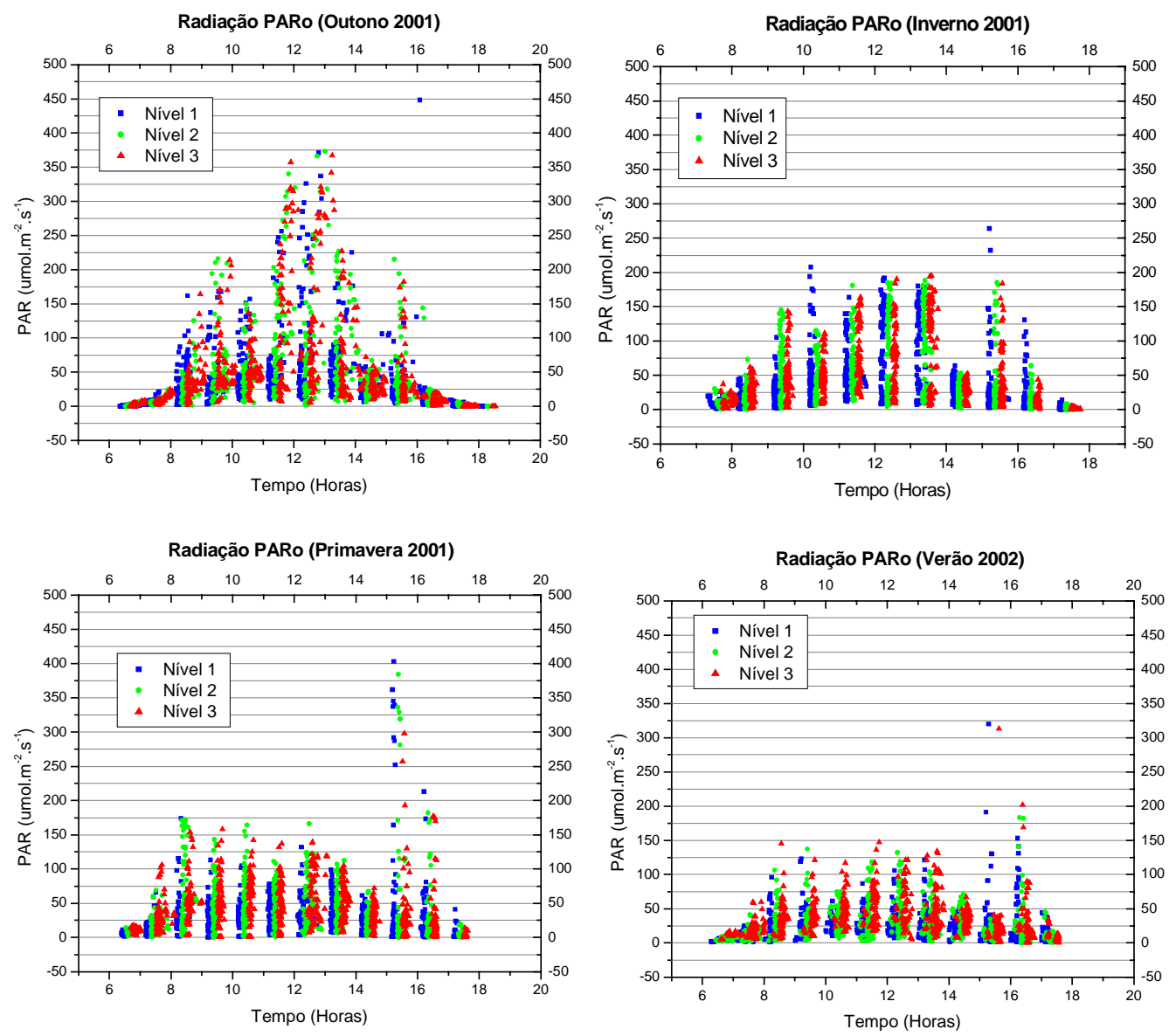

Figura 5.12 Medidas da radiação fotossintética ativa, fora da câmara, (PARo) das quatro estações.

Comparando as características apresentadas pelas variáveis radiação fotossintética ativa dentro e fora da câmara da folha (Tabela 5.7 e Tabela 5.10), notase que os valores de radiação fotossintética ativa fora da câmara da folha são maiores que os valores medidos dentro da câmara. Isto é compreensível, porque o sensor que está dentro da câmara da folha recebe menor radiação.

Observando os resultados apresentados nos diversos gráficos, tanto das variáveis fisiológicas como das variáveis ambientais, nota-se uma dispersão dos valores em um mesmo horário nos vários dias da estação. Isto pode ser atribuído às variações do clima, como dias nublados, dias com sol e dias com chuva, e à evolução 
dos dias na estação. No caso das variáveis fisiológicas, além das mudanças do clima, a dispersão deve-se também às condições intrínsecas das plântulas.

\subsubsection{Considerações finais}

A análise dos resultados da fitomonitoração mostrou características importantes sobre o comportamento das variáveis fisiológicas fotossíntese, condutância estomática, transpiração, fluorescência e temperatura da folha, em plântulas de jatobá, nas quatro estações do ano. A análise, também, mostrou características sobre o comportamento das variáveis ambientais temperatura do ar, concentração de $\mathrm{CO}_{2}$, umidade relativa e radiação fotossintética ativa.

A análise dos resultados das medidas de fotossíntese indica que este processo começa mais tarde, no outono e no inverno, e mais cedo, na primavera e no verão. Os valores máximos acontecem entre 11 e 12 horas, no outono e no inverno, e entre 9 e 10 horas, na primavera e no verão. Os maiores valores de fotossíntese foram atingidos na primavera. Os valores de fotossíntese são similares nos três níveis (partes inferior, média e superior da plântula), no outono e no inverno. Na primavera e no verão, os valores de fotossíntese do nível inferior são menores, devido ao crescimento e ramificação das plântulas; conseqüentemente as folhas do nível inferior recebiam menor radiação, além de que as folhas estavam senescentes em comparação com as folhas do nível superior.

Os resultados das medidas da condutância estomática e da taxa de transpiração mostram que os maiores valores foram atingidos na primavera, e os menores valores no verão. Os resultados mostram também que há uma correspondência direta entre essas variáveis; menor a condutância, menor a transpiração, e maior a condutância, maior a transpiração.

Ao comparar os resultados das medidas condutância estomática e fotossíntese, observou-se uma relação direta; maior a condutância estomática, maior 
a fotossíntese, mostrando assim a regulação do ingresso de $\mathrm{CO}_{2}$ na folha através dos estômatos.

Os resultados das medidas de fluorescência indicam que as plântulas estiveram em condições normais, ou seja, as plântulas não apresentaram fotoinibição.

Os resultados das medidas da temperatura da folha mostram que esta variável acompanha o comportamento da temperatura do ambiente. Os maiores valores de temperatura da folha e do ar aconteceram na primavera e no verão, e os menores no inverno, como era de se esperar.

Os resultados das medidas de concentração de $\mathrm{CO}_{2}$, no ar e na câmara da folha, mostram que essas variáveis têm um comportamento similar. Mas também, existem diferenças: nos horários das 6 e das 17 horas, a concentração de $\mathrm{CO}_{2}$ na câmara é maior ou igual à concentração no ar. Das 7 às 16 horas, em geral, a concentração de $\mathrm{CO}_{2}$ na câmara é menor que a concentração do ar.

Os resultados das medidas de umidade relativa, no ar e na câmara, apresentam um comportamento similar. Mas a umidade relativa na câmara é maior que a umidade no ar.

Os resultados das medidas de radiação fotossintética ativa, dentro e fora da câmara da folha, apresentaram um comportamento similar. Mas, como era de se esperar, a radiação fora da câmara da folha foi maior que a radiação dentro da câmara.

Ao comparar os resultados da radiação fotossintética ativa dentro da câmara e a fotossíntese, observa-se que existe uma relação direta entre elas, o que mostra a influência da radiação PAR na fotossíntese. 


\subsection{Resultados e discussão da modelagem com redes neurais artificiais}

Neste item serão apresentados e discutidos os resultados da modelagem do ciclo diário de fotossíntese, obtidos com o método explicado no item 4.2.

Como a análise dos resultados das medidas de fotossíntese mostrou que o comportamento da fotossíntese varia entre as estações (item 5.1.1), a modelagem foi dividida em duas fases, para observar se as estações influem na modelagem:

a) Primeira fase: modelagem do ciclo diário de fotossíntese por estação.

b) Segunda fase: modelagem do ciclo diário de fotossíntese por ano.

Na primeira fase, modelagem do ciclo diário de fotossíntese por estação, redes neurais foram treinadas com dados separados por estação: outono, inverno, primavera e verão. Na segunda fase, modelagem do ciclo diário de fotossíntese por ano, redes neurais foram treinadas com os dados das quatro estações.

Tanto na primeira como na segunda fase, a modelagem foi realizada para cada um dos três níveis onde foram coletados os dados: nível 1, medidas realizadas na parte inferior da plântula; nível 2, medidas realizadas na metade da plântula; e nível 3, medidas realizadas na parte superior da plântula, como foi mencionado no item 4.1.4. Portanto, foram obtidos modelos para as folhas dos três níveis. 


\subsubsection{Primeira fase: modelagem do ciclo diário de fotossíntese por estação}

\subsubsection{Considerações iniciais}

Nesta primeira fase da modelagem do ciclo diário de fotossíntese, os treinamentos das redes neurais foram realizados com os dados separados por estações.

A proposta inicial previa a modelagem de fotossíntese, no nível da folha, com redes neurais artificiais, em função das seguintes variáveis: concentração de $\mathrm{CO}_{2}$ do ar, umidade relativa do ar, radiação fotossintética ativa, medida dentro da câmara da folha (PARi), temperatura do ar, temperatura da folha e instante da medida (tempo). Desejava-se modelar fotossíntese com as variáveis ambientais medidas no ar, fora da câmara; exceto PARi, que é a radiação que chega justo na folha que está sendo medida.

Desejava-se avaliar, também, quais eram as variáveis de entrada, mostradas na Tabela 4.8, que influíam mais na modelagem de fotossíntese. Portanto, foram definidas diferentes combinações de entrada. Na Tabela 5.11 são mostradas essas combinações, com o correspondente número de identificação.

Definidas as diferentes combinações de variáveis de entrada, foram realizados treinamentos, com os dados de outono, para as folhas do nível 1. O quadro dos casos treinados é apresentado na Tabela 5.12, onde são mostrados a estrutura da rede e os parâmetros de treinamento. Na camada de entrada foram utilizados $6,7,8,9$, ou 10 neurônios, conforme as combinações mostradas na Tabela 5.11. $\mathrm{Na}(\mathrm{s})$ camada(s) escondida(s), observa-se a letra $X$ a partir do caso 11 , sendo $X$ o número de neurônios que dependia dos resultados obtidos nos casos 1 a 10. Desses dez primeiros casos selecionava-se um, o que apresentava melhor resultado. A estrutura desse caso era usada para realizar os treinamentos dos 11 casos restantes, onde o que 
se variava, sobretudo, eram os coeficientes de aprendizado, além de tolerância e iterações internas.

Tabela 5.11 - Combinações de variáveis de entrada utilizadas no treinamento.

\begin{tabular}{|c|c|}
\hline Combinação & Variáveis de entrada (VE) \\
\hline 1 & $6 \mathrm{VE}$ : Tempo, Tar, Tfol, $\mathrm{CO}_{2}$ ar, Umiar, PARi \\
\hline 2 & 6 VE: Tempo, Tar, Tfol, $\mathrm{CO}_{2}$ câ, Umiar, PARi \\
\hline 3 & 6 VE: Tempo, Tar, Tfol, $\mathrm{CO}_{2}$ câ, Umiar, PARo \\
\hline 4 & 6 VE: Tempo, Tar, Tfol, $\mathrm{CO}_{2}$ câ, Umicâ, PARi \\
\hline 5 & 7 VE: Tempo, Planta, Tar, Tfol, $\mathrm{CO}_{2}$ ar, Umiar, PARi \\
\hline 6 & 7 VE: Tempo, Tar, Tfol, $\mathrm{CO}_{2}$ ar, $\mathrm{CO}_{2}$ câ, Umiar, PARi \\
\hline 7 & 8 VE: Tempo, Planta, Tar, Tfol, $\mathrm{CO}_{2}$ ar, $\mathrm{CO}_{2}$ câ, Umiar, PARi \\
\hline 8 & 8 VE: Tempo, Tar, Tfol, $\mathrm{CO}_{2}$ câ, Umiar, Umicâ, PARi, PARo \\
\hline 9 & 8 VE: Tempo, Tar, Tfol, $\mathrm{CO}_{2}$ ar, Umiar, Umicâ, PARi, PARo \\
\hline 10 & 8 VE: Tempo, Tar, Tfol, $\mathrm{CO}_{2}$ ar, $\mathrm{CO}_{2}$ câ, Umiar, Umicâ, PARo \\
\hline 11 & 8 VE: Tempo, Tar, Tfol, $\mathrm{CO}_{2}$ ar, $\mathrm{CO}_{2}$ câ, Umiar, Umicâ, PARi \\
\hline 12 & 8 VE: Tempo, Tfol, $\mathrm{CO}_{2}$ ar, $\mathrm{CO}_{2}$ câ, Umiar, Umicâ, PARi, PARo \\
\hline 13 & 8 VE: Tempo, Tar, $\mathrm{CO}_{2}$ ar, $\mathrm{CO}_{2} \mathrm{câ}$, Umiar, Umicâ, PARi, PARo \\
\hline 14 & 8 VE: Tar, Tfol, $\mathrm{CO}_{2}$ ar, $\mathrm{CO}_{2}$ câ, Umiar, Umicâ, PARi, PARo \\
\hline 15 & 8 VE: Tempo, Tar, Tfol, $\mathrm{CO}_{2}$ ar, $\mathrm{CO}_{2}$ câ, Umicâ, PARi, PARo \\
\hline 16 & 8 VE: Tempo, Tar, Tfol, $\mathrm{CO}_{2}$ ar, $\mathrm{CO}_{2}$ câ, Umiar, PARi, PARo \\
\hline 17 & $\begin{array}{l}9 \text { VE: Tempo, Tar, Tfol, } \mathrm{CO}_{2} \text { ar, } \mathrm{CO}_{2} \text { câ, Umiar, Umicâ, PARi, } \\
\text { PARo }\end{array}$ \\
\hline 18 & $\begin{array}{l}10 \text { VE: Tempo, Planta, Tar, Tfol, } \mathrm{CO}_{2} \mathrm{ar}, \mathrm{CO}_{2} \mathrm{câ}, \text { Umiar, Umicâ, } \\
\text { PARi, PARo }\end{array}$ \\
\hline
\end{tabular}

Observação: abreviatura das variáveis de entrada segundo a definição da tabela 4.8. 
Tabela 5.12 - Primeiro quadro dos casos treinados para modelar fotossíntese.

\begin{tabular}{|c|c|c|c|c|c|c|c|c|}
\hline \multirow[t]{2}{*}{ Casos } & \multicolumn{4}{|c|}{ Estrutura da rede } & \multicolumn{4}{|c|}{ Parâmetros de treinamento } \\
\hline & \begin{tabular}{|ll} 
Neurônios na \\
Camada de \\
Entrada
\end{tabular} & $\begin{array}{l}\text { Neur } \\
\text { Cam } \\
\text { Esco }\end{array}$ & $\begin{array}{l}\text { nios } \\
\text { las } \\
\text { didas }\end{array}$ & $\begin{array}{l}\text { Neur. } \\
\text { Cam. } \\
\text { Saída }\end{array}$ & $\begin{array}{l}\text { Itera- } \\
\text { ções } \\
\text { internas }\end{array}$ & \begin{tabular}{|l|} 
Iterações \\
externas \\
(globais)
\end{tabular} & $\begin{array}{l}\text { Coeficiente de } \\
\text { aprendizado }\end{array}$ & $\begin{array}{l}\text { Tole- } \\
\text { rân- } \\
\text { cia }\end{array}$ \\
\hline 1 & $6,7,8,9$ ou 10 & & & 1 & 5 & 3000 & 1.9 .8 & 0.01 \\
\hline 2 & $6,7,8,9$ ou 10 & & & 1 & 5 & 3000 & 1.9 .8 & 0.01 \\
\hline 3 & $6,7,8,9$ ou 10 & 15 & 15 & 1 & 5 & 6000 & 1.9 .8 & 0.01 \\
\hline 4 & $6,7,8,9$ ou 10 & 18 & 18 & 1 & 5 & 6000 & $\begin{array}{lll}1.9 & .8\end{array}$ & 0.01 \\
\hline 5 & $6,7,8,9$ ou 10 & 20 & 20 & 1 & 5 & 6000 & 1.9 .8 & 0.01 \\
\hline 6 & $6,7,8,9$ ou 10 & 25 & 25 & 1 & 5 & 6000 & 1.9 .8 & 0.01 \\
\hline 7 & $6,7,8,9$ ou 10 & 28 & 28 & 1 & 5 & 6000 & 1.9 .8 & 0.01 \\
\hline 8 & $6,7,8,9$ ou 10 & 30 & 30 & 1 & 5 & 6000 & 1.9 .8 & 0.01 \\
\hline 9 & $6,7,8,9$ ou 10 & 18 & 18 & 1 & 5 & 6000 & 1.95 .9 .85 .8 .78 & 0.01 \\
\hline 10 & $6,7,8,9$ ou 10 & 20 & 20 & 1 & 5 & 6000 & 1.95 .9 .85 .8 .78 & 0.01 \\
\hline 11 & $6,7,8,9$ ou 10 & $\mathrm{X}$ & $\mathrm{X}$ & 1 & 5 & 6000 & 1.95 .9 .85 .8 .75 & 0.01 \\
\hline 12 & $6,7,8,9$ ou 10 & $\mathrm{X}$ & $\mathrm{X}$ & 1 & 5 & 6000 & 1.96 .92 .88 .82 .78 & 0.01 \\
\hline 13 & $6,7,8,9$ ou 10 & $\mathrm{X}$ & $\mathrm{X}$ & 1 & 5 & 6000 & 1.97.94.91.88.85 & 0.01 \\
\hline 14 & $6,7,8,9$ ou 10 & $\mathrm{X}$ & $\mathrm{X}$ & 1 & 5 & 6000 & 1.98 .96 .94 .92 .90 & 0.01 \\
\hline 15 & $6,7,8,9$ ou 10 & $\mathrm{X}$ & $\mathrm{X}$ & 1 & 5 & 6000 & $\mid$\begin{tabular}{|c|}
1.99 .98 .97 .96 .95 \\
\end{tabular} & 0.01 \\
\hline 16 & $6,7,8,9$ ou 10 & $\mathrm{X}$ & $\mathrm{X}$ & 1 & 5 & 6000 & $\mid 94.92 .90 .88 .86 .84$ & 0.01 \\
\hline 17 & $6,7,8,9$ ou 10 & $\mathrm{X}$ & $\mathrm{X}$ & 1 & 5 & 6000 & $\mid 94.93 .92 .91 .90 .89$ & 0.01 \\
\hline 18 & $6,7,8,9$ ou 10 & $\mathrm{X}$ & $\mathrm{X}$ & 1 & 5 & 6000 & \begin{tabular}{|c|}
.94 .91 .88 .85 .82 .79 \\
\end{tabular} & 0.01 \\
\hline 19 & $6,7,8,9$ ou 10 & $\mathrm{X}$ & $\mathrm{X}$ & 1 & 5 & 6000 & 1.9 .8 & 0.001 \\
\hline 20 & $6,7,8,9$ ou 10 & $\mathrm{X}$ & $\mathrm{X}$ & 1 & 3 & 6000 & \begin{tabular}{ll|}
1.9 .8 \\
\end{tabular} & 0.001 \\
\hline 21 & $6,7,8,9$ ou 10 & $\mathrm{X}$ & $\mathrm{X}$ & 1 & 3 & 6000 & 1.9 .8 & 0.01 \\
\hline
\end{tabular}


Como se definiram 18 combinações de entrada, e 21 casos de estrutura de rede e parâmetros, o número de treinamentos realizados foi 378 para os dados do outono, nível 1.

Quando se começou a realizar os primeiros treinamentos observou-se que os resultados não eram tão satisfatórios, pelo que se analisaram esses resultados com mais detalhe. A faixa dos valores medidos de fotossíntese está entre -2,71 e 6,66 $\mu \mathrm{mol} \mathrm{CO} 2 \cdot \mathrm{m}^{-2} . \mathrm{s}^{-1}$. Observou-se que os erros do treinamento eram maiores, por causa dos valores de fotossíntese que estavam na faixa de $-0,099$ a $0,099 \mu \mathrm{mol} \mathrm{CO}_{2} \cdot \mathrm{m}^{-2} \cdot \mathrm{s}^{-1}$. Essa faixa de valores pequenos está relacionada com a calibração do medidor portátil de fotossíntese. Antes de começar as medidas de fotossíntese, o sistema de medida de fotossíntese era calibrado, ou seja, tinha se que obter valores de medida de fotossíntese aproximadamente iguais a zero; idealmente o valor obtido deveria ser zero. Portanto, o erro de calibração é um erro que já está implícito no treinamento das redes neurais.

Como exemplo, na Figura 5.13 são apresentadas as medidas de fotossíntese, na faixa de -0,099 a 0,099, correspondentes ao outono, nível 1; assim como também, os valores calculados pela rede neural. Na Figura 5.13b são apresentadas as medidas de fotossíntese, para mostrar as oscilações das medidas na faixa indicada, oscilações que estão relacionadas com a calibração do medidor de fotossíntese. Na Figura 5.13a são apresentadas as medidas de fotossíntese e os valores calculados pela rede neural, para mostrar que os valores obtidos pela rede neural também oscilam, e em uma faixa maior que os valores medidos. 


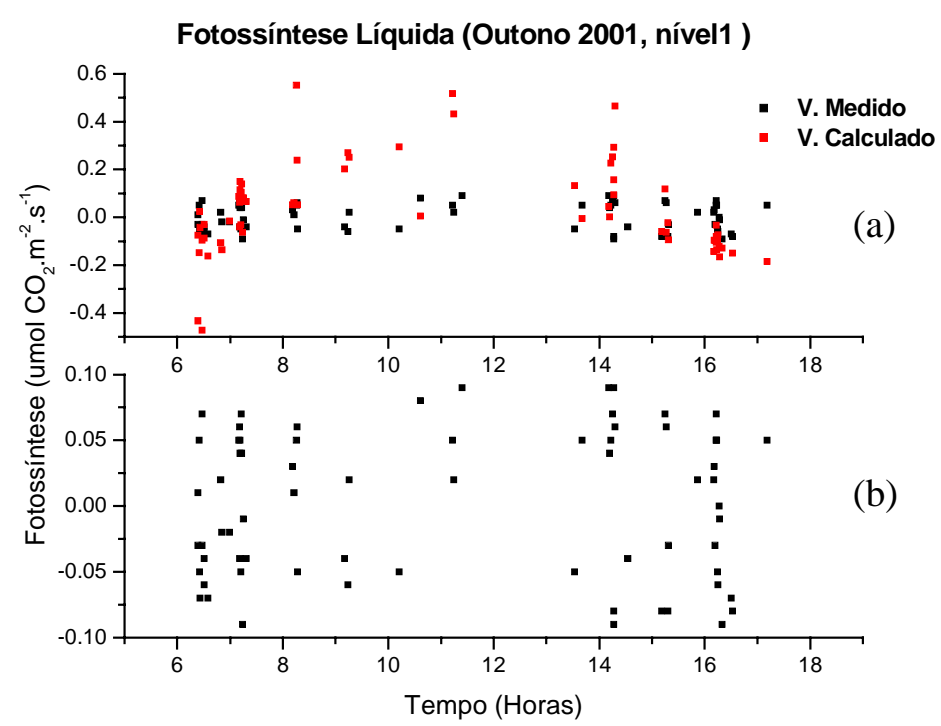

Figura 5.13 Fotossíntese (a) valores calculados pela ANN e valores medidos (b) Oscilações das medidas de fotossíntese na faixa de -0,099 a 0,099.

No item 4.2.3, mencionou-se que o programa utilizado para os treinamentos, MLP1b, calcula o erro de avaliação pela equação 4.2; ao calcular o erro para a faixa de valores indicados acima, produziam-se erros relativos grandes. Isto ocasionava que, no cálculo global do erro, os valores fossem maiores. Como exemplo, mostra-se o cálculo do erro de avaliação para um par de vetores entrada-saída, que corresponde ao resultado de um dos treinamentos com 6 variáveis de entrada.

Entrada $\quad 15.31800 \quad 31.12000 \quad 30.42000375 .10000 \quad 37.70000 \quad 9.00000$

Saída Real (valor medido) $\quad-0.03000$

Saída calculada pela rede $\quad-0.09447$

$$
\text { Erro }=a b s\left(\frac{-0,09447-(-0,03000)}{-0,03000}\right)=2,149=214,9 \%
$$

Como se observou que essa faixa de valores pequenos introduzia um erro considerável, foram realizados treinamentos sem o conjunto de dados na faixa de $-0,099$ a 0,099 , seguindo o mesmo procedimento que para o treinamento com todos 
os dados. Isto é, foram realizados treinamentos para as combinações de variáveis de entrada, da Tabela 5.11, e para o quadro dos casos treinados, da Tabela 5.12.

Portanto foram realizados dois conjuntos de treinamentos com os dados de outono, nível 1, primeiro conjunto, com todos os dados, e um segundo conjunto, com dados filtrados (sem os dados na faixa de $-0,099$ a $0,099 \mu \mathrm{mol} \mathrm{CO}_{2} \cdot \mathrm{m}^{-2} \cdot \mathrm{s}^{-1}$ ). Uma vez realizados esses treinamentos, selecionaram-se os casos com os que se obtiveram melhores resultados, menor erro: cinco casos do primeiro conjunto (treinamentos com todos os dados), e quatro casos do segundo conjunto (treinamentos com dados filtrados). Nas tabelas Tabela 5.13 e Tabela 5.14 são apresentados esses casos.

Tabela 5.13 - Segundo quadro dos casos treinados, primeiro conjunto (com todos os dados).

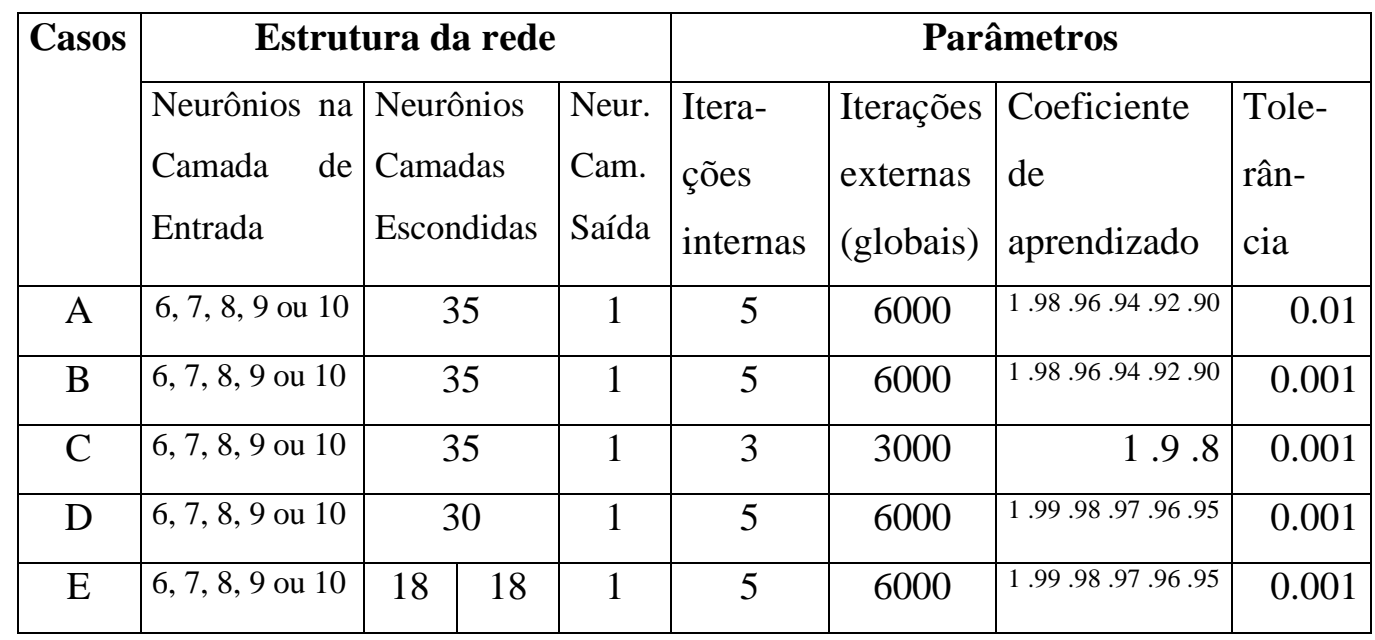

Para as configurações apresentadas nos quadros das tabelas Tabela $5.13 \mathrm{e}$ Tabela 5.14, e para as combinações de variáveis de entrada, Tabela 5.11, continuaram-se realizando os treinamentos para a estação do outono, níveis 2 e 3; e para as estações do inverno, da primavera e do verão, níveis 1, 2 e 3 . Foram 
realizados 1080 treinamentos $^{*}$ para o primeiro conjunto de treinamento, e $864^{+}$para o segundo conjunto.

Tabela 5.14 - Segundo quadro dos casos treinados, segundo conjunto (com dados filtrados).

\begin{tabular}{|c|c|c|c|c|c|c|c|}
\hline \multirow[t]{2}{*}{ Casos } & \multicolumn{3}{|c|}{ Estrutura da rede } & \multicolumn{4}{|c|}{ Parâmetros } \\
\hline & \begin{tabular}{|ll} 
Neurônios na \\
Camada de \\
Entrada
\end{tabular} & $\begin{array}{l}\text { Neurônios } \\
\text { Camadas } \\
\text { Escondidas }\end{array}$ & $\begin{array}{l}\text { Neur. } \\
\text { Cam. } \\
\text { Saída }\end{array}$ & $\begin{array}{l}\text { Itera- } \\
\text { ções } \\
\text { internas }\end{array}$ & $\begin{array}{l}\text { Iterações } \\
\text { externas } \\
\text { (globais) }\end{array}$ & $\begin{array}{l}\text { Coeficiente } \\
\text { de } \\
\text { aprendizado }\end{array}$ & $\begin{array}{l}\text { Tole- } \\
\text { rân- } \\
\text { cia }\end{array}$ \\
\hline A & $6,7,8,9$ ou 10 & 35 & 1 & 5 & 6000 & 1.99 .98 .97 .96 .95 & 0.01 \\
\hline B & $6,7,8,9$ ou 10 & 30 & 1 & 5 & 3000 & 1.9 .8 & 0.001 \\
\hline $\mathrm{C}$ & $6,7,8,9$ ou 10 & 35 & 1 & 3 & 6000 & 1.95 .90 .85 .80 .75 & 0.001 \\
\hline $\mathrm{D}$ & $6,7,8,9$ ou 10 & 15 & 1 & 5 & 6000 & 1.97 .94 .91 .88 .85 & 0.001 \\
\hline
\end{tabular}

Os números de vetores de treinamento e de teste utilizados na modelagem são apresentados na Tabela 5.15 e na Tabela 5.16, por estação e por nível: na Tabela 5.15 para o primeiro conjunto de treinamento, e na Tabela 5.16 para o segundo conjunto de treinamento.

Tabela 5.15 - Número de vetores de treinamento e de teste para o primeiro conjunto (com todos os dados).

\begin{tabular}{|l|c|c|c|c|c|c|c|c|c|c|c|c|}
\hline \multirow{2}{*}{} & \multicolumn{3}{|c|}{ Outono } & \multicolumn{3}{c|}{ Inverno } & \multicolumn{3}{c|}{ Primavera } & \multicolumn{3}{c|}{ Verão } \\
\cline { 2 - 12 } & N1 & N2 & N3 & N1 & N2 & N3 & N1 & N2 & N3 & N1 & N2 & N3 \\
\hline $\begin{array}{l}\text { Vetores } \\
\text { Treino }\end{array}$ & 500 & 500 & 500 & 560 & 560 & 560 & 490 & 490 & 490 & 520 & 520 & 520 \\
\hline $\begin{array}{l}\text { Vetores } \\
\text { Teste }\end{array}$ & 301 & 301 & 294 & 320 & 318 & 320 & 274 & 284 & 280 & 276 & 276 & 271 \\
\hline
\end{tabular}

N1: Nível 1, N2: Nível 2, N3: Nível 3

\footnotetext{
* 18 combinações * 5 casos * 3 níveis * 4 estações.

+ 18 combinações $* 4$ casos $* 3$ níveis $* 4$ estações.
} 
Tabela 5.16 - Número de vetores de treinamento e de teste para o segundo conjunto (com dados filtrados).

\begin{tabular}{|l|c|c|c|c|c|c|c|c|c|c|c|c|}
\hline & \multicolumn{3}{|c|}{ Outono } & \multicolumn{3}{c|}{ Inverno } & \multicolumn{3}{c|}{ Primavera } & \multicolumn{3}{c|}{ Verão } \\
\cline { 2 - 12 } & N1 & N2 & N3 & N1 & N2 & N3 & N1 & N2 & N3 & N1 & N2 & N3 \\
\hline $\begin{array}{l}\text { Vetores } \\
\text { Treino }\end{array}$ & 450 & 458 & 465 & 492 & 491 & 497 & 450 & 450 & 450 & 460 & 470 & 500 \\
\hline $\begin{array}{l}\text { Vetores } \\
\text { Teste }\end{array}$ & 236 & 250 & 250 & 290 & 290 & 295 & 227 & 240 & 245 & 229 & 234 & 238 \\
\hline
\end{tabular}

N1: Nível 1, N2: Nível 2, N3: Nível 3.

\subsubsection{Resultados}

Feitas essas considerações, a seguir são apresentados os resultados obtidos na primeira fase da modelagem do ciclo diário de fotossíntese, para cada uma das quatro estações e para os três níveis da planta.

Na Tabela 5.17 e na Tabela 5.18 são apresentados os casos com os que se obtiveram os melhores resultados: na Tabela 5.17, para o primeiro conjunto, treinamento com todos os dados, e na Tabela 5.18, para o segundo conjunto, treinamento com dados filtrados. Os casos mostrados nessas tabelas, representados pelas letras: A, B, C, D, e E, correspondem aos quadros da Tabela 5.13 e da Tabela 5.14 . 
Tabela 5.17 - Casos com os que se obtiveram os melhores resultados, primeiro conjunto de treinamento, com todos os dados.

\begin{tabular}{|c|c|c|c|c|c|c|c|c|c|c|c|c|}
\hline \multirow[t]{2}{*}{ Combinação* } & \multicolumn{3}{|c|}{ Outono } & \multicolumn{3}{|c|}{ Inverno } & \multicolumn{3}{|c|}{ Primavera } & \multicolumn{3}{|c|}{ Verão } \\
\hline & N1 & $\mathbf{N 2}$ & N3 & N1 & $\mathbf{N 2}$ & N3 & N1 & $\mathbf{N 2}$ & N3 & N1 & $\mathbf{N 2}$ & N3 \\
\hline 1 & $\mathrm{D}$ & B & B & A & $\mathrm{E}$ & A & $\mathrm{C}$ & $\mathrm{D}$ & $\mathrm{C}$ & $\mathrm{E}$ & $\mathrm{C}$ & $\mathrm{D}$ \\
\hline 2 & $\mathrm{E}$ & $\mathrm{D}$ & B & $\mathrm{E}$ & $\mathrm{E}$ & $\mathrm{B}$ & $\mathrm{C}$ & $\mathrm{E}$ & $\mathrm{D}$ & $\mathrm{E}$ & $\mathrm{C}$ & $\mathrm{C}$ \\
\hline 3 & $\mathrm{D}$ & $E$ & $E$ & $E$ & $\mathrm{E}$ & $\mathrm{B}$ & $E$ & $\mathrm{~B}$ & $\mathrm{~A}$ & $E$ & $\mathrm{E}$ & $E$ \\
\hline 4 & $\mathrm{E}$ & $\mathrm{D}$ & $E$ & $\mathrm{C}$ & $\mathrm{E}$ & $\mathrm{C}$ & $\mathrm{E}$ & $\mathrm{C}$ & $\mathrm{C}$ & $\mathrm{D}$ & $\mathrm{C}$ & $\mathrm{C}$ \\
\hline 5 & $\mathrm{D}$ & B & B & B & $\mathrm{E}$ & $\mathrm{C}$ & $\mathrm{E}$ & $\mathrm{E}$ & $\mathrm{C}$ & $\mathrm{D}$ & A & $\mathrm{E}$ \\
\hline 6 & B & $\mathrm{C}$ & $\mathrm{D}$ & $\mathrm{D}$ & $\mathrm{C}$ & $\mathrm{C}$ & $\mathrm{A}$ & $E$ & $\mathrm{D}$ & $\mathrm{E}$ & $\mathrm{B}$ & $\mathrm{C}$ \\
\hline 7 & $\mathrm{C}$ & $\mathrm{A}$ & $\mathrm{C}$ & B & $\mathrm{C}$ & $\mathrm{E}$ & $\mathrm{A}$ & $E$ & $\mathrm{D}$ & $\mathrm{C}$ & $\mathrm{B}$ & $\mathrm{C}$ \\
\hline 8 & $\mathrm{D}$ & B & $\mathrm{D}$ & $\mathrm{E}$ & $\mathrm{A}$ & $\mathrm{C}$ & B & $\mathrm{C}$ & $\mathrm{D}$ & $\mathrm{D}$ & $\mathrm{C}$ & $\mathrm{C}$ \\
\hline 9 & $\mathrm{D}$ & B & A & $\mathrm{D}$ & $\mathrm{C}$ & $\mathrm{C}$ & $\mathrm{E}$ & $\mathrm{E}$ & $\mathrm{D}$ & B & B & $\mathrm{C}$ \\
\hline 10 & $\mathrm{D}$ & $\mathrm{C}$ & B & $\mathrm{C}$ & $\mathrm{C}$ & B & D & $\mathrm{C}$ & $\mathrm{D}$ & B & $\mathrm{C}$ & B \\
\hline 11 & $\mathrm{D}$ & $\mathrm{C}$ & $\mathrm{E}$ & $\mathrm{C}$ & $\mathrm{C}$ & $\mathrm{E}$ & $\mathrm{C}$ & $\mathrm{C}$ & $\mathrm{D}$ & B & $\mathrm{E}$ & B \\
\hline 12 & B & B & $\mathrm{D}$ & $\mathrm{C}$ & $\mathrm{C}$ & $\mathrm{D}$ & B & $\mathrm{C}$ & $\mathrm{C}$ & B & B & B \\
\hline 13 & $\mathrm{D}$ & B & $\mathrm{D}$ & $\mathrm{C}$ & $\mathrm{C}$ & $\mathrm{D}$ & $\mathrm{D}$ & $\mathrm{C}$ & $\mathrm{D}$ & $\mathrm{B}$ & B & B \\
\hline 14 & B & $\mathrm{C}$ & B & $\mathrm{C}$ & $\mathrm{C}$ & $\mathrm{E}$ & $\mathrm{C}$ & $\mathrm{C}$ & $\mathrm{D}$ & B & $\mathrm{A}$ & A \\
\hline 15 & $\mathrm{C}$ & $\mathrm{C}$ & B & $\mathrm{D}$ & B & $\mathrm{E}$ & $\mathrm{A}$ & $\mathrm{E}$ & B & $\mathrm{C}$ & $\mathrm{A}$ & $\mathrm{C}$ \\
\hline 16 & B & $\mathrm{C}$ & $\mathrm{D}$ & $\mathrm{D}$ & B & $\mathrm{E}$ & A & B & $\mathrm{D}$ & $\mathrm{C}$ & B & $\mathrm{C}$ \\
\hline 17 & B & $\mathrm{A}$ & B & $\mathrm{C}$ & $\mathrm{C}$ & B & $\mathrm{C}$ & $\mathrm{C}$ & $\mathrm{D}$ & $\mathrm{D}$ & $\mathrm{D}$ & $\mathrm{D}$ \\
\hline 18 & $\mathrm{C}$ & B & $\mathrm{C}$ & $\mathrm{C}$ & $\mathrm{C}$ & $\mathrm{D}$ & B & B & $\mathrm{D}$ & B & $\mathrm{C}$ & B \\
\hline
\end{tabular}

* Conforme a Tabela 5.11.

N1: Nível 1, N2: Nível 2, N3: Nível 3.

A, B, C, D, E: casos conforme a Tabela 5.13. 
Tabela 5.18 - Casos com os que se obtiveram os melhores resultados, segundo conjunto de treinamento, com dados filtrados.

\begin{tabular}{|c|c|c|c|c|c|c|c|c|c|c|c|c|}
\hline \multirow[t]{2}{*}{ Combinação* } & \multicolumn{3}{|c|}{ Outono } & \multicolumn{3}{|c|}{ Inverno } & \multicolumn{3}{|c|}{ Primavera } & \multicolumn{3}{|c|}{ Verão } \\
\hline & N1 & $\mathbf{N} 2$ & N3 & N1 & $\mathbf{N} 2$ & N3 & N1 & N2 & N3 & N1 & N2 & N3 \\
\hline 1 & $\mathrm{C}$ & $\mathrm{A}$ & $\mathrm{C}$ & $\mathrm{D}$ & $\mathrm{D}$ & A & $\mathrm{D}$ & $\mathrm{D}$ & $\mathrm{D}$ & $\mathrm{D}$ & $\mathrm{D}$ & $\mathrm{D}$ \\
\hline 2 & $\mathrm{C}$ & $\mathrm{A}$ & $\mathrm{A}$ & $\mathrm{D}$ & $\mathrm{D}$ & $\mathrm{D}$ & $\mathrm{C}$ & $\mathrm{D}$ & $\mathrm{C}$ & $\mathrm{A}$ & $\mathrm{D}$ & $\mathrm{D}$ \\
\hline 3 & $\mathrm{C}$ & $\mathrm{B}$ & $\mathrm{C}$ & $\mathrm{D}$ & $\mathrm{D}$ & $\mathrm{D}$ & $\mathrm{D}$ & $\mathrm{C}$ & $\mathrm{C}$ & $\mathrm{D}$ & $\mathrm{D}$ & $\mathrm{A}$ \\
\hline 4 & $\mathrm{~A}$ & $\mathrm{~A}$ & B & $\mathrm{D}$ & $\mathrm{C}$ & $\mathrm{D}$ & $\mathrm{D}$ & $\mathrm{D}$ & $\mathrm{C}$ & A & $\mathrm{D}$ & $\mathrm{D}$ \\
\hline 5 & $\mathrm{C}$ & A & $\mathrm{C}$ & $\mathrm{D}$ & $\mathrm{D}$ & $\mathrm{D}$ & $\mathrm{D}$ & $\mathrm{D}$ & $\mathrm{C}$ & $\mathrm{D}$ & $\mathrm{D}$ & $\mathrm{D}$ \\
\hline 6 & $\mathrm{C}$ & $\mathrm{B}$ & $\mathrm{C}$ & $\mathrm{D}$ & $\mathrm{C}$ & $\mathrm{D}$ & $\mathrm{D}$ & $\mathrm{B}$ & $\mathrm{D}$ & $\mathrm{C}$ & $\mathrm{C}$ & $\mathrm{B}$ \\
\hline 7 & $\mathrm{D}$ & $\mathrm{C}$ & $\mathrm{C}$ & $\mathrm{C}$ & $\mathrm{C}$ & $\mathrm{D}$ & $\mathrm{B}$ & $\mathrm{C}$ & $\mathrm{C}$ & $\mathrm{C}$ & $\mathrm{D}$ & $\mathrm{A}$ \\
\hline 8 & $\mathrm{~A}$ & $\mathrm{~B}$ & $\mathrm{C}$ & B & $\mathrm{C}$ & $\mathrm{C}$ & $\mathrm{D}$ & $\mathrm{A}$ & $\mathrm{C}$ & $\mathrm{C}$ & $\mathrm{D}$ & $\mathrm{D}$ \\
\hline 9 & $\mathrm{C}$ & B & $\mathrm{C}$ & $\mathrm{C}$ & $\mathrm{C}$ & A & $\mathrm{D}$ & $\mathrm{C}$ & $\mathrm{D}$ & $\mathrm{C}$ & $\mathrm{D}$ & $\mathrm{D}$ \\
\hline 10 & $\mathrm{C}$ & $\mathrm{C}$ & $\mathrm{C}$ & $\mathrm{C}$ & B & $\mathrm{C}$ & $\mathrm{C}$ & B & $\mathrm{C}$ & $\mathrm{C}$ & $\mathrm{C}$ & $\mathrm{C}$ \\
\hline 11 & $\mathrm{C}$ & $\mathrm{C}$ & $\mathrm{C}$ & $\mathrm{D}$ & $\mathrm{C}$ & $\mathrm{C}$ & $\mathrm{C}$ & B & $\mathrm{C}$ & $\mathrm{C}$ & $\mathrm{C}$ & B \\
\hline 12 & $\mathrm{C}$ & $\mathrm{C}$ & $\mathrm{C}$ & $\mathrm{C}$ & $\mathrm{C}$ & $\mathrm{C}$ & $\mathrm{C}$ & B & $\mathrm{C}$ & $\mathrm{C}$ & B & $\mathrm{C}$ \\
\hline 13 & $\mathrm{C}$ & $\mathrm{C}$ & $\mathrm{C}$ & B & $\mathrm{C}$ & $\mathrm{C}$ & $\mathrm{C}$ & B & B & $\mathrm{C}$ & B & B \\
\hline 14 & $\mathrm{C}$ & $\mathrm{D}$ & $\mathrm{C}$ & B & $\mathrm{C}$ & $\mathrm{C}$ & $\mathrm{C}$ & B & $\mathrm{C}$ & $\mathrm{C}$ & $\mathrm{C}$ & B \\
\hline 15 & $\mathrm{~B}$ & $\mathrm{D}$ & $\mathrm{C}$ & $\mathrm{C}$ & $\mathrm{C}$ & $\mathrm{C}$ & $\mathrm{D}$ & B & $\mathrm{B}$ & $\mathrm{C}$ & $\mathrm{C}$ & $\mathrm{A}$ \\
\hline 16 & $\mathrm{C}$ & $\mathrm{D}$ & $\mathrm{C}$ & $\mathrm{C}$ & $\mathrm{C}$ & $\mathrm{C}$ & $\mathrm{D}$ & $\mathrm{C}$ & $\mathrm{C}$ & $\mathrm{C}$ & $\mathrm{D}$ & B \\
\hline 17 & $\mathrm{C}$ & $\mathrm{C}$ & $\mathrm{C}$ & B & $\mathrm{C}$ & $\mathrm{C}$ & $\mathrm{C}$ & B & B & $\mathrm{D}$ & B & $\mathrm{C}$ \\
\hline 18 & $\mathrm{D}$ & $\mathrm{C}$ & $\mathrm{C}$ & $\mathrm{D}$ & $\mathrm{C}$ & $\mathrm{C}$ & $\mathrm{C}$ & B & $\mathrm{C}$ & $\mathrm{C}$ & $\mathrm{C}$ & $\mathrm{C}$ \\
\hline
\end{tabular}

* Conforme a Tabela 5.11.

N1: Nível 1, N2: Nível 2, N3: Nível 3.

A, B, C, D: casos conforme a Tabela 5.14.

Nas tabelas A.1 a A.16, do apêndice A, apresentam-se os erros obtidos, tanto no treinamento como no teste, para as quatro estações e para os três níveis. Nessas tabelas são apresentados o erro relativo médio, o desvio padrão e o erro relativo máximo. Essas tabelas apresentam os melhores resultados obtidos para as 18 
combinações de variáveis de entrada, os quais correspondem aos casos mostrados na Tabela 5.17 e na Tabela 5.18.

Nas tabelas A.1, A.3, A.5 e A.7 são apresentados os erros obtidos no treinamento, para o primeiro conjunto. A tabela A.1 mostra o resultado correspondente à estação do outono, a tabela A.3 apresenta o resultado do inverno, a tabela A.5 apresenta o resultado da primavera, e a tabela A.7 mostra o resultado do verão. Os erros obtidos no teste desses treinamentos são apresentados nas tabelas A.2, A.4, A.6 e A.8 respectivamente.

De igual maneira, os erros obtidos no treinamento, para o segundo conjunto, são mostrados nas tabelas A.9, A.11, A.13 e A.15; e os respectivos erros obtidos no teste são apresentados nas tabelas A.10, A.12, A.14 e A.16.

Observando os erros, em cada uma das tabelas, Tabela A.1 a A.16 do apêndice A, pode-se notar que se formam três grupos. Um primeiro grupo formado pelas combinações 1, 2, 3, 4, 5, 8 e 9, um segundo grupo formado pelas combinações 6, 7, 15 e 16, e um terceiro grupo formado pelas combinações 10, 11, 12, 13, 14, 17 e 18. Em cada um desses grupos observa-se que o erro relativo médio, o desvio padrão e o erro relativo máximo são similares. O primeiro grupo apresenta os maiores erros, o segundo grupo apresenta erros menores que o primeiro grupo, e o terceiro grupo apresenta os menores erros. Os que escapam desse padrão são os resultados do nível 3 , do primeiro conjunto, da primavera e do verão, onde observa-se que se formam dois grupos. Um grupo formado pelas combinações 1, 2, 3, 4, 5, 6, 7, 8, 9, 15 e 16, os quais apresentam os maiores erros; e outro grupo formado pelas combinações 10, 11, $12,13,14,17$ e 18 , os quais apresentam os menores erros.

Como se formaram três grupos, na maioria dos resultados apresentados, e em cada grupo os erros são similares, foi selecionada uma combinação de cada grupo, para mostrar a modelagem do ciclo diário de fotossíntese. A combinação 1 do primeiro grupo, a combinação 6 do segundo grupo, e a combinação 11 do terceiro grupo. 
A seguir serão apresentados os resultados da modelagem do ciclo diário de fotossíntese, para as três combinações de variáveis de entrada mencionadas acima. Serão apresentados, unicamente, os resultados correspondentes à estação do outono, nível 1, pois os resultados dos demais níveis e das demais estações mostram um comportamento similar.

Na Figura 5.14, na Figura 5.15 e na Figura 5.16 são mostrados os resultados dessas modelagens. Nessas figuras são apresentados os gráficos com os valores de fotossíntese calculados pelas redes neurais, pontos vermelhos, e os gráficos com os valores de fotossíntese medidos, pontos pretos. Em cada uma dessas figuras são mostrados os resultados do treinamento com os respectivos resultados do teste, tanto do primeiro como do segundo conjunto de treinamento. Na Figura 5.14 são apresentados os resultados da combinação 1, com 6 variáveis de entrada. Na Figura 5.15 estão os resultados da combinação 6, com 7 variáveis de entrada. Na Figura 5.16 são mostrados os resultados da combinação 11, com 8 variáveis de entrada.

Essas figuras corroboraram o mencionado anteriormente, que os resultados do primeiro grupo, representado pela combinação 1, apresentam os maiores erros. Isto pode ser observado nos gráficos da Figura 5.14, onde se nota que existe maior dispersão entre os valores calculados pelas ANNs, pontos vermelhos, e os valores medidos, pontos pretos. No segundo grupo, representado pela combinação 6, os erros são menores que no primeiro grupo, observar a Figura 5.15. Nessa figura se nota que a dispersão entre os valores calculados e os valores medidos é menor. A combinação 11, que representa o terceiro grupo, apresenta os menores erros. Na Figura 5.16 pode-se observar que existe uma menor dispersão entre os valores calculados pelas ANNs e os valores medidos. 
a) Com todos os dados
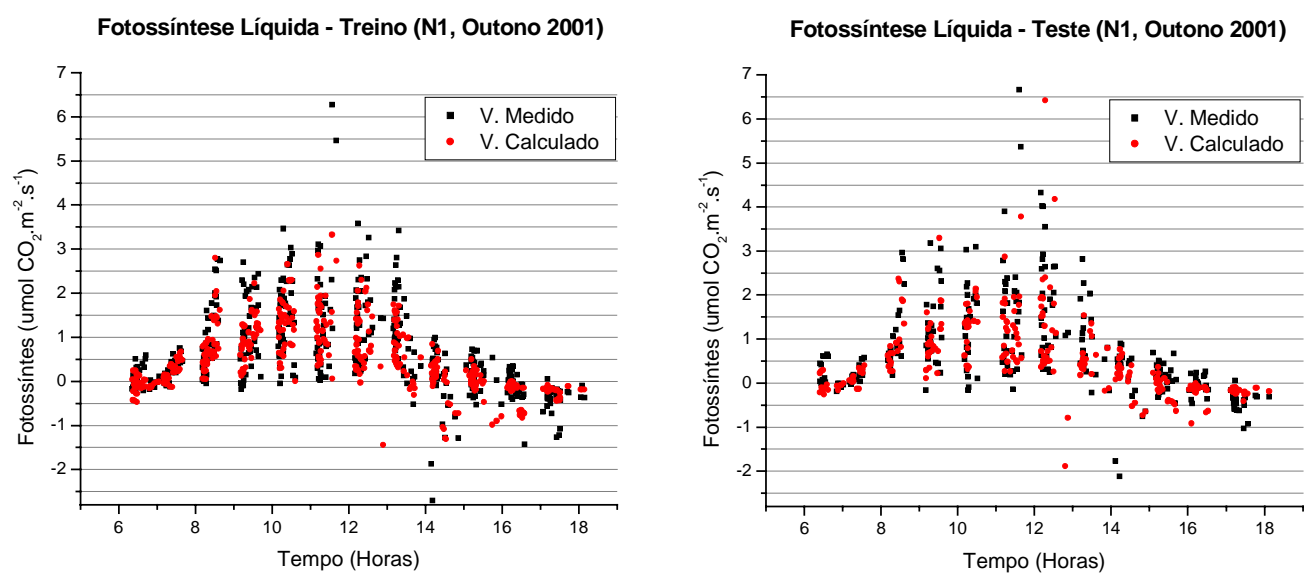

b) Com dados filtrados
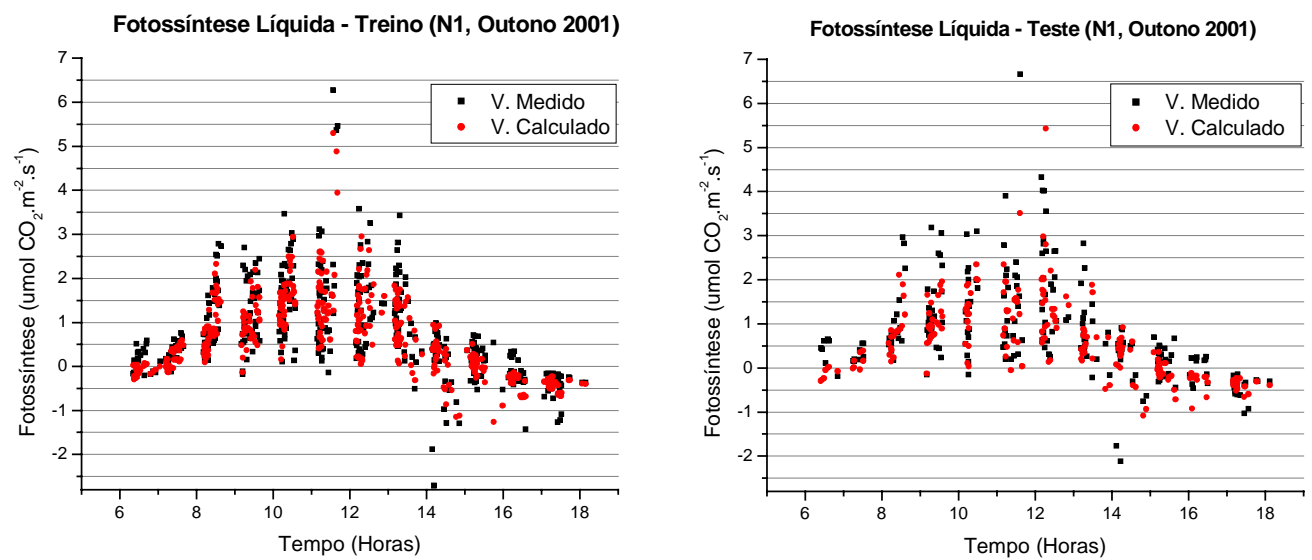

Figura 5.14 Resultados da modelagem do ciclo diário de fotossíntese para a combinação 1 (6 variáveis de entrada). 
a) Com todos os dados
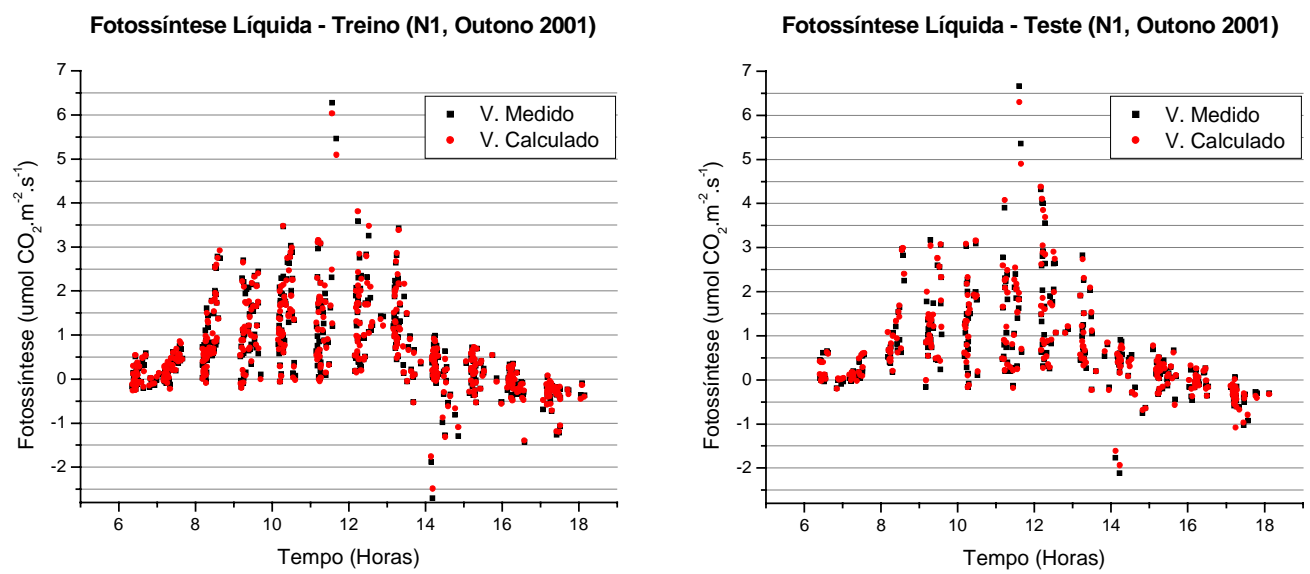

b) Com dados filtrados
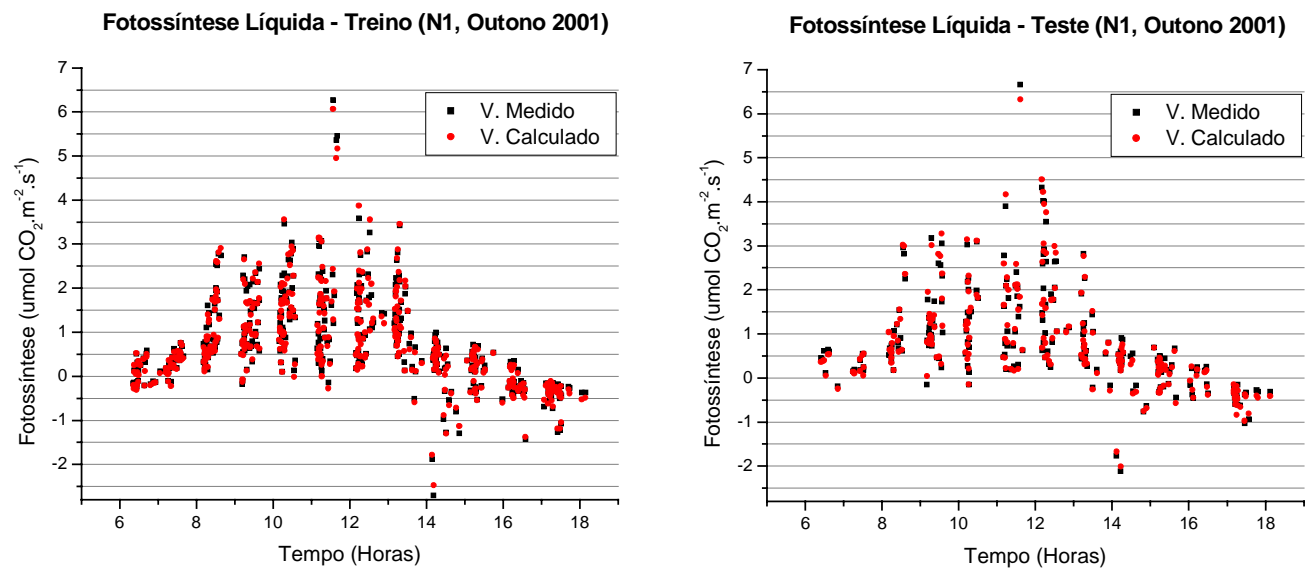

Figura 5.15 Resultados da modelagem do ciclo diário de fotossíntese para a combinação 6 (7 variáveis de entrada). 
a) Com todos os dados
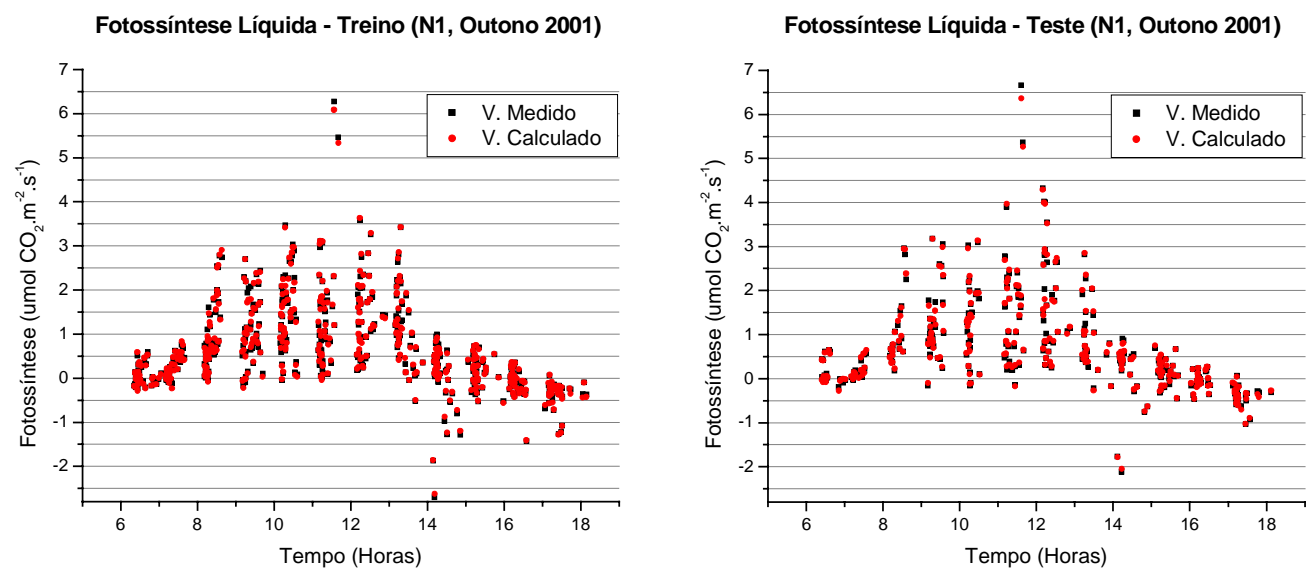

b) Com dados filtrados
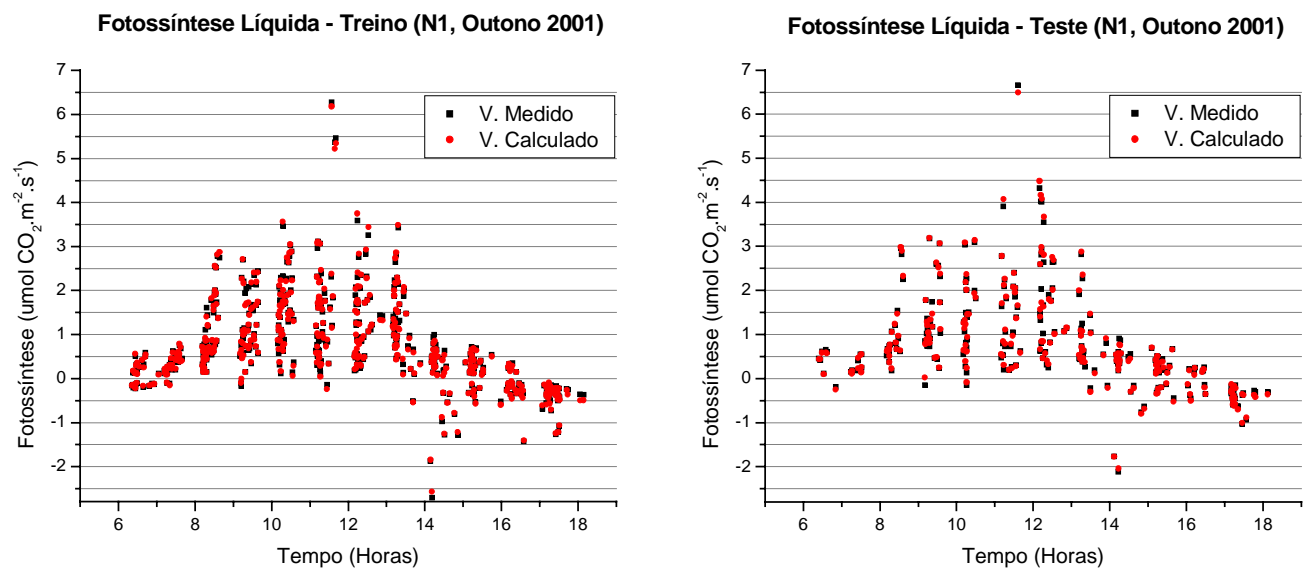

Figura 5.16 Resultados da modelagem do ciclo diário de fotossíntese para a combinação 11 (8 variáveis de entrada).

Na Tabela 5.19 e na Tabela 5.20 são apresentadas, como exemplo, as listas parciais dos resultados do treinamento e teste da combinação 1, correspondentes ao primeiro conjunto, treinamento com todos os dados, à estação do outono, e ao nível 1. Nessas tabelas, Tabela 5.19, treinamento, e Tabela 5.20, teste, são apresentados os valores das 6 variáveis de entrada, o valor da variável de saída real, e o valor da variável de saída calculada pela rede. Nessas tabelas nota-se a grande diferença entre o valor medido e valor calculado pela ANN, especialmente nos valores na faixa de -1 a 1. 
Tabela 5.19 - Lista parcial dos resultados do treinamento para a combinação 1 (6 variáveis de entrada), primeiro conjunto (com todos os dados).

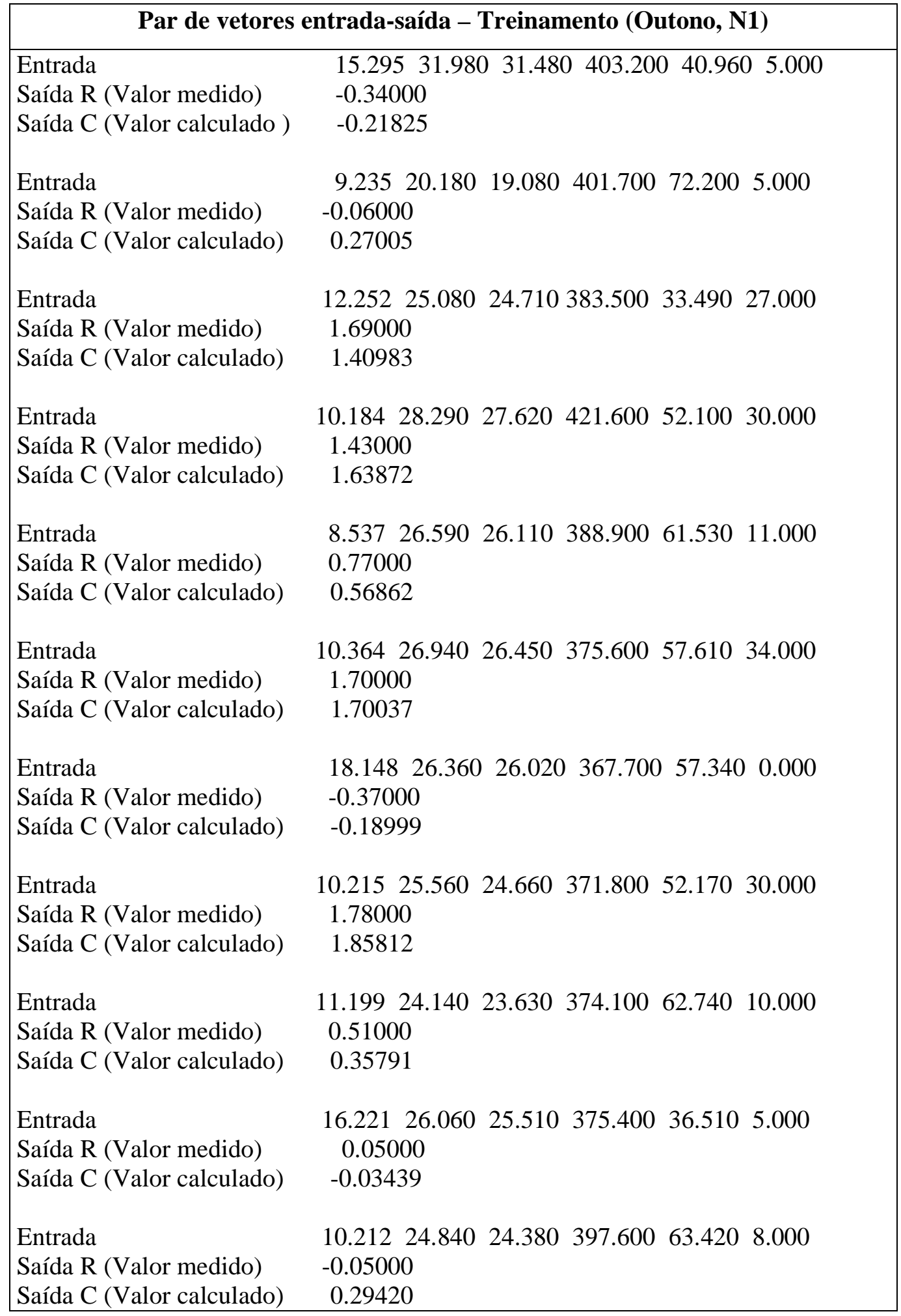


Tabela 5.20 - Lista parcial dos resultados do teste para a combinação 1 (6 variáveis de entrada), primeiro conjunto (com todos os dados).

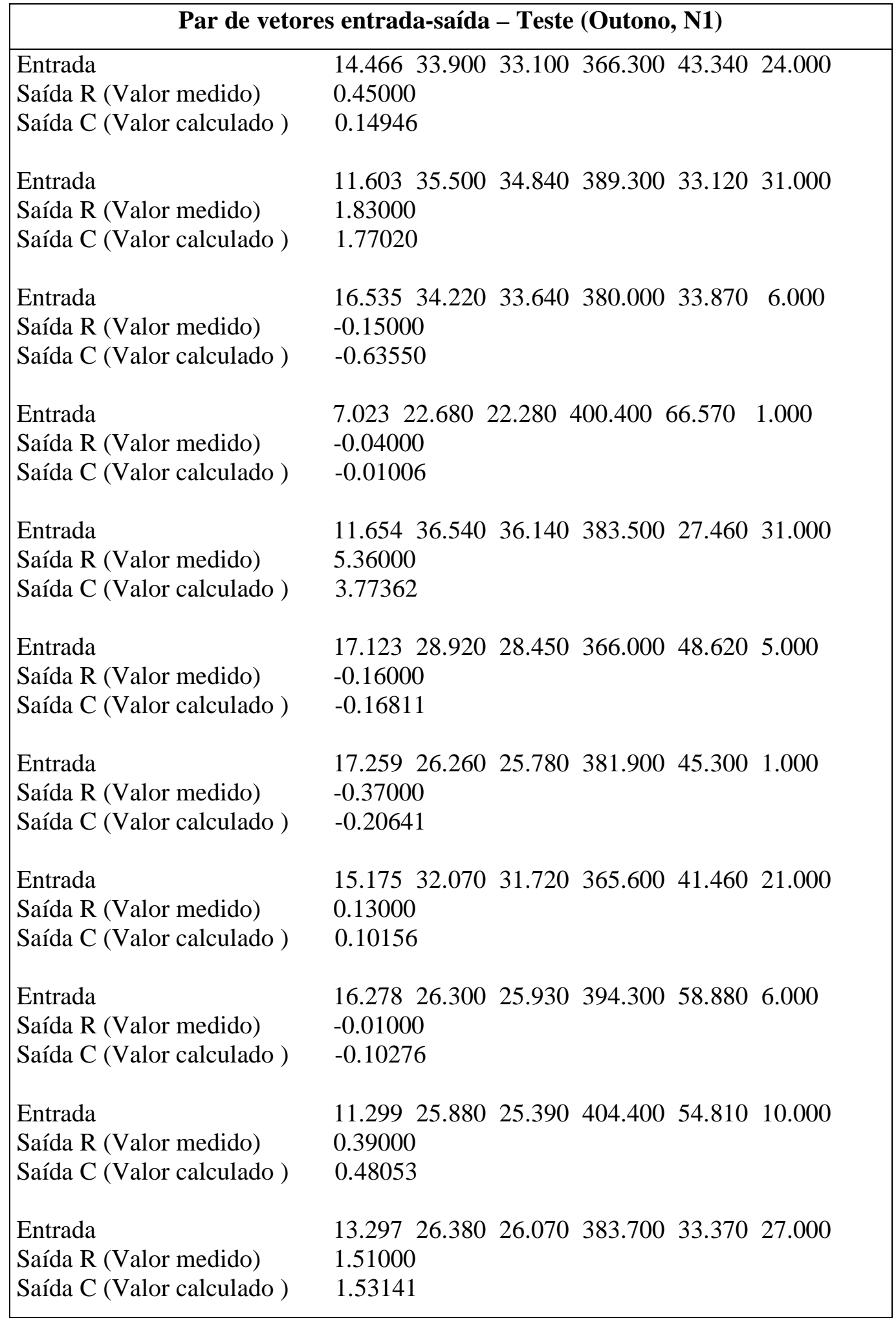


As listas parciais dos resultados do treinamento e teste, das combinações 6 e 11, do primeiro conjunto de treinamento, são mostradas em tabelas do apêndice A (Tabela A.17 a Tabela A.20); e nas tabelas subseqüentes (Tabela A.21 a Tabela A.26), são mostradas as listas parciais correspondentes ao segundo conjunto de treinamento, combinações 1, 6 e 11. As listas parciais apresentadas nas tabelas do Apêndice A (Tabela A.17 a Tabela A.26) também são os resultados da estação do outono e do nível 1. Nessas tabelas observa-se as diferenças entre o valor calculado pela ANN e o valor medido; a aproximação é melhor com a combinação 6, e melhor ainda com a combinação 11.

\subsubsection{Análise dos resultados}

Nas tabelas A.1 a A.16, do apêndice A, foram apresentados os erros obtidos tanto no treinamento como no teste das ANNs. Nessas tabelas foram mostrados os resultados correspondentes às 4 estações, aos 3 níveis e às 18 combinações de variáveis de entrada. A seguir serão analisados esses resultados. A análise compreenderá os seguintes pontos:

a) Influência das combinações de variáveis de entrada

b) Resultados do primeiro e do segundo conjunto de treinamento

c) Resultados por estação e por nível

d) Teste das ANNs

Além desses pontos, também, serão analisados:

e) Convergência das ANNs

f) Tempo de treinamento e teste

\section{a) Influência das combinações de variáveis de entrada}

No item 5.2.1.1, considerações iniciais, mencionou-se que foram realizados treinamentos com 18 combinações de variáveis de entrada, mostradas na Tabela 
5.11, porque se desejava avaliar que variáveis de entrada, mostradas na Tabela 4.1, influíam mais na modelagem de fotossíntese com ANNs. Neste item serão analisados esses resultados. Isto é, qual foi a influência das variáveis de entrada nos resultados do treinamento.

Na Figura 5.17 e na Figura 5.18 são apresentados gráficos do erro relativo médio dos treinamentos, das 18 combinações de variáveis de entrada, dos três níveis, para as 4 estações. Na Figura 5.17 são mostrados os resultados correspondentes ao primeiro conjunto, treinamento com todos os dados, e na Figura 5.18 os resultados do segundo conjunto, treinamento com dados filtrados.

Observando os gráficos dessas figuras, nota-se a formação de 3 grupos nas 18 combinações de variáveis de entrada, tanto no primeiro conjunto de treinamento, Figura 5.17, como no segundo conjunto de treinamento, Figura 5.18. Um primeiro grupo, formado pelas combinações 1, 2, 3, 4, 5, 8 e 9. Um segundo grupo, formado pelas combinações $6,7,15$ e 16. Um terceiro grupo, formado pelas combinações 10 , $11,12,13,14,17$ e 18. Em cada um desses grupos o erro relativo médio é similar. O primeiro grupo apresenta os maiores erros, o segundo grupo mostra menores erros que o primeiro grupo, e o terceiro grupo apresenta os menores erros. Escapam desse padrão os gráficos da primavera e do verão, nível 3, primeiro conjunto de treinamento, nos quais formam-se dois grupos. Um grupo formado pelas combinações $1,2,3,4,5,6,7,8,9,15$ e 16, que apresentam os maiores erros, e outro grupo formado pelas combinações 10,11, 12, 13, 14, 17 e 18, que apresentam os menores erros. Estas observações corroboram o mencionado no item 5.2.1.2, resultados, que se formavam grupos de combinações, com base na observação das tabelas.

A formação de três grupos de combinações nos resultados do treinamento, cada um com erros similares, indica que há algo em comum em cada grupo. As combinações 1, 2, 3, e 4 estão formadas por 6 variáveis de entrada (Tabela 5.11, combinações de variáveis de entrada). As primeiras três variáveis são as mesmas, o que varia são as últimas três variáveis. Essas últimas variáveis foram medidas tanto 
na câmara como fora da câmara, no ar. $\mathrm{O}$ propósito das primeiras quatro combinações foi avaliar a influência das variáveis medidas no ar e na câmara. Observando os resultados das primeiras quatro combinações, nos gráficos da Figura 5.17 e da Figura 5.18, primeiro e segundo conjunto de treinamento, nota-se que não há uma diferença significativa entre os resultados desses treinamento. Por conseguinte, os resultados indicam que não houve uma influência preponderante das variáveis medidas no ar ou das variáveis medidas na câmara.
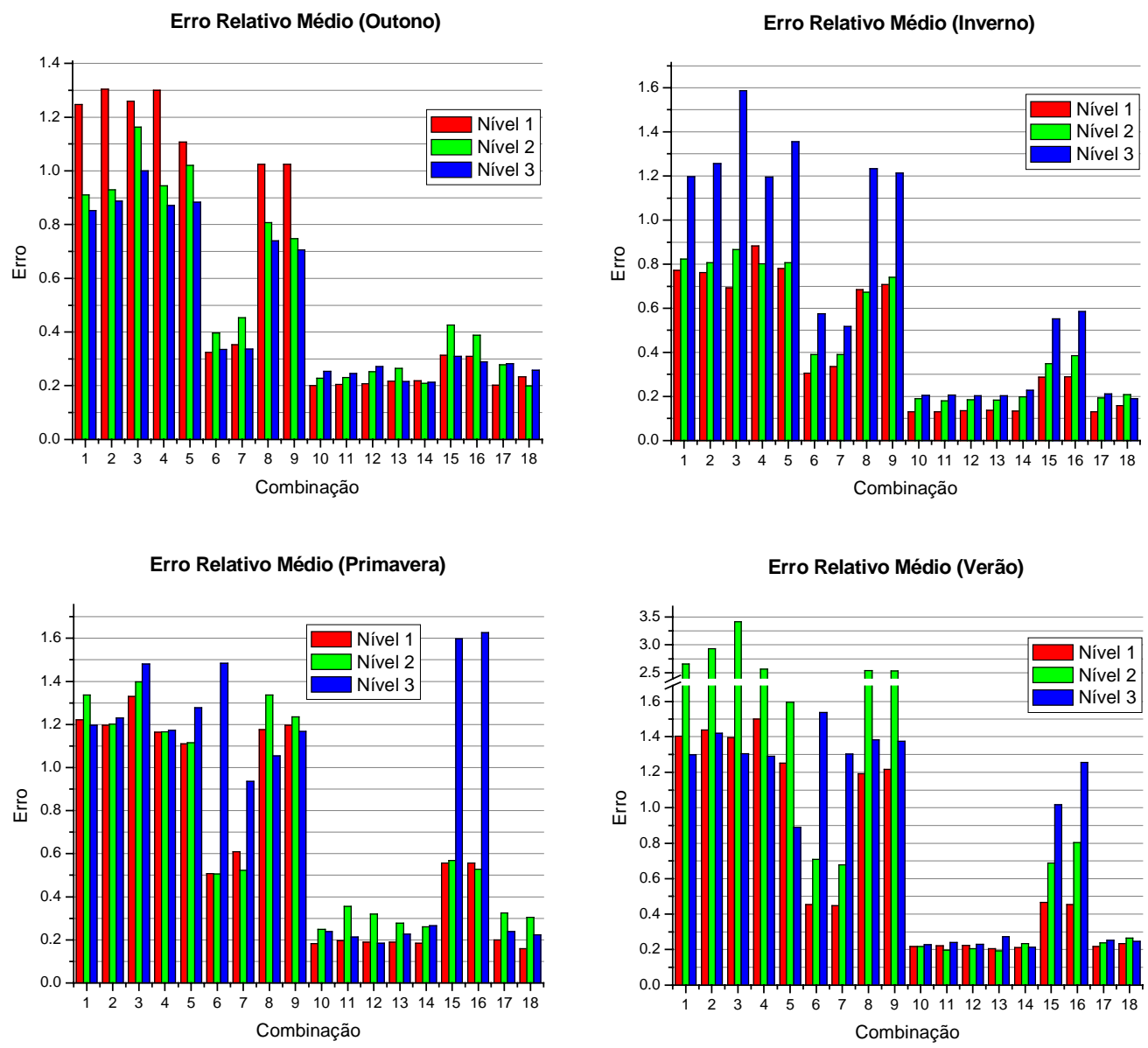

Figura 5.17 Resultados dos treinamentos, das 18 combinações de variáveis de entrada, do primeiro conjunto de treinamento. 

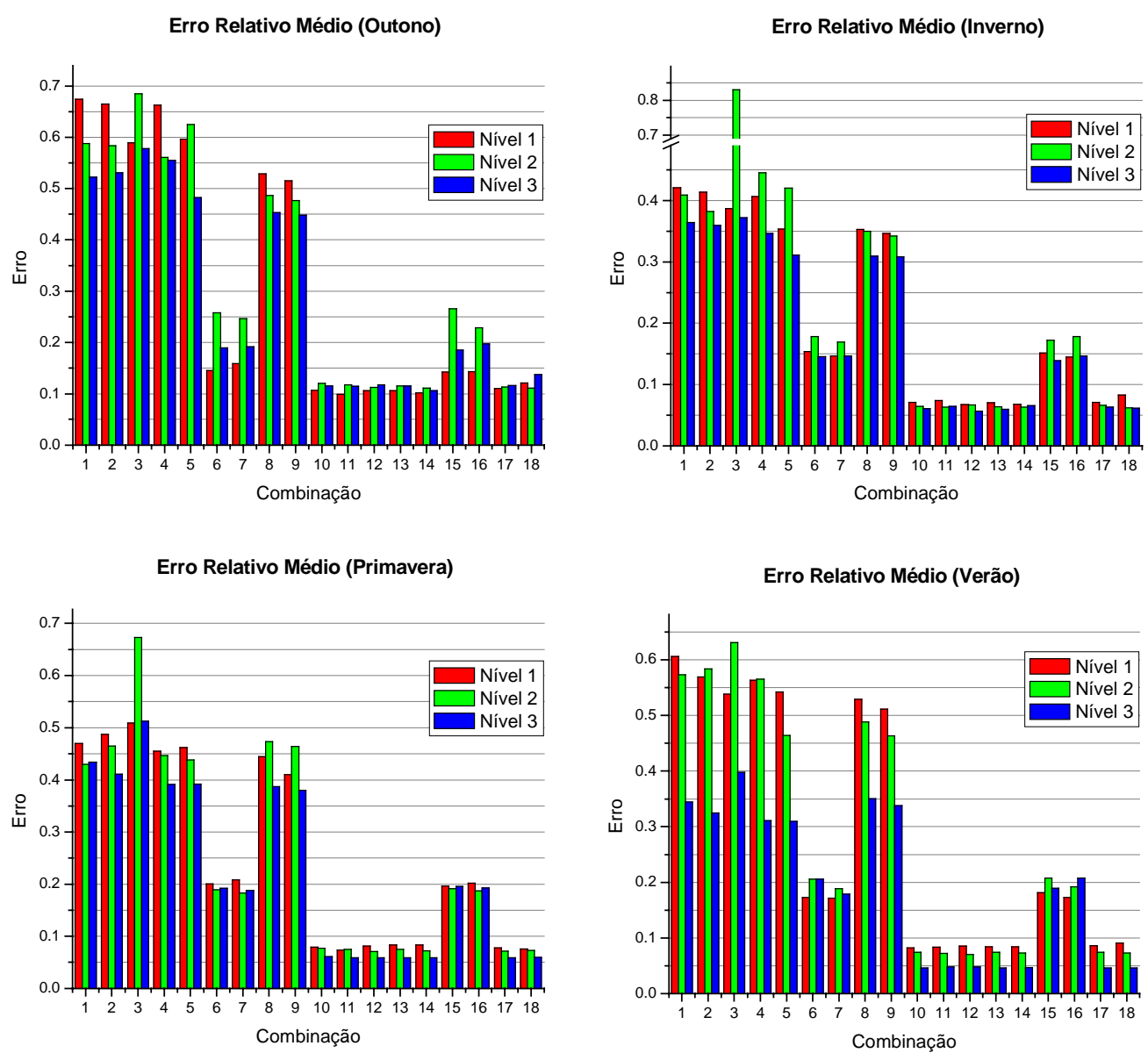

Figura 5.18 Resultados dos treinamentos, das 18 combinações de variáveis de entrada, segundo conjunto de treinamento.

A combinação 5 está formada pelas variáveis da combinação 1, além da variável planta. Neste caso, desejava-se avaliar a influência de distinguir as oito plântulas, em que foram realizadas as medidas. Observando os resultados da combinação 5 nos gráficos da Figura 5.17 e da Figura 5.18, nota-se que os resultados são semelhantes aos resultados das combinações 1, 2, 3 e 4. Portanto, os resultados mostram que não é necessário distinguir as plântulas que foram utilizadas no experimento. 
A combinação 6 , formada pelas variáveis da combinação 1 mais a variável concentração de $\mathrm{CO}_{2}$ na câmara, e a combinação 7, formada pelas variáveis da combinação 6, além da variável planta, apresentaram melhores resultados que as primeiras cinco combinações. Nos gráficos da Figura 5.17 e da Figura 5.18 nota-se que os erros apresentados pelas combinações 6 e 7 são significativamente menores que os erros das combinações 1, 2, 3, 4 e 5. Nas combinações 6 e 7 estão presentes as duas variáveis de concentração de $\mathrm{CO}_{2}$, do ar e da câmara. Isso indica que a diferença das duas variáveis de concentração de $\mathrm{CO}_{2}$ tem uma influência significativa nos resultados do treinamento.

As combinações 8 e 9 são formadas por 8 das 9 variáveis de entrada medidas. $\mathrm{Na}$ combinação 8 não está presente a variável concentração de $\mathrm{CO}_{2}$ do ar, e na combinação 9 não está presente a variável concentração de $\mathrm{CO}_{2}$ na câmara (Tabela 5.11). Observando os resultados dessas combinações nos gráficos, Figura 5.17 e Figura 5.18, nota-se que o erro diminui um pouco em comparação com as combinações 1, 2, 3, 4 e 5. Isso mostra que as duas variáveis de umidade relativa, do ar e da câmara, e/ou as duas variáveis de radiação fotossintética ativa, medidas na câmara e fora da câmara, influíram nessa diminuição do erro.

Para elucidar se as duas variáveis de umidade relativa, do ar e da câmara, influíram na diminuição do erro das combinações 8 e 9 , foram realizados treinamentos com as combinações 10 e 11. Nessas combinações estão presentes as duas variáveis de concentração de $\mathrm{CO}_{2}$, do ar e da câmara, e as duas variáveis de umidade relativa, do ar e da câmara (Tabela 5.11). Os resultados com as combinações 10 e 11 foram significativamente melhores que com as combinações 1 , 2, 3, 4, 5, 8 e 9; e melhores que as combinações 6 e 7 (Figura 5.17 e Figura 5.18). Isso indica que a diferença das variáveis de umidade relativa, do ar e da câmara, influi apreciavelmente nos resultados do treinamento.

O propósito das combinações 12, 13 e 14 foi o de avaliar a influência das variáveis temperatura do ar, temperatura da folha e tempo, respectivamente. $\mathrm{Na}$ Tabela 5.11 pode ser observado que na combinação 12 não está presente a variável 
temperatura do ar, na combinação 13 não está a variável temperatura da folha, e na combinação 14 não está presente a variável tempo. Comparando os resultados dessas combinações com os resultados das combinações 10 e 11, nos gráficos da Figura 5.17 e da Figura 5.18, nota-se que o erro não aumenta por causa da ausência de uma delas. Isso mostra que não há uma influência significativa das variáveis: temperatura do ar, temperatura da folha e tempo, nos resultados do treinamento.

Para avaliar a influência da diferença das variáveis de radiação fotossintética ativa, medidas na câmara e fora da câmara, e sem a presença da diferença das variáveis de umidade relativa, do ar e da câmara, foram realizados treinamentos com as combinações 15 e 16 (Tabela 5.11). Observando os resultados dessas combinações, nos gráficos da Figura 5.17 e da Figura 5.18, nota-se que o erro aumenta em comparação com os resultados das combinações 10, 11, 12, 13 e 14, nas quais estão presentes as duas variáveis de concentração de $\mathrm{CO}_{2}$ e as duas variáveis de umidade relativa; e é similar aos resultados das combinações 6 e 7, nas quais estão presentes as duas variáveis de concentração de $\mathrm{CO}_{2}$. Isso mostra que não há influência significativa da diferença das variáveis de radiação fotossintética ativa, medidas na câmara e fora da câmara; e evidencia a influência da diferença das variáveis de umidade relativa, do ar e da câmara.

Finalmente foram realizados treinamentos com a combinação 17, formada pelas 9 variáveis de entrada medidas, e a combinação 18, formada pelas variáveis da combinação 17 mais a variável planta. Comparando os resultados dessas combinações, com os resultados das combinações 10,11, 12, 13 e 14, nota-se que os resultados são similares (Figura 5.17 e Figura 5.18).

Em resumo, a análise dos resultados das 18 combinações de variáveis de entrada mostra que a diferença das variáveis de concentração de $\mathrm{CO}_{2}$, do ar e da câmara, influi significativamente nos resultados do treinamento. Isso é compreensível porque a fotossíntese é realizada com o $\Delta \mathrm{CO}_{2}\left(\mathrm{CO}_{2}\right.$ do ar $-\mathrm{CO}_{2}$ na câmara). A diferença das variáveis de umidade relativa, do ar e da câmara, também influi apreciavelmente nos resultados do treinamento, mas, em menor grau. Essa 
influência, possivelmente, relaciona-se com a transpiração da planta. pois a transpiração da planta contribui com o aumento da umidade do ambiente, neste caso, a câmara onde foi realizada a medida.

Quando, nas combinações, só esteve presente uma das variáveis de concentração de $\mathrm{CO}_{2}$, do ar ou da câmara, não houve influência significativa na qualidade dos resultados do treinamento. De igual maneira, quando só esteve presente, nas combinações, uma das variáveis de umidade relativa, do ar ou da câmara, também não houve influência significativa nos resultados do treinamento.

A análise dos resultados também mostra que as variáveis de entrada: tempo, planta, temperatura do ar, temperatura da folha, radiação fotossintética ativa na câmara e radiação fotossintética ativa fora da câmara, não influem significativamente nos resultados do treinamento.

Isso pode sugerir a razão da formação de três grupos de combinações, nos resultados dos treinamentos das 18 combinações. No primeiro grupo de combinações, que apresenta os maiores erros, não estão presentes as duas variáveis de concentração de $\mathrm{CO}_{2}$, do ar e da câmara. No segundo grupo de combinações, onde o erro é significativamente menor que o do primeiro grupo, estão presentes as duas variáveis de concentração de $\mathrm{CO}_{2}$, do ar e da câmara; mas só uma das variáveis de umidade relativa, do ar ou da câmara. No terceiro grupo de combinações, que apresenta os menores erros, estão presentes as duas variáveis de concentração de $\mathrm{CO}_{2}$, do ar e da câmara, e as duas variáveis de umidade relativa, do ar e da câmara.

Para evidenciar a influência das duas variáveis de concentração de $\mathrm{CO}_{2}$, do ar e da câmara, e das duas variáveis de umidade relativa, do ar e da câmara, foi elaborada a Tabela 5.21. Nessa tabela são mostrados os resultados dos treinamentos, o erro relativo médio das combinações 1, 6 e 11, correspondentes às 4 estações, aos três níveis e aos dois conjuntos de treinamento, com todos os dados e com dados filtrados. Observando os resultados dessas combinações, nota-se claramente a diferença significativa entre elas. Cada uma dessas combinações tem uma 
característica, já analisada. Na combinação 1, está presente só uma das variáveis de concentração de $\mathrm{CO}_{2}$, nesse caso a do ar. Na combinação 6, estão presentes as duas variáveis de concentração de $\mathrm{CO}_{2}$, do ar e da câmara. Na combinação 11 , estão presentes as duas variáveis de concentração de $\mathrm{CO}_{2}$, do ar e da câmara, e as duas variáveis de umidade relativa, do ar e da câmara.

Tabela 5.21 - Influência das variáveis de entrada nos resultados do treinamento.

\begin{tabular}{|c|c|c|c|c|c|c|c|}
\hline \multirow[t]{3}{*}{ Estação } & \multirow{3}{*}{$\begin{array}{l}\text { Combi } \\
\text { nação }\end{array}$} & \multicolumn{6}{|c|}{ Erro relativo médio (\%) } \\
\hline & & \multicolumn{2}{|c|}{ Nível 1} & \multicolumn{2}{|c|}{ Nível 2} & \multicolumn{2}{|c|}{ Nível 3} \\
\hline & & $\begin{array}{l}\text { Todos } \\
\text { os dados }\end{array}$ & \begin{tabular}{|l|} 
Dados \\
filtrados
\end{tabular} & $\begin{array}{l}\text { Todos } \\
\text { os dados }\end{array}$ & $\begin{array}{l}\text { Dados } \\
\text { filtrados }\end{array}$ & $\begin{array}{l}\text { Todos } \\
\text { os dados }\end{array}$ & $\begin{array}{l}\text { Dados } \\
\text { filtrados }\end{array}$ \\
\hline \multirow[t]{3}{*}{ Outono } & 1 & 124.6 & 67.4 & 91.1 & 58.8 & 85.2 & 52.3 \\
\hline & 6 & 32.4 & 14.5 & 39.6 & 25.8 & 33.5 & 18.9 \\
\hline & 11 & 20.4 & 9.9 & 23.1 & 11.7 & 24.5 & 11.5 \\
\hline \multirow[t]{3}{*}{ Inverno } & 1 & 77.2 & 42.1 & 82.3 & 40.9 & 119.6 & 36.4 \\
\hline & 6 & 30.6 & 15.4 & 39.0 & 17.8 & 57.5 & 14.5 \\
\hline & 11 & 13.2 & 7.3 & 17.9 & 6.3 & 20.6 & 6.4 \\
\hline \multirow[t]{3}{*}{ Primavera } & 1 & 122.1 & 46.9 & 133.8 & 42.9 & 119.6 & 43.4 \\
\hline & 6 & 50.8 & 20.0 & 50.6 & 18.9 & 148.3 & 19.2 \\
\hline & 11 & 19.6 & 7.4 & 35.5 & 7.5 & 21.3 & 5.9 \\
\hline \multirow[t]{3}{*}{ Verão } & 1 & 140.4 & 60.6 & 265.9 & 57.3 & 129.8 & 34.4 \\
\hline & 6 & 45.4 & 17.3 & 70.9 & 20.6 & 153.7 & 20.6 \\
\hline & 11 & 22.2 & 8.4 & 19.6 & 7.3 & 24.1 & 4.8 \\
\hline
\end{tabular}

Neste trabalho de pesquisa, uma das combinações desejadas para modelar fotossíntese, que foi proposta a principio, foi a combinação 1, porque se pretendia modelar fotossíntese com as variáveis ambientais medidas no ar, fora da câmara; exceto PARi, que é a radiação que chega justo na folha que está sendo medida. Os resultados apresentados mostram que com a combinação 1 não se obtêm bons resultados. 


\section{b) Resultados do primeiro e segundo conjunto de treinamento}

No item 5.2.1.1, considerações iniciais, indicou-se que foram realizados dois conjuntos de treinamentos. O primeiro conjunto de treinamento foi realizado com todos os dados, e o segundo conjunto de treinamento foi realizado com dados filtrados (sem os dados na faixa de $-0,099$ a $0,099 \mu \mathrm{mol} \mathrm{CO}_{2} \cdot \mathrm{m}^{-2} \cdot \mathrm{s}^{-1}$ ). Os resultados desses treinamento são apresentados na Figura 5.19 e na Figura 5.20. Nessas figuras são mostrados gráficos do erro relativo médio do treinamento, com todos os dados e com dados filtrados, em função das 18 combinações de variáveis de entrada. $\mathrm{Na}$ Figura 5.19 são apresentados os resultados correspondentes às estações do outono e do inverno, níveis 1, 2 e 3. Na Figura 5.20 são mostrados os resultados das estações da primavera e do verão, níveis 1,2 e 3.

Observando os gráficos dessas figuras, nota-se claramente que obtiveram-se melhores resultados com o segundo conjunto, treinamento com dados filtrados, nas 4 estações, nos 3 níveis, e nas 18 combinações de variáveis de entrada. O erro relativo médio dos treinamentos, com todos os dados, é significativamente maior que o erro relativo médio dos treinamentos, com dados filtrados.

Nos gráficos da Figura 5.19 e da Figura 5.20, também pode ser observado que, nos resultados dos treinamentos das 18 combinações, formam-se três grupos de combinações.

Para facilitar a análise dos resultados do treinamento, com todos os dados e com dados filtrados, foi elaborada a Tabela 5.22, a partir dos dados das tabelas A.1 a A.16, do apêndice A, e da Figura 5.19 e da Figura 5.20. Nessa tabela é mostrado o erro relativo médio dos treinamentos, com todos os dados e com dados filtrados, e a porcentagem da diminuição do erro, das 4 estações e dos três níveis, por grupo de combinações. O erro relativo médio, apresentado na tabela, é a média dos erros relativos médios do grupo de combinações. A porcentagem da diminuição do erro indica em que porcentagem diminuiu o erro, do treinamento com todos os dados para o treinamento com dados filtrados. 
Erro Relativo Médio (Outono, Nível 1)

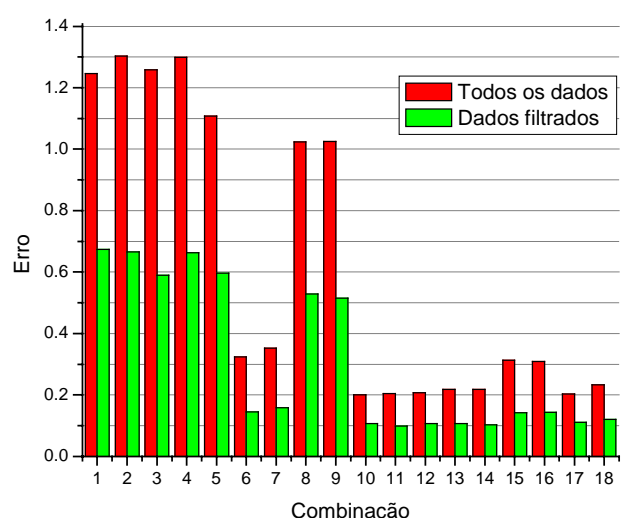

Erro Relativo Médio (Outono, Nível 2)

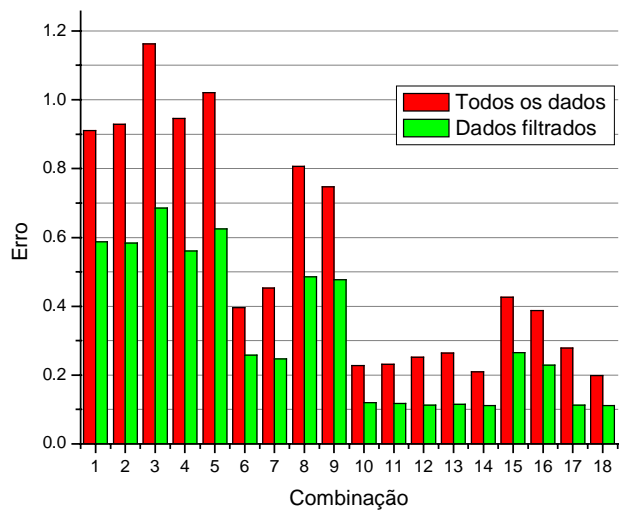

Erro Relativo Médio (Outono, Nível 3)

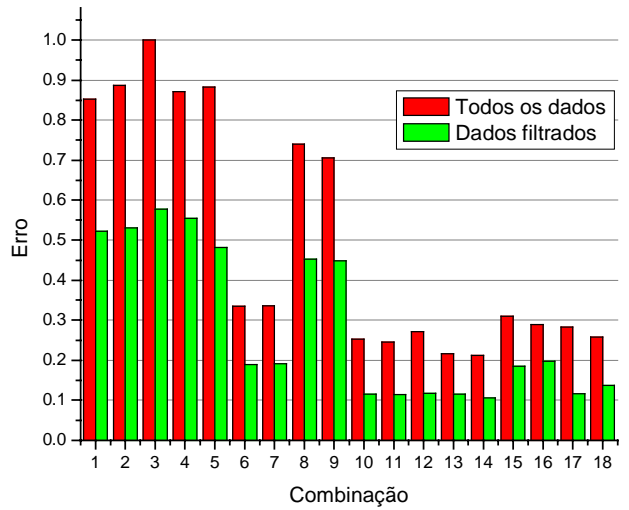

Erro Relativo Médio (Inverno, Nível 1)

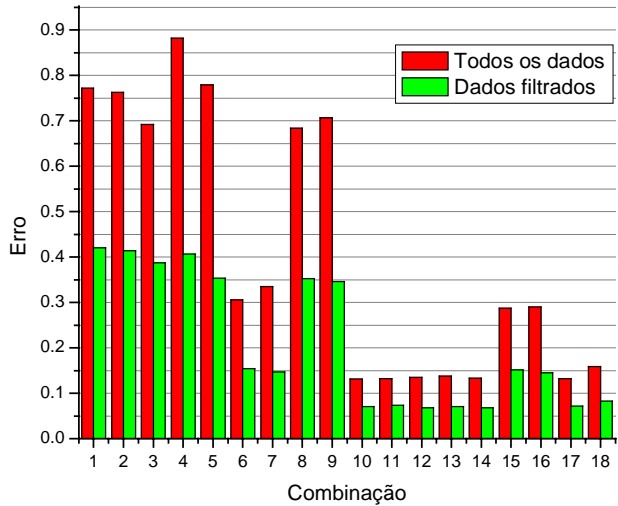

Erro Relativo Médio (Inverno, Nível 2)

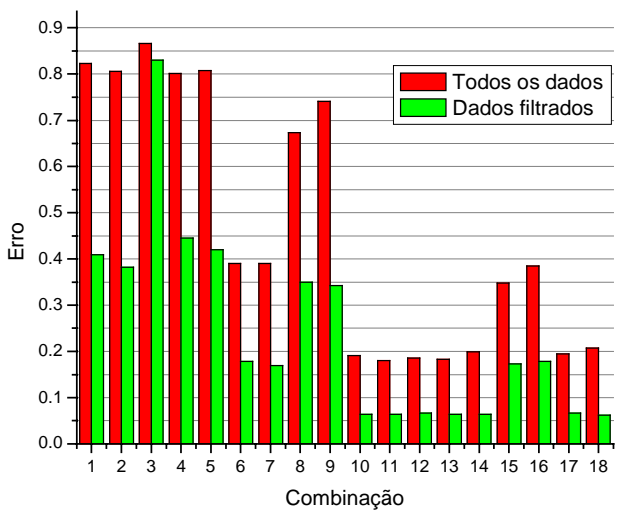

Erro Relativo Médio (Inverno, Nível 3)

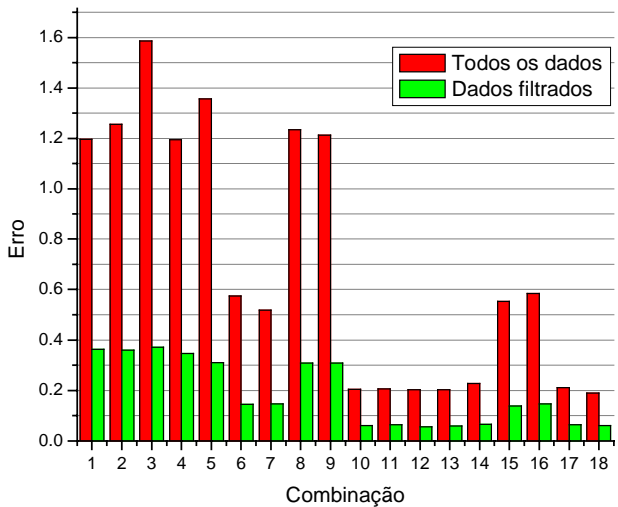

Figura 5.19 Resultados do primeiro e segundo conjunto de treinamento, para as estações do outono e do inverno. 
Erro Relativo Médio (Primavera, Nível 1)

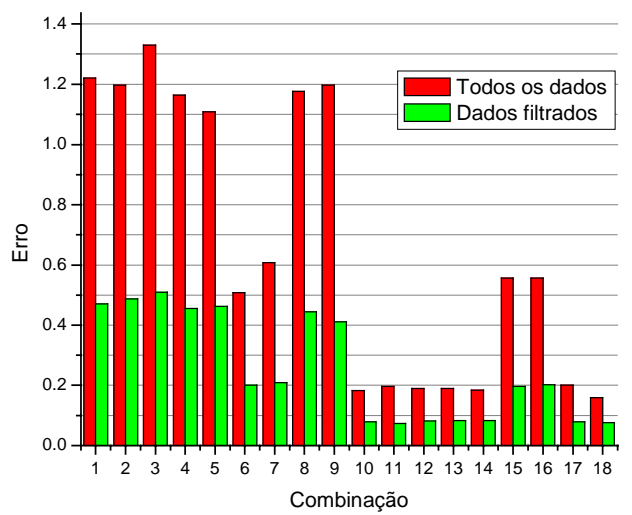

Erro Relativo Médio (Primavera, Nível 2)

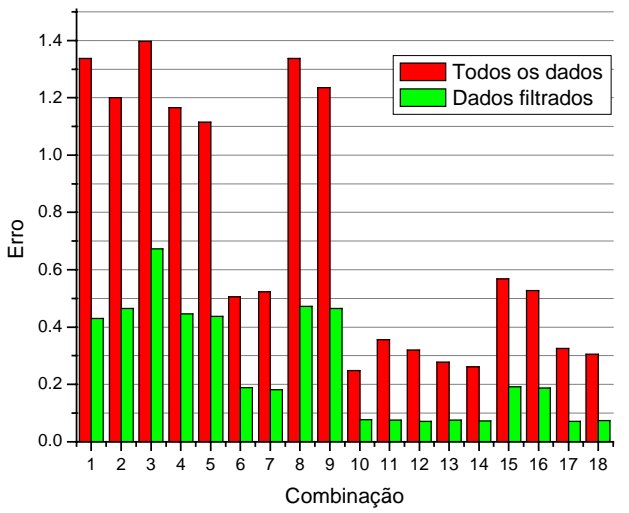

Erro Relativo Médio (Primavera, Nível 3)

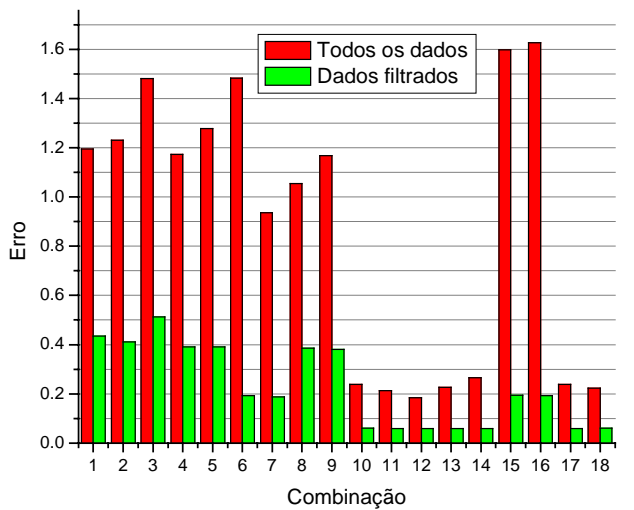

Erro Relativo Médio (Verão, Nível 1)

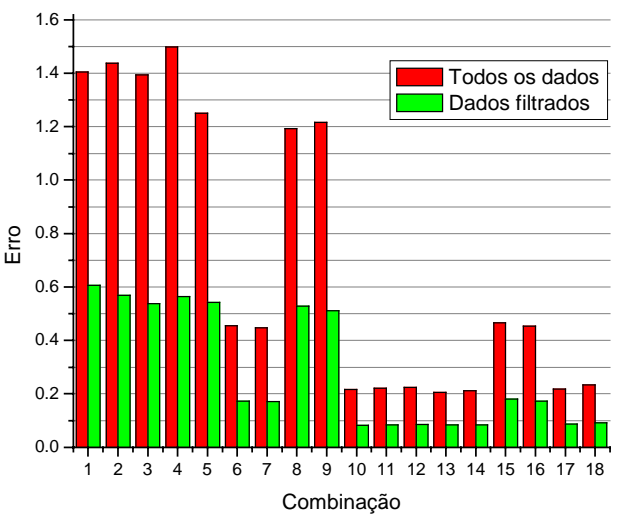

Erro Relativo Médio (Verão, Nível 2)

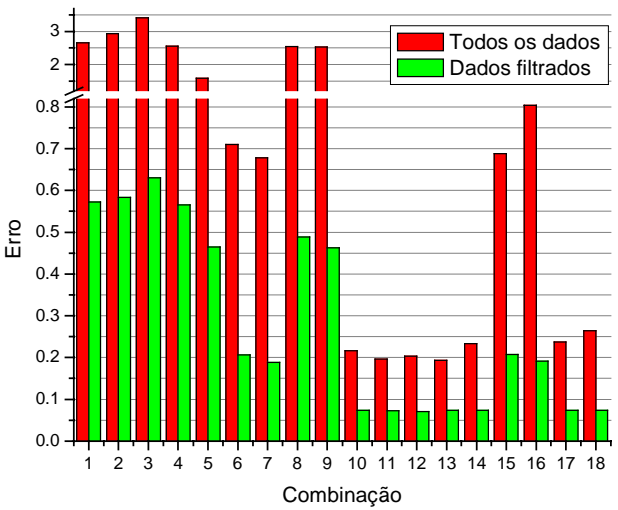

Erro Relativo Médio (Verão, Nível 3)

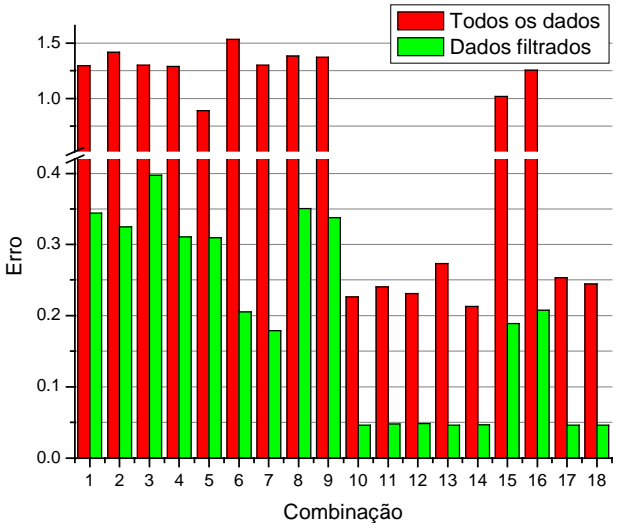

Figura 5.20 Resultados do primeiro e segundo conjunto de treinamento, para as estações da primavera e do verão. 
Tabela 5.22 - Comparação dos resultados do treinamento, com todos os dados e com dados filtrados.

\begin{tabular}{|c|c|c|c|c|c|c|c|c|c|c|}
\hline \multirow[t]{3}{*}{ Estação } & \multirow[t]{3}{*}{ Nível } & \multicolumn{3}{|c|}{$1^{\circ}$ grupo de Comb. } & \multicolumn{3}{|c|}{$2^{\circ}$ grupo de Comb. } & \multicolumn{3}{|c|}{$3^{\circ}$ grupo de Comb. } \\
\hline & & \multicolumn{2}{|c|}{$\begin{array}{l}\text { Erro relativo } \\
\text { médio }\end{array}$} & \multirow[t]{2}{*}{$\overline{\mathrm{DE}}$} & \multicolumn{2}{|c|}{$\begin{array}{l}\text { Erro relativo } \\
\text { médio }\end{array}$} & \multirow[t]{2}{*}{$\overline{\mathrm{DE}}$} & \multicolumn{2}{|c|}{$\begin{array}{l}\text { Erro relativo } \\
\text { médio }\end{array}$} & \multirow[t]{2}{*}{$\mathrm{DE}$} \\
\hline & & TD & DF & & TD & $\mathrm{DF}$ & & TD & DF & \\
\hline \multirow[t]{3}{*}{ Outono } & 1 & $118 \%$ & $60 \%$ & $49 \%$ & $32 \%$ & $14 \%$ & $56 \%$ & $22 \%$ & $11 \%$ & $50 \%$ \\
\hline & 2 & $93 \%$ & $57 \%$ & $39 \%$ & $42 \%$ & $25 \%$ & $40 \%$ & $24 \%$ & $11 \%$ & $54 \%$ \\
\hline & 3 & $85 \%$ & $51 \%$ & $40 \%$ & $32 \%$ & $19 \%$ & $41 \%$ & $25 \%$ & $12 \%$ & $52 \%$ \\
\hline \multirow[t]{3}{*}{ Inverno } & 1 & $75 \%$ & $38 \%$ & $49 \%$ & $30 \%$ & $15 \%$ & $50 \%$ & $14 \%$ & $7 \%$ & $50 \%$ \\
\hline & 2 & $79 \%$ & $45 \%$ & $43 \%$ & $38 \%$ & $17 \%$ & $55 \%$ & $19 \%$ & $6 \%$ & $68 \%$ \\
\hline & 3 & $129 \%$ & $34 \%$ & $74 \%$ & $56 \%$ & $14 \%$ & $75 \%$ & $21 \%$ & $6 \%$ & $71 \%$ \\
\hline \multirow[t]{3}{*}{ Primavera } & 1 & $120 \%$ & $46 \%$ & $62 \%$ & $56 \%$ & $20 \%$ & $64 \%$ & $19 \%$ & $8 \%$ & $58 \%$ \\
\hline & 2 & $126 \%$ & $48 \%$ & $62 \%$ & $53 \%$ & $19 \%$ & $64 \%$ & $30 \%$ & $7 \%$ & $77 \%$ \\
\hline & 3 & $123 \%$ & $42 \%$ & $66 \%$ & $141 \%$ & $19 \%$ & $87 \%$ & $23 \%$ & $6 \%$ & $74 \%$ \\
\hline \multirow[t]{3}{*}{ Verão } & 1 & $134 \%$ & $55 \%$ & $59 \%$ & $46 \%$ & $17 \%$ & $63 \%$ & $22 \%$ & $9 \%$ & $59 \%$ \\
\hline & 2 & $260 \%$ & $54 \%$ & $79 \%$ & $72 \%$ & $20 \%$ & $72 \%$ & $22 \%$ & $7 \%$ & $68 \%$ \\
\hline & 3 & $128 \%$ & $34 \%$ & $73 \%$ & $128 \%$ & $20 \%$ & $84 \%$ & $24 \%$ & $5 \%$ & $79 \%$ \\
\hline
\end{tabular}

TD: Todos os dados, DF: Dados filtrados, DE: Diminuição do erro

Observando os resultados da Tabela 5.22, nota-se claramente a diferença que houve entre os resultados dos treinamentos com todos os dados e com dados filtrados. O erro diminui significativamente com o segundo conjunto de treinamento. Nos resultados do primeiro grupo de combinações, na estação do outono, níveis 1, 2 e 3, e na estação do inverno, níveis 1 e 2, o erro diminui entre 39 e 49\%; nas estações, da primavera e do verão, níveis 1, 2 e 3; e na estação do inverno, nível 3, o erro diminui na faixa de 59 a $79 \%$. Nos resultados do segundo grupo de combinações, no outono, nos três níveis, e no inverno, níveis 1 e 2 , o erro diminui entre 40 e 56\%; na primavera e no verão, nos três níveis, e no nível 3 do inverno, o erro diminui na faixa de 63 a 87\%. Nos resultados de terceiro grupo de combinações, nos três níveis do outono, e no nível 1 do inverno, o erro diminui entre 50 a 54\%; na primavera e no verão, nos três níveis, e no inverno, níveis 2 e 3, o erro diminui na 
faixa de 58 a 79\%. Por conseguinte, esses resultados indicam que houve uma influência significativa dos valores de fotossíntese medidos na faixa de $-0,099$ a $0,099 \mu \mathrm{mol} \mathrm{CO}_{2} \cdot \mathrm{m}^{-2} \cdot \mathrm{s}^{-1}$, nos resultados dos treinamentos, nas 4 estações e nos três níveis. Essa influência foi maior, na primavera e no verão, nos três níveis, e no nível 3 do inverno.

Portanto, os resultados apresentados na Figura 5.19, na Figura 5.20 e na Tabela 5.22 corroboram as observações realizadas no item 5.2.1.1, considerações iniciais, sobre como os valores de fotossíntese, medidos na faixa de -0.099 a 0,099 $\mu \mathrm{mol} \mathrm{CO} 2 \cdot \mathrm{m}^{-2} \cdot \mathrm{s}^{-1}$, relacionados com a calibração do medidor de fotossíntese, influem consideravelmente nos resultados dos treinamentos.

\section{c) Resultados por estação e por nível}

Neste item serão analisados os resultados por estação e por nível na planta. Isto é, que estações e que níveis apresentaram os melhores resultados nos treinamentos. Primeiro analisaram-se os resultados por estações e, em seguida, por níveis.

Para analisar os resultados por estações, na Figura 5.21 e na Figura 5.22 são apresentados os resultados dos treinamentos, gráficos do erro relativo médio, das 4 estações, e dos três níveis. Na Figura 5.21 são mostrados os resultados do primeiro conjunto, treinamento com todos os dados, e na Figura 5.22 os resultados do segundo conjunto, treinamento com dados filtrados. Nos gráficos dessas figuras observa-se, também, a formação dos três grupos de combinações, exceto no gráfico do nível 3, da Figura 5.21, primeiro conjunto de treinamento. 
Erro Relativo Médio (Nível 1)

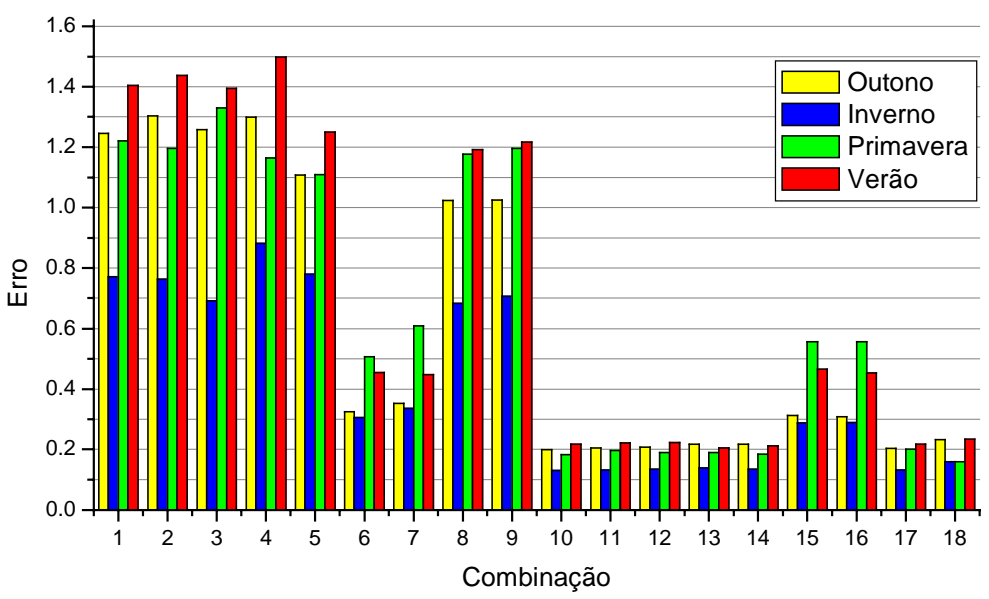

Erro Relativo Médio (Nível 2)

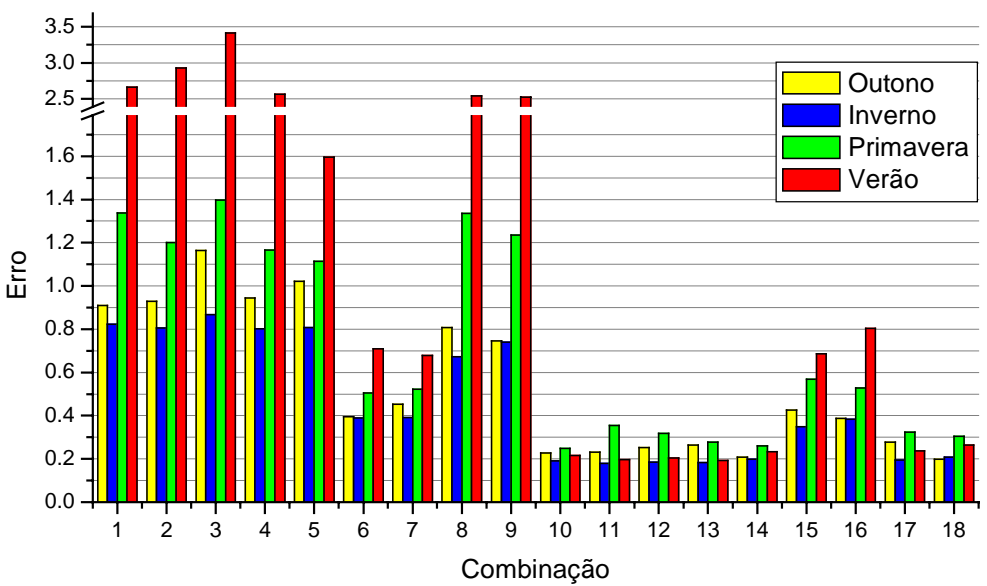

Erro Relativo Médio (Nível 3)

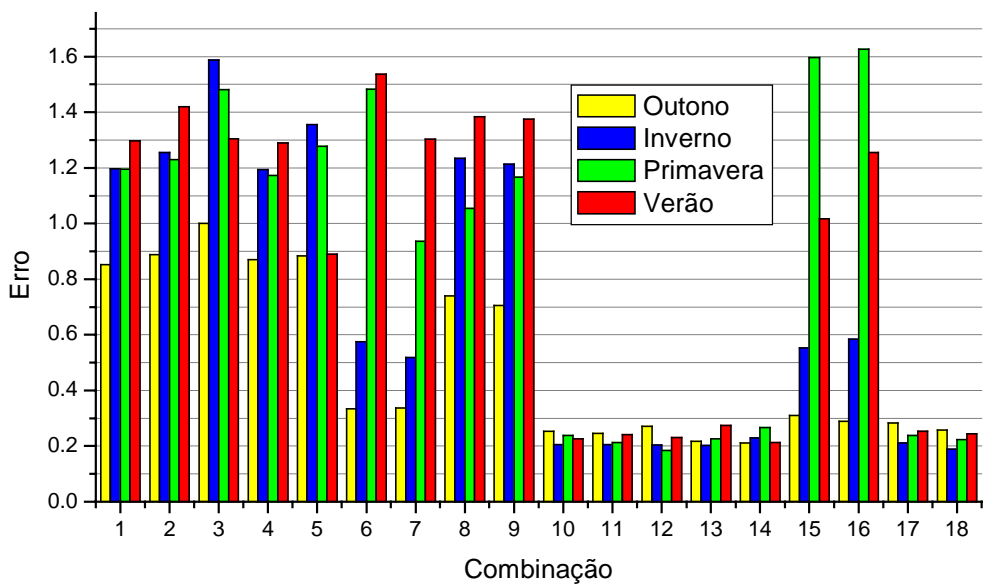

Figura 5.21 Resultados dos treinamentos, das 4 estações, do primeiro conjunto. 
Erro Relativo Médio (Nível 1)

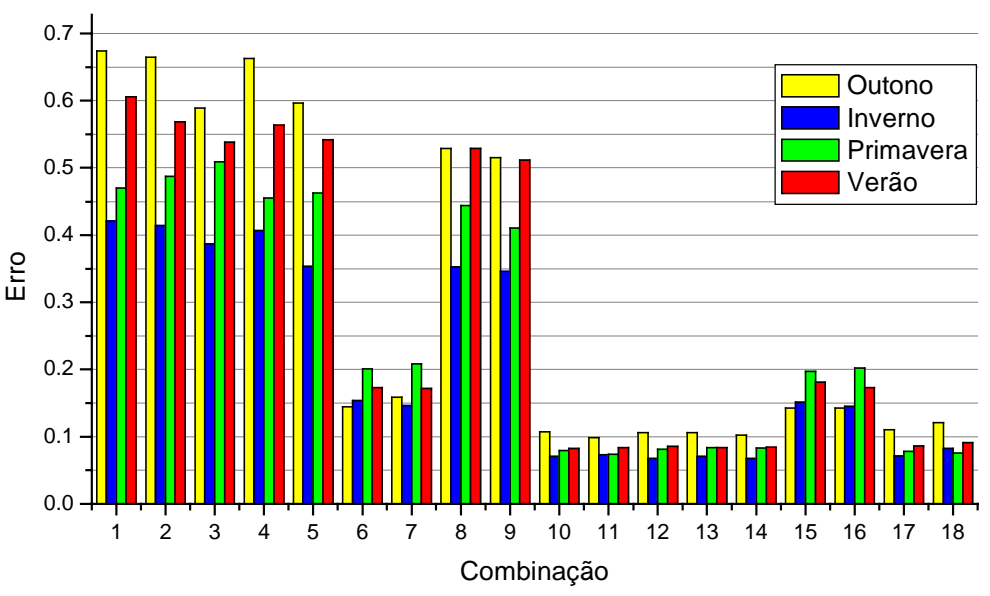

Erro Relativo Médio (Nível 2)

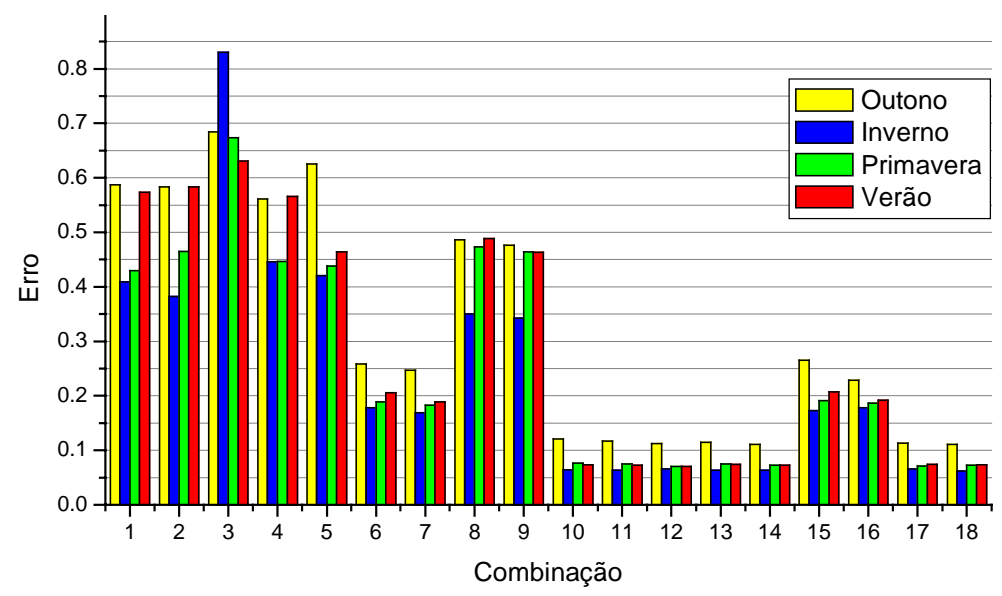

Erro Relativo Médio (Nível 3)

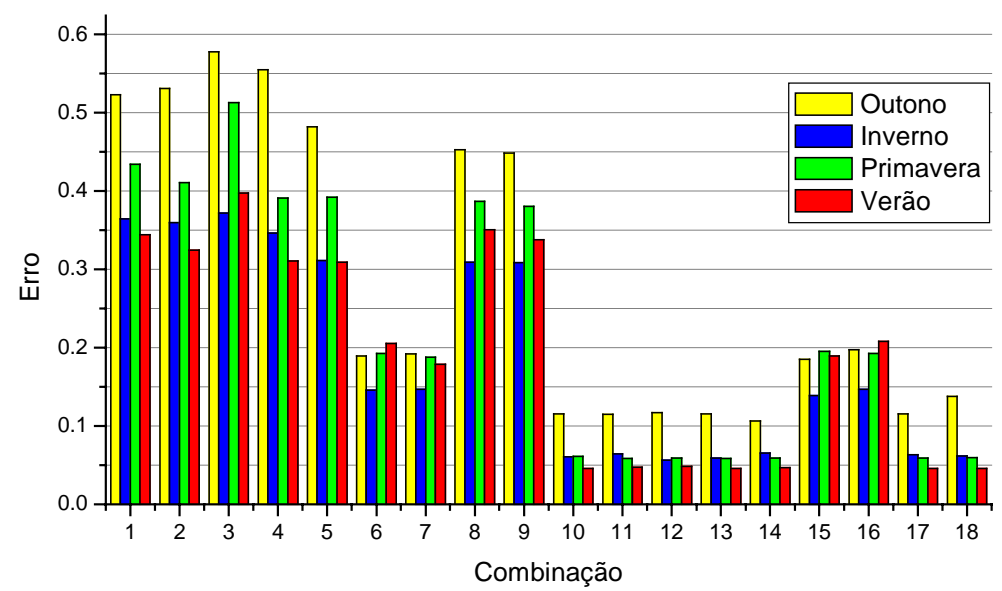

Figura 5.22 Resultados dos treinamentos, das 4 estações, do segundo conjunto. 
No primeiro conjunto, treinamento com todos os dados, observando os gráficos da Figura 5.21, nota-se que a estação do verão apresenta os maiores erros no nível 1, primeiro grupo de combinações; e no nível 2, primeiro e segundo grupo de combinações. No nível 2, os erros foram significativamente maiores. A estação da primavera apresenta os maiores erros no nível 1, no segundo grupo de combinações; no nível 2, no terceiro grupo de combinações; e no nível 3, nas combinações 15 e 16. A estação do inverno mostra os menores erros nos níveis 1 e 2 , nos três grupos de combinações; e no nível 3, no terceiro grupo de combinações. A estação do outono apresenta os menores erros no nível 3, no primeiro e segundo grupo de combinações; e os maiores erros no terceiro grupo de combinações, exceto nas combinações 13 e 14. Em resumo, os melhores resultados foram apresentados pelas estações do inverno e do outono. Pelo inverno, nos níveis 1 e 2, nos três grupos de combinações; e no nível 3, no terceiro grupo de combinações. Pelo outono, no nível 3, no primeiro e segundo grupo de combinações.

No segundo conjunto, treinamento com dados filtrados, Figura 5.22, a estação do outono apresenta os maiores erros no nível 1, no primeiro e terceiro grupo de combinações; e nos níveis 2 e 3, nos três grupos de combinações, exceto na combinação 3 do nível 2. A estação do inverno apresenta os menores erros nos níveis 1 e 2, nos três grupos de combinações, exceto na combinação 3 do nível 2. A estação do verão apresenta os menores erros no nível 3, no primeiro e terceiro grupo de combinações. A estação da primavera mostra os maiores erros no nível 1, no segundo grupo de combinações. Em geral, os melhores resultados foram apresentados pelas estações do inverno e do verão. Pelo inverno, nos níveis 1 e 2, nos três grupos de combinações; e no nível 3, no segundo grupo de combinações. Pela estação do verão, no nível 3, no primeiro e no terceiro grupo de combinações.

Comparando os resultados do primeiro e segundo conjunto de treinamento, nota-se que os maiores erros apresentados, no primeiro conjunto, pelas estações do verão e da primavera, foram devido ao erro de calibração do medidor de fotossíntese portátil, valores medidos na faixa de $-0,099$ a $0,099 \mu \mathrm{mol} \mathrm{CO}_{2} \cdot \mathrm{m}^{-2} \cdot \mathrm{s}^{-1}$. Observando os resultados dessas estações, no segundo conjunto, nota-se que, na maioria dos casos, 
apresentam erros menores que a estação do outono; mas, maiores que a estação do inverno.

Para analisar os resultados por níveis, serão utilizadas a Figura 5.17 e a Figura 5.18, apresentadas no item a, influência das combinações de variáveis de entrada. Nessas figuras são mostrados os resultados dos treinamentos, gráficos do erro relativo médio, dos três níveis, para cada estação. A Figura 5.17, apresenta os resultados do primeiro conjunto, e a Figura 5.18 os resultados do segundo conjunto.

Observando os resultados do primeiro conjunto, Figura 5.17, nota-se que o nível 1 apresenta erros significativamente maiores na estação do outono, no primeiro grupo de combinações. O nível 2 mostra erros apreciavelmente maiores na estação do verão, no primeiro grupo de combinações. Mostra, também, erros maiores na estação do outono, no segundo grupo de combinações; e na primavera, no terceiro grupo de combinações. O nível 3 apresenta erros significativamente maiores na estação do inverno, no primeiro e segundo grupo de combinações; e na primavera e no verão, no segundo grupo de combinações. Em geral, os três níveis mostram erros significativamente maiores no primeiro grupo de combinações, só que cada um em uma estação diferente. O nível 3 apresenta erros apreciavelmente maiores no segundo grupo de combinações, nas estações do inverno, da primavera e do verão. Os três níveis mostram um comportamento similar no terceiro grupo de combinações, nas estações do outono, do inverno e do verão, exceto na estação da primavera, onde o nível 2 apresenta os maiores erros.

No segundo conjunto, treinamento com dados filtrados, observando os gráficos da Figura 5.18, nota-se que o nível 3 apresenta os menores erros no primeiro grupo de combinações, nas 4 estações; e no terceiro grupo de combinações, nas estações da primavera e do verão. O nível 1 mostra menores erros no segundo grupo de combinações, nas estações do outono e do verão. Em resumo, os três níveis apresentam um comportamento similar, nas estações do outono, do inverno e da primavera, não existindo diferenças significativas entre os erros dos níveis, exceto na combinação 3, onde o nível 2 mostra erros apreciavelmente maiores. Os níveis 1 e 2 
mostram erros significativamente maiores no primeiro e no terceiro grupo de combinações, na estação do verão.

Comparando os resultados do primeiro e do segundo conjunto de treinamento, nota-se que, no primeiro conjunto de treinamento, os erros significativamente maiores apresentados pelos três níveis, cada um em uma diferente estação, e em uma diferente combinação, são devidos ao erro de calibração do medidor de fotossíntese portátil. Esses erros desaparecem ao filtrar os dados, na faixa de -0,099 a 0,099 $\mu$ mol $\mathrm{CO}_{2} \cdot \mathrm{m}^{-2} \cdot \mathrm{s}^{-1}$, como pode ser observado nos resultados do segundo conjunto de treinamento. No segundo conjunto, não se observa diferença de erros significativa entre os níveis. Exceções são a combinação 3, nas estações do inverno e da primavera, onde o nível 2 mostra erros significativamente maiores; e o primeiro e o terceiro grupo de combinações, na estação do verão, onde os níveis 1 e 2 apresentam erros significativamente maiores.

\section{d) Teste das ANNs}

No item 4.2.4, teste das ANNs, mencionou-se que as redes treinadas são validadas com dados que não the foram fornecidos durante o treinamento, para assim avaliar sua capacidade de generalização. Neste item serão analisados os resultados do teste das redes neurais treinadas. Primeiro serão analisados os resultados do teste do primeiro conjunto de treinamento, e a seguir os resultados do segundo conjunto.

Na Figura 5.23 e na Figura 5.24 são apresentados os resultados do teste do treinamento das ANNs do primeiro conjunto, treinamento com todos os dados. Nessas figuras são apresentados gráficos do erro relativo médio, do treinamento e do teste, em função das 18 combinações de variáveis de entrada. Na Figura 5.23 são mostrados os resultados correspondentes às estações do outono e do inverno, e na Figura 5.24 os resultados das estações da primavera e do verão. As figuras apresentam os resultados dos três níveis. 

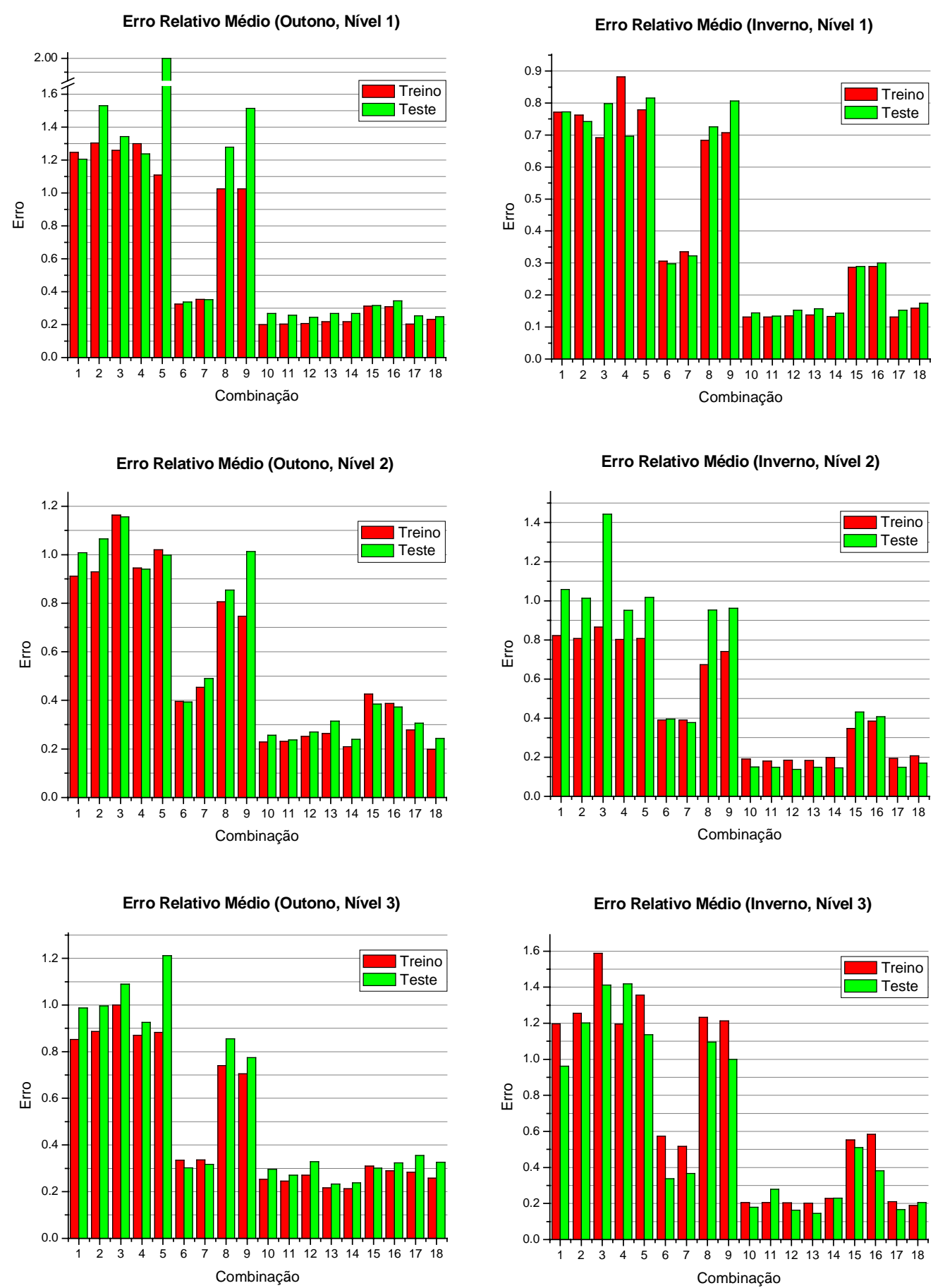

Figura 5.23 Resultados do treino e do teste das ANNs, das estações do outono e do inverno, primeiro conjunto de treinamento (com todos os dados). 
Erro Relativo Médio (Primavera, Nível 1)

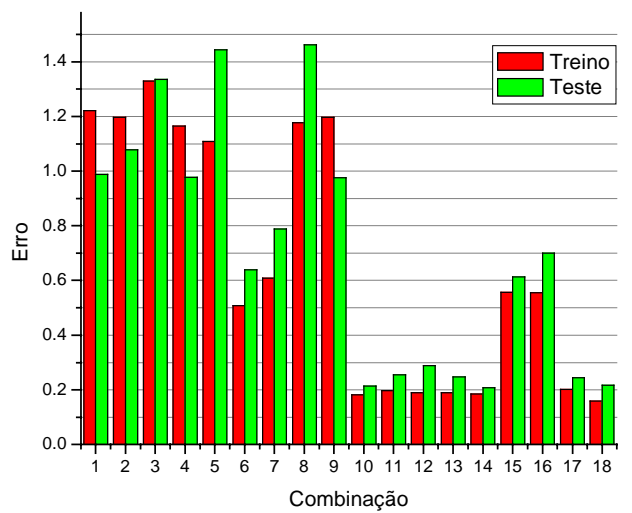

Erro Relativo Médio (Primavera, Nível 2)

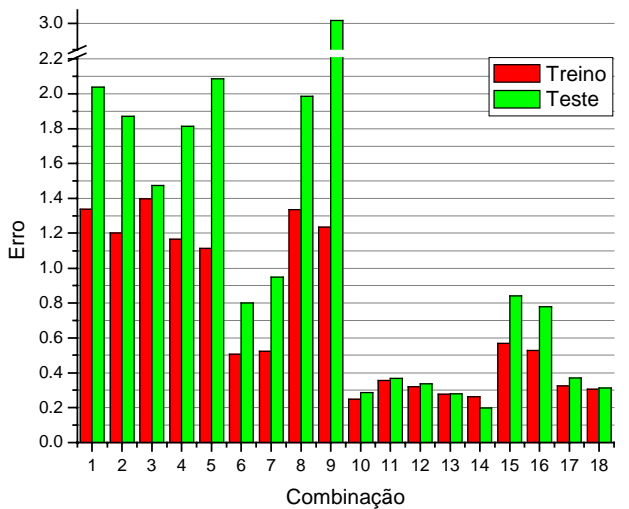

Erro Relativo Médio (Primavera, Nível 3)

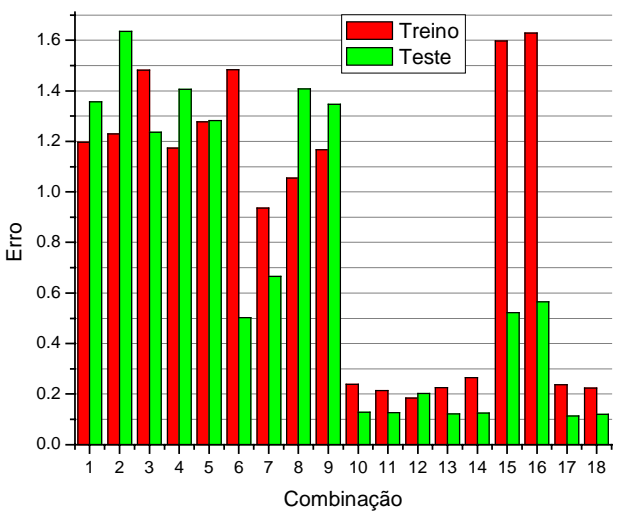

Erro Relativo Médio (Verão, Nível 1)

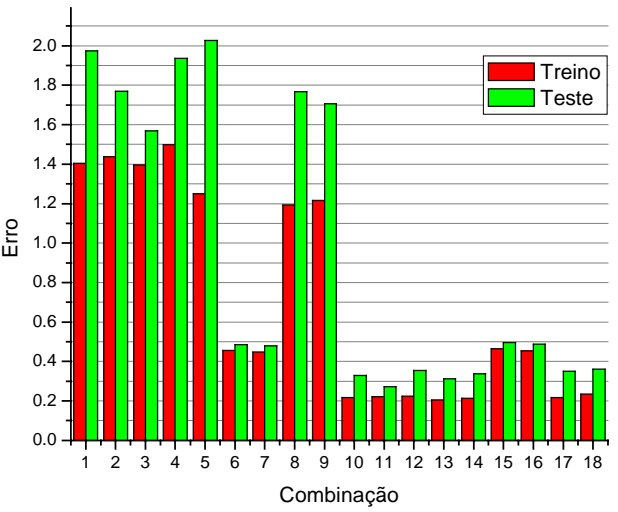

Erro Relativo Médio (Verão, Nível 2)

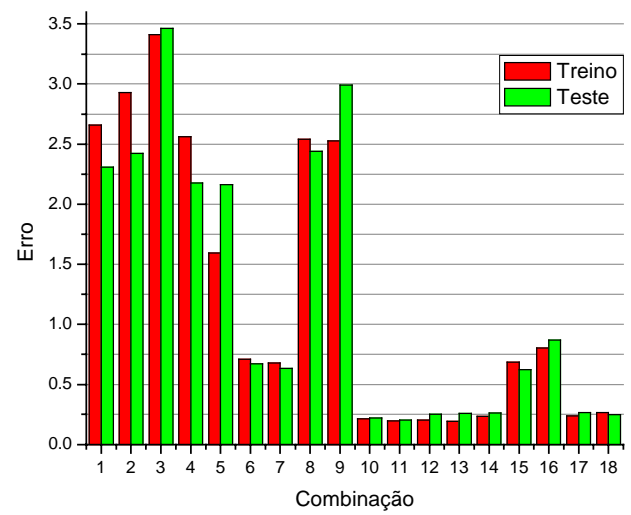

Erro Relativo Médio (Verão, Nível 3)

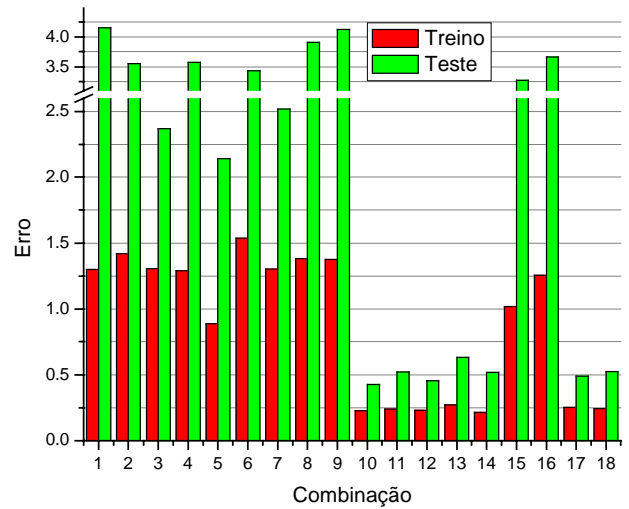

Figura 5.24 Resultados do treino e do teste das ANNs, das estações da primavera e do verão, primeiro conjunto de treinamento (com todos os dados). 
Quando é realizado o teste das ANNs, espera-se que o erro apresentado por este seja maior, porque a rede responde a dados de entrada que não lhe foram fornecidos durante o treinamento. A magnitude da diferença do erro, entre o teste e o treinamento, indica a capacidade de generalização da rede treinada. Quanto menor é a diferença do erro maior é a capacidade de generalização que teve a rede.

Observando os erros do teste e do treinamento, na Figura 5.23 e na Figura 5.24, nota-se que os resultados do teste, na maioria das estações e dos níveis, são bons. Na estação do outono, só as combinações 2, 5, 8 e 9, no nível 1; a combinação 9, no nível 2; e a combinação 5, no nível 3, não apresentam bons resultados. $\mathrm{Na}$ estação do inverno, o teste não mostra bons resultados só no nível 2, no primeiro grupo de combinações. Na primavera, o teste não apresenta bons resultados no nível 1, nas combinações $5,6,7,8,12$ e 16; no nível 2, no primeiro e segundo grupo de combinações; e no nível 3, nas combinações 1, 2, 4, 8 e 9. A estação do verão apresenta os maiores erros do teste no nível 1, no primeiro e terceiro grupo de combinações; no nível 2, nas combinações 5 e 9; e no nível 3, nas 18 combinações.

Para poder apreciar melhor esses resultados, na Figura 5.25 são apresentados gráficos com a diferença de erro, entre o teste e o treinamento (erro do teste - erro do treinamento), dos três níveis, para cada estação. Os gráficos dessa figura corroboram o mencionado no parágrafo anterior. No primeiro grupo de combinações, a maioria dos resultados apresenta diferença de erro significativamente maior, superior a $5 \%$. No segundo grupo de combinações, alguns resultados mostram diferença de erro superior a 5\%, e outros inferior a 5\%. O terceiro grupo de combinações apresenta os melhores resultados, diferença de erro inferior a 5\%, exceto na estação do verão, nos níveis 1 e 3. 


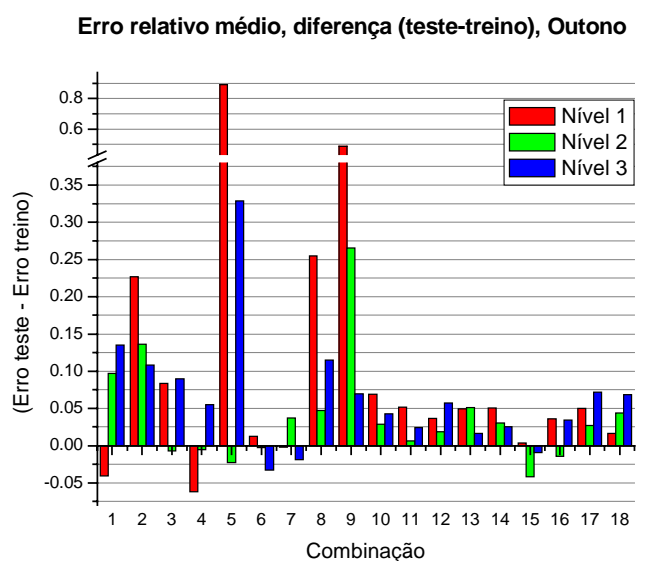

Erro relativo médio, diferença (teste-treino), Primavera

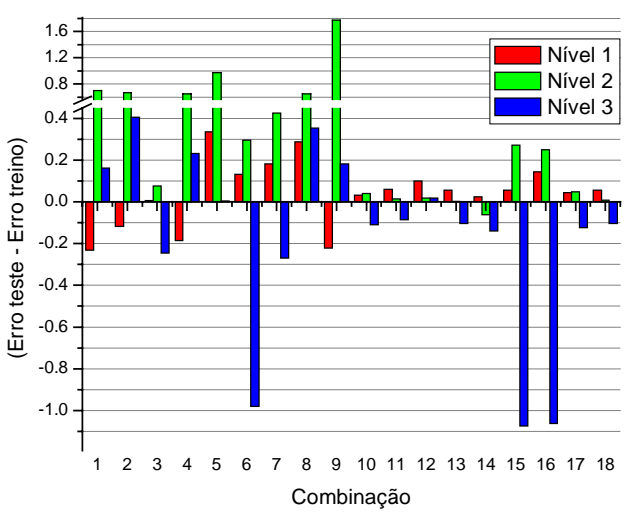

Erro relativo médio, diferença (teste-treino), Inverno

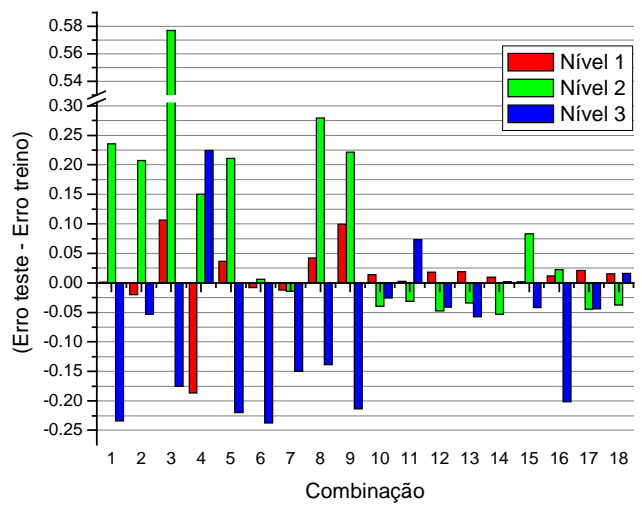

Erro relativo médio, diferença (teste-treino), Verão

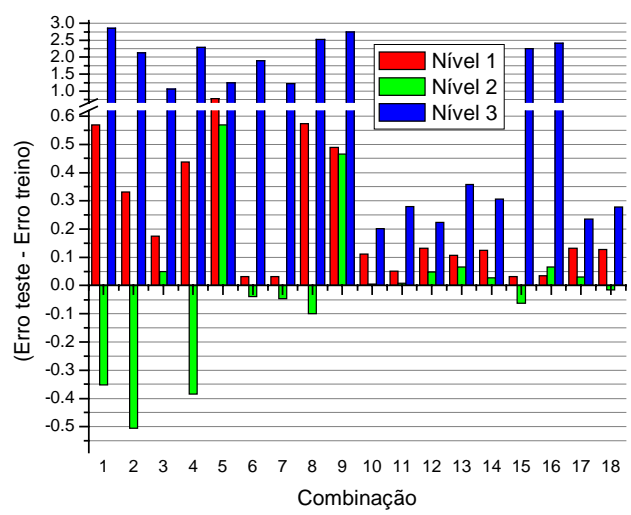

Figura 5.25 Diferença do erro relativo médio, entre o teste e o treino das ANNs, dos 3 níveis, para as 4 estações, primeiro conjunto de treinamento.

Os resultados do teste do segundo conjunto, treinamento com dados filtrados, são mostrados na Figura 5.26, estações do outono e do inverno, e na Figura 5.27, estações da primavera e do verão. Observando os gráficos do erro relativo médio, do treino e do teste, nessas figuras, nota-se que os resultados do teste foram bons, na estação do outono, nos três níveis, nos três grupos de combinações, exceto a combinação 8, do nível 1, e a combinação 5, do nível 2; e nas estações do inverno, da primavera e do verão, no segundo e terceiro grupo de combinações, nos três níveis.

Para observar melhor os resultados do teste do segundo conjunto de treinamento, na Figura 5.28, são mostrados gráficos com a diferença de erro. 
Erro Relativo Médio (Outono, Nível 1)

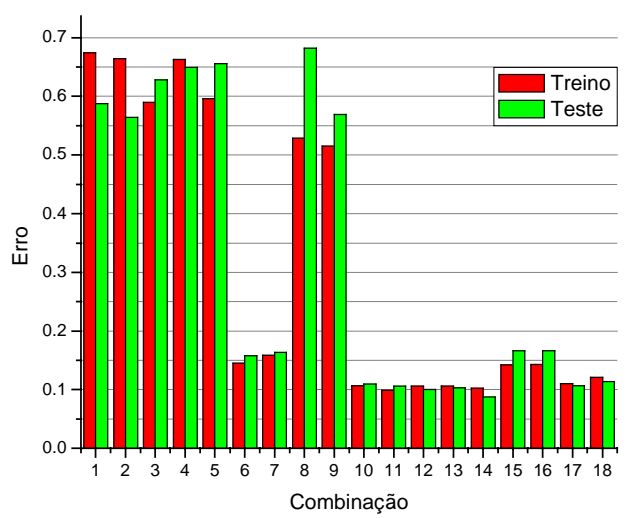

Erro Relativo Médio (Outono, Nível 2)

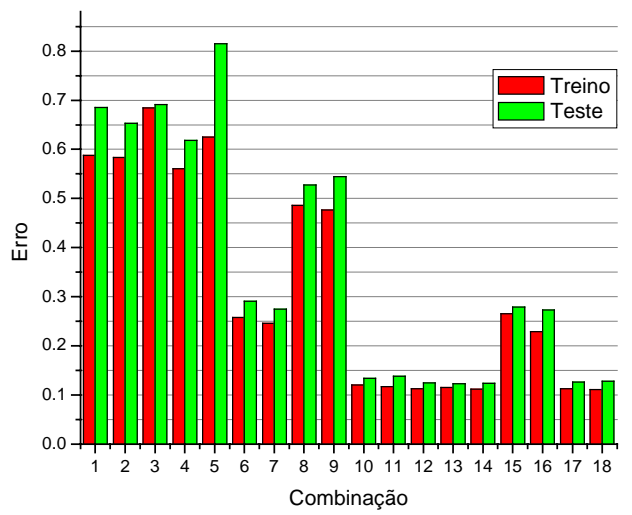

Erro Relativo Médio (Outono, Nível 3)

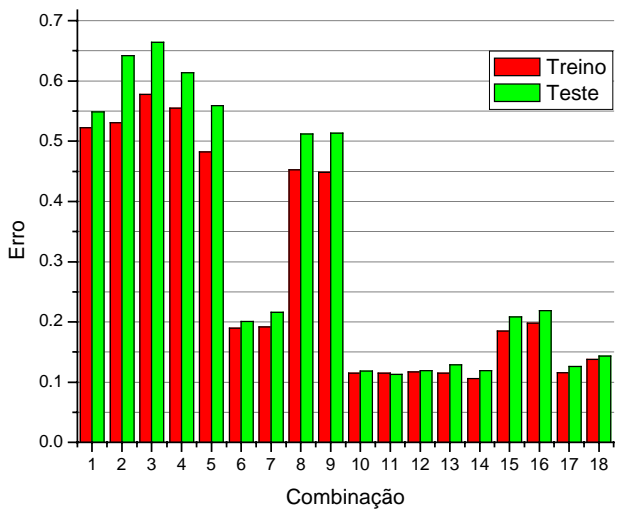

Erro Relativo Médio (Inverno, Nível 1)

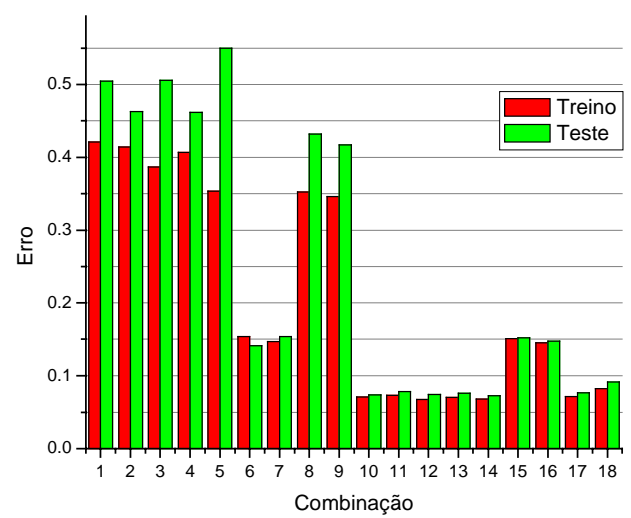

Erro Relativo Médio (Inverno, Nível 2)

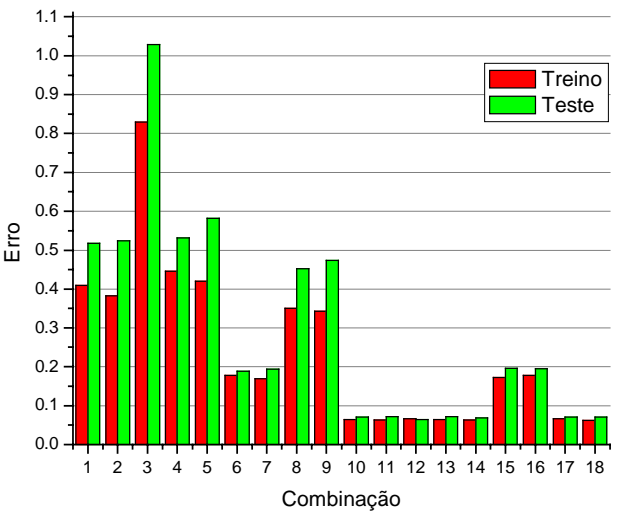

Erro Relativo Médio (Inverno, Nível 3)

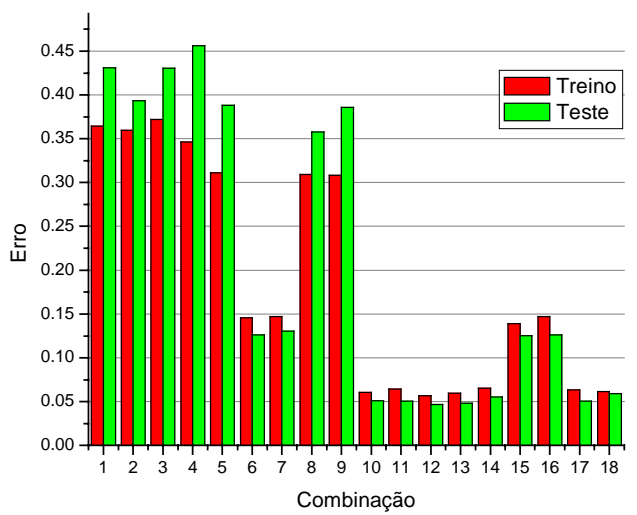

Figura 5.26 Erro relativo médio, do treino e do teste das ANNs, das estações do outono e do inverno, segundo conjunto de treinamento (com dados filtrados). 
Erro Relativo Médio (Primavera, Nível 1)

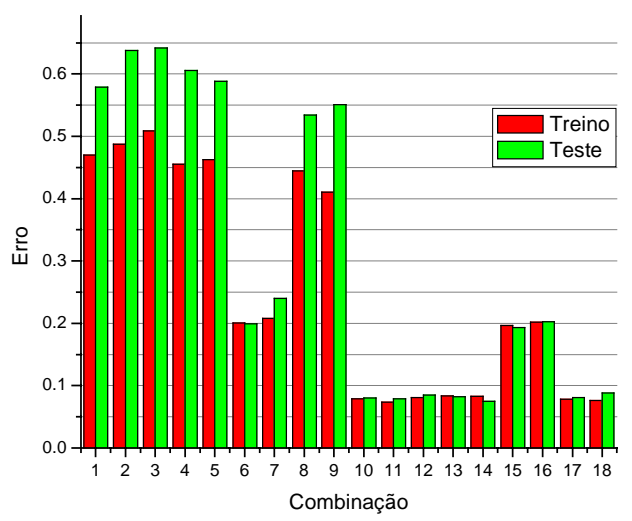

Erro Relativo Médio (Primavera, Nível 2)

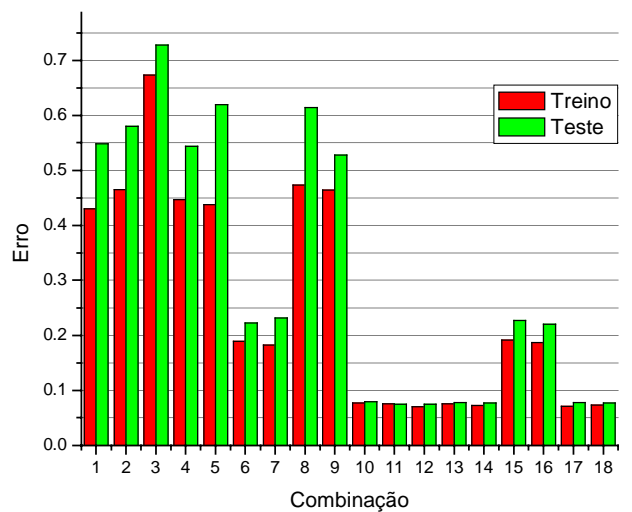

Erro Relativo Médio (Primavera, Nível 3)

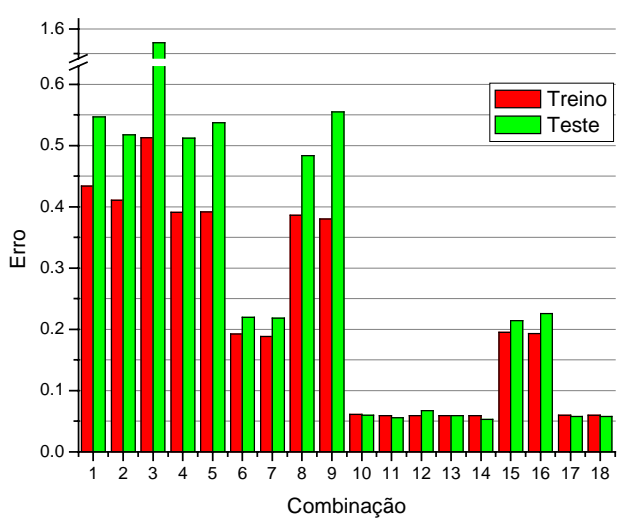

Erro Relativo Médio (Verão, Nível 1)

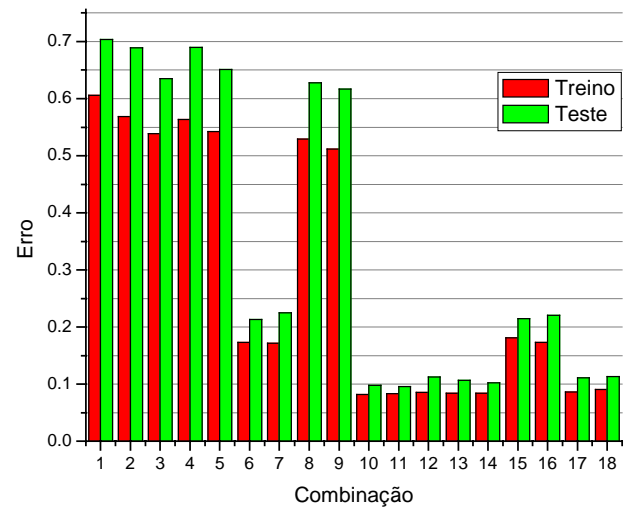

Erro Relativo Médio (Verão, Nível 2)

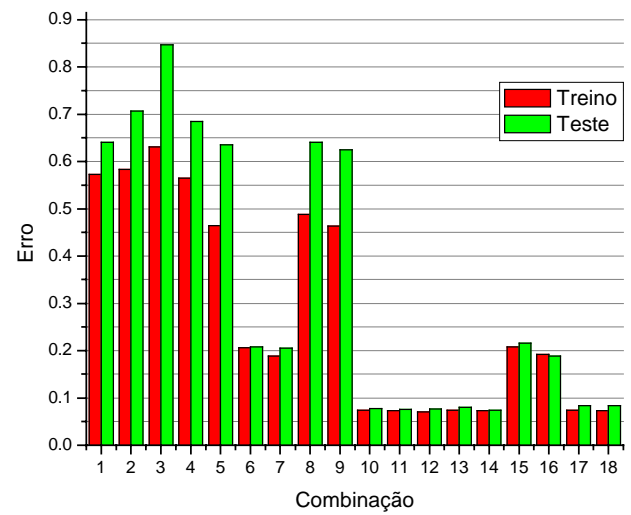

Erro Relativo Médio (Verão, Nível 3)

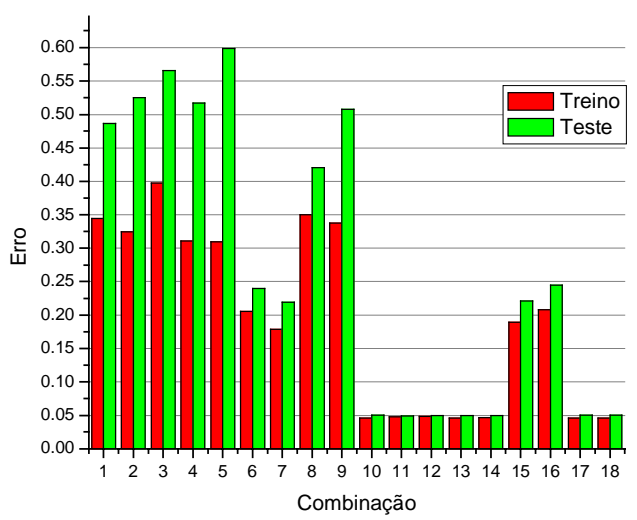

Figura 5.27 Erro relativo médio, do treino e do teste das ANNs, das estações da primavera e do verão, segundo conjunto de treinamento (com dados filtrados). 

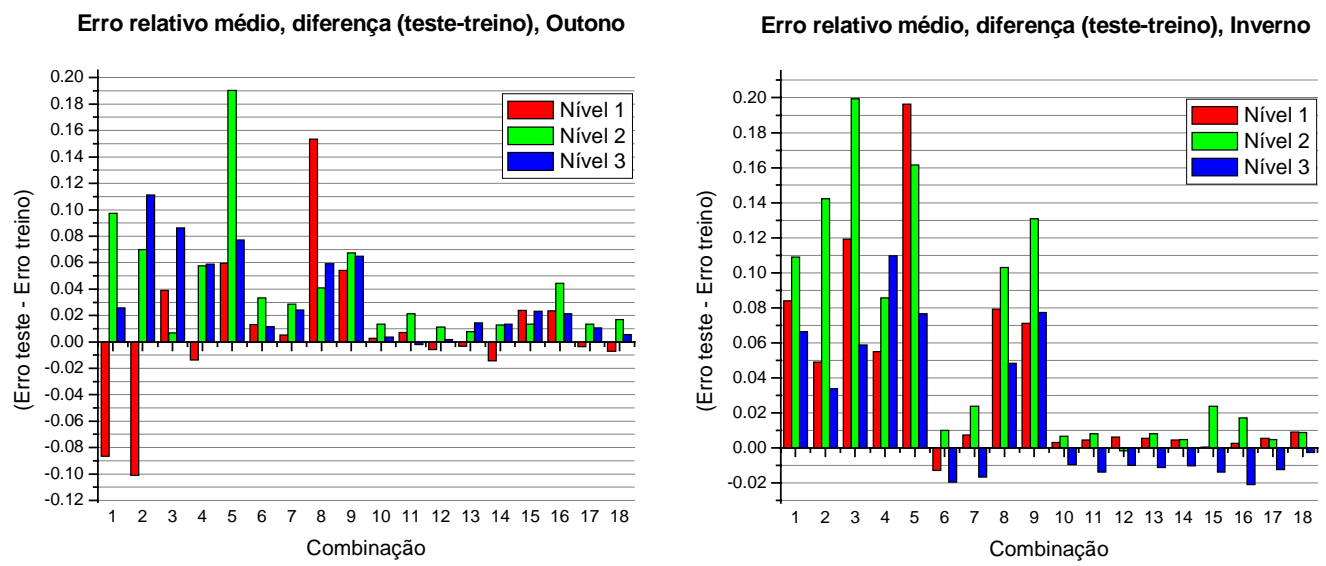

Erro relativo médio, diferença (teste-treino), Primavera

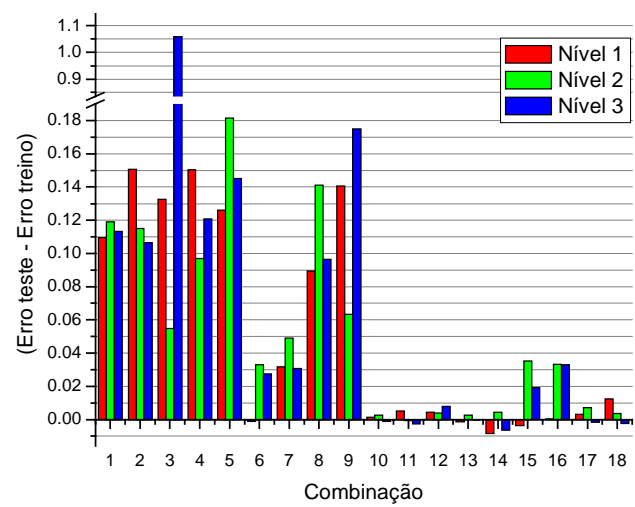

Erro relativo médio, diferença (teste-treino), Verão

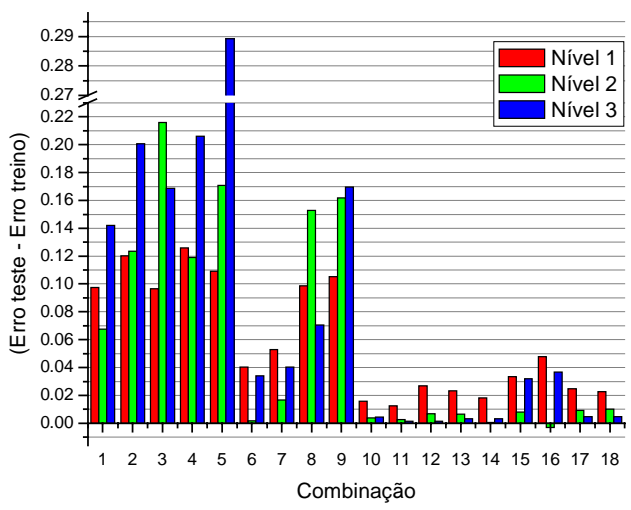

Figura 5.28 Diferença do erro relativo médio, entre o teste e o treino das ANNs, dos 3 níveis, para as 4 estações, segundo conjunto de treinamento.

Observando os gráficos da Figura 5.28, nota-se claramente que as maiores diferenças de erro são apresentadas pelo primeiro grupo de combinações, nas 4 estações. Mesmo assim, nesse grupo, os resultados das estações do outono e do inverno, na maioria de combinações, mostram diferença de erro inferior a 10\%; os resultados das estações da primavera e do verão, na maioria das combinações, apresentam diferença de erro menor que $15 \%$. No segundo grupo de combinações, os resultados são melhores ainda; a diferença de erro é inferior a 4\% nas 4 estações, exceto nas combinações 16 , nível 2, do outono; 7, nível 2, da primavera; e 16, nível 1, do outono, que apresentam diferença de erro inferior a 5\%. O terceiro grupo de combinações mostra os melhores resultados do teste; a diferença do erro é inferior a $1 \%$ nas estações do inverno e da primavera, nos três níveis; na estação do outono, 
nível 1; e na estação do verão, níveis 2 e 3. Nos níveis 2 e 3, do outono, algumas combinações mostram diferença de erro menor que $1 \%$ e outras menor que $2 \%$. No nível 1, do verão, algumas combinações apresentam diferença de erro inferior a $2 \%$ e outras inferior a $3 \%$.

Em resumo, tanto no primeiro conjunto como no segundo conjunto, a maior diferença de erro é apresentada pelo primeiro grupo de combinações, o segundo grupo mostra diferença de erro menor que o primeiro, e o terceiro grupo apresenta os melhores resultados, a menor diferença do erro. Isso é aceitável, pois o primeiro grupo mostrou os maiores erros no treinamento, o segundo grupo apresentou menores erros que o primeiro, e o terceiro grupo mostrou os menores erros no treinamento.

\section{e) Convergência das ANNs}

Como foi mencionado, o treinamento das redes neurais foi realizado com 6000 ou 3000 iterações externas (globais), e tolerância de erro de 0,01 ou 0,001, conforme a Tabela 5.12, a Tabela 5.13 e a Tabela 5.14, quadros dos casos treinados. Os resultados dos treinamentos apresentados, erro relativo médio, desvio padrão e erro relativo máximo, são valores que correspondem à iteração 6000 ou 3000. Isso indica que as redes treinadas não atingiram a tolerância de erro de 0,01 ou 0,001, o que não significa que as redes treinadas não tiveram bom desempenho.

A tolerância de erro é a margem de erro pela qual se determina, durante o treinamento, se o valor de saída calculado pela rede neural é semelhante ao valor de referência (valor medido). Portanto, quando é definido um valor de tolerância pequeno, existiram diferenças pequenas entre o valor de saída calculado pela rede neural e o valor desejado (valor de referência).

Ao realizar os treinamentos, a rede neural trata de convergir para a tolerância definida; nesse processo realiza muitas iterações. A rapidez da convergência depende 
da complexidade do problema. Se o problema não é tão complexo, a rede neural pode convergir antes do número de iterações externas definido. Se o problema é complexo, a rede neural pode não atingir a tolerância de erro indicada, e então realizará iterações até o número de iterações externas definido, tentando atingir a tolerância definida. A rede neural também pode não convergir, porque é definida uma tolerância de erro bem pequena, com o propósito de que a rede neural realize um melhor ajuste, e assim obter melhores resultados.

Para analisar a convergência das redes treinadas, foi escolhida uma combinação que representa cada grupo de combinações: a combinação 1 do primeiro grupo de combinações, a combinação 6 do segundo grupo de combinações, e a combinação 11 do terceiro grupo de combinações. Na Figura 5.29 e na Figura 5.30 são mostrados gráficos da convergência das redes treinadas, das combinações indicadas. Esses gráficos apresentam o erro na saída da rede neural, durante o treinamento, em função do número de iterações, para as 4 estações e para os três níveis. Na Figura 5.29 são mostrados os gráficos da convergência correspondentes ao primeiro conjunto de treinamento, e na Figura 5.30 os gráficos da convergência do segundo conjunto.

Nos gráficos da Figura 5.29, primeiro conjunto, combinações 1, 6 e 11, observa-se uma queda abrupta do erro de treinamento, antes de 1000 iterações, nas 4 estações e nos 3 níveis; exceto na combinação 11, da estação do outono, nível 3, que experimenta duas quedas abruptas, a primeira antes de 1000 iterações, e a segunda antes de 3000 iterações.

No gráfico da combinação 1, Figura 5.29, observa-se que o erro de treinamento começa a permanecer quase constante, para os casos de treinamento com 6000 iterações externas, a partir da iteração 5500; e para os casos de treinamento com 3000 iterações externas, estações da primavera, níveis 1 e 3, e do verão, nível 2, permanece quase constante após de 2200 iterações. 

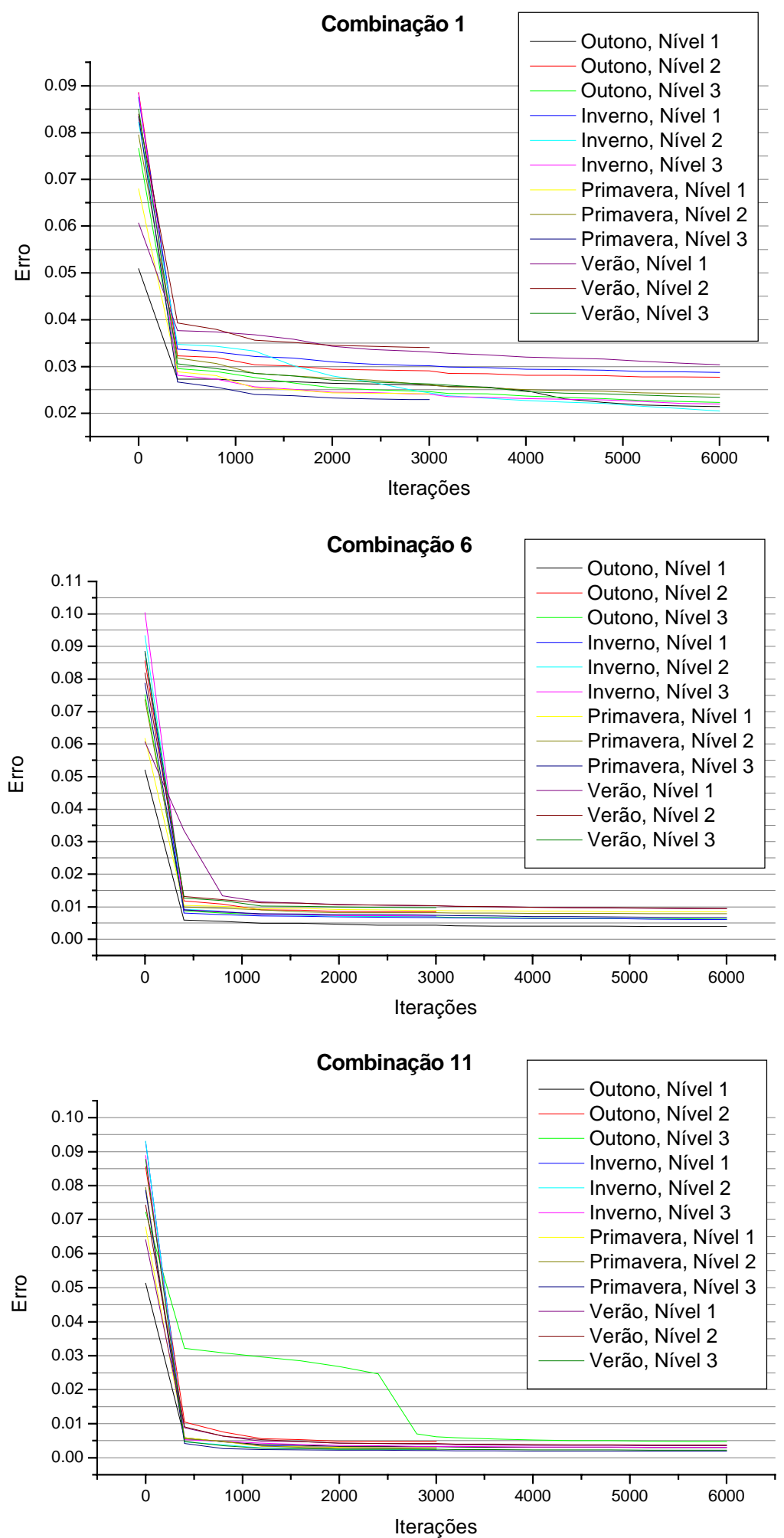

Figura 5.29 Convergência do treinamento das ANNs, primeiro conjunto. 

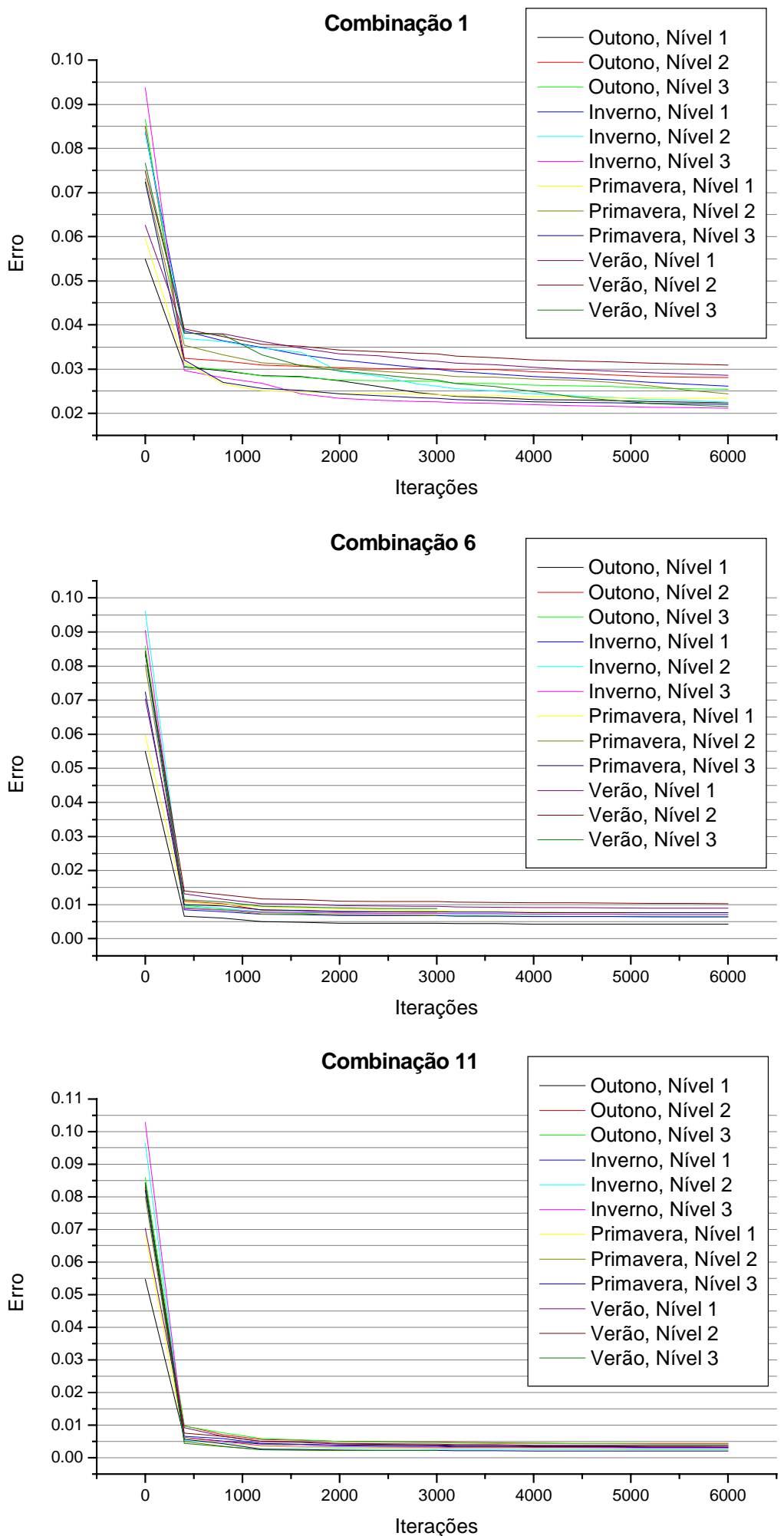

Figura 5.30 Convergência do treinamento das ANNs, segundo conjunto. 
$\mathrm{O}$ erro de treinamento permanece quase constante, na combinação 6 , em alguns casos, após 2200 iterações, e em outros casos, depois de 3000 iterações; e na combinação 11, em alguns casos após 2000 iterações; em outros casos, depois de 3500 iterações (Figura 5.29, primeiro conjunto). As redes neurais tendem a convergir, nas 4 estações e nos 3 níveis, em torno do erro de 0,02 a 0,035, na combinação 1; em torno de 0,005 a 0,01, na combinação 6; e em torno de 0,0025 a 0,005, na combinação 11 .

Nos gráficos de convergência do segundo conjunto de treinamento, Figura 5.30, combinações 1, 6 e 11, observa-se, também, uma queda abrupta do erro de treinamento antes de 1000 iterações, nas 4 estações e nos 3 níveis. Na combinação 1, o erro de treinamento começa a permanecer quase constante, em todos os casos, depois da iteração 5000. Na combinação 6, o erro de treinamento permanece quase constante, em alguns casos, após de 2000 iterações, em outros casos, após 3000 iterações. Na combinação 11, o erro de treinamento permanece quase constante a partir de 2000 iterações, em todos os casos. As redes neurais tendem a convergir, nas 4 estações e nos três níveis, em torno do erro de 0,02 a 0,032, na combinação 1; em torno de 0,005 a 0,01 , na combinação 6; e em torno de 0,002 a 0,005, na combinação 11.

Em resumo, nos dois conjuntos de treinamento, na combinação 1, o erro começa a permanecer quase constante depois de 5500 iterações, primeiro conjunto, e de 5000 iterações, segundo conjunto. Pode-se pensar que, talvez aumentando o número de iterações, o erro diminuirá. É possível; mas, observando a tendência dos gráficos, essa diminuição será muito pequena. Nas combinações 6 e 11, os números de iterações externas poderiam ter sido menores que os definidos, 6000 e 3000 iterações, porque o erro permanece quase constante antes dos números de iterações externas definidos.

A convergência das redes neurais, tanto no primeiro conjunto como no segundo conjunto, em torno do erro de 0,02 a 0,035, na combinação 1 , em torno de 0,005 a 0,01 , na combinação 6 , e em torno de 0,002 a 0,005 , na combinação 11 , 
mostra que a combinação 1 é a que menos se aproxima das tolerâncias definidas, 0,01 e 0,001, e a combinação 11 é a que mais se aproxima da tolerância 0,001. As convergências apresentadas corroboram, uma vez mais, que o primeiro grupo de combinações apresenta os maiores erros (erro relativo médio, desvio padrão, erro relativo máximo), e o terceiro grupo de combinações, os menores erros.

\section{f) Tempo de treinamento e teste}

O tempo de treinamento requerido pelas redes neurais dependeu de diferentes fatores: da combinação de variáveis de entrada, da arquitetura da rede, dos parâmetros de treinamento, do número de vetores de treinamento, do computador utilizado (Pentium 4, $1.8 \mathrm{GHz}, 512 \mathrm{MB}$ de RAM), entre outros. Por exemplo, no primeiro conjunto de treinamento, o tempo de treinamento da rede neural para as combinações de variáveis de entrada 1 e 7 foi de aproximadamente 9 minutos; e para a combinação 11, ficou em torno de 8 minutos. No segundo conjunto de treinamento, o tempo de treinamento foi de aproximadamente 5 minutos, para as combinações 1,7 e 11. Os tempos de treinamento indicados no exemplo correspondem aos treinamentos realizados com os dados da estação do outono, nível 1.

O tempo de teste das redes neurais, em todos os casos, é muito pequeno, inferior a um segundo.

\subsubsection{Considerações finais}

Nesta primeira fase, modelagem do ciclo diário de fotossíntese por estação, foram realizados treinamentos com diferentes estruturas de rede e diferentes parâmetros de treinamento. Os melhores resultados foram obtidos com uma camada escondida, de 30 e de 35 neurônios, e duas camadas escondidas, de 18 e de 15 neurônios cada. Na maioria dos casos, os melhores resultados obtiveram-se com uma tolerância de erro de 0,001 . 
Foram realizados treinamentos com 18 combinações de variáveis de entrada, para avaliar quais eram as variáveis que influíam mais na obtenção de melhores resultados. Analisando os resultados, observou-se que a presença das duas variáveis de concentração de $\mathrm{CO}_{2}$, do ar e da câmara, influem significativamente no bom desempenho das redes neurais. As outras duas variáveis que influem são a umidade relativa, do ar e da câmara. Quando nas combinações de variáveis de entrada está presente só uma das variáveis de concentração de $\mathrm{CO}_{2}$, do ar ou da câmara, e só uma das variáveis de umidade relativa, do ar ou da câmara, os erros obtidos no treinamento são os maiores. Quando estão presentes as duas variáveis de umidade relativa, do ar e da câmara, e só uma das variáveis de concentração de $\mathrm{CO}_{2}$, do ar ou da câmara, o erro diminui um pouco. Quando estão presentes as duas variáveis de concentração de $\mathrm{CO}_{2}$, e só uma das variáveis de umidade relativa, o erro diminui significativamente. Quando estão presentes as duas variáveis de concentração de $\mathrm{CO}_{2}$ e as duas variáveis de umidade relativa, o erro diminui ainda mais, e os erros obtidos no treinamento são os menores.

A combinação 1, formada pelas variáveis concentração de $\mathrm{CO}_{2}$ do ar, umidade relativa do ar, radiação fotossintética ativa, medida dentro da câmara da folha (PARi), temperatura do ar, temperatura da folha e instante da medida (tempo), foi a primeira combinação proposta, e desejada, para modelar fotossíntese. Desejavase modelar fotossíntese com as variáveis ambientais medidas no ar, fora da câmara, exceto PARi, que é a radiação que chega na folha que está sendo medida. Os resultados mostram que com a combinação 1 não se obtêm bons resultados.

Foram realizados treinamentos com dois conjuntos de dados: primeiro conjunto de treinamento, com todos os dados, e segundo conjunto de treinamento, com dados filtrados. Os melhores resultados obtiveram-se com o segundo conjunto, no que se eliminaram os valores de fotossíntese medidos na faixa de -0.099 a 0,099 $\mu \mathrm{mol} \mathrm{CO}_{2} \cdot \mathrm{m}^{-2} \cdot \mathrm{s}^{-1}$, relacionados com a calibração do medidor de fotossíntese. 
As redes neurais mostraram melhor desempenho, no primeiro conjunto de treinamento, com os dados das estações do inverno e do outono; e no segundo conjunto de treinamento, com os dados das estações do inverno e do verão.

A análise do desempenho das redes neurais por níveis, tanto no primeiro como no segundo conjunto de treinamento, mostrou que, em geral, os três níveis tiveram comportamento similar, no terceiro grupo de combinações; e os três níveis tiveram comportamento variado, no primeiro e no segundo grupo de combinações.

Finalmente, os resultados do teste mostraram que as redes neurais treinadas tiveram uma boa capacidade de generalização. Os melhores resultados foram apresentados pelo terceiro grupo de combinações. O segundo grupo de combinações mostrou também bons resultados, mas, em menor grau. Os resultados do primeiro grupo de combinações mostraram a maior diferença de erro (erro do teste - erro do treinamento), mas isso era esperado, porque esse grupo mostrou os maiores erros do treinamento. 


\subsubsection{Segunda fase: modelagem do ciclo diário de fotossíntese por ano}

\subsubsection{Considerações iniciais}

Nesta segunda fase da modelagem, o treinamento das redes neurais foi realizado com os dados das 4 estações. Desejava-se saber como respondiam as redes neurais ao conjunto de dados formados pelas 4 estações. Isto é, o desempenho das redes neurais melhoraria ou não, ao contrario, pioraria, em relação aos treinamentos realizados por estações.

Com base na experiência da primeira fase, os treinamentos foram realizados com menor número de combinações de variáveis de entrada. Escolheram-se três combinações do primeiro grupo de combinações, uma combinação do segundo grupo, e quatro combinações do terceiro grupo. Foram acrescentadas duas combinações nas quais está presente a variável estação. Na Tabela 5.23 são apresentadas as 10 combinações de variáveis utilizadas nesta fase da modelagem.

Nesta fase, os treinamentos foram também realizados com dois conjuntos de dados: primeiro conjunto com todos os dados, e segundo conjunto, com dados filtrados (sem os dados na faixa de $-0,099$ a $0,099 \mu \mathrm{mol} \mathrm{CO} 2 \cdot \mathrm{m}^{-2} \cdot \mathrm{s}^{-1}$ ).

A estrutura da rede e os parâmetros de treinamento utilizados, nesta fase, foram os mesmos que na primeira fase. Isto é, foram usados os mapas dos casos treinados, apresentados nas tabelas Tabela 5.13, segundo mapa dos casos treinados para o primeiro conjunto, e Tabela 5.14, segundo mapa dos casos treinados para o segundo conjunto. Os treinamentos realizados foram $150^{*}$ para o primeiro conjunto de treinamento e $120^{+}$para o segundo conjunto.

\footnotetext{
* 10 combinações $* 5$ casos $* 3$ níveis.

+ 10 combinações $* 4$ casos $* 3$ níveis.
} 
Tabela 5.23 - Combinações de variáveis de entrada utilizadas no treinamento.

\begin{tabular}{|c|l|}
\hline Combinação & \multicolumn{1}{|c|}{ Variáveis de entrada (VE) } \\
\hline 1 & 6 VE: Tempo, Tar, Tfol, $\mathrm{CO}_{2}$ ar, Umiar, PARi \\
\hline 2 & 6 VE: Tempo, Tar, Tfol, $\mathrm{CO}_{2}$ câ, Umiar, PARi \\
\hline 3 & 7 VE: Tempo, Planta, Tar, Tfol, $\mathrm{CO}_{2}$ ar, Umiar, PARi \\
\hline 4 & 7 VE: Tempo, Est, Tar, Tfol, $\mathrm{CO}_{2}$ ar, Umiar, PARi \\
\hline 5 & 7 VE: Tempo, Tar, Tfol, $\mathrm{CO}_{2}$ ar, $\mathrm{CO}_{2}$ câ, Umiar, PARi \\
\hline 6 & 8 VE: Tempo, Tar, Tfol, $\mathrm{CO}_{2}$ ar, $\mathrm{CO}_{2}$ câ, Umiar, Umicâ, PARo \\
\hline 7 & 8 VE: Tempo, Tar, Tfol, $\mathrm{CO}_{2}$ ar, $\mathrm{CO}_{2}$ câ, Umiar, Umicâ, PARi \\
\hline 8 & $\begin{array}{l}9 \text { VE: Tempo, Tar, Tfol, } \mathrm{CO}_{2} \text { ar, } \mathrm{CO}_{2} \text { câ, Umiar, Umicâ, PARi, } \\
\text { PARo }\end{array}$ \\
\hline 9 & $\begin{array}{l}\text { PARi, PARo } \\
10 \text { VE: Tempo, Est, Tar, Tfol, } \mathrm{CO}_{2} \text { ar, } \mathrm{CO}_{2} \text { câ, Umiar, Umicâ, } \\
\text { PARi, PARo }\end{array}$ \\
\hline 10 & \begin{tabular}{l}
10 \\
\hline
\end{tabular} \\
\hline
\end{tabular}

Observação: abreviatura das variáveis de entrada segundo a definição da tabela 4.8.

Na Tabela 5.24 é apresentado o número de vetores de treinamento e de teste utilizados nesta fase da modelagem, para os três níveis, e para os dois conjuntos de treinamento.

Tabela 5.24 - Número de vetores de treinamento e de teste.

\begin{tabular}{|l|r|r|r|r|r|r|}
\hline & \multicolumn{3}{|c|}{$\begin{array}{c}\text { Primeiro conjunto de } \\
\text { treinamento }\end{array}$} & \multicolumn{3}{c|}{$\begin{array}{c}\text { Segundo conjunto de } \\
\text { treinamento }\end{array}$} \\
\cline { 2 - 7 } & Nível 1 & Nível 2 & \multicolumn{1}{|c|}{ Nível 3 } & \multicolumn{1}{c|}{ Nível 1 } & \multicolumn{1}{c|}{ Nível 2 } & \multicolumn{1}{|c|}{ Nível 3 } \\
\hline $\begin{array}{l}\text { Vetores de } \\
\text { treinamento }\end{array}$ & 2271 & 2275 & 2265 & 1981 & 2018 & 2053 \\
\hline $\begin{array}{l}\text { Vetores de } \\
\text { teste }\end{array}$ & 970 & 974 & 970 & 850 & 860 & 880 \\
\hline
\end{tabular}




\subsubsection{Resultados}

Feitas essas considerações, a seguir serão apresentados os resultados obtidos na segunda fase da modelagem, treinamentos com os dados das 4 estações.

$\mathrm{Na}$ Tabela 5.25 são apresentados os casos com os quais se obtiveram os melhores resultados, para os dois conjuntos de treinamento e para os três níveis. Para o primeiro conjunto de treinamento, os casos estão indicados com as letras A, B, C, D e E, em correspondência com a Tabela 5.13, casos para o treinamento com todos os dados. Para o segundo conjunto, os casos estão indicados com as letras A, B, C e $\mathrm{D}$, as quais correspondem à Tabela 5.14, casos para o treinamento com dados filtrados. A numeração da combinação corresponde à Tabela 5.23, combinações de variáveis de entrada.

Tabela 5.25 - Casos com os que se obtiveram os melhores resultados no treinamento das ANNs.

\begin{tabular}{|c|c|c|c|c|c|c|}
\hline \multirow{2}{*}{ Combinação* } & \multicolumn{3}{|c|}{$\begin{array}{c}\text { Primeiro conjunto de } \\
\text { treinamento }\end{array}$} & \multicolumn{3}{c|}{$\begin{array}{c}\text { Segundo conjunto de } \\
\text { treinamento }\end{array}$} \\
\cline { 2 - 7 } & Nível 1 & Nível 2 & Nível 3 & Nível 1 & Nível 2 & Nível 3 \\
\hline 1 & C & E & E & B & D & D \\
\hline 2 & E & E & E & C & D & D \\
\hline 3 & C & E & D & D & D & D \\
\hline 4 & A & E & C & D & D & C \\
\hline 5 & D & D & D & C & C & C \\
\hline 6 & C & C & E & B & D & B \\
\hline 7 & C & C & C & B & C & B \\
\hline 8 & B & D & C & C & B & C \\
\hline 9 & C & E & C & B & B & C \\
\hline 10 & C & C & C & B & C & C \\
\hline
\end{tabular}

* Conforme a Tabela 5.23.

N1: Nível 1, N2: Nível 2, N3: Nível 3.

A, B, C, D, E: casos conforme as Tabela 5.13 e Tabela 5.14 
Os resultados dos casos mostrados na Tabela 5.25, casos com que se obtiveram os melhores resultados, são apresentados nas tabelas B.1 a B.4, do apêndice B. Nessas tabelas são mostrados o erro relativo médio, o desvio padrão e o erro relativo máximo, para os três níveis e para as 10 combinações. A Tabela B.1 mostra os erros obtidos no treinamento do primeiro conjunto, e os erros obtidos no teste desses treinamentos são mostrados na Tabela B.2. As tabelas B.3 e B.4 apresentam os erros obtidos no segundo conjunto, no treinamento e no teste, respectivamente.

Observando os erros, nas tabelas B.1 a B.4, pode-se apreciar a formação de três grupos, como na primeira fase da modelagem, o que era de se esperar. Um primeiro grupo formado pelas combinações 1, 2, 3 e 4, um segundo grupo representado só pela combinação 5, e um terceiro grupo formado pelas combinações $6,7,8,9$, e 10. Cada um desses grupos mostra uma característica: o erro relativo médio, o desvio padrão e o erro relativo máximo são similares. O primeiro grupo apresenta os maiores erros, o terceiro grupo os menores erros, e o segundo grupo erros menores que o primeiro e maiores que o terceiro.

Para mostrar os resultados da modelagem do ciclo diário de fotossíntese, selecionou-se a combinação 1 do primeiro grupo, a combinação 5, única representante do segundo grupo, e a combinação 7 do terceiro grupo. Esses resultados são apresentados na Figura 5.31, na Figura 5.32 e na Figura 5.33, que correspondem às combinações 1,5 e 7 , respectivamente, e ao nível 1. Cada uma dessas figuras mostra os resultados do treinamento com os respectivos resultados do teste, do primeiro e do segundo conjunto de treinamento. Nessas figuras, são mostrados gráficos do ciclo diário de fotossíntese, dos valores calculados pelas ANNs, pontos vermelhos, e dos valores medidos, pontos pretos. 
a) Com todos os dados
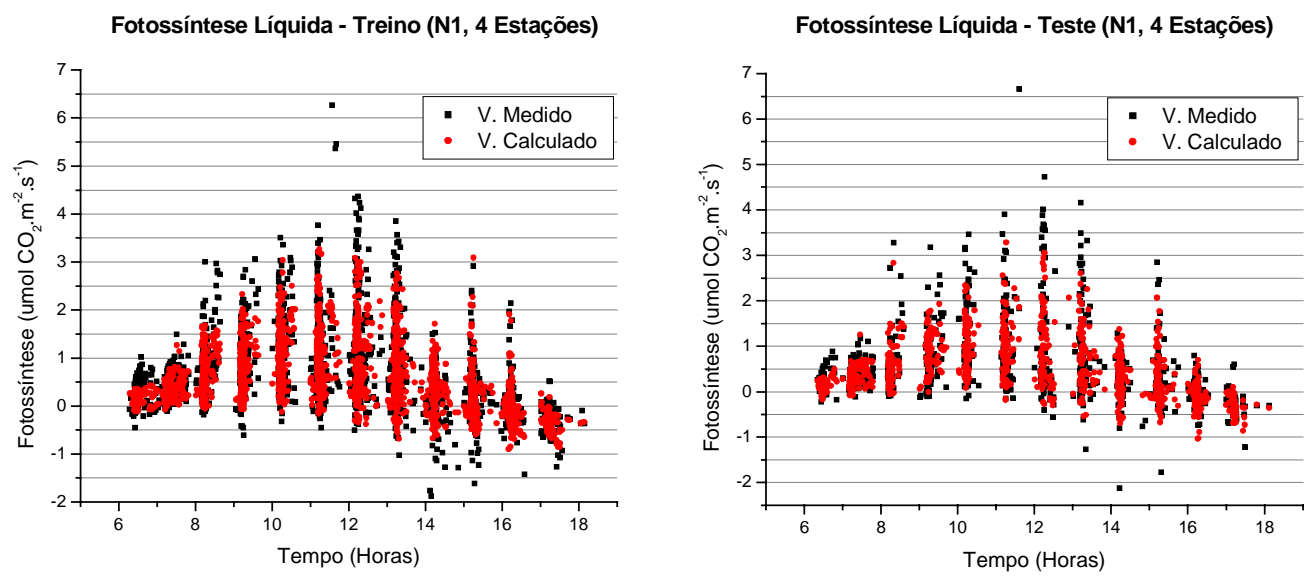

b) Com dados filtrados
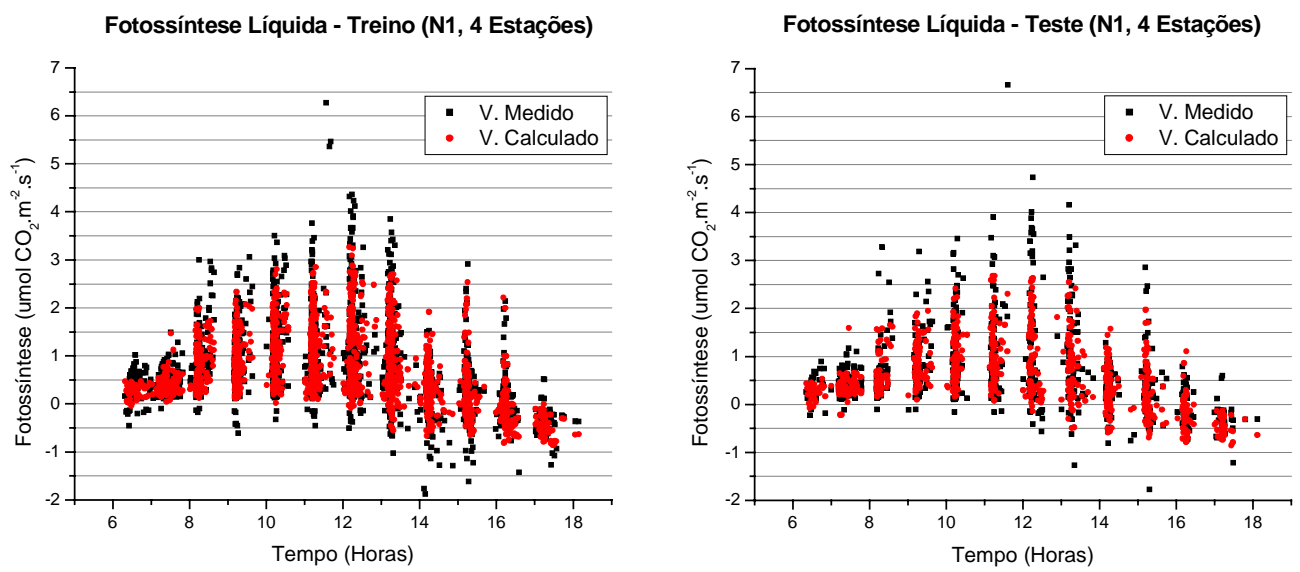

Figura 5.31 Resultados da modelagem do ciclo diário de fotossíntese para a combinação 1. 
a) Com todos os dados
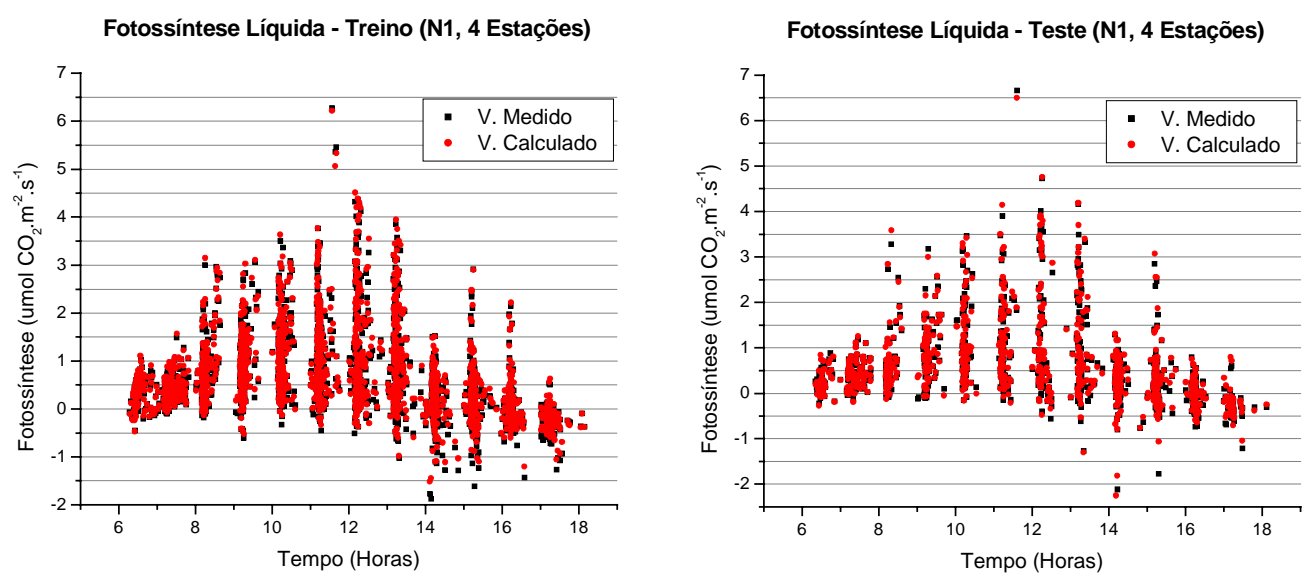

b) Com dados filtrados
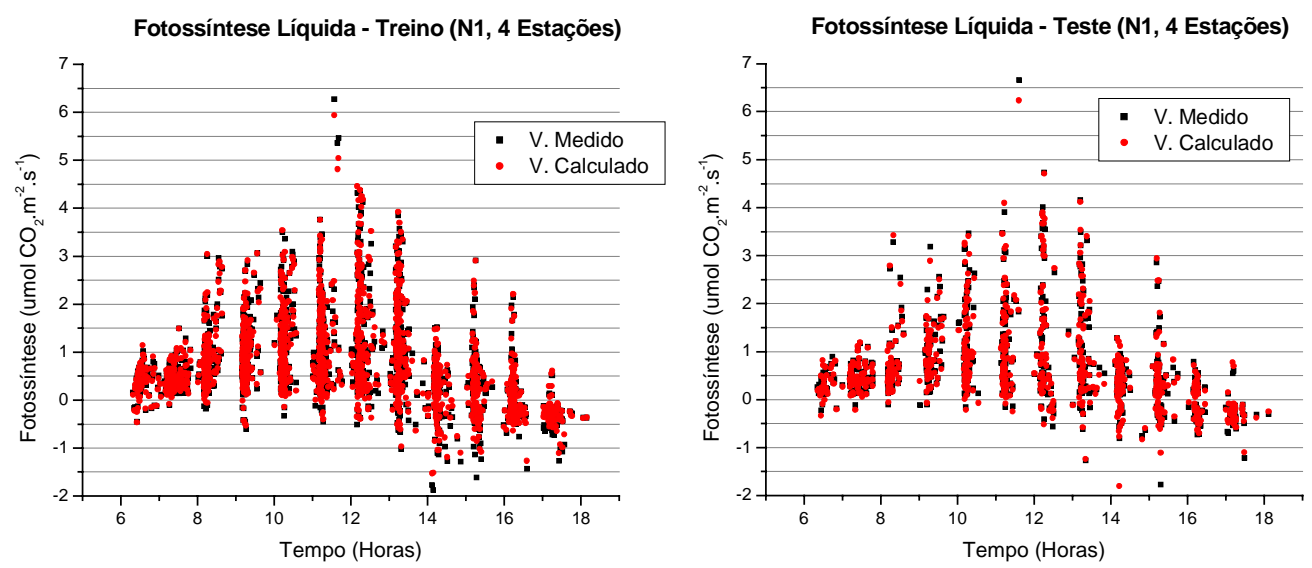

Figura 5.32 Resultados da modelagem do ciclo diário de fotossíntese para a combinação 5 . 
a) Com todos os dados
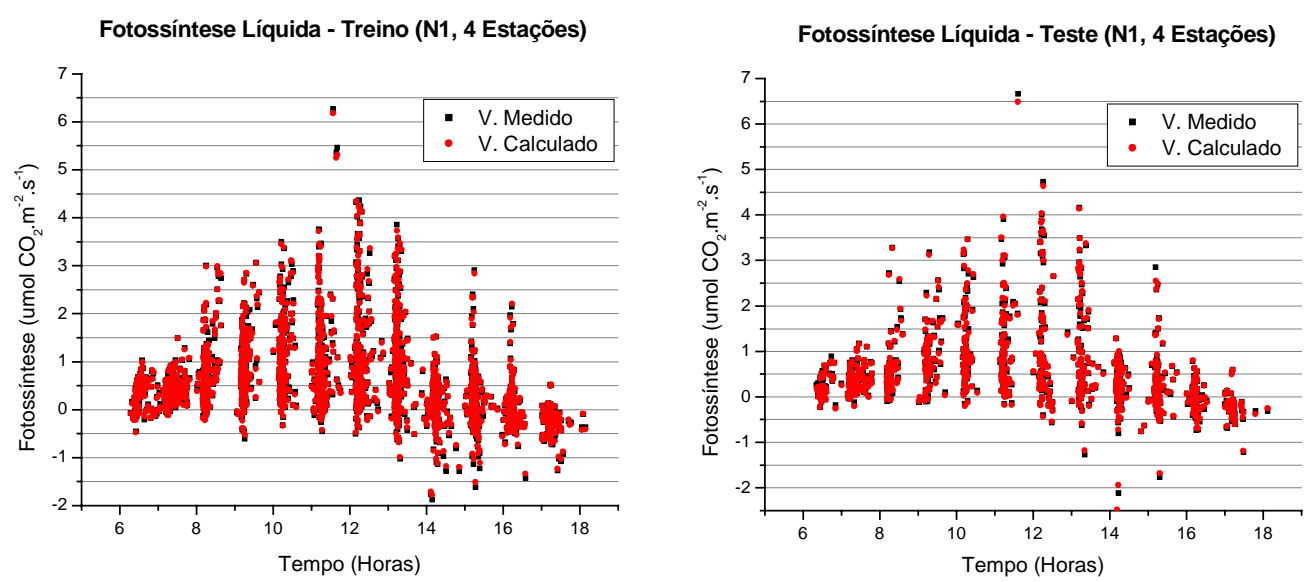

b) Com dados filtrados
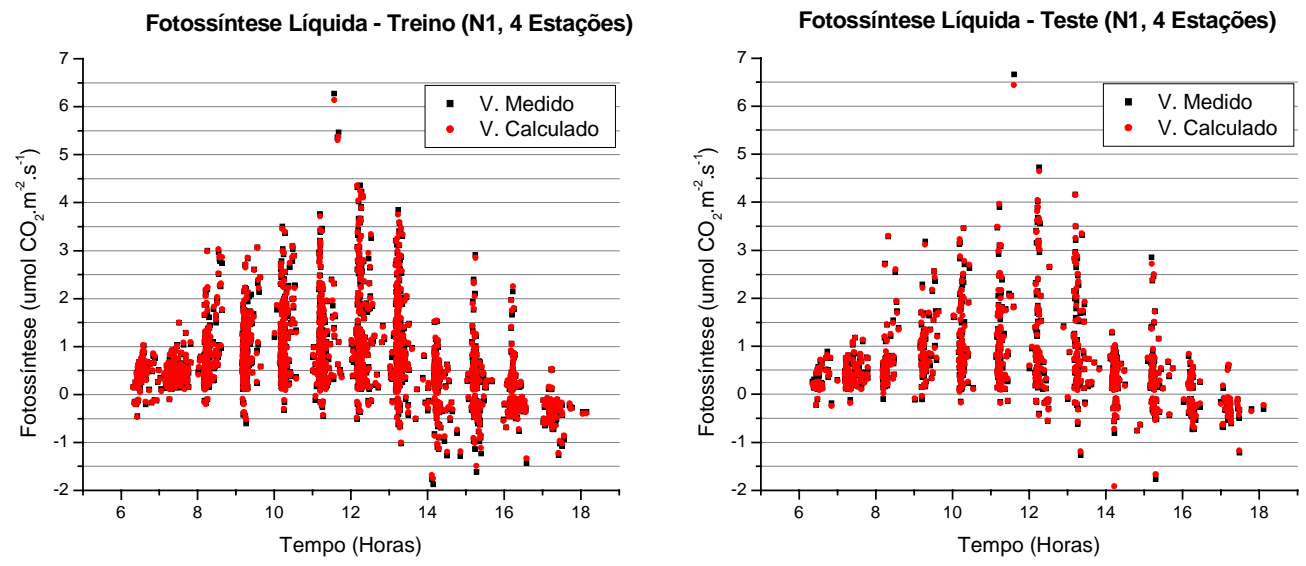

Figura 5.33 Resultados da modelagem do ciclo diário de fotossíntese para a combinação 7 .

Na Figura 5.31, resultados da combinação 1, aprecia-se que os valores calculados pelas ANNs aproximam-se dos valores reais, os valores medidos, mas existe uma margem erro considerável. Na Figura 5.32, resultados da combinação 5, observa-se que existe uma melhor aproximação entre os valores calculados pelas ANNs e os valores medidos; a margem de erro é significativamente menor, em comparação com os resultados da combinação 1. Na Figura 5.33, resultados da combinação 7, nota-se que a aproximação entre os valores calculados pelas ANNs e os valores medidos é bastante maior, os resultados desta combinação são melhores que os da combinação 5, e apreciavelmente melhores que os da combinação 1 . 
Portanto, reitera-se mais uma vez que os melhores resultados são apresentados pelo terceiro grupo, seguido pelo segundo grupo, e que o primeiro grupo apresenta o pior desempenho.

Como foi indicado, os resultados apresentados na Figura 5.31, na Figura 5.32 e na Figura 5.33 correspondem ao nível 1. Os resultados dos níveis 2 e 3, gráficos do ciclo diário de fotossíntese, valores calculados pelas ANNs e valores medidos, são similares ao nível 1, razão pela qual não são apresentados.

Como exemplo, as listas parciais dos resultados do treinamento e teste das combinações 1,5 e 7, tanto do primeiro como do segundo conjunto de treinamento, correspondentes ao nível 1, são mostradas nas tabelas B.5 a B.16, do apêndice B. Nessas listas são apresentados os valores das variáveis de entrada, o valor da variável de saída real, e o valor da variável de saída calculado pela rede.

\subsubsection{Análise dos resultados}

A análise dos resultados compreenderá os mesmos pontos que foram tratados na primeira fase da modelagem, exceto resultados por estação. Esses pontos são:
a. Influência das combinações de variáveis de entrada
b. Resultados do primeiro e segundo conjunto de treinamento
c. Resultados por nível
d. Teste das ANNs
e. Convergência das ANNs
f. Tempo de treinamento e teste

\section{a) Influência das combinações de variáveis de entrada}

Neste item será analisada a influência das variáveis de entrada no treinamento das redes neurais. Para isso, serão utilizados os resultados dos treinamentos das 10 
combinações de variáveis de entrada, mostradas na Tabela 5.23. Na Figura 5.34 são apresentados os resultados desses treinamentos, gráficos do erro relativo médio, dos três níveis, em função das 10 combinações de variáveis de entrada, tanto para o primeiro como para o segundo conjunto de treinamento.

Nos gráficos da Figura 5.34 pode ser apreciada claramente a formação dos três grupos de combinações, que foram observados nas tabelas B.1 a B.4, do apêndice B. O primeiro grupo, formado pelas combinações 1, 2, 3 e 4, apresenta os maiores erros. O segundo grupo, representado pela combinação 5, mostra erros significativamente menores que o primeiro grupo. O terceiro grupo, formado pelas combinações 6, 7, 8, 9 e 10, apresenta os menores erros. A formação dos três grupos de combinações era esperarada, pois como foi indicado no item 5.2.2.1, considerações iniciais, foram escolhidas algumas das combinações de cada um dos três grupos da primeira fase da modelagem. Mas, também, foi adicionada a variável de entrada estação em duas dessas combinações. Portanto, não será realizada uma análise detalhada das combinações de variáveis de entrada, exceto aquelas que têm a variável estação.
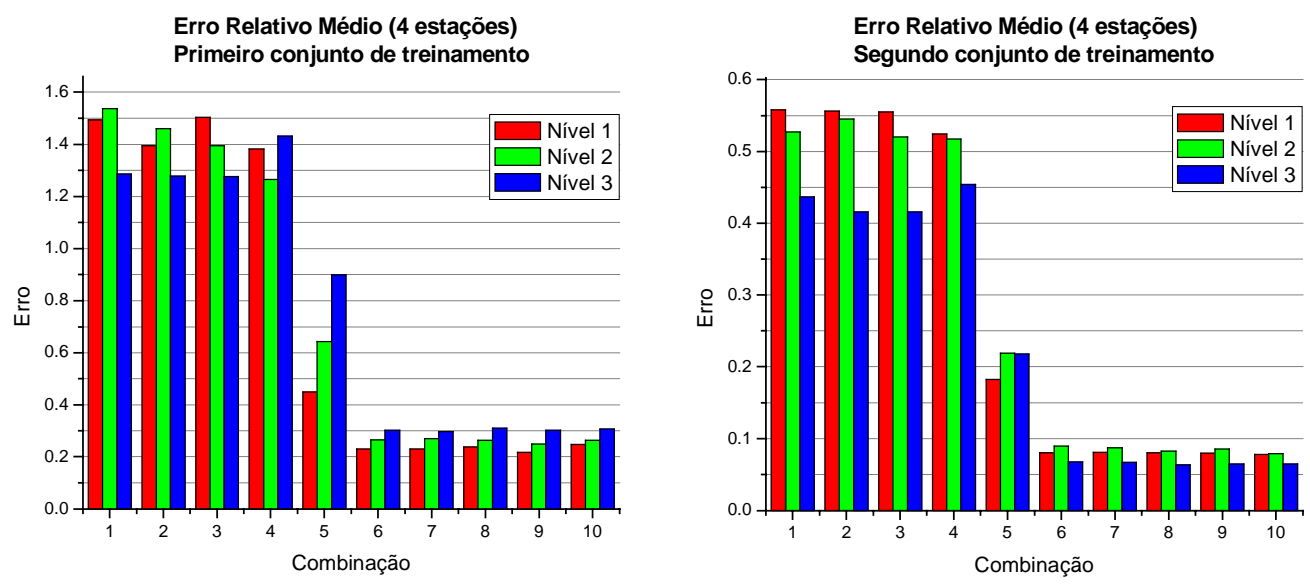

Figura 5.34 Resultados dos treinamentos, das 10 combinações de variáveis de entrada.

Observando a Tabela 5.23, combinações de variáveis de entrada, nota-se que nas combinações 1, 2, 3 e 4 está presente só uma variável de concentração de $\mathrm{CO}_{2}$, 
do ar ou da câmara, e uma variável de umidade relativa, a do ar. Por isso, apresentam os maiores erros. A combinação 4 é formada pelas variáveis da combinação 1, mais a variável estação. O propósito dessa combinação era saber se a presença de uma variável que identifique a estação na qual foi realizada a medida melhoraria ou não o desempenho das redes neurais. Na Figura 5.34 aprecia-se que, nos níveis 1 e 2, o erro relativo médio dessa combinação é menor que o erro das combinações 1,2 e 3 , no primeiro conjunto de treinamento; e ligeiramente menor, no segundo conjunto de treinamento. Mas, no nível 3, o erro dessa combinação é maior que o erro das três primeiras combinações, no primeiro conjunto de treinamento; e ligeiramente maior, no segundo conjunto de treinamento. Porém, esses resultados mostram que houve uma ligeira influência da variável estação, na melhora do desempenho das ANNs, nos níveis 1 e 2; mas, no nível 3, deu-se o oposto.

A combinação 5 mostra erros significativamente menores que as primeiras 4 combinações, pois nesta combinação, estão presentes as duas variáveis de concentração de $\mathrm{CO}_{2}$, do ar e da câmara, observar a Tabela 5.23.

As combinações 6, 7, 8, 9, e 10 apresentam os menores erros, porque nessas combinações estão presentes as duas variáveis de concentração de $\mathrm{CO}_{2}$, do ar e da câmara, e as duas variáveis de umidade relativa, do ar e da câmara. A combinação 9 é formada pelas 9 variáveis de entrada medidas, além da variável estação. Observando o erro relativo médio dessa combinação, na Figura 5.34, e das combinações $6,7,8$ e 10, tanto no primeiro como no segundo conjunto de treinamento, nota-se que apresentam erros similares. Portanto, esses resultados indicam que a rede neural teve a capacidade de generalizar, sem a necessidade de identificar a estação na qual foi realizada a medida.

Na Tabela 5.26 é mostrado o erro relativo médio, por níveis, tanto do primeiro como do segundo conjunto de treinamento, correspondente às combinações 1, 5 e 7, para evidenciar, uma vez mais, a influência das duas variáveis de concentração de $\mathrm{CO}_{2}$, e as duas variáveis de umidade relativa. A combinação 1 
pertence ao primeiro grupo de combinações, a combinação 5 ao segundo grupo, e a combinação 7 ao terceiro grupo de combinações.

Tabela 5.26 - Influência das variáveis de entrada nos resultados do treinamento.

\begin{tabular}{|c|r|l|r|l|r|r|}
\hline \multirow{2}{*}{ Combinação } & \multicolumn{5}{|c|}{ Erro relativo médio (\%) } \\
\cline { 2 - 7 } & \multicolumn{2}{|c|}{ Nível 1 } & \multicolumn{2}{|c|}{ Nível 2 } & \multicolumn{2}{c|}{ Nível 3 } \\
\cline { 2 - 7 } & $\begin{array}{l}\text { Todos } \\
\text { os dados }\end{array}$ & $\begin{array}{l}\text { Dados } \\
\text { filtrados }\end{array}$ & $\begin{array}{l}\text { Todos } \\
\text { os dados }\end{array}$ & $\begin{array}{l}\text { Dados } \\
\text { filtrados }\end{array}$ & $\begin{array}{l}\text { Todos } \\
\text { os dados }\end{array}$ & $\begin{array}{l}\text { Dados } \\
\text { filtrados }\end{array}$ \\
\hline $\mathbf{1}$ & 149.4 & 55.8 & 153.8 & 52.7 & 128.5 & 43.6 \\
\hline $\mathbf{5}$ & 44.9 & 18.2 & 64.2 & 21.9 & 89.9 & 21.8 \\
\hline $\mathbf{7}$ & 22.9 & 8.1 & 26.9 & 8.7 & 29.7 & 6.7 \\
\hline
\end{tabular}

Em resumo, os resultados dos treinamentos com diferentes combinações de variáveis de entrada mostram que as variáveis que influem significativamente no bom desempenho das redes neurais são as duas variáveis de concentração de $\mathrm{CO}_{2}$. As variáveis de umidade relativa, do ar e da câmara, influem também, mas em menor grau. A variável estação mostrou não ter uma influência significativa no desempenho das redes neurais.

\section{b) Resultados do primeiro e segundo conjunto de treinamento}

Os resultados dos treinamentos do primeiro conjunto, treinamento com todos os dados, e do segundo conjunto, treinamentos com dados filtrados, serão analisados neste item. Na Figura 5.35 são mostrados esses resultados, gráficos do erro relativo médio em função das 10 combinações de variáveis de entrada, dos treinamentos com todos os dados e com dados filtrados, dos três níveis. Nos gráficos dessa figura, também, nota-se a formação dos três grupos de combinações.

Observando os gráficos do erro relativo médio da Figura 5.35, aprecia-se que, como na primeira fase, o desempenho das redes neurais é significativamente melhor 
com dados filtrados. O primeiro conjunto de treinamento apresenta erros apreciavelmente maiores que os do segundo conjunto de treinamento.

Para mostrar a porcentagem de diminuição do erro obtido nos treinamentos com todos os dados para o erro obtido nos treinamentos com dados filtrados foi elaborada a Tabela 5.27. Nessa tabela é apresentado o erro relativo médio dos treinamentos, com todos os dados e com dados filtrados, e a porcentagem da diminuição do erro, dos três grupos de combinações e dos três níveis. O erro relativo médio, apresentado na tabela, é a média dos erros relativos médios do grupo de combinações.
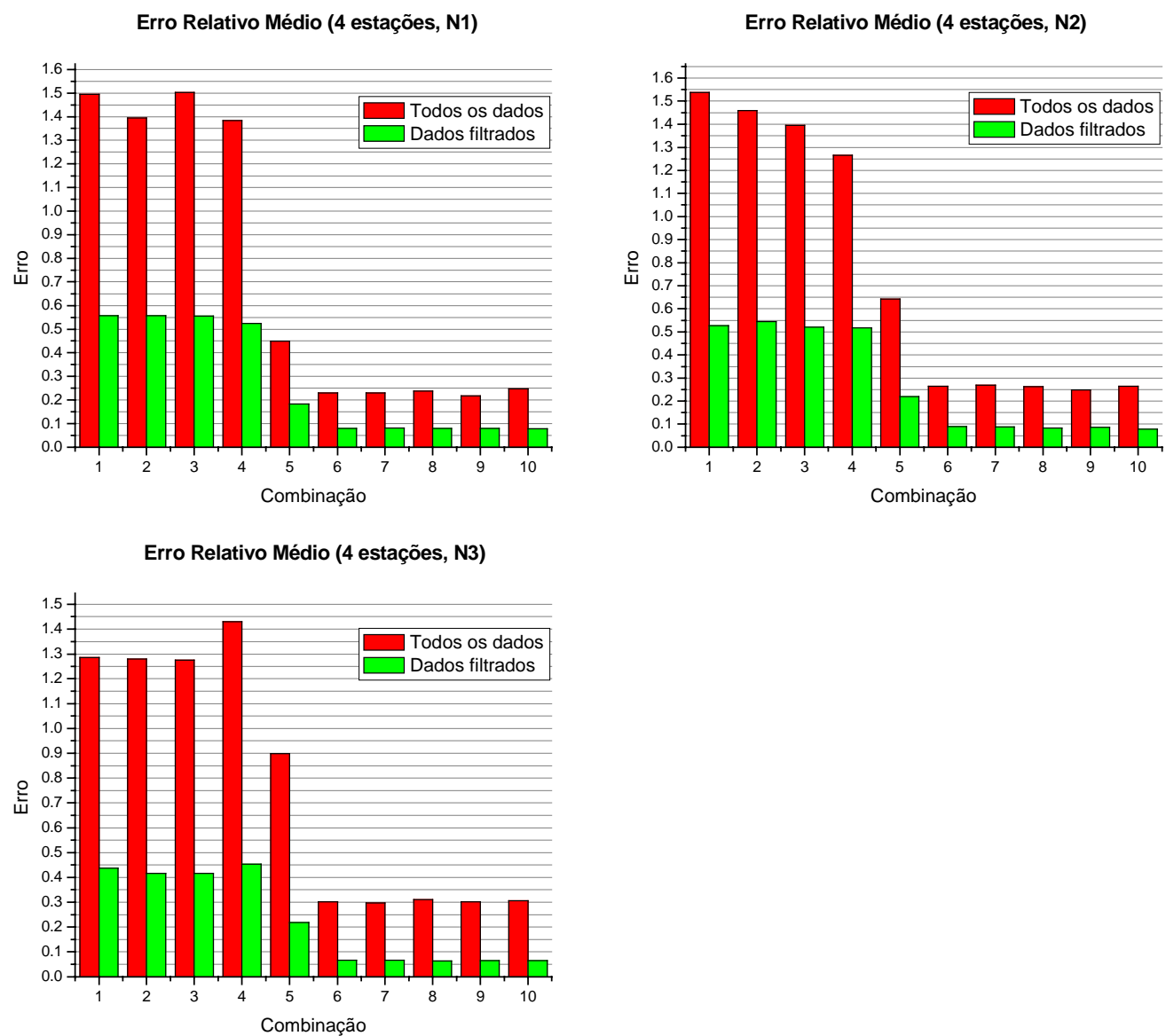

Figura 5.35 Resultados do primeiro e segundo conjunto de treinamento. 
Tabela 5.27 - Comparação dos resultados do treinamento, com todos os dados e com dados filtrados.

\begin{tabular}{|c|c|c|c|c|c|c|c|c|c|}
\hline \multirow[t]{3}{*}{ Nível } & \multicolumn{3}{|c|}{$\begin{array}{l}1^{\circ} \text { grupo de } \\
\text { combinações }\end{array}$} & \multicolumn{3}{|c|}{$\begin{array}{l}2^{\circ} \text { grupo de } \\
\text { combinações }\end{array}$} & \multicolumn{3}{|c|}{$\begin{array}{l}3^{\circ} \text { grupo de } \\
\text { combinações }\end{array}$} \\
\hline & \multicolumn{2}{|c|}{$\begin{array}{ll}\text { Erro } & \text { relativo } \\
\text { médio } & \\
\end{array}$} & \multirow[t]{2}{*}{$\mathrm{DE}$} & \multicolumn{2}{|c|}{$\begin{array}{l}\text { Erro relativo } \\
\text { médio }\end{array}$} & \multirow[t]{2}{*}{$\mathrm{DE}$} & \multicolumn{2}{|c|}{$\begin{array}{|ll|}\text { Erro relativo } \\
\text { médio }\end{array}$} & \multirow[t]{2}{*}{$\mathrm{DE}$} \\
\hline & TD & DF & & TD & DF & & TD & $\mathrm{DF}$ & \\
\hline 1 & $144 \%$ & $55 \%$ & $62 \%$ & $45 \%$ & $18 \%$ & $60 \%$ & $29 \%$ & $10 \%$ & $66 \%$ \\
\hline 2 & $141 \%$ & $53 \%$ & $62 \%$ & $64 \%$ & $22 \%$ & $66 \%$ & $33 \%$ & $11 \%$ & $67 \%$ \\
\hline 3 & $132 \%$ & $43 \%$ & $67 \%$ & $90 \%$ & $22 \%$ & $76 \%$ & $38 \%$ & $8 \%$ & $79 \%$ \\
\hline
\end{tabular}

TD: Todos os dados, DF: Dados filtrados, DE: Diminuição do erro

Observando os valores do erro relativo médio da Tabela 5.27, aprecia-se a diferença significativa que houve entre os resultados do treinamento com todos os dados e os resultados do treinamento com dados filtrados. A diminuição do erro nos três níveis é acima de 60\%: no primeiro grupo de combinações o erro diminui entre 62 a $67 \%$, no segundo grupo o erro diminui na faixa de 60 a $76 \%$, e no terceiro grupo o erro diminui entre 66 a $79 \%$.

Os resultados apresentados confirmam, uma vez mais, a influência considerável dos valores de fotossíntese, medidos na faixa de -0.099 a 0,099 $\mu \mathrm{mol} \mathrm{CO}_{2} \cdot \mathrm{m}^{-2} \cdot \mathrm{s}^{-1}$, relacionados com a calibração do medidor de fotossíntese, no desempenho das redes neurais.

\section{c) Resultados por nível}

Como os treinamentos das redes neurais foram realizados por níveis, neste item serão analisados os resultados desses treinamentos. Isto é, com os dados de que nível, 1, 2 ou 3, obteve-se o melhor desempenho nos treinamentos das ANNs.

Na Figura 5.34, do item a, influência das combinações de variáveis de entrada, foram apresentados gráficos do erro relativo médio dos treinamentos, dos 
três níveis, em função das 10 combinações de variáveis de entrada, para o primeiro e o segundo conjunto de treinamento. Esses gráficos serão utilizados para a análise dos resultados por níveis.

Observando o gráfico do erro relativo médio, do primeiro conjunto, na Figura 5.34, aprecia-se que o nível 1 mostra os menores erros no segundo e no terceiro grupo de combinações. O nível 3 mostra os menores erros no primeiro grupo de combinações, exceto na combinação 4, na qual apresenta o maior erro; mas esse nível 3 apresenta os maiores erros no segundo e terceiro grupo de combinações. O nível 2 apresenta os maiores erros nas combinações 1 e 2, e o menor erro na combinação 4.

No gráfico do erro relativo médio, do segundo conjunto de treinamento, Figura 5.34, nota-se que o nível 1 apresenta os maiores erros no primeiro grupo de combinações e o menor no segundo grupo. O nível 2 mostra os maiores erros no terceiro grupo de combinações. O nível 3 apresenta os menores erros no primeiro e no terceiro grupo de combinações.

Em resumo, no primeiro conjunto de treinamento, os níveis 1 e 3 apresentam os melhores resultados. O nível 1, no segundo e terceiro grupo de combinações, e o nível 3, no primeiro grupo de combinações. No segundo conjunto de treinamento, o nível 3 apresenta os melhores resultados, exceto na combinação 5, na qual o nível 1 mostra o melhor resultado.

\section{d) Teste das ANNs}

Os resultados do teste das redes neurais treinadas serão analisados a seguir. Na Figura 5.36 são mostrados gráficos do erro relativo médio, do treino e do teste das ANNs, em função das 10 combinações de variáveis de entrada, para cada um dos três níveis, e para os dois conjuntos de treinamento. 
Como já foi mencionado, na análise do teste das ANNs, na primeira fase da modelagem, a magnitude da diferença de erro (erro do teste - erro do treinamento) indica a capacidade de generalização da rede treinada. Quanto menor é a diferença do erro, maior é a capacidade de generalização que teve a rede.
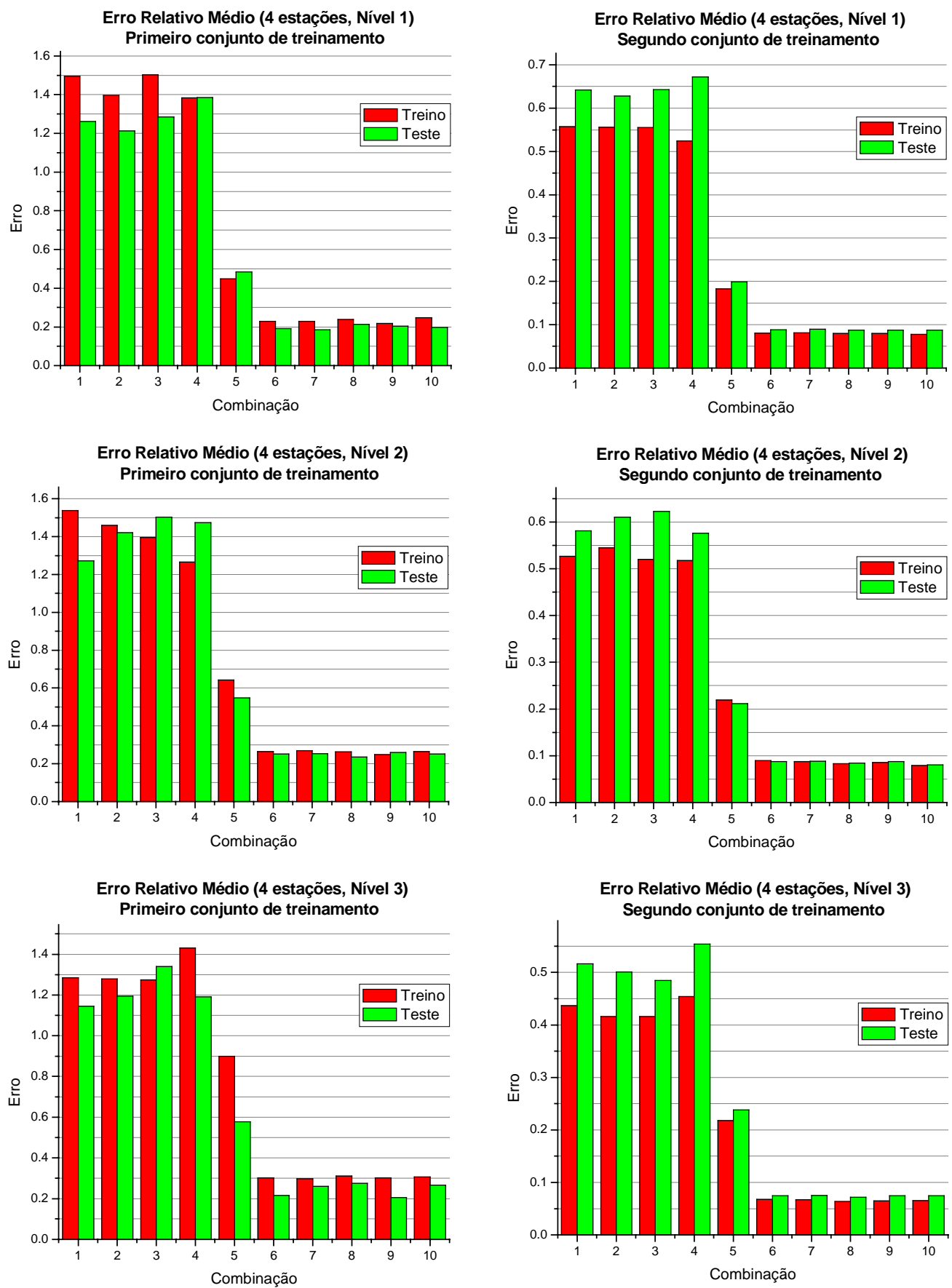

Figura 5.36 Resultados do treino e do teste das ANNs 
Observando os gráficos da Figura 5.36, verifica-se que os resultados do teste foram bons, as ANNs treinadas tiveram uma boa capacidade de generalização, ante um conjunto de dados que não lhes foram apresentados durante o treinamento. No primeiro conjunto de treinamento, nos três níveis, na maioria das combinações, o erro do teste é menor que o erro do treinamento. No segundo conjunto, o erro do teste é maior que o erro do treino no primeiro grupo de combinações, e quase igual ou ligeiramente maior no segundo e terceiro grupo de combinações.

Para apreciar melhor os resultados do teste, na Figura 5.37 são apresentados gráficos com a diferença de erro (erro do teste - erro do treinamento), dos três níveis, em função das 10 combinações de variáveis de entrada, para o primeiro e segundo conjunto de treinamento. Os gráficos dessa figura corroboram o mencionado no parágrafo anterior. No primeiro conjunto de treinamento, quase todas as combinações e os três níveis apresentam diferenças de erro negativo, exceto a combinação 3, níveis 2 e 3, a combinação 4, nível 2, e a combinação 5, nível 1 .
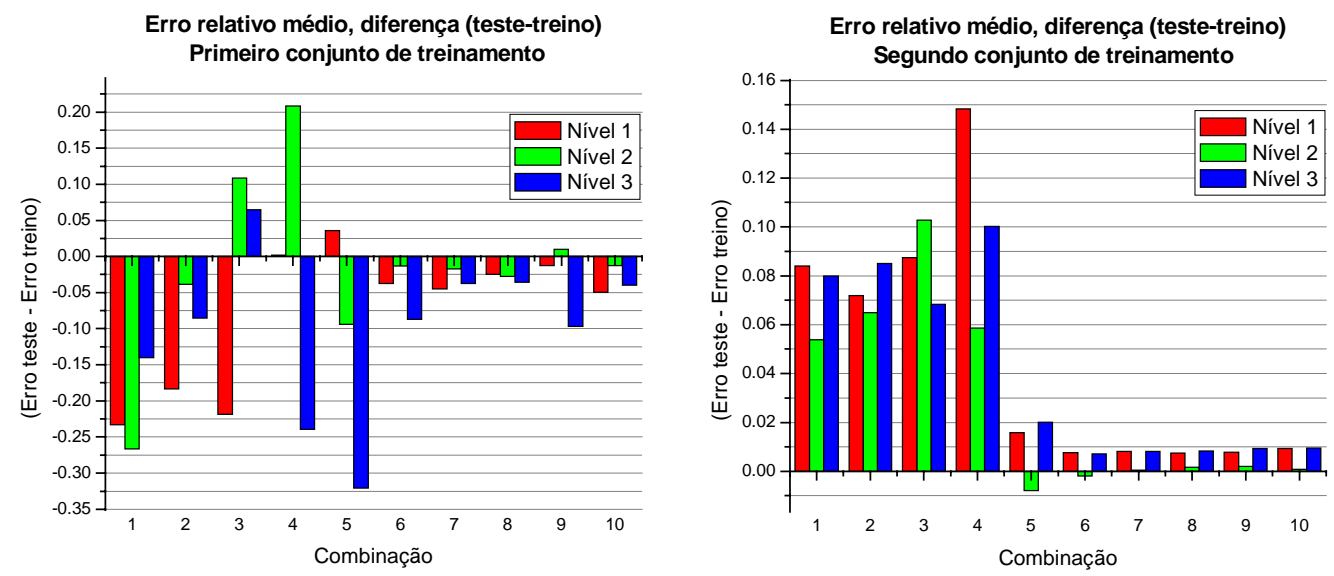

Figura 5.37 Diferença do erro relativo médio, entre o teste e o treino das ANNs, dos três níveis.

Observando o gráfico do segundo conjunto de treinamento, Figura 5.37, aprecia-se que, no primeiro grupo de combinações, nos três níveis, as diferenças de erro são menores que $9 \%$, exceto a combinação 3, nível 3, que apresenta uma 
diferença de erro menor que $11 \%$, e a combinação 4, níveis 1 e 3, que mostram diferenças de erro inferior a $15 \%$ e a $10 \%$, respectivamente. No segundo grupo de combinações, nos três níveis, as diferenças de erro são inferiores a $2 \%$. No terceiro grupo de combinações, nos três níveis, as diferenças de erro são menores que $1 \%$.

Comparando os resultados do teste do primeiro conjunto de treinamento com os do segundo conjunto, poder-se-ia pensar que tiveram melhor desempenho as redes neurais do primeiro conjunto. Mas, as diferenças de erro negativas, apresentadas pelo primeiro conjunto, estão influenciadas pelos valores de fotossíntese, medidos na faixa de -0.099 a $0,099 \mu \mathrm{mol} \mathrm{CO}_{2} \cdot \mathrm{m}^{-2} \cdot \mathrm{s}^{-1}$. Isto se verifica ao apreciar os resultados do teste do segundo conjunto, treinamentos sem os dados de fotossíntese na faixa de -0.099 a $0,099 \mu \mathrm{mol} \mathrm{CO} 2 \cdot \mathrm{m}^{-2} \cdot \mathrm{s}^{-1}$, onde as diferenças de erro são positivas, exceto nas combinações 5 e 6, nível 2.

Em resumo, os resultados do teste mostram que as redes neurais tiveram bom desempenho. No segundo conjunto de treinamento, aprecia-se que os maiores erros do teste são apresentados pelo primeiro grupo de combinações, os menores erros são mostrados pelo terceiro grupo de combinações, e o segundo grupo de combinações apresenta erros menores que o primeiro grupo e maiores que o terceiro grupo. Esses resultados dos grupos de combinações são admissíveis, pois a magnitude de diferença de erro apresentada pelos três grupos está de acordo com a magnitude do erro apresentado nos treinamentos pelos três grupos de combinações. No primeiro conjunto, mesmo que os resultados estejam influenciados pelos valores de fotossíntese na faixa de -0.099 a $0,099 \mu \mathrm{mol} \mathrm{CO} 2 \cdot \mathrm{m}^{-2} \cdot \mathrm{s}^{-1}$, observa-se que as maiores oscilações de diferença de erro se dão no primeiro e segundo grupo de combinações, e as menores oscilações no terceiro grupo de combinações.

\section{e) Convergência das ANNs}

Como foi mencionado, os treinamentos das ANNs, nesta segunda fase da modelagem, foram realizados com as mesmas arquiteturas de rede e parâmetros de 
treinamento da primeira fase da modelagem. As ANNs foram treinadas com $6000 \mathrm{ou}$ 3000 iterações externas, e com tolerância de erro de 0,01 ou 0,001, observar a Tabela 5.13 e a Tabela 5.14, mapas dos casos treinados do primeiro e segundo conjunto de treinamento, respectivamente. Tendo em consideração os valores dos parâmetros de treinamento, iterações externas e tolerância de erro, e as considerações dadas na análise da convergência das ANNs, na primeira fase da modelagem, a seguir será analisada a convergência das redes neurais treinadas, nesta segunda fase da modelagem. Para esse propósito foi escolhida uma combinação de cada grupo de combinações: a combinação 1 do primeiro grupo, a combinação 5, única representante do segundo grupo, e a combinação 7 do terceiro grupo.

Na Figura 5.38 e na Figura 5.39 são apresentados gráficos da convergência das ANNs, para as três combinações indicadas no parágrafo anterior. Esses gráficos mostram o erro na saída da rede neural, durante o treinamento, em função do número de iterações, para os três níveis. Na Figura 5.38 são apresentados os gráficos da convergência correspondentes ao primeiro conjunto de treinamento, e na Figura 5.39 os gráficos correspondentes ao segundo conjunto.

Observando os gráficos de convergência do primeiro conjunto de treinamento, Figura 5.38, combinações 1, 5 e 7, nota-se uma queda abrupta do erro do treinamento antes de 1000 iterações, nos três níveis. Na combinação 1, o erro de treinamento permanece quase constante a partir da iteração 2000, no nível 1; e nos níveis 2 e 3, o erro tende a permanecer quase constante depois da iteração 5500. Nas combinações 5 e 7, o erro permanece quase constante a partir das iterações 3500 e 1500, respectivamente, nos três níveis. As redes neurais tendem a convergir, na combinação 1 , em torno do erro de 0,0225 , no nível 1, e em torno de 0,021 a 0,022, nos níveis 2 e 3; na combinação 5 , em torno do erro de 0,005 , no nível 1, e em torno de 0,0075 , nos níveis 2 e 3 ; e na combinação 7 , em torno do erro de 0,0025 , nos três níveis. 

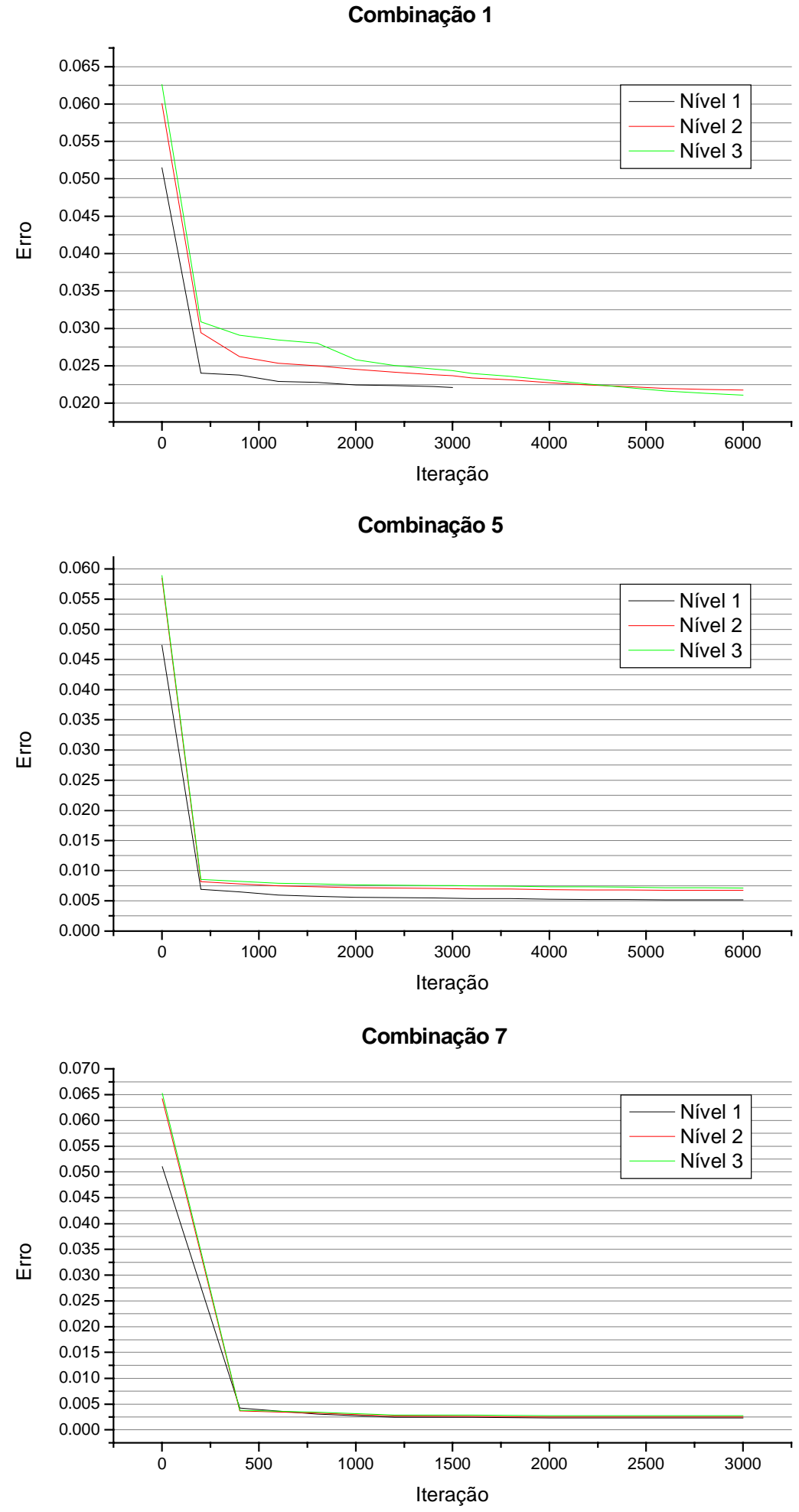

Figura 5.38 Convergência do treinamento das ANNs, primeiro conjunto. 


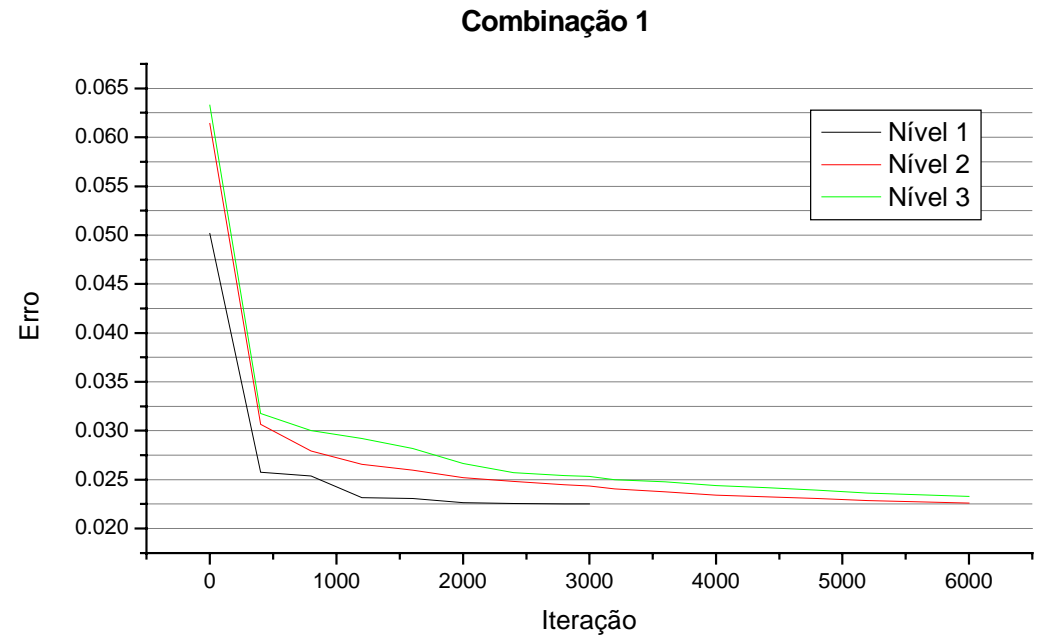

Combinação 5
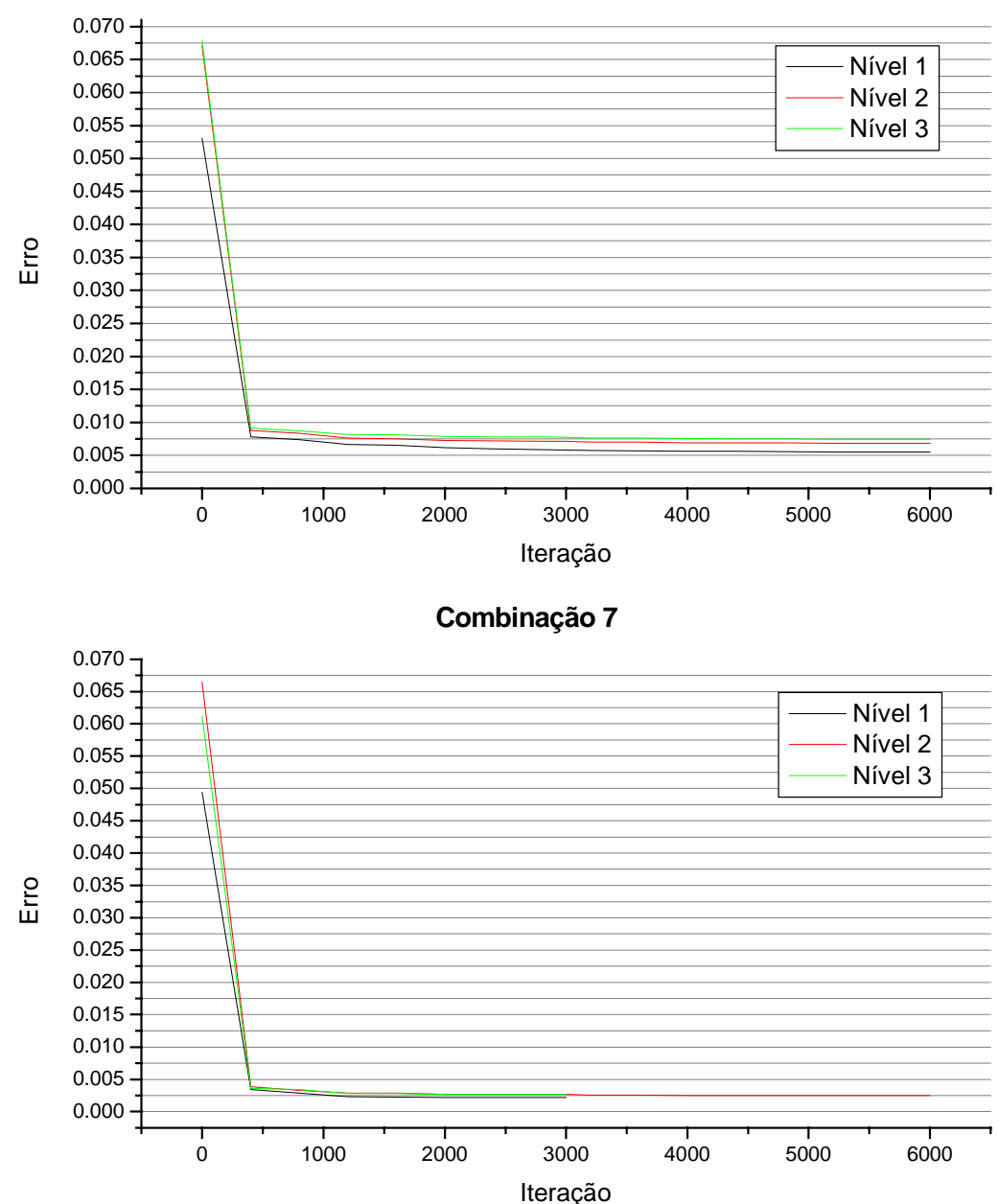

Figura 5.39 Convergência do treinamento das ANNs, segundo conjunto. 
Nos gráficos de convergência do segundo conjunto de treinamento, Figura 5.39, combinações 1, 5 e 7, observa-se, também, uma queda abrupta do erro de treinamento antes de 1000 iterações, nos 3 níveis. Na combinação 1, no nível 1, o erro de treinamento permanece quase constante a partir da iteração 2300, e nos níveis 2 e 3, o erro começa a permanecer quase constante, depois da iteração 5500. Nas combinações 5 e 7, o erro de treinamento permanece quase constante, após de 3500 e 2000 iterações, respectivamente, nos três níveis. As redes neurais tendem a convergir, na combinação 1 , nos níveis 1 e 2 , em torno do erro de 0,0225 , e no nível 3, em torno de 0,0235 ; na combinação 5, no nível 1 , em torno de 0,005 , e nos níveis 2 e 3, em torno de 0,0075 ; e na combinação 7 , em torno de 0,0025 , nos 3 níveis.

Em resumo, tanto no primeiro como no segundo conjunto de treinamento, nos três níveis, as redes neurais tendem a convergir, na combinação 1, em torno do erro de 0,020 a 0,0235; na combinação 5, em torno do erro de 0,005 a 0,0075; e na combinação 7, em torno do erro de 0,0025. A tolerância, utilizada nos treinamentos das combinações apresentadas foi de 0,001. Portanto, a combinação 7 é a que mais se aproxima da tolerância definida, seguida pela combinação 5, e a combinação 1 é a que menos se aproxima. A convergência das ANNs apresentadas corroboram, mais uma vez, que o primeiro grupo de combinações apresenta o pior desempenho, o segundo grupo apresenta um desempenho significativamente melhor que o primeiro grupo, e o terceiro grupo mostra o melhor desempenho.

\section{f) Tempo de treinamento e teste}

Os tempos de treinamento nesta fase foram maiores que na primeira fase, devido principalmente ao número de vetores de treinamento. Por exemplo, para o primeiro conjunto de treinamento, para as combinações 1, 5 e 7, o tempo de treinamento da rede neural foi de aproximadamente 15,38 e 12 minutos, respectivamente. Para o segundo conjunto de treinamento, também para as combinações 1, 5 e 7, o tempo de treinamento da rede neural foi de aproximadamente 18, 24 e 15 minutos respectivamente. 


\subsubsection{Considerações finais}

Ao realizar a análise dos dados coletados, item 5.1.1, observou-se que a fotossíntese apresentava características diferentes em cada estação. $O$ horário em que as plântulas começam a realizar fotossíntese, o horário dos valores máximos de fotossíntese, entre outros, varia em cada estação. Essas variações induziram a pensar que, talvez, ao treinar as redes neurais com os dados das 4 estações, o erro aumentaria. Os resultados mostram que o erro não aumenta. O desempenho das redes neurais treinadas na segunda fase da modelagem foi similar ao desempenho das redes neurais treinadas na primeira fase da modelagem. $\mathrm{O}$ erro relativo médio, o desvio padrão e o erro relativo máximo apresentados pelas redes neurais treinadas com os dados das 4 estações mostram valores próximos aos valores obtidos pelas redes neurais, com os dados separados por estações. Como exemplo, na Tabela 5.28 são mostrados o erro relativo médio, o desvio padrão e o erro relativo máximo, dos treinamentos com os dados de cada uma das estações (outono, inverno, primavera e verão) e com os dados das 4 estações, correspondentes ao segundo conjunto de treinamento, ao nível 1, e à combinação 11. A combinação 11 foi nomeada como combinação 7, na segunda fase da modelagem (observar Tabela 5.11 e Tabela 5.23, combinações de variáveis de entrada da primeira e segunda fase, respectivamente).

Tabela 5.28 - Comparação dos resultados dos treinamentos, da primeira fase com a segunda fase, correspondentes ao segundo conjunto de treinamento, ao nível 1, e à combinação 11 .

\begin{tabular}{|l|c|c|c|}
\hline $\begin{array}{l}\text { Treinamento } \\
\text { com os de dados }\end{array}$ & $\begin{array}{c}\text { Erro relativo } \\
\text { médio }\end{array}$ & Desvio padrão & $\begin{array}{c}\text { Erro relativo } \\
\text { máximo }\end{array}$ \\
\hline Do outono & 0.09857 & 0.12265 & 0.90110 \\
\hline Do inverno & 0.07348 & 0.10553 & 0.70140 \\
\hline Da primavera & 0.07360 & 0.08643 & 0.57845 \\
\hline Do verão & 0.08351 & 0.09351 & 0.78935 \\
\hline Das 4 estações & 0.08105 & 0.09850 & 0.82095 \\
\hline
\end{tabular}


Foram realizados treinamentos de redes neurais com dez combinações de variáveis de entrada, nas quais foi incluída a variável estação, para saber se a presença de uma variável que identifique a estação na qual foi realizada a medida melhorava ou não o desempenho das redes neurais. Os resultados indicam que a variável estação não influi na melhora do desempenho das ANNs. Isso mostra que a rede neural teve a capacidade de generalizar, sem a necessidade de identificar a estação na qual foi realizada a medida.

Em geral, a análise dos resultados dos treinamentos, na segunda fase da modelagem, mostra as mesmas características que a análise da primeira fase, no referente à influência das variáveis de entrada, aos resultados do primeiro e segundo conjunto de treinamento, e aos resultados do teste. 


\section{CONSIDERAÇÕES FINAIS}

\subsection{Conclusões}

\subsubsection{Fitomonitoração}

A fitomonitoração, realizada em plântulas de jatobá durante o período de um ano, duas vezes por semana, de 6 a 18 horas, e em três níveis das plântulas (partes inferior, média e superior), proporcionou uma quantidade de dados valiosa e inédita. Esta quantidade permitiu realizar tanto a análise do comportamento das variáveis fisiológicas e das variáveis ambientais como a modelagem de fotossíntese.

Os resultados da fitomonitoração mostraram características importantes tanto do comportamento das variáveis fisiológicas fotossíntese, transpiração, condutância estomática, fluorescência e temperatura da folha em jatobá, como do comportamento das variáveis ambientais concentração de $\mathrm{CO}_{2}$, umidade relativa, radiação fotossintética ativa e temperatura do ar, em cada uma das quatro estações do ano e nos três níveis das plântulas onde se realizaram as medidas.

Os resultados da análise do ciclo diário de fotossíntese nas plântulas de jatobá mostraram que este processo começa mais tarde nas estações do outono e do inverno, e mais cedo na primavera e no verão. A estação que apresentou os maiores valores foi a primavera, mas o maior período de fotossíntese ocorreu no verão. Os valores de fotossíntese foram similares nos três níveis das plântulas no outono e no inverno. $\mathrm{Na}$ primavera e no verão, os valores de fotossíntese do nível inferior foram menores, isto porque, possivelmente, as plântulas cresceram e se ramificaram, e, conseqüentemente, as folhas do nível inferior recebiam menor radiação, além de estarem senescentes em comparação com as folhas do nível superior. 
A análise dos resultados das medidas de taxa de fotossíntese, taxa de transpiração e condutância estomática mostraram que estas variáveis estão relacionadas diretamente. Quanto maior a condutância estomática, maior a fotossíntese, e quanto menor a fotossíntese, menor a condutância; a mesma relação foi observada entre a condutância e a transpiração. A relação que existe entre estas variáveis foi notória no verão; nesta estação houve a menor condutância estomática máxima, a menor transpiração máxima e a menor fotossíntese máxima. Isto ocorre possivelmente, porque as plântulas fecharam seus estômatos para evitar a perda de água, o que implicou menor transpiração, menor ingresso de $\mathrm{CO}_{2}$, e, conseqüentemente, menor fotossíntese. Estes resultados verificaram tanto o controle da transpiração como a regulação de entrada de $\mathrm{CO}_{2}$ na folha através dos estômatos e a influência das estações do ano (fatores ambientais) nessas variáveis fisiológicas.

As variáveis ambientais concentração de $\mathrm{CO}_{2}$ e umidade relativa mostraram um ciclo diário com valores maiores no começo e no fim do dia, e menores no transcurso do dia. Os maiores valores de concentração de $\mathrm{CO}_{2}$ foram verificados no outono e os menores valores no verão. Vale a pena salientar que o verão apresentou os menores valores máximos de fotossíntese e também apresentou os menores valores máximos de concentração de $\mathrm{CO}_{2}$. Os maiores valores máximos de umidade foram verificados no outono e os menores no verão; esta característica possivelmente esteja relacionada com a casa de vegetação onde estavam outras plantas além das plântulas de jatobá, as quais eram regadas continuamente.

A radiação fotossintética ativa (PAR) teve um comportamento similar ao da fotossíntese nos três níveis das plântulas. A radiação PAR foi maior no outono, mas por um período curto (11 a 12h) e esses valores ocorreram apenas em alguns dias. $\mathrm{Na}$ realidade, na primavera foram atingidos os maiores valores das 8 a 10 horas. $\mathrm{O}$ verão apresentou menores valores máximos, mas o período de radiação é maior, de 8 a 13 horas. Comparando a radiação PARi e a fotossíntese se observou que as quedas de radiação no inverno e na primavera (14 horas) e no verão (15 horas) influíram na fotossíntese, causando sua diminuição nesses horários. Outra evidência dessa 
influência é que no verão houve o maior período de radiação e o maior período de fotossíntese.

\subsubsection{Modelagem de fotossíntese com redes neurais artificiais}

O ciclo diário de fotossíntese, no nível da folha, foi modelado em função de 6 a 11 variáveis independentes, às quais a fotossíntese responde não linearmente, 8 das quais variam com o tempo e as condições ambientais. A técnica utilizada foi a de redes neurais artificiais. O modelo foi o multilayer perceptron com algoritmo de treinamento backpropagation, por ser o mais utilizado para propósitos de interpolação (modelagem). Os resultados obtidos mostraram que as redes neurais respondem satisfatoriamente à modelagem de fotossíntese.

A modelagem foi dividida em duas fases: primeira fase, modelagem da fotossíntese por estações, e segunda fase, modelagem da fotossíntese por ano. Essa divisão foi realizada para observar se as estações influíam na modelagem. Nas duas fases a modelagem foi realizada para cada um dos três níveis das plântulas, com o propósito de observar a influência dos níveis na modelagem.

Os dados coletados na fitomonitoração foram utilizados para realizar a interpolação. Os dados de entrada à rede foram as variáveis ambientais, além das variáveis temperatura da folha, tempo, planta e estação, e o dado de saída foi a fotossíntese. Para realizar os treinamentos foram definidas diferentes combinações de variáveis de entrada, 18 combinações para a primeira fase e 10 para a segunda fase, com o intuito de observar a influência de cada uma das variáveis ambientais, porém, com quais se obtinham os melhores resultados.

Realizados os primeiros treinamentos, foi observado que os valores de fotossíntese, medidos na faixa de $-0,099$ a $0,099 \mu \mathrm{mol} \mathrm{CO}_{2} \cdot \mathrm{m}^{-2} \cdot \mathrm{s}^{-1}$, influíam significativamente nos resultados dos treinamentos das ANNs. Esses valores estão relacionados com o erro de calibração do medidor portátil de fotossíntese. Como esse erro já estava implícito nos dados coletados, foram realizados dois conjuntos de 
treinamentos: um primeiro conjunto de treinamento com todos os dados, e um segundo conjunto de treinamento com os dados filtrados (sem os valores de fotossíntese na faixa de $-0,099$ a $0,099 \mu \mathrm{mol} \mathrm{CO}_{2} \cdot \mathrm{m}^{-2} \cdot \mathrm{s}^{-1}$ ), para observar a diferença entre os dois conjuntos de treinamento no desempenho das ANNs.

O método de tentativa e erro foi utilizado para encontrar o número adequado de neurônios para a camada escondida e os valores adequados para os parâmetros. Inicialmente foram definidas 21 variações ( 21 casos) na arquitetura e nos parâmetros da rede, para realizar treinamentos com os dados do outono, nível 1 das plântulas. Observando os resultados desses 21 casos foram selecionados 5 casos para a primeira fases da modelagem e 4 casos para a segunda fase da modelagem, para continuar realizando os treinamentos para os outros níveis, e para as outras estações (no caso da primeira fase). Na primeira fase da modelagem foram realizados aproximadamente 2320 treinamentos, e na segunda fase aproximadamente 270 treinamentos.

A análise dos resultados dos treinamentos compreendeu: a influência das combinações das variáveis de entrada no desempenho das ANNs, resultados do primeiro e segundo conjunto de treinamento, resultados por estação (no caso da primeira fase) e por nível na planta, teste das ANNs, convergência das ANNs e tempo de treinamento e teste.

Uma parte importante foi a análise da influência das variáveis baseada no erro. Essa análise mostrou a formação de três grupos de combinações de variáveis: o primeiro grupo de combinações apresentou os maiores erros, (em torno de 140\% para os treinamentos com todos os dados, e de $50 \%$ para os treinamentos com os dados filtrados); o segundo grupo apresentou erros menores (aproximadamente 65\% para os treinamentos com todos os dados, e $20 \%$ para os treinamentos com os dados filtrados); o terceiro grupo apresentou os menores erros (em torno de $25 \%$ para os treinamentos com todos os dados, e $8 \%$ para os treinamentos como os dados filtrados). Isto foi devido à influência significativa das variáveis concentração de $\mathrm{CO}_{2}$ do ar e da câmara e à influência das variáveis umidade relativa do ar e da 
câmara. No primeiro grupo não estiveram presentes as duas variáveis de concentração de $\mathrm{CO}_{2}$, do ar e da câmara. No segundo grupo estiveram as duas variáveis de concentração de $\mathrm{CO}_{2}$, do ar e da câmara, mas só uma das variáveis de umidade relativa, do ar ou da câmara. No terceiro grupo estiveram presentes as duas variáveis de concentração de $\mathrm{CO}_{2}$, do ar e da câmara, e as duas variáveis de umidade relativa, do ar e da câmara. Isto indica que a diferença de $\mathrm{CO}_{2}$ entre o ar e a câmara, ou seja, o $\mathrm{CO}_{2}$ que ingressa na folha influi significativamente. De igual maneira a diferença de umidade relativa entre o ar e a câmara influi; esta influência possivelmente seja devida à transpiração, já que a umidade na câmara é afetada pela transpiração. A análise mostra que a influência das outras variáveis não foi significativa; entre essas variáveis está a radiação ativa fotossintética (PAR) que se suponha influiria significativamente na fotossíntese. Mas observando os resultados não se notou essa influência.

A primeira combinação proposta, e desejada, para modelar fotossíntese, foi a combinação 1 , formada pelas variáveis concentração de $\mathrm{CO}_{2}$ do ar, umidade relativa do ar, radiação fotossintética ativa, medida dentro da câmara da folha (PARi), temperatura do ar, temperatura da folha e instante da medida (tempo). Desejava-se modelar fotossíntese com as variáveis ambientais medidas no ar, fora da câmara; exceto PARi, que é a radiação que chega na folha que está sendo medida. Os resultados mostraram que com essa combinação não se obtêm resultados bons.

O segundo objeto de análise foi o relacionado aos conjuntos de treinamento. Essa análise mostrou que o primeiro conjunto de treinamento (com todos os dados) apresenta erros significativamente maiores que o segundo conjunto (sem os dados na faixa de -0.099 a $\left.0,099 \mu \mathrm{mol} \mathrm{CO}_{2} \cdot \mathrm{m}^{-2} \cdot \mathrm{s}^{-1}\right)$. Por exemplo, no inverno, no nível 3 das plântulas, o erro caiu de $129 \%$ para $34 \%$ (primeiro grupo de combinações), de $56 \%$ para $14 \%$ (segundo grupo de combinações) e de $21 \%$ para $6 \%$ (terceiro grupo de combinações). Isto indica a grande influência dos valores de fotossíntese na faixa de -0.099 a 0,099 $\mu \mathrm{mol} \mathrm{CO}_{2} \cdot \mathrm{m}^{-2} \cdot \mathrm{s}^{-1}$, relacionados com a calibração do medidor de fotossíntese, nos resultados dos treinamentos. Isso mostra a grande influência do 
método e dos equipamentos de medida, particularmente na faixa de valores baixos, e a necessidade de se trabalhar nessa área.

O terceiro aspecto de análise foi a influência das estações e dos níveis da planta nos resultados dos treinamentos das ANNs. Essa análise mostrou que o desempenho das redes neurais foi melhor com os dados das estações do inverno e do outono, no primeiro conjunto de treinamento, e com os dados das estações do inverno e do verão, no segundo conjunto de treinamento. Não foi possível estabelecer uma relação sazonal desse desempenho com algum fator. No que se refere ao treinamento com os dados por níveis das plântulas, o desempenho das redes, em geral, foi similar nos três níveis.

O quarto objeto de análise foi a avaliação das redes neurais artificiais, ou seja, como foi a resposta das redes treinadas, a dados de entrada que não lhe foram fornecidos durante o treinamento. A análise dos resultados do teste das ANNs mostrou que as redes neurais treinadas tiveram boa capacidade de generalização. Os melhores resultados foram apresentados no terceiro grupo de combinações. O segundo grupo de combinações mostrou também bons resultados, mas em menor grau que o terceiro grupo. Os resultados do primeiro grupo de combinações mostraram a maior diferença de erro, o qual é aceitável porque esse grupo apresentou os maiores erros nos treinamentos. Comparando o teste do primeiro e do segundo conjunto de treinamento, como era de se esperar, o teste do primeiro conjunto apresentou maiores erros que o segundo conjunto. Por exemplo, o segundo conjunto apresentou uma diferença de erro (erro do teste - erro do treinamento) menor que 3\%, no terceiro grupo de combinações; menor que 5\%, no segundo grupo; e menor que $15 \%$, no primeiro grupo de combinações.

O quinto aspecto de análise foi a convergência do treinamento das ANNs, relacionado com o número de iterações e com a tolerância de erro. A análise nos dois conjuntos de treinamento mostrou, em geral, que o erro de treinamento começa a permanecer quase constante após um número de iterações entre 5000 a 5500, para o primeiro grupo de combinações e após um número de iterações entre 2000 a 3500, 
para o segundo e o terceiro grupos de combinações. A convergência das redes foi em torno do erro de 0,02 a 0,035 , no primeiro grupo de combinações, em torno de 0,005 a 0,01, no segundo grupo de combinações, e em torno de 0,002 a 0,005 , no terceiro grupo de combinações. Isto mostrou que o primeiro grupo de combinações foi o que menos se aproximou das tolerâncias definidas $(0,01$ e 0,001$)$, e que o terceiro grupo foi o que mais se aproximou da tolerância 0,001. Isso corrobora o comportamento dos três grupos de combinações de variáveis.

O sexto objeto de análise foi o relacionado com o tempo de treinamento, o qual dependeu de diferentes fatores, da combinação das variáveis de entrada, da estrutura da rede, dos parâmetros de treinamento, do computador utilizado, do número de vetores de treinamento, entre outros. Em geral, na primeira fase (treinamento por estação) o tempo de treinamento foi em torno de 8 a 9 minutos, para o primeiro conjunto de treinamento, e em torno de 5 minutos para o segundo conjunto. Na segunda fase (treinamento por ano) o tempo foi em torno de 12 a 38 minutos, para o primeiro conjunto de treinamento, e de 15 a 24 minutos para o segundo conjunto.

Finalmente, comparando os resultados da primeira e segunda fase da modelagem observou-se que o desempenho das redes neurais foi similar. Isto é, os erros apresentados pelas redes neurais treinadas em ambas fases mostraram valores próximos, o que indica que as estações não influíram no treinamento com os dados das quatro estações, mostrando assim que a rede teve uma boa capacidade de generalização.

\subsection{Contribuições}

Este trabalho apresenta contribuição tanto em nível metodológico como do ponto de vista de seus resultados.

Uma primeira contribuição é a proposta e desenvolvimento de um método para realizar fitomonitoração e modelagem de fotossíntese, na escala da folha, 
utilizando a técnica de redes neurais artificiais. O método aplicado em jatobá se mostrou adequado, e bastante promissor visando outros trabalhos na quantificação de $\mathrm{CO}_{2}$.

Uma segunda contribuição é a coleta de dados fisiológicos e ambientais numa grande quantidade, inédita pelo menos para o jatobá, durante o período de um ano. Essa quantidade de dados permitiu atingir os objetivos desta pesquisa e permitirá realizar outros trabalhos, explorando outros aspectos e relações. As medidas in situ de variáveis fisiológicas, tais como fotossíntese e transpiração, são complicadas, os instrumentos de medida para este propósito utilizam câmaras, o que implica em realizar as medidas em tempos curtos (em torno de 2 ou 3 minutos) para não afetar os órgãos da planta e não criar um microclima. Eles requerem a presença permanente de uma pessoa durante a coleta de dados. Isto é uma das dificuldades que se tem para coletar dados fisiológicos, como a fotossíntese, com uma maior freqüência.

Uma terceira contribuição é relacionada com o comportamento das variáveis fisiológicas do jatobá: fotossíntese, transpiração, condutância estomática, temperatura da folha e fluorescência, nas quatro estações do ano, assim como também o comportamento das variáveis ambientais em seu entorno, em casa de vegetação.

Uma quarta contribuição é a identificação de valores de fotossíntese na faixa de -0,099 a 0,099 $\mu \mathrm{mol} \mathrm{CO}_{2} \cdot \mathrm{m}^{-2} \cdot \mathrm{s}^{-1}$, relacionados com o erro de calibração do medidor de fotossíntese, que influem significativamente nos resultados dos treinamentos.

Uma quinta contribuição é relacionada com a identificação do grupo de variáveis de entrada que influem no bom desempenho das redes neurais.

Uma sexta contribuição é a identificação do número adequado de camadas escondidas e de neurônios para cada camada escondida, e os valores adequados para os parâmetros. 
Uma sétima contribuição é a verificação que o conjunto de variáveis de entrada (concentração de $\mathrm{CO}_{2}$ do ar, umidade relativa do ar, PARi, temperatura do ar, temperatura da folha e tempo), proposto inicialmente, não apresenta bons resultados nos treinamentos, e que no método proposto é imprescindível a presença das variáveis concentração de $\mathrm{CO}_{2}$, do ar e da câmara.

E uma oitava contribuição é relacionada com a influência das estações e os níveis das plantas, no desempenho das redes neurais. Verificou-se que essas variáveis não influem significativamente nos resultados dos treinamentos, o que mostra a boa capacidade de generalização da rede.

\subsection{Perspectivas}

Além das contribuições já apontadas, este trabalho permitiu identificar diversas outras possibilidades, demandas de trabalhos futuros e novos caminhos de pesquisa. Os seguintes pontos podem ser mencionados:

A. Trabalhos que podem ser explorados com os dados coletados

- A análise das variáveis fisiológicas em função das variáveis ambientais poderá revelar informações. Os gráficos relacionando essas variáveis já foram elaborados e deveram ser analisados.

- Outras técnicas, tais como a análise multivariável, podem ser utilizadas para permitir uma comparação e para extrair novas informações.

- Utilizando-se o método proposto neste trabalho, pode-se modelar o ciclo diário de fotossíntese com os dados das quatro estações e dos três níveis das plântulas simultaneamente. Pode-se também modelar o ciclo diário de condutância estomática e transpiração.

- Os dados coletados podem ser utilizados também para realizar previsão (forecasting) de fotossíntese, além das outras variáveis fisiológicas e ambientais medidas nesta pesquisa, usando também redes neurais. 
- Pode-se utilizar o toolbox de ANNs do Matlab para treinar as redes neurais com os dados coletados, e comparar com os resultados obtidos com o uso do programa MLP1b.

- Os dados coletados também podem ser úteis para a aplicação de outras técnicas da inteligência artificial, tais como algoritmos genéticos ou neurofuzzy, na modelagem de fotossíntese.

B. Outros assuntos de pesquisa a serem explorados

- Neste trabalho se sentiu a necessidade de utilizar outros instrumentos para realizar medidas de fotossíntese. Isso pode ser uma motivação para se pesquisar novos sensores para medir $\mathrm{CO}_{2}$ na planta.

- A quantificação da fixação de $\mathrm{CO}_{2}$ em plântulas de jatobá, pode-se basear neste método, em futuros experimentos.

- Outro assunto de pesquisa é a extrapolação da modelagem de fotossíntese da escala da folha para a escala da planta.

Este trabalho abriu um novo tema de pesquisa no Laboratório de Automação Agrícola, dentro de uma parceria bastante produtiva com o Instituto de Botânica. No futuro outros trabalhos poderão ser desenvolvidos com o Instituto de Botânica e outras instituições. 


\section{BIBLIOGRAFIA}

Anderson, M. C.; Norman, J. M.; Meyers, T. P. and Diak, G. R. An analytical model for estimating canopy transpiration and carbon assimilation fluxes based on canopy light-use efficiency, Agricultural and Forest Meteorology, Vol. 101, 4, 2000, pp 265-289.

Baratto, G. Classificador de aromas com redes neurais artificiais para um nariz eletrônico, Tese de doutorado, Universidade de São Paulo, 1998.

Baratto, G.; Ramirez-Fernandez, F.J. Signal reconstruction of tin oxide sensors with a neural network, XIII SBMicro - International Conference on Microelectronics and Packaging - ICMP'98, 12-14 Agosto, 1998, pp.102-109 Curitiba, PR.

Basheer, I. A.; Hajmeer, M. Artificial neural networks: fundamentals, computing, design, and application, Journal of Microbiological Methods, Vol 43, 2000, pp.331.

Betto, F. Rio+10=Johannesburgo, O ESTADO DE S. PAULO, 21 ago. 2002, Pesquisa. Disponível em: URL: http://www.estado.estadao.com.br/jornal/02/08/21/news245.html. [Acesso em 06/04/03].

Boegh, E.; Soegaard, H.; Friborg, T. and Levy, P. E. Models of $\mathrm{CO}_{2}$ and water vapour fluxes from a sparse millet crop in the Sahel, Agricultural and Forest Meteorology, Vol. 93, 1, 1999, pp 7-26.

Canadell, J.; Mooney, H. A. Ecosystem metabolism and the global carbon cycle, Trends in Ecology \& Evolution, Vol. 14, 6, 1999, p 249.

Chen, J. M.; Liu, J.; Cihlar, J. and Goulden, M. L. Daily canopy photosynthesis model through temporal and spatial scaling for remote sensing applications, Ecologic Modelling, Vol. 124, 2-3, 1999, pp 99-119. 
Fausett, L. Fundamentals of Neural Networks: architectures, algorithms, and applications, London, Prentice Hall International, 1994.

Friend, A. D. and Cox, P. M. Modelling the effects of atmospheric $\mathrm{CO}_{2}$ on vegetation-atmosphere interactions, Agricultural and Forest Meteorology, Vol. 73, 3-4, 1995, pp 285-295.

Fujisaka, S.; Castilla, C.; Escobar, G.; Rodrigues, V.; Veneklaas, E. J.; Thomas, R. and Fisher, M. The effects of forest conversion on annual crops and pastures: Estimates of carbon emissions and plant species loss in a Brazilian Amazon colony, Agriculture, Ecosystems \& Environment, Vol. 69, 1, 1998, pp 17-26.

Golubyatnikov, L. L.; Denisenko, E. A. and Svirezhev, Y. M. Model of the total exchange carbon flux for terrestrial ecosystems, Ecologic Modelling, Vol. 108, 13, 1998, pp 265-276.

Gross, L.; Thiria, S. and Frouin, R. Applying artificial neural network methodology to ocean color remote sensing, Ecologic Modelling, Vol. 120, 1999, pp 237-246.

Ham, J. M. and Knapp, A. K. Fluxes of $\mathrm{CO}_{2}$, water vapor, and energy from a prairie ecosystem during the seasonal transition from carbon sink to carbon source, Agricultural and Forest Meteorology, Vol. 89, 1, 1998, pp 1-14.

Hättenschwiler, S. Natural $\mathbf{C O}_{2}$ springs: obstacle or opportunity?, Trends in Ecology \& Evolution, Vol. 13, 9, 1998, pp 375-376.

Haykin, S. Neural networks: a comprehensive foundation, New Jersey, Macmillan Publishing Company, 1994.

Hertz, J.; Krogh, A.; Palmer, R. G. Introduction to the theory of Neural Computation, New York, Addison-Wesley Publishing Company, 1991.

Hu, S.; Firestone, M. K.; Chapin, F. S. Soil microbial feedbacks to atmospheric CO 2 enrichment, Trends in Ecology \& Evolution, Vol. 14, 11, 1999, pp 433-437. 
Huntingford, C. and Cox, P. M. Use of statistical and neural network techniques to detect how stomatal conductance responds to changes in the local environment, Ecologic Modelling, Vol. 97, 3, 1997, pp 217-246.

Infante, J. M.; Damesin, C.; Rambal, S. and Fernández-Alés, R. Modelling leaf gas exchange in holm-oak trees in southern Spain, Agricultural and Forest Meteorology, Vol. 95, 4, 1999, pp 203-223.

IPCC, Intergovernmental Panel on Climate Change An introduction to simple climate models used in the IPCC second Assessment Report - IPCC - Technical PaperII, 1997. Disponível em: URL: http://www.ufv.br/paper/gov.htm. [Acesso em 04/05/03].

Kellomäki, S. and Wang, K. -Y. Short-term environmental controls on carbon dioxide flux in a boreal coniferous forest: model computation compared with measurements by eddy covariance, Ecologic Modelling, Vol. 128, 1, 2000, pp 6388.

Korzukhin, M. D. and Ter-Mikaelian, M. T. An individual tree-based model of competition for light, Ecologic Modelling, Vol. 79, 1-3, 1995, pp 221-229.

Larcher, W. Physiological Plant Ecology. New York, Springer - Verlag Berling Heidelberg, Third Edi, 1995.

Laurance, W. F. A crisis in the making: responses of Amazonian forests to land use and climate change, Trends in Ecology \& Evolution, Vol. 13, 10, 1998, pp 411415 .

Laurance, W. F. and Fearnside, P. M. Amazon burning, Trends in Ecology \& Evolution, Vol. 14, 11, 1999, p 457.

LeBlanc, A. Issues related to including forestry-based offsets in a GHG emissions trading system, Environmental Science \& Policy, Vol. 2, 1999, pp 199206.

Lek, S. and Guégan J. F. Artificial neural networks as a tool in ecological modelling, an introduction, Ecologic Modelling, Vol. 120, 2-3, 1999, pp 65-73. 
LI-COR, Using the LI-3000A leaf area meter, USA, 1998.

LI-COR, Using the LI-6400 portable photosynthesis system, USA, 1999.

Lim, B.; Brown, S.; Schlamadinger, B. Carbon accounting for forest harvesting and wood products: review and evaluation of different approaches, Environmental Science \& Policy, Vol. 2, 1999, pp 207-216.

Lorenzi, H. Arvores brasileiras: manual de identificação e cultivo de plantas arbóreas nativas do Brasil, Editora Plantarum, 1992.

Loureiro, M. E.; Martinez, C. Fotossíntese, Material didático de apoio à disciplina BVE 270, 2002. Disponível em: URL: http://www.ufv.br/paper/gov.htm. [Acesso em 03/07/03].

Marland, G.; Schlamadinger, B. The Kyoto protocol could make a difference for the optimal forest-based $\mathrm{CO}_{2}$ mitigation strategy: some results from GORCAM, Environmental Science \& Policy, Vol. 2, 1999, pp 111-124.

Mudrik, V. A.; Romanova, A. K.; Ivanov, B. N.; Novichkova, N. S.; Polyakova, V. A. Effect of increased $\mathrm{CO}_{2}$ concentration on growth, photosynthesis, and composition of Pisum sativum L. plants, Russian Journal of Plant Physiology, Vol. 44, No 2, 1997, pp 141-146.

OPTI-SCIENCES, OS5-FL Modulated Chlorophyll fluorometer operation manual, USA, 1998.

Patterson, D. W. Artifcial neural network: theory and application, Singapore, Prentice Hall, 1996.

Piveta, M. Pouco gás na floresta amazônica Revista Pesquisa FAPESP, Ed. 72, 2002. Suplemento. Disponível em: URL: http://revistapesquisa.fapesp.br [Acesso em 04/03/03].

Puente de la Vega, M.B.; Lisboa - Perez, M.; Ramirez - Fernandez, F. J.; Baratto, G. Enhanced Selectivity of Sensors Array for Brazilian Brandy Classification, Computational Intelligent And Applications, Estados Unidos, v.1, 1999, p.393-398. 
Raven, P. H.; Eichorn, S. E.; Evert, R. F. Biologia Vegetal, 5. ed., Rio de Janeiro: Guanabara, 1992.

Roberts, D. W. Landscape vegetation modelling with vital attributes and fuzzy systems theory, Ecologic Modelling, Vol. 90, 2, 1996b, pp 175-184.

Roberts, D. W. Modelling forest dynamics with vital attributes and fuzzy systems theory, Ecologic Modelling, Vol. 90, 2, 1996a, pp 161-173.

RVD, Revista Plantio Direto, Seqüestro de Carbono, edição 55, janeiro/fevereiro de 2000 .

Silvert, W. Ecological impact classification with fuzzy sets, Ecologic Modelling, Vol. 96, 1-3, 1997, pp 1-10.

UniSci Science, Coral Reefs To Be First Casualty of CO2 Emissions, abril 1999.

Van Wijk, M. T. and Bouten, W. Water and carbon fluxes above European coniferous forests modelled with artificial neural networks, Ecologic Modelling, Vol. 120, 2-3, 1999, pp 181-197.

Walsh, M. J. Maximizing financial support for biodiversity in the emerging Kyoto protocol markets, The Science of the Total Environmental, Vol. 240, 1999, pp 145-156.

Ward, J. K.; Strain, B. R. Elevated $\mathrm{CO}_{2}$ studies: Past, present and future, Tree Physiology, Vol. 19, 4-5, 1999, pp 211-220.

Wasserman, P. D. Neural Computing Theory and Practice. New York, Van Nostrand Reinhold, 1989.

White, A.; Cannell, M. G. R.; Friend, A. D. Climate change impacts on ecosystems and the terrestrial carbon sink: a new assessment, Global Environmental Change, Vol. 9, 99, 1999, pp S21-S30.

Wohlfahrt, G.; Bahn, M.; Tappeiner, U. and Cernusca A. A model of whole plant gas exchange for herbaceous species from mountain grassland sites differing in land use, Ecologic Modelling, Vol. 125, 2-3, 2000, pp 173-201. 
Wook, K. J. and Kim, J. H. Modelling the net photosynthetic rate of Quercus mongolica stands affected by ambient ozone, Ecologic Modelling, Vol. 97, 3, 1997, pp 167-177.

Zhang, G.; Patuwo, B. E.; Hu, M. Y. Forecasting with artificial neural network:

The state of the art, International journal of forescasting, Vol. 14, 1998, pp 35-62. 


\section{APÊNDICE A}

\section{RESULTADOS DOS TREINAMENTOS DA PRIMEIRA}

FASE DA MODELAGEM 
Tabela A.1 - Erros obtidos no treinamento, primeiro conjunto (com todos os dados), outono.

\begin{tabular}{|c|r|r|r|r|r|r|r|r|r|}
\hline \multirow{2}{*}{ Combinação } & \multicolumn{3}{|c|}{ Nível 1 } & \multicolumn{1}{c|}{ Nível 2 } & \multicolumn{2}{c|}{ Nível 3 } \\
\cline { 2 - 10 } & $\begin{array}{c}\text { Erro } \\
\text { relativo } \\
\text { médio }\end{array}$ & \multicolumn{1}{c|}{$\begin{array}{c}\text { Desvio } \\
\text { padrão }\end{array}$} & $\begin{array}{c}\text { Erro } \\
\text { relativo } \\
\text { máximo }\end{array}$ & $\begin{array}{c}\text { Erro } \\
\text { relativo } \\
\text { médio }\end{array}$ & $\begin{array}{c}\text { Desvio } \\
\text { padrão }\end{array}$ & $\begin{array}{c}\text { Erro } \\
\text { relativo } \\
\text { máximo }\end{array}$ & $\begin{array}{c}\text { Erro } \\
\text { relativo } \\
\text { médio }\end{array}$ & $\begin{array}{c}\text { Desvio } \\
\text { padrão }\end{array}$ & $\begin{array}{c}\text { Erro } \\
\text { relativo } \\
\text { máximo }\end{array}$ \\
\hline 1 & 1.24619 & 3.65383 & 46.01972 & 0.91085 & 2.23645 & 28.82328 & 0.8523 & 2.99026 & 44.80877 \\
\hline 2 & 1.30361 & 3.34995 & 40.12125 & 0.92898 & 2.48912 & 34.05153 & 0.88757 & 3.23769 & 48.91104 \\
\hline 3 & 1.25839 & 2.85137 & 27.05853 & 1.16321 & 2.85423 & 45.92448 & 1.00028 & 3.1055 & 41.91368 \\
\hline 4 & 1.29924 & 3.00525 & 31.21765 & 0.94498 & 2.472 & 34.5294 & 0.87084 & 2.5415 & 32.30594 \\
\hline 5 & 1.10746 & 2.17435 & 22.17945 & 1.02119 & 2.24927 & 30.66204 & 0.88281 & 2.96836 & 43.52412 \\
\hline 6 & 0.32447 & 0.71218 & 6.62631 & 0.39584 & 1.02101 & 11.70522 & 0.33504 & 1.05181 & 17.40565 \\
\hline 7 & 0.35289 & 0.79549 & 8.28885 & 0.45302 & 1.13259 & 11.35361 & 0.33628 & 1.12246 & 17.46249 \\
\hline 8 & 1.02419 & 3.03221 & 40.10844 & 0.80693 & 1.88773 & 22.65792 & 0.74013 & 2.62477 & 40.50066 \\
\hline 9 & 1.02502 & 3.00713 & 45.43917 & 0.74708 & 1.65685 & 20.01903 & 0.70538 & 2.4638 & 38.15928 \\
\hline 10 & 0.19977 & 0.39239 & 4.49899 & 0.22783 & 0.5123 & 5.40228 & 0.25276 & 0.75896 & 11.05755 \\
\hline 11 & 0.20446 & 0.37311 & 3.49937 & 0.23132 & 0.54372 & 5.44205 & 0.24549 & 0.94378 & 19.09701 \\
\hline 12 & 0.20771 & 0.4067 & 3.93137 & 0.25214 & 0.55077 & 4.7974 & 0.27114 & 0.85256 & 12.99116 \\
\hline 13 & 0.2174 & 0.40811 & 3.57985 & 0.26352 & 0.54453 & 5.24542 & 0.21595 & 0.65787 & 9.45834 \\
\hline 14 & 0.21796 & 0.40818 & 3.45339 & 0.20932 & 0.445 & 4.99774 & 0.21214 & 0.58999 & 7.66995 \\
\hline 15 & 0.31282 & 0.69043 & 7.47526 & 0.42659 & 1.06825 & 12.29524 & 0.30976 & 0.89125 & 11.67768 \\
\hline 16 & 0.30829 & 0.68149 & 6.79133 & 0.38759 & 1.01782 & 11.96308 & 0.28907 & 0.89378 & 14.62181 \\
\hline 17 & 0.20289 & 0.38352 & 3.15275 & 0.27871 & 0.61445 & 6.30411 & 0.28286 & 0.79677 & 9.5144 \\
\hline 18 & 0.23276 & 0.47322 & 5.21719 & 0.19894 & 0.46592 & 6.46691 & 0.25828 & 0.97792 & 19.68126 \\
\hline
\end{tabular}


Tabela A.2 - Erros obtidos no teste, primeiro conjunto (com todos os dados), outono.

\begin{tabular}{|c|c|c|c|c|c|c|c|c|c|}
\hline \multirow[t]{2}{*}{ Combinação } & \multicolumn{3}{|c|}{ Nível 1} & \multicolumn{3}{|c|}{ Nível 2} & \multicolumn{3}{|c|}{ Nível 3} \\
\hline & $\begin{array}{c}\text { Erro } \\
\text { relativo } \\
\text { médio }\end{array}$ & $\begin{array}{l}\text { Desvio } \\
\text { padrão }\end{array}$ & $\begin{array}{c}\text { Erro } \\
\text { relativo } \\
\text { máximo }\end{array}$ & $\begin{array}{c}\text { Erro } \\
\text { relativo } \\
\text { médio }\end{array}$ & $\begin{array}{l}\text { Desvio } \\
\text { padrão }\end{array}$ & $\begin{array}{c}\text { Erro } \\
\text { relativo } \\
\text { máximo }\end{array}$ & $\begin{array}{c}\text { Erro } \\
\text { relativo } \\
\text { médio }\end{array}$ & $\begin{array}{l}\text { Desvio } \\
\text { padrão }\end{array}$ & $\begin{array}{c}\text { Erro } \\
\text { relativo } \\
\text { máximo }\end{array}$ \\
\hline 1 & 1.20569 & 2.66578 & 22.7933 & 1.00788 & 1.58485 & 11.4307 & 0.98742 & 2.22391 & 22.15176 \\
\hline 2 & 1.53014 & 4.46153 & 44.7823 & 1.0651 & 2.25301 & 29.1841 & 0.99583 & 2.25655 & 19.51167 \\
\hline 3 & 1.34173 & 3.10386 & 28.5567 & 1.15589 & 2.20294 & 24.6974 & 1.0897 & 2.39615 & 18.25828 \\
\hline 4 & 1.23723 & 2.93427 & 26.9065 & 0.93969 & 1.50084 & 14.1663 & 0.92551 & 1.88193 & 21.07363 \\
\hline 5 & 2.00018 & 8.94008 & 136.98 & 0.99841 & 1.51932 & 14.1021 & 1.21148 & 2.54038 & 21.87434 \\
\hline 6 & 0.33725 & 0.86794 & 7.05895 & 0.39289 & 0.76855 & 7.63793 & 0.30216 & 0.62742 & 6.56103 \\
\hline 7 & 0.35121 & 0.89184 & 8.47477 & 0.49027 & 1.1177 & 10.6387 & 0.31755 & 0.70422 & 6.52962 \\
\hline 8 & 1.27889 & 3.19506 & 27.6049 & 0.85415 & 1.81593 & 25.06 & 0.85507 & 2.09797 & 21.96326 \\
\hline 9 & 1.51364 & 4.60299 & 41.1307 & 1.01283 & 2.1826 & 23.6341 & 0.77513 & 1.79063 & 16.83313 \\
\hline 10 & 0.26858 & 0.87136 & 9.00829 & 0.25626 & 0.61275 & 6.46081 & 0.29549 & 0.85138 & 9.53007 \\
\hline 11 & 0.25604 & 0.76366 & 7.37925 & 0.23751 & 0.52861 & 6.20799 & 0.27002 & 0.70771 & 8.55193 \\
\hline 12 & 0.24441 & 0.67654 & 6.45654 & 0.27056 & 0.5148 & 5.05871 & 0.32865 & 0.90807 & 9.67755 \\
\hline 13 & 0.26691 & 0.75837 & 7.79809 & 0.31451 & 0.63942 & 6.25837 & 0.2322 & 0.64141 & 7.16075 \\
\hline 14 & 0.26865 & 0.76613 & 7.66278 & 0.23948 & 0.53181 & 6.22719 & 0.23742 & 0.53939 & 4.95243 \\
\hline 15 & 0.3164 & 0.76128 & 7.20887 & 0.38499 & 0.77869 & 9.00954 & 0.30037 & 0.77775 & 10.22976 \\
\hline 16 & 0.34443 & 0.9267 & 9.85679 & 0.3732 & 0.68395 & 6.9623 & 0.32366 & 0.69317 & 6.48964 \\
\hline 17 & 0.25286 & 0.71116 & 6.38163 & 0.30599 & 0.60779 & 5.94097 & 0.35459 & 1.06948 & 13.19112 \\
\hline 18 & 0.24906 & 0.62473 & 6.52502 & 0.24312 & 0.45392 & 3.53395 & 0.32654 & 0.82277 & 8.23521 \\
\hline
\end{tabular}


Tabela A.3 - Erros obtidos no treinamento, primeiro conjunto (com todos os dados), inverno.

\begin{tabular}{|c|r|r|r|r|r|r|r|r|r|}
\hline \multirow{2}{*}{ Combinação } & \multicolumn{3}{|c|}{ Nível 1 } & \multicolumn{1}{c|}{ Nível 2 } & \multicolumn{2}{c|}{ Nível 3 } \\
\cline { 2 - 10 } & $\begin{array}{c}\text { Erro } \\
\text { relativo } \\
\text { médio }\end{array}$ & \multicolumn{1}{|c|}{$\begin{array}{c}\text { Desvio } \\
\text { padrão }\end{array}$} & $\begin{array}{c}\text { Erro } \\
\text { relativo } \\
\text { máximo }\end{array}$ & $\begin{array}{c}\text { Erro } \\
\text { relativo } \\
\text { médio }\end{array}$ & $\begin{array}{l}\text { Desvio } \\
\text { padrão }\end{array}$ & $\begin{array}{c}\text { Erro } \\
\text { relativo } \\
\text { máximo }\end{array}$ & $\begin{array}{l}\text { Erro } \\
\text { relativo } \\
\text { médio }\end{array}$ & $\begin{array}{c}\text { Desvio } \\
\text { padrão }\end{array}$ & $\begin{array}{c}\text { Erro } \\
\text { relativo } \\
\text { máximo }\end{array}$ \\
\hline 1 & 0.77155 & 2.06442 & 29.72372 & 0.82317 & 2.18686 & 33.99572 & 1.1962 & 6.21549 & 90.51962 \\
\hline 2 & 0.76272 & 2.04764 & 19.32882 & 0.80624 & 2.54605 & 48.29608 & 1.25516 & 8.22728 & 161.196 \\
\hline 3 & 0.69206 & 1.43537 & 16.03975 & 0.86605 & 1.96537 & 27.87677 & 1.58699 & 8.99867 & 160.59201 \\
\hline 4 & 0.88252 & 2.24914 & 29.88588 & 0.80159 & 3.34635 & 70.36515 & 1.19451 & 5.97962 & 89.19734 \\
\hline 5 & 0.779 & 2.00391 & 31.65353 & 0.80737 & 2.96533 & 57.79162 & 1.3556 & 7.44519 & 134.80471 \\
\hline 6 & 0.30556 & 0.86785 & 14.57271 & 0.39035 & 1.03337 & 16.01749 & 0.57482 & 3.50255 & 62.90938 \\
\hline 7 & 0.33503 & 0.92523 & 10.90799 & 0.3908 & 1.05427 & 15.86349 & 0.51776 & 2.73748 & 37.86192 \\
\hline 8 & 0.6839 & 1.73632 & 29.00794 & 0.67308 & 2.36063 & 49.76319 & 1.23355 & 7.66073 & 128.12809 \\
\hline 9 & 0.70708 & 1.84049 & 21.8696 & 0.74044 & 2.49817 & 52.29661 & 1.21331 & 7.25655 & 123.29389 \\
\hline 10 & 0.13078 & 0.41673 & 7.04313 & 0.19072 & 0.49871 & 4.35624 & 0.20494 & 1.47534 & 30.60876 \\
\hline 11 & 0.13172 & 0.39919 & 6.69412 & 0.17989 & 0.44317 & 3.90986 & 0.20558 & 1.28058 & 25.88462 \\
\hline 12 & 0.13486 & 0.41775 & 6.86494 & 0.18572 & 0.462 & 4.11509 & 0.20375 & 1.41069 & 28.68894 \\
\hline 13 & 0.13753 & 0.41194 & 6.20464 & 0.1827 & 0.44824 & 3.83498 & 0.20236 & 1.32996 & 26.14657 \\
\hline 14 & 0.13341 & 0.40408 & 6.43303 & 0.19911 & 0.49415 & 4.17729 & 0.22812 & 1.76058 & 37.31802 \\
\hline 15 & 0.28704 & 0.75695 & 11.30296 & 0.34756 & 0.9229 & 13.19256 & 0.55299 & 3.11199 & 55.45008 \\
\hline 16 & 0.28958 & 0.81204 & 13.8963 & 0.38443 & 1.00032 & 14.42704 & 0.58444 & 3.73099 & 70.5017 \\
\hline 17 & 0.13132 & 0.39359 & 6.56519 & 0.19426 & 0.47296 & 4.28921 & 0.2105 & 1.4193 & 29.07597 \\
\hline 18 & 0.15879 & 0.54124 & 9.3708 & 0.2075 & 0.50121 & 4.03756 & 0.1896 & 1.04663 & 18.38536 \\
\hline
\end{tabular}


Tabela A.4 - Erros obtidos no teste, primeiro conjunto (com todos os dados), inverno.

\begin{tabular}{|c|c|c|c|c|c|c|c|c|c|}
\hline \multirow[t]{2}{*}{ Combinação } & \multicolumn{3}{|c|}{ Nível 1} & \multicolumn{3}{|c|}{ Nível 2} & \multicolumn{3}{|c|}{ Nível 3} \\
\hline & $\begin{array}{c}\text { Erro } \\
\text { relativo } \\
\text { médio }\end{array}$ & $\begin{array}{l}\text { Desvio } \\
\text { padrão }\end{array}$ & $\begin{array}{c}\text { Erro } \\
\text { relativo } \\
\text { máximo }\end{array}$ & $\begin{array}{c}\text { Erro } \\
\text { relativo } \\
\text { médio } \\
\end{array}$ & $\begin{array}{l}\text { Desvio } \\
\text { padrão }\end{array}$ & $\begin{array}{c}\text { Erro } \\
\text { relativo } \\
\text { máximo }\end{array}$ & $\begin{array}{c}\text { Erro } \\
\text { relativo } \\
\text { médio } \\
\end{array}$ & $\begin{array}{l}\text { Desvio } \\
\text { padrão }\end{array}$ & $\begin{array}{c}\text { Erro } \\
\text { relativo } \\
\text { máximo }\end{array}$ \\
\hline 1 & 0.77305 & 1.53467 & 19.6792 & 1.05912 & 3.88474 & 42.0068 & 0.96223 & 3.27371 & 49.8429 \\
\hline 2 & 0.74271 & 1.42194 & 11.9001 & 1.01362 & 3.7783 & 47.4745 & 1.20223 & 4.85696 & 67.5945 \\
\hline 3 & 0.79857 & 1.58114 & 18.5395 & 1.44319 & 6.42525 & 90.3513 & 1.4114 & 6.01879 & 92.2411 \\
\hline 4 & 0.69594 & 1.28838 & 14.1927 & 0.95193 & 3.91257 & 64.0387 & 1.41888 & 8.84359 & 150.283 \\
\hline 5 & 0.8155 & 1.52944 & 14.3961 & 1.01837 & 3.08675 & 32.5064 & 1.13584 & 6.58179 & 113.658 \\
\hline 6 & 0.29814 & 0.95868 & 12.9369 & 0.39625 & 1.16608 & 13.6155 & 0.33727 & 1.04059 & 9.61962 \\
\hline 7 & 0.32277 & 0.98307 & 13.1613 & 0.37677 & 1.09203 & 13.5043 & 0.36779 & 1.70492 & 26.1762 \\
\hline 8 & 0.726 & 1.57189 & 19.7458 & 0.95264 & 3.79653 & 55.5318 & 1.09515 & 4.20029 & 59.1515 \\
\hline 9 & 0.80641 & 1.9443 & 21.7561 & 0.96168 & 4.13765 & 56.8087 & 1.00002 & 3.44557 & 40.6275 \\
\hline 10 & 0.14421 & 0.38925 & 5.55269 & 0.15135 & 0.44596 & 6.01041 & 0.17926 & 0.7777 & 10.219 \\
\hline 11 & 0.13428 & 0.25986 & 2.32388 & 0.14833 & 0.41648 & 4.7392 & 0.27888 & 2.00617 & 33.2037 \\
\hline 13 & 0.15677 & 0.53692 & 8.66256 & 0.14886 & 0.40434 & 4.59316 & 0.14485 & 0.53321 & 6.66044 \\
\hline 14 & 0.14311 & 0.40172 & 5.87544 & 0.14605 & 0.37766 & 3.79689 & 0.23024 & 1.16486 & 15.9509 \\
\hline 15 & 0.28895 & 0.84351 & 11.7591 & 0.43082 & 1.35084 & 13.7125 & 0.51118 & 2.81213 & 45.228 \\
\hline 16 & 0.30101 & 0.98902 & 13.8104 & 0.40657 & 1.1481 & 13.5385 & 0.3825 & 1.20855 & 12.6943 \\
\hline 17 & 0.15217 & 0.45959 & 7.21787 & 0.1496 & 0.37678 & 4.35214 & 0.16633 & 0.6009 & 5.49467 \\
\hline 18 & 0.17398 & 0.50647 & 7.73054 & 0.16959 & 0.48669 & 5.53669 & 0.20525 & 0.93544 & 13.4187 \\
\hline
\end{tabular}


Tabela A.5 - Erros obtidos no treinamento, primeiro conjunto (com todos os dados), primavera.

\begin{tabular}{|c|r|r|r|r|r|r|r|r|r|}
\hline \multirow{2}{*}{ Combinação } & \multicolumn{3}{|c|}{ Nível 1 } & \multicolumn{1}{c|}{ Nível 2 } & \multicolumn{2}{c|}{ Nível 3 } \\
\cline { 2 - 10 } & $\begin{array}{c}\text { Erro } \\
\text { relativo } \\
\text { médio }\end{array}$ & \multicolumn{1}{c|}{$\begin{array}{c}\text { Desvio } \\
\text { padrão }\end{array}$} & $\begin{array}{c}\text { Erro } \\
\text { relativo } \\
\text { máximo }\end{array}$ & $\begin{array}{c}\text { Erro } \\
\text { relativo } \\
\text { médio }\end{array}$ & $\begin{array}{c}\text { Desvio } \\
\text { padrão }\end{array}$ & $\begin{array}{c}\text { Erro } \\
\text { relativo } \\
\text { máximo }\end{array}$ & $\begin{array}{c}\text { Erro } \\
\text { relativo } \\
\text { médio }\end{array}$ & $\begin{array}{c}\text { Desvio } \\
\text { padrão }\end{array}$ & $\begin{array}{c}\text { Erro } \\
\text { relativo } \\
\text { máximo }\end{array}$ \\
\hline 1 & 1.22123 & 7.00457 & 148.63313 & 1.33776 & 6.10427 & 121.032 & 1.19574 & 6.15028 & 124.95288 \\
\hline 2 & 1.19691 & 6.04144 & 125.09264 & 1.20076 & 5.34561 & 104.48413 & 1.22993 & 5.09866 & 65.26519 \\
\hline 3 & 1.32973 & 8.45733 & 177.11636 & 1.39728 & 5.0119 & 83.64724 & 1.48114 & 5.52027 & 80.09452 \\
\hline 4 & 1.16437 & 5.66224 & 117.72013 & 1.16507 & 3.97431 & 58.22125 & 1.17292 & 5.0074 & 79.30283 \\
\hline 5 & 1.109 & 6.62193 & 141.2791 & 1.11494 & 3.77995 & 58.14611 & 1.27742 & 4.77363 & 53.66449 \\
\hline 6 & 0.50754 & 1.70139 & 22.45366 & 0.50573 & 1.64323 & 19.75916 & 1.48302 & 18.8263 & 413.43197 \\
\hline 7 & 0.60818 & 3.38226 & 67.10391 & 0.52332 & 1.80131 & 24.71896 & 0.936 & 6.9573 & 140.30056 \\
\hline 8 & 1.17645 & 5.81711 & 117.35041 & 1.33631 & 6.59081 & 130.49277 & 1.05431 & 4.08376 & 53.47844 \\
\hline 9 & 1.19674 & 7.26505 & 155.41439 & 1.23541 & 3.86898 & 54.05213 & 1.16675 & 5.44276 & 94.78876 \\
\hline 10 & 0.18224 & 0.57142 & 8.81699 & 0.24778 & 1.35476 & 27.27933 & 0.2377 & 1.38563 & 20.97565 \\
\hline 11 & 0.19618 & 0.58883 & 7.31965 & 0.35525 & 2.14785 & 44.21655 & 0.21328 & 1.10264 & 13.82238 \\
\hline 12 & 0.18962 & 0.51636 & 7.73027 & 0.31907 & 2.06764 & 42.862 & 0.1845 & 0.80463 & 12.45286 \\
\hline 13 & 0.1897 & 0.56395 & 7.25617 & 0.27749 & 1.59643 & 32.56279 & 0.22629 & 1.16674 & 20.57017 \\
\hline 14 & 0.18399 & 0.57897 & 8.47571 & 0.26125 & 1.24204 & 23.21421 & 0.26557 & 1.90186 & 36.30289 \\
\hline 15 & 0.5565 & 1.60685 & 17.22113 & 0.56843 & 1.8229 & 20.14432 & 1.59711 & 20.65957 & 454.01821 \\
\hline 16 & 0.55575 & 1.86439 & 22.55833 & 0.52773 & 1.71546 & 22.79832 & 1.62719 & 20.10234 & 439.60239 \\
\hline 17 & 0.20025 & 0.56121 & 7.781 & 0.3248 & 1.77606 & 35.50702 & 0.23746 & 1.46369 & 26.97981 \\
\hline 18 & 0.15905 & 0.49046 & 8.49094 & 0.30465 & 1.3537 & 24.92671 & 0.22303 & 1.46787 & 29.41638 \\
\hline
\end{tabular}


Tabela A.6 - Erros obtidos no teste, primeiro conjunto (com todos os dados), primavera.

\begin{tabular}{|c|c|c|c|c|c|c|c|c|c|}
\hline \multirow[t]{2}{*}{ Combinação } & \multicolumn{3}{|c|}{ Nível 1} & \multicolumn{3}{|c|}{ Nível 2} & \multicolumn{3}{|c|}{ Nível 3} \\
\hline & $\begin{array}{c}\text { Erro } \\
\text { relativo } \\
\text { médio }\end{array}$ & $\begin{array}{l}\text { Desvio } \\
\text { padrão }\end{array}$ & $\begin{array}{c}\text { Erro } \\
\text { relativo } \\
\text { máximo }\end{array}$ & $\begin{array}{c}\text { Erro } \\
\text { relativo } \\
\text { médio }\end{array}$ & $\begin{array}{l}\text { Desvio } \\
\text { padrão }\end{array}$ & $\begin{array}{c}\text { Erro } \\
\text { relativo } \\
\text { máximo }\end{array}$ & $\begin{array}{c}\text { Erro } \\
\text { relativo } \\
\text { médio }\end{array}$ & $\begin{array}{l}\text { Desvio } \\
\text { padrão }\end{array}$ & $\begin{array}{c}\text { Erro } \\
\text { relativo } \\
\text { máximo }\end{array}$ \\
\hline 1 & 0.98866 & 2.19801 & 21.42199 & 2.03792 & 10.2202 & 130.69062 & 1.35692 & 8.67645 & 136.51439 \\
\hline 2 & 1.07836 & 2.76437 & 29.27888 & 1.87078 & 9.79629 & 150.88262 & 1.63535 & 11.30451 & 178.52918 \\
\hline 3 & 1.33611 & 4.70911 & 55.58088 & 1.47361 & 4.9398 & 56.02583 & 1.23572 & 6.22903 & 99.66095 \\
\hline 4 & 0.97758 & 2.27985 & 26.40607 & 1.81349 & 11.24464 & 175.03436 & 1.40531 & 9.59148 & 154.14738 \\
\hline 5 & 1.44428 & 4.64534 & 63.58991 & 2.08543 & 10.02556 & 147.9885 & 1.28135 & 8.43984 & 138.39174 \\
\hline 6 & 0.63879 & 2.66685 & 37.19693 & 0.80057 & 4.77769 & 71.54497 & 0.5024 & 2.89034 & 47.05339 \\
\hline 7 & 0.78806 & 2.99539 & 34.36882 & 0.94766 & 7.30305 & 118.788 & 0.66564 & 4.13011 & 60.13988 \\
\hline 8 & 1.46293 & 5.30149 & 79.78715 & 1.98389 & 13.29695 & 211.89654 & 1.40703 & 8.08133 & 117.25691 \\
\hline 9 & 0.97589 & 2.07941 & 16.44599 & 3.01218 & 25.1018 & 404.81655 & 1.34743 & 7.68132 & 106.14548 \\
\hline 10 & 0.21374 & 0.55566 & 6.97409 & 0.28743 & 1.98255 & 31.74805 & 0.128 & 0.53317 & 6.65012 \\
\hline 11 & 0.25499 & 0.75002 & 6.99301 & 0.3688 & 2.58643 & 41.02644 & 0.12651 & 0.49572 & 6.84928 \\
\hline 12 & 0.28786 & 0.89337 & 9.99838 & 0.33674 & 2.54063 & 41.76778 & 0.20222 & 0.98485 & 12.96571 \\
\hline 13 & 0.24666 & 0.77462 & 9.80439 & 0.28008 & 1.98011 & 32.52702 & 0.12105 & 0.31502 & 3.03875 \\
\hline 14 & 0.20829 & 0.53282 & 4.80492 & 0.199 & 0.65357 & 6.89587 & 0.12534 & 0.3511 & 4.15612 \\
\hline 15 & 0.61272 & 1.81748 & 21.99455 & 0.83917 & 4.67549 & 67.72095 & 0.52296 & 2.49854 & 34.3997 \\
\hline 16 & 0.69984 & 2.97955 & 42.42996 & 0.77769 & 3.88834 & 51.50797 & 0.56483 & 2.86303 & 42.64503 \\
\hline 17 & 0.24388 & 0.65499 & 6.2596 & 0.37144 & 2.70106 & 43.04603 & 0.11408 & 0.33957 & 4.21165 \\
\hline 18 & 0.21609 & 0.59633 & 6.6792 & 0.31295 & 1.67206 & 25.21024 & 0.11995 & 0.42579 & 5.8639 \\
\hline
\end{tabular}


Tabela A.7 - Erros obtidos no treinamento, primeiro conjunto (com todos os dados), verão.

\begin{tabular}{|c|r|r|r|r|r|r|r|r|r|}
\hline \multirow{2}{*}{ Combinação } & \multicolumn{3}{|c|}{ Nível 1 } & \multicolumn{1}{c|}{ Nível 2 } & \multicolumn{1}{c|}{ Nível 3 } \\
\cline { 2 - 10 } & $\begin{array}{c}\text { Erro } \\
\text { relativo } \\
\text { médio }\end{array}$ & \multicolumn{1}{c|}{$\begin{array}{c}\text { Desvio } \\
\text { padrão }\end{array}$} & $\begin{array}{c}\text { Erro } \\
\text { relativo } \\
\text { máximo }\end{array}$ & $\begin{array}{c}\text { Erro } \\
\text { relativo } \\
\text { médio }\end{array}$ & $\begin{array}{c}\text { Desvio } \\
\text { padrão }\end{array}$ & $\begin{array}{c}\text { Erro } \\
\text { relativo } \\
\text { máximo }\end{array}$ & $\begin{array}{c}\text { Erro } \\
\text { relativo } \\
\text { médio }\end{array}$ & $\begin{array}{c}\text { Desvio } \\
\text { padrão }\end{array}$ & $\begin{array}{c}\text { Erro } \\
\text { relativo } \\
\text { máximo }\end{array}$ \\
\hline 1 & 1.4044 & 4.28582 & 43.56519 & 2.65887 & 20.25091 & 343.05893 & 1.29825 & 5.22199 & 72.98395 \\
\hline 2 & 1.43699 & 5.00504 & 72.24593 & 2.92973 & 23.0052 & 374.75205 & 1.419 & 8.68234 & 151.98163 \\
\hline 3 & 1.39464 & 5.01704 & 81.87144 & 3.41233 & 25.89492 & 534.7146 & 1.30436 & 9.6179 & 188.85334 \\
\hline 4 & 1.49904 & 6.04493 & 83.17623 & 2.56248 & 20.87157 & 341.29597 & 1.29005 & 6.76456 & 132.50276 \\
\hline 5 & 1.25053 & 4.2359 & 56.93263 & 1.59517 & 9.72269 & 152.22255 & 0.89033 & 4.2172 & 68.905 \\
\hline 6 & 0.45432 & 1.61987 & 29.4074 & 0.70998 & 4.14047 & 71.82141 & 1.53685 & 10.17195 & 183.82279 \\
\hline 7 & 0.44735 & 1.87756 & 38.60963 & 0.67842 & 3.92819 & 64.63963 & 1.30299 & 7.75435 & 136.18807 \\
\hline 8 & 1.19279 & 4.24956 & 66.58632 & 2.54085 & 20.03576 & 334.84983 & 1.38308 & 8.96013 & 190.14383 \\
\hline 9 & 1.21612 & 4.23152 & 68.01997 & 2.52584 & 19.47599 & 421.52731 & 1.3748 & 8.08221 & 158.17632 \\
\hline 10 & 0.21707 & 0.80394 & 14.43269 & 0.21608 & 0.71994 & 9.96665 & 0.22621 & 1.8518 & 35.51452 \\
\hline 11 & 0.22166 & 0.69644 & 9.82975 & 0.19622 & 0.67232 & 9.72172 & 0.24069 & 2.02403 & 42.92242 \\
\hline 12 & 0.2234 & 0.81575 & 14.1073 & 0.2037 & 0.71922 & 10.06263 & 0.23087 & 1.81712 & 34.45678 \\
\hline 13 & 0.20495 & 0.72483 & 13.0079 & 0.19329 & 0.69366 & 10.23645 & 0.27319 & 2.17575 & 45.3922 \\
\hline 14 & 0.21198 & 0.72587 & 11.82615 & 0.23367 & 0.93 & 14.16911 & 0.21287 & 1.02236 & 18.6657 \\
\hline 15 & 0.46553 & 1.54161 & 26.34669 & 0.68757 & 3.76405 & 66.22853 & 1.0173 & 6.39953 & 125.90128 \\
\hline 16 & 0.45325 & 1.66987 & 30.21016 & 0.80378 & 5.16033 & 98.65598 & 1.25494 & 8.49974 & 174.12592 \\
\hline 17 & 0.21766 & 0.77007 & 13.0853 & 0.23738 & 0.87879 & 10.57998 & 0.25319 & 2.03143 & 37.7214 \\
\hline 18 & 0.23387 & 0.77789 & 10.36025 & 0.26426 & 1.07749 & 14.37362 & 0.24468 & 2.01551 & 42.56451 \\
\hline
\end{tabular}


Tabela A.8 - Erros obtidos no teste, primeiro conjunto (com todos os dados), verão.

\begin{tabular}{|c|r|r|r|r|r|r|r|r|r|}
\hline \multirow{2}{*}{ Combinação } & \multicolumn{3}{|c|}{ Nível 1 } & \multicolumn{1}{c|}{ Nível 2 } & \multicolumn{2}{c|}{ Nível 3 } \\
\cline { 2 - 10 } & $\begin{array}{c}\text { Erro } \\
\text { relativo } \\
\text { médio }\end{array}$ & \multicolumn{1}{c|}{$\begin{array}{c}\text { Desvio } \\
\text { padrão }\end{array}$} & $\begin{array}{c}\text { Erro } \\
\text { relativo } \\
\text { máximo }\end{array}$ & $\begin{array}{c}\text { Erro } \\
\text { relativo } \\
\text { médio }\end{array}$ & $\begin{array}{c}\text { Desvio } \\
\text { padrão }\end{array}$ & $\begin{array}{c}\text { Erro } \\
\text { relativo } \\
\text { máximo }\end{array}$ & $\begin{array}{c}\text { Erro } \\
\text { relativo } \\
\text { médio }\end{array}$ & $\begin{array}{c}\text { Desvio } \\
\text { padrão }\end{array}$ & $\begin{array}{c}\text { Erro } \\
\text { relativo } \\
\text { máximo }\end{array}$ \\
\hline 1 & 1.97405 & 11.83056 & 190.89152 & 2.30644 & 12.6538 & 195.729 & 4.151 & 39.20126 & 629.70353 \\
\hline 2 & 1.7683 & 10.12893 & 164.2924 & 2.42372 & 12.1013 & 178.356 & 3.54959 & 34.53742 & 554.18679 \\
\hline 3 & 1.56933 & 5.09507 & 63.7675 & 3.4627 & 17.3221 & 256.81 & 2.37026 & 14.81419 & 215.65064 \\
\hline 4 & 1.93683 & 9.90548 & 152.38763 & 2.17791 & 11.0048 & 165.699 & 3.57686 & 35.59826 & 574.28033 \\
\hline 5 & 2.02815 & 12.32159 & 196.63807 & 2.1643 & 11.9831 & 184.948 & 2.14181 & 15.40409 & 242.61019 \\
\hline 6 & 0.48585 & 1.72564 & 23.12599 & 0.67006 & 3.2055 & 46.3933 & 3.43737 & 26.28193 & 383.6731 \\
\hline 7 & 0.47949 & 1.44812 & 16.47623 & 0.63249 & 3.02245 & 44.3116 & 2.51884 & 14.29039 & 153.83368 \\
\hline 8 & 1.76618 & 9.00556 & 142.51797 & 2.44062 & 15.0677 & 238.453 & 3.90509 & 38.67704 & 620.94546 \\
\hline 9 & 1.70538 & 6.36994 & 89.83228 & 2.99181 & 14.7099 & 223.204 & 4.12485 & 35.11482 & 543.76364 \\
\hline 10 & 0.32931 & 1.81185 & 28.48449 & 0.22042 & 0.73498 & 8.88978 & 0.42756 & 3.29012 & 46.60455 \\
\hline 11 & 0.27243 & 1.27644 & 19.86016 & 0.20386 & 0.66494 & 8.3658 & 0.51957 & 4.03268 & 57.22882 \\
\hline 12 & 0.35487 & 2.02691 & 32.11661 & 0.25127 & 1.17822 & 17.5398 & 0.45381 & 3.74866 & 56.15763 \\
\hline 13 & 0.31183 & 1.80589 & 28.94222 & 0.25849 & 1.25121 & 18.673 & 0.63159 & 4.93128 & 71.36562 \\
\hline 14 & 0.33621 & 1.86373 & 29.49459 & 0.26088 & 1.21191 & 17.5485 & 0.5184 & 3.32752 & 34.95907 \\
\hline 15 & 0.49692 & 1.4018 & 14.85803 & 0.62466 & 2.26572 & 27.6083 & 3.27264 & 26.9481 & 404.29426 \\
\hline 16 & 0.48765 & 1.71154 & 23.66084 & 0.86976 & 5.12217 & 78.7604 & 3.66162 & 30.19714 & 455.90234 \\
\hline 17 & 0.34901 & 2.00139 & 31.77539 & 0.26709 & 1.24708 & 18.8338 & 0.48861 & 3.73269 & 52.01565 \\
\hline 18 & 0.36141 & 1.96892 & 31.09437 & 0.24845 & 0.98936 & 13.1053 & 0.52326 & 3.76971 & 50.8476 \\
\hline
\end{tabular}


Tabela A.9 - Erros obtidos no treinamento, segundo conjunto (com dados filtrados), outono.

\begin{tabular}{|c|r|r|r|r|r|r|r|r|r|}
\hline \multirow{2}{*}{ Combinação } & \multicolumn{3}{|c|}{ Nível 1 } & \multicolumn{1}{c|}{ Nível 2 } & \multicolumn{2}{c|}{ Nível 3 } \\
\cline { 2 - 10 } & $\begin{array}{c}\text { Erro } \\
\text { relativo } \\
\text { médio }\end{array}$ & \multicolumn{1}{c|}{$\begin{array}{c}\text { Desvio } \\
\text { padrão }\end{array}$} & $\begin{array}{c}\text { Erro } \\
\text { relativo } \\
\text { máximo }\end{array}$ & $\begin{array}{c}\text { Erro } \\
\text { relativo } \\
\text { médio }\end{array}$ & $\begin{array}{l}\text { Desvio } \\
\text { padrão }\end{array}$ & $\begin{array}{c}\text { Erro } \\
\text { relativo } \\
\text { máximo }\end{array}$ & $\begin{array}{c}\text { Erro } \\
\text { relativo } \\
\text { médio }\end{array}$ & $\begin{array}{c}\text { Desvio } \\
\text { padrão }\end{array}$ & $\begin{array}{c}\text { Erro } \\
\text { relativo } \\
\text { máximo }\end{array}$ \\
\hline 1 & 0.67393 & 1.03171 & 11.66066 & 0.58765 & 0.73536 & 6.92145 & 0.5226 & 0.80578 & 9.60624 \\
\hline 2 & 0.66485 & 0.99658 & 10.36349 & 0.58354 & 0.72054 & 5.86108 & 0.53073 & 0.79439 & 10.38114 \\
\hline 3 & 0.58944 & 0.85003 & 9.87898 & 0.68466 & 1.10845 & 17.727 & 0.57766 & 0.73288 & 5.72941 \\
\hline 4 & 0.66285 & 0.80729 & 6.03745 & 0.56108 & 0.69471 & 5.4174 & 0.55498 & 0.84039 & 10.8275 \\
\hline 5 & 0.59644 & 0.82109 & 6.66295 & 0.6251 & 0.77677 & 5.36142 & 0.48194 & 0.68777 & 8.0001 \\
\hline 6 & 0.1448 & 0.18085 & 1.07965 & 0.2579 & 0.32128 & 2.58214 & 0.18912 & 0.25992 & 2.15235 \\
\hline 7 & 0.15851 & 0.21634 & 1.4497 & 0.2463 & 0.3273 & 2.76168 & 0.19187 & 0.26483 & 2.02742 \\
\hline 8 & 0.52842 & 0.70046 & 6.46551 & 0.48628 & 0.60369 & 4.6194 & 0.45272 & 0.61667 & 5.85059 \\
\hline 9 & 0.51517 & 0.63684 & 5.89368 & 0.47657 & 0.58532 & 4.84283 & 0.4483 & 0.60244 & 5.43274 \\
\hline 10 & 0.107 & 0.14001 & 0.98081 & 0.12045 & 0.15768 & 0.98457 & 0.11505 & 0.15209 & 1.26598 \\
\hline 11 & 0.09857 & 0.12265 & 0.9011 & 0.11702 & 0.15171 & 1.04481 & 0.11468 & 0.15118 & 1.12916 \\
\hline 12 & 0.10591 & 0.13644 & 1.04248 & 0.11286 & 0.13706 & 0.90393 & 0.11715 & 0.15104 & 0.99946 \\
\hline 13 & 0.10613 & 0.13692 & 1.01844 & 0.11477 & 0.1469 & 1.07632 & 0.115 & 0.14498 & 1.06055 \\
\hline 14 & 0.10198 & 0.12815 & 1.01317 & 0.11113 & 0.13053 & 0.77751 & 0.10618 & 0.1338 & 0.85188 \\
\hline 15 & 0.14221 & 0.17613 & 1.11476 & 0.26557 & 0.33249 & 2.05033 & 0.18527 & 0.25856 & 2.12919 \\
\hline 16 & 0.14294 & 0.17983 & 1.17324 & 0.22864 & 0.3153 & 2.83702 & 0.19739 & 0.26665 & 2.05093 \\
\hline 17 & 0.11025 & 0.1421 & 0.90867 & 0.11303 & 0.15049 & 1.1342 & 0.11565 & 0.14396 & 1.10144 \\
\hline 18 & 0.12107 & 0.15571 & 1.27135 & 0.11089 & 0.13829 & 1.12628 & 0.13753 & 0.18201 & 1.13213 \\
\hline
\end{tabular}


Tabela A.10 - Erros obtidos no teste, segundo conjunto (com dados filtrados), outono.

\begin{tabular}{|c|r|r|r|r|r|r|r|r|r|}
\hline \multirow{2}{*}{ Combinação } & \multicolumn{3}{|c|}{ Nível 1 } & \multicolumn{1}{c|}{ Nível 2 } & \multicolumn{2}{c|}{ Nível 3 } \\
\cline { 2 - 10 } & $\begin{array}{c}\text { Erro } \\
\text { relativo } \\
\text { médio }\end{array}$ & $\begin{array}{c}\text { Desvio } \\
\text { padrão }\end{array}$ & $\begin{array}{c}\text { Erro } \\
\text { relativo } \\
\text { máximo }\end{array}$ & $\begin{array}{c}\text { Erro } \\
\text { relativo } \\
\text { médio }\end{array}$ & $\begin{array}{c}\text { Desvio } \\
\text { padrão }\end{array}$ & $\begin{array}{c}\text { Erro } \\
\text { relativo } \\
\text { máximo }\end{array}$ & $\begin{array}{c}\text { Erro } \\
\text { relativo } \\
\text { médio }\end{array}$ & $\begin{array}{c}\text { Desvio } \\
\text { padrão }\end{array}$ & $\begin{array}{c}\text { Erro } \\
\text { relativo } \\
\text { máximo }\end{array}$ \\
\hline 1 & 0.58728 & 0.65239 & 4.43259 & 0.68502 & 0.76911 & 5.63663 & 0.54846 & 0.72709 & 7.15279 \\
\hline 2 & 0.56388 & 0.65408 & 4.80491 & 0.65354 & 0.78858 & 6.77449 & 0.64207 & 0.83783 & 6.34756 \\
\hline 3 & 0.62841 & 0.9819 & 9.38236 & 0.69133 & 0.90198 & 8.51492 & 0.66401 & 1.11011 & 12.21262 \\
\hline 4 & 0.64929 & 0.9219 & 9.24381 & 0.61852 & 0.64975 & 4.62548 & 0.61398 & 0.80671 & 7.01902 \\
\hline 5 & 0.65587 & 0.85946 & 6.75032 & 0.81542 & 0.97532 & 6.06345 & 0.55911 & 0.76883 & 6.60983 \\
\hline 6 & 0.15781 & 0.1935 & 1.26623 & 0.29116 & 0.32736 & 1.67099 & 0.20067 & 0.29357 & 2.50536 \\
\hline 7 & 0.16361 & 0.20264 & 1.14324 & 0.27476 & 0.31941 & 1.86118 & 0.21605 & 0.34471 & 3.68495 \\
\hline 8 & 0.68186 & 0.90243 & 6.60997 & 0.52714 & 0.63118 & 5.60778 & 0.51198 & 0.73713 & 6.50012 \\
\hline 9 & 0.56924 & 0.69905 & 6.07322 & 0.54383 & 0.66319 & 5.43542 & 0.51316 & 0.72822 & 6.65692 \\
\hline 10 & 0.10993 & 0.13346 & 0.98887 & 0.13387 & 0.14629 & 0.97762 & 0.11872 & 0.15636 & 1.26397 \\
\hline 11 & 0.10574 & 0.1381 & 1.11804 & 0.1383 & 0.15658 & 1.05189 & 0.11276 & 0.16258 & 0.99528 \\
\hline 12 & 0.10011 & 0.12138 & 0.67949 & 0.12405 & 0.13056 & 0.69585 & 0.11887 & 0.16176 & 1.07785 \\
\hline 13 & 0.10292 & 0.12647 & 0.72305 & 0.12236 & 0.13843 & 0.91089 & 0.12915 & 0.1869 & 1.45519 \\
\hline 14 & 0.08755 & 0.08948 & 0.44441 & 0.12379 & 0.13262 & 0.90517 & 0.11958 & 0.1598 & 0.98925 \\
\hline 15 & 0.16601 & 0.19785 & 1.11621 & 0.27913 & 0.31608 & 1.55308 & 0.20857 & 0.32454 & 2.78143 \\
\hline 16 & 0.1665 & 0.2055 & 1.33797 & 0.27283 & 0.34455 & 1.69145 & 0.21878 & 0.32448 & 2.80059 \\
\hline 17 & 0.10673 & 0.12305 & 0.69784 & 0.1263 & 0.14065 & 0.7482 & 0.12617 & 0.17355 & 1.21521 \\
\hline 18 & 0.11385 & 0.13589 & 0.97713 & 0.1277 & 0.14226 & 0.83773 & 0.14297 & 0.21433 & 2.32077 \\
\hline
\end{tabular}


Tabela A.11 - Erros obtidos no treinamento, segundo conjunto (com dados filtrados), inverno.

\begin{tabular}{|c|r|r|r|r|r|r|r|r|r|}
\hline \multirow{2}{*}{ Combinação } & \multicolumn{3}{|c|}{ Nível 1 } & \multicolumn{1}{c|}{ Nível 2 } & \multicolumn{2}{c|}{ Nível 3 } \\
\cline { 2 - 10 } & $\begin{array}{c}\text { Erro } \\
\text { relativo } \\
\text { médio }\end{array}$ & \multicolumn{1}{c|}{$\begin{array}{c}\text { Desvio } \\
\text { padrão }\end{array}$} & $\begin{array}{c}\text { Erro } \\
\text { relativo } \\
\text { máximo }\end{array}$ & $\begin{array}{c}\text { Erro } \\
\text { relativo } \\
\text { médio }\end{array}$ & $\begin{array}{c}\text { Desvio } \\
\text { padrão }\end{array}$ & $\begin{array}{c}\text { Erro } \\
\text { relativo } \\
\text { máximo }\end{array}$ & $\begin{array}{c}\text { Erro } \\
\text { relativo } \\
\text { médio }\end{array}$ & $\begin{array}{c}\text { Desvio } \\
\text { padrão }\end{array}$ & $\begin{array}{c}\text { Erro } \\
\text { relativo } \\
\text { máximo }\end{array}$ \\
\hline 1 & 0.42086 & 0.65194 & 11.02814 & 0.4089 & 0.50193 & 4.82969 & 0.36429 & 0.44585 & 3.00063 \\
\hline 2 & 0.41387 & 0.59252 & 7.49987 & 0.38217 & 0.42157 & 3.17485 & 0.35965 & 0.45241 & 3.79514 \\
\hline 3 & 0.38678 & 0.47 & 6.00809 & 0.83016 & 1.14886 & 14.43474 & 0.37173 & 0.50953 & 4.69826 \\
\hline 4 & 0.40676 & 0.4996 & 4.77997 & 0.44538 & 0.53627 & 4.65136 & 0.34631 & 0.43298 & 2.92825 \\
\hline 5 & 0.35322 & 0.52126 & 7.427 & 0.41996 & 0.56735 & 4.26785 & 0.31105 & 0.37449 & 2.46743 \\
\hline 6 & 0.15406 & 0.26956 & 2.39099 & 0.17831 & 0.25336 & 2.53882 & 0.14543 & 0.20798 & 1.73843 \\
\hline 7 & 0.14673 & 0.24884 & 2.15351 & 0.16925 & 0.25384 & 3.12855 & 0.1469 & 0.2141 & 1.69381 \\
\hline 8 & 0.35277 & 0.42586 & 4.92001 & 0.34999 & 0.41381 & 3.42829 & 0.30926 & 0.41964 & 3.62939 \\
\hline 9 & 0.34593 & 0.43067 & 4.56137 & 0.34252 & 0.41327 & 2.50346 & 0.30833 & 0.4011 & 3.5344 \\
\hline 10 & 0.07068 & 0.10463 & 0.8729 & 0.06426 & 0.08766 & 0.6605 & 0.06057 & 0.08643 & 0.7138 \\
\hline 11 & 0.07348 & 0.10553 & 0.7014 & 0.06323 & 0.08274 & 0.60802 & 0.06432 & 0.08914 & 0.62635 \\
\hline 12 & 0.06752 & 0.10876 & 1.13073 & 0.06634 & 0.08655 & 0.6338 & 0.05657 & 0.08072 & 0.67162 \\
\hline 13 & 0.07037 & 0.10867 & 1.13301 & 0.06356 & 0.08451 & 0.57268 & 0.05929 & 0.08724 & 0.76632 \\
\hline 14 & 0.06781 & 0.09987 & 0.72631 & 0.06333 & 0.08432 & 0.74612 & 0.0654 & 0.08817 & 0.73785 \\
\hline 15 & 0.15116 & 0.25558 & 2.31521 & 0.17228 & 0.23814 & 2.53112 & 0.13877 & 0.20693 & 1.67849 \\
\hline 16 & 0.14503 & 0.25145 & 2.40742 & 0.17798 & 0.24545 & 2.51863 & 0.14695 & 0.21882 & 1.70621 \\
\hline 17 & 0.0712 & 0.11048 & 1.04896 & 0.06617 & 0.08527 & 0.62495 & 0.06313 & 0.09073 & 0.78966 \\
\hline 18 & 0.0824 & 0.1228 & 0.86442 & 0.06185 & 0.07892 & 0.64177 & 0.06143 & 0.08961 & 0.83796 \\
\hline
\end{tabular}


Tabela A.12 - Erros obtidos no teste, segundo conjunto (com dados filtrados), inverno.

\begin{tabular}{|c|r|r|r|r|r|r|r|r|r|}
\hline Combinação & \multicolumn{3}{|c|}{ Nível 1 } & \multicolumn{1}{c|}{ Nível 2 } & \multicolumn{2}{c|}{ Nível 3 } \\
\cline { 2 - 10 } & $\begin{array}{c}\text { Erro } \\
\text { relativo } \\
\text { médio }\end{array}$ & $\begin{array}{c}\text { Desvio } \\
\text { padrão }\end{array}$ & $\begin{array}{c}\text { Erro } \\
\text { relativo } \\
\text { máximo }\end{array}$ & $\begin{array}{c}\text { Erro } \\
\text { relativo } \\
\text { médio }\end{array}$ & $\begin{array}{c}\text { Desvio } \\
\text { padrão }\end{array}$ & $\begin{array}{c}\text { Erro } \\
\text { relativo } \\
\text { máximo }\end{array}$ & $\begin{array}{c}\text { Erro } \\
\text { relativo } \\
\text { médio }\end{array}$ & $\begin{array}{c}\text { Desvio } \\
\text { padrão }\end{array}$ & $\begin{array}{c}\text { Erro } \\
\text { relativo } \\
\text { máximo }\end{array}$ \\
\hline 1 & 0.50497 & 0.59182 & 4.77874 & 0.518 & 0.60901 & 4.09149 & 0.43073 & 0.49577 & 3.35483 \\
\hline 2 & 0.46296 & 0.49447 & 2.86522 & 0.52458 & 0.64927 & 4.88103 & 0.39346 & 0.42778 & 2.8176 \\
\hline 3 & 0.50589 & 0.52264 & 3.38817 & 1.02943 & 1.24708 & 7.92567 & 0.43064 & 0.46216 & 2.87113 \\
\hline 4 & 0.46184 & 0.53822 & 3.42871 & 0.53123 & 0.6925 & 6.07328 & 0.4561 & 0.47942 & 3.14061 \\
\hline 5 & 0.54972 & 0.56681 & 4.86545 & 0.58157 & 0.67715 & 3.87637 & 0.3879 & 0.47641 & 3.95704 \\
\hline 6 & 0.14119 & 0.20746 & 1.91329 & 0.18843 & 0.25169 & 2.08059 & 0.12606 & 0.16479 & 1.29585 \\
\hline 7 & 0.1541 & 0.21084 & 1.71129 & 0.19323 & 0.29011 & 2.71661 & 0.13029 & 0.17125 & 1.50877 \\
\hline 8 & 0.43206 & 0.42748 & 2.68397 & 0.45301 & 0.53974 & 4.48017 & 0.35767 & 0.43098 & 2.79098 \\
\hline 9 & 0.41716 & 0.42546 & 2.47133 & 0.47344 & 0.65625 & 5.92367 & 0.38584 & 0.45442 & 2.87379 \\
\hline 10 & 0.0738 & 0.10897 & 0.65072 & 0.07098 & 0.09376 & 0.83599 & 0.05104 & 0.06523 & 0.41936 \\
\hline 11 & 0.07808 & 0.10603 & 0.76636 & 0.0714 & 0.09425 & 0.88386 & 0.05068 & 0.06553 & 0.44119 \\
\hline 12 & 0.07389 & 0.10972 & 0.6401 & 0.06475 & 0.08083 & 0.62021 & 0.04681 & 0.05868 & 0.36803 \\
\hline 13 & 0.07599 & 0.11091 & 0.81443 & 0.07161 & 0.09166 & 0.81555 & 0.04822 & 0.06215 & 0.42191 \\
\hline 14 & 0.07246 & 0.10778 & 0.74434 & 0.06807 & 0.08653 & 0.81145 & 0.05527 & 0.07467 & 0.53666 \\
\hline 15 & 0.15172 & 0.21908 & 1.94906 & 0.19615 & 0.26683 & 1.68611 & 0.12513 & 0.16698 & 1.39463 \\
\hline 16 & 0.14778 & 0.21198 & 2.01352 & 0.19527 & 0.26398 & 1.74363 & 0.12598 & 0.16666 & 1.52452 \\
\hline 17 & 0.07669 & 0.10929 & 0.87388 & 0.07102 & 0.09632 & 0.91765 & 0.05068 & 0.07046 & 0.50404 \\
\hline 18 & 0.09167 & 0.12985 & 0.92913 & 0.07078 & 0.08542 & 0.57842 & 0.05898 & 0.0784 & 0.52584 \\
\hline
\end{tabular}


Tabela A.13 - Erros obtidos no treinamento, segundo conjunto (com dados filtrados), primavera.

\begin{tabular}{|c|c|c|c|c|c|c|c|c|c|}
\hline \multirow[t]{2}{*}{ Combinação } & \multicolumn{3}{|c|}{ Nível 1} & \multicolumn{3}{|c|}{ Nível 2} & \multicolumn{3}{|c|}{ Nível 3} \\
\hline & $\begin{array}{c}\text { Erro } \\
\text { relativo } \\
\text { médio }\end{array}$ & $\begin{array}{l}\text { Desvio } \\
\text { padrão }\end{array}$ & $\begin{array}{c}\text { Erro } \\
\text { relativo } \\
\text { máximo }\end{array}$ & $\begin{array}{c}\text { Erro } \\
\text { relativo } \\
\text { médio }\end{array}$ & $\begin{array}{l}\text { Desvio } \\
\text { padrão }\end{array}$ & $\begin{array}{c}\text { Erro } \\
\text { relativo } \\
\text { máximo }\end{array}$ & $\begin{array}{c}\text { Erro } \\
\text { relativo } \\
\text { médio }\end{array}$ & $\begin{array}{l}\text { Desvio } \\
\text { padrão }\end{array}$ & $\begin{array}{c}\text { Erro } \\
\text { relativo } \\
\text { máximo }\end{array}$ \\
\hline 1 & 0.46998 & 0.55492 & 4.44836 & 0.42957 & 0.58284 & 5.2255 & 0.43385 & 0.52589 & 3.96671 \\
\hline 2 & 0.48734 & 0.58547 & 3.86663 & 0.46493 & 0.64166 & 6.67146 & 0.41089 & 0.53389 & 3.51189 \\
\hline 3 & 0.50888 & 0.55349 & 3.13863 & 0.6733 & 1.14991 & 13.63833 & 0.51257 & 0.84082 & 10.08352 \\
\hline 4 & 0.45489 & 0.58245 & 5.84967 & 0.44661 & 0.59596 & 5.94884 & 0.3911 & 0.51003 & 3.23073 \\
\hline 5 & 0.46226 & 0.5632 & 3.8016 & 0.43791 & 0.58578 & 6.34002 & 0.39192 & 0.52651 & 4.31782 \\
\hline 6 & 0.20053 & 0.36956 & 5.08925 & 0.18918 & 0.2702 & 2.4362 & 0.1923 & 0.3361 & 2.95969 \\
\hline 7 & 0.20809 & 0.3317 & 3.15858 & 0.18249 & 0.26611 & 2.40966 & 0.18806 & 0.33896 & 2.85019 \\
\hline 8 & 0.44438 & 0.5293 & 4.2757 & 0.47306 & 0.64177 & 6.622 & 0.38657 & 0.54929 & 4.45997 \\
\hline 9 & 0.41031 & 0.46053 & 3.42137 & 0.46437 & 0.63225 & 6.28255 & 0.38014 & 0.59124 & 4.68719 \\
\hline 10 & 0.07913 & 0.09573 & 0.74528 & 0.07672 & 0.10238 & 0.87408 & 0.06113 & 0.09674 & 0.70129 \\
\hline 11 & 0.0736 & 0.08643 & 0.57845 & 0.07513 & 0.0976 & 0.83244 & 0.05857 & 0.09383 & 0.65872 \\
\hline 12 & 0.08099 & 0.09795 & 0.83367 & 0.07047 & 0.09363 & 0.62492 & 0.05901 & 0.09246 & 0.81231 \\
\hline 13 & 0.08352 & 0.10281 & 0.72739 & 0.07511 & 0.09547 & 0.64417 & 0.05856 & 0.08912 & 0.64954 \\
\hline 14 & 0.08305 & 0.10491 & 0.90611 & 0.07221 & 0.09167 & 0.82486 & 0.05918 & 0.08914 & 0.67531 \\
\hline 15 & 0.19668 & 0.41461 & 7.00235 & 0.1915 & 0.26861 & 2.17394 & 0.1951 & 0.34024 & 2.94022 \\
\hline 16 & 0.20203 & 0.38544 & 5.48264 & 0.18707 & 0.25578 & 1.86382 & 0.1927 & 0.33372 & 2.67277 \\
\hline 17 & 0.07812 & 0.09222 & 0.83155 & 0.07118 & 0.09461 & 0.796 & 0.05926 & 0.09015 & 0.66525 \\
\hline 18 & 0.07581 & 0.09205 & 0.93519 & 0.07309 & 0.09194 & 0.81256 & 0.05975 & 0.09963 & 0.75354 \\
\hline
\end{tabular}


Tabela A.14 - Erros obtidos no teste, segundo conjunto (com dados filtrados), primavera.

\begin{tabular}{|c|c|c|c|c|c|c|c|c|c|}
\hline \multirow[t]{2}{*}{ Combinação } & \multicolumn{3}{|c|}{ Nível 1} & \multicolumn{3}{|c|}{ Nível 2} & \multicolumn{3}{|c|}{ Nível 3} \\
\hline & $\begin{array}{c}\text { Erro } \\
\text { relativo } \\
\text { médio }\end{array}$ & $\begin{array}{l}\text { Desvio } \\
\text { padrão }\end{array}$ & $\begin{array}{c}\text { Erro } \\
\text { relativo } \\
\text { máximo }\end{array}$ & $\begin{array}{c}\text { Erro } \\
\text { relativo } \\
\text { médio }\end{array}$ & $\begin{array}{l}\text { Desvio } \\
\text { padrão }\end{array}$ & $\begin{array}{c}\text { Erro } \\
\text { relativo } \\
\text { máximo }\end{array}$ & $\begin{array}{c}\text { Erro } \\
\text { relativo } \\
\text { médio }\end{array}$ & $\begin{array}{l}\text { Desvio } \\
\text { padrão }\end{array}$ & $\begin{array}{c}\text { Erro } \\
\text { relativo } \\
\text { máximo }\end{array}$ \\
\hline 1 & 0.57932 & 0.95626 & 9.82731 & 0.54842 & 0.88569 & 7.81354 & 0.54697 & 0.71348 & 5.1819 \\
\hline 2 & 0.63793 & 1.14973 & 11.69014 & 0.57989 & 0.87534 & 6.66761 & 0.5175 & 0.70451 & 5.40327 \\
\hline 3 & 0.64155 & 0.86189 & 6.06197 & 0.72823 & 0.99599 & 6.51461 & 1.57141 & 7.57301 & 87.36604 \\
\hline 4 & 0.6052 & 1.2238 & 12.27728 & 0.54371 & 0.83566 & 5.92006 & 0.51187 & 0.73505 & 5.33047 \\
\hline 5 & 0.58838 & 1.00904 & 10.43852 & 0.61941 & 0.80815 & 4.78036 & 0.53698 & 0.71743 & 5.07596 \\
\hline 6 & 0.19928 & 0.3793 & 4.32428 & 0.22211 & 0.33159 & 1.8297 & 0.21978 & 0.31205 & 2.10276 \\
\hline 7 & 0.23998 & 0.41033 & 3.56605 & 0.23149 & 0.33936 & 2.20279 & 0.21865 & 0.31868 & 2.20061 \\
\hline 8 & 0.53391 & 0.89194 & 7.24981 & 0.61423 & 1.21142 & 14.03008 & 0.48309 & 0.69109 & 5.57218 \\
\hline 9 & 0.55087 & 0.88124 & 7.63223 & 0.52774 & 0.82605 & 6.36652 & 0.55513 & 0.73137 & 6.09866 \\
\hline 10 & 0.08054 & 0.09457 & 0.65234 & 0.07934 & 0.11067 & 0.86013 & 0.06001 & 0.08245 & 0.4993 \\
\hline 11 & 0.07891 & 0.09636 & 0.63815 & 0.07453 & 0.09735 & 0.61717 & 0.05591 & 0.07721 & 0.47684 \\
\hline 12 & 0.08534 & 0.10039 & 0.68876 & 0.07442 & 0.10678 & 0.82937 & 0.06678 & 0.09744 & 0.65919 \\
\hline 13 & 0.08216 & 0.09255 & 0.63437 & 0.07772 & 0.10851 & 0.7711 & 0.05861 & 0.0816 & 0.44147 \\
\hline 14 & 0.07479 & 0.08335 & 0.56878 & 0.0767 & 0.09848 & 0.56382 & 0.05271 & 0.06334 & 0.35628 \\
\hline 15 & 0.19304 & 0.30926 & 2.67773 & 0.2266 & 0.33519 & 2.12907 & 0.21423 & 0.29557 & 2.02418 \\
\hline 16 & 0.20236 & 0.39191 & 4.33227 & 0.2202 & 0.31721 & 1.92813 & 0.22555 & 0.35659 & 2.60537 \\
\hline 17 & 0.08127 & 0.0984 & 0.71397 & 0.07823 & 0.10415 & 0.83967 & 0.05761 & 0.07905 & 0.43559 \\
\hline 18 & 0.08836 & 0.11334 & 0.84061 & 0.07687 & 0.10335 & 0.76272 & 0.05751 & 0.08563 & 0.65429 \\
\hline
\end{tabular}


Tabela A.15 - Erros obtidos no treinamento, segundo conjunto (com dados filtrados), verão.

\begin{tabular}{|c|c|c|c|c|c|c|c|c|c|}
\hline \multirow[t]{2}{*}{ Combinação } & \multicolumn{3}{|c|}{ Nível 1} & \multicolumn{3}{|c|}{ Nível 2} & \multicolumn{3}{|c|}{ Nível 3} \\
\hline & $\begin{array}{c}\text { Erro } \\
\text { relativo } \\
\text { médio } \\
\end{array}$ & $\begin{array}{l}\text { Desvio } \\
\text { padrão }\end{array}$ & $\begin{array}{c}\text { Erro } \\
\text { relativo } \\
\text { máximo } \\
\end{array}$ & $\begin{array}{c}\text { Erro } \\
\text { relativo } \\
\text { médio } \\
\end{array}$ & $\begin{array}{l}\text { Desvio } \\
\text { padrão }\end{array}$ & $\begin{array}{c}\text { Erro } \\
\text { relativo } \\
\text { máximo } \\
\end{array}$ & $\begin{array}{c}\text { Erro } \\
\text { relativo } \\
\text { médio } \\
\end{array}$ & $\begin{array}{l}\text { Desvio } \\
\text { padrão }\end{array}$ & $\begin{array}{c}\text { Erro } \\
\text { relativo } \\
\text { máximo }\end{array}$ \\
\hline 1 & 0.60592 & 0.73503 & 6.7588 & 0.57279 & 0.90446 & 9.41444 & 0.34429 & 0.46051 & 4.09897 \\
\hline 2 & 0.56869 & 0.70283 & 5.15711 & 0.58337 & 0.89192 & 8.12937 & 0.3249 & 0.45588 & 4.50087 \\
\hline 3 & 0.53849 & 0.63517 & 4.51117 & 0.63099 & 0.90758 & 8.57472 & 0.39714 & 0.54915 & 5.64835 \\
\hline 4 & 0.56347 & 0.68795 & 6.12288 & 0.56525 & 0.86709 & 8.22729 & 0.31075 & 0.37919 & 3.1268 \\
\hline 5 & 0.54183 & 0.68455 & 5.48738 & 0.46418 & 0.70173 & 6.0227 & 0.30931 & 0.40467 & 3.25983 \\
\hline 6 & 0.17323 & 0.21026 & 1.68587 & 0.20602 & 0.38458 & 5.77787 & 0.20558 & 0.3063 & 2.50096 \\
\hline 7 & 0.17171 & 0.20451 & 1.56748 & 0.18838 & 0.30036 & 3.43387 & 0.17886 & 0.27578 & 2.11429 \\
\hline 8 & 0.52916 & 0.62821 & 4.638 & 0.48824 & 0.67442 & 6.12058 & 0.35025 & 0.46264 & 2.90416 \\
\hline 9 & 0.5112 & 0.62973 & 4.42002 & 0.46311 & 0.69277 & 6.82613 & 0.33757 & 0.41926 & 3.51738 \\
\hline 10 & 0.08212 & 0.08904 & 0.67487 & 0.07375 & 0.09051 & 0.7118 & 0.04598 & 0.06349 & 0.41018 \\
\hline 11 & 0.08351 & 0.09351 & 0.78935 & 0.07251 & 0.08845 & 0.60925 & 0.04771 & 0.06543 & 0.57127 \\
\hline 13 & 0.08368 & 0.09155 & 0.74751 & 0.07387 & 0.09207 & 0.80597 & 0.04615 & 0.06567 & 0.53997 \\
\hline 14 & 0.08377 & 0.09168 & 0.78841 & 0.07306 & 0.08816 & 0.55008 & 0.04666 & 0.06482 & 0.60416 \\
\hline 15 & 0.18118 & 0.22897 & 1.732 & 0.20749 & 0.36726 & 5.08582 & 0.18905 & 0.26808 & 0.26808 \\
\hline 16 & 0.17263 & 0.20768 & 1.58407 & 0.19168 & 0.38498 & 6.24644 & 0.20779 & 0.31332 & 2.57561 \\
\hline 17 & 0.08618 & 0.10141 & 0.92183 & 0.07408 & 0.08989 & 0.63534 & 0.0459 & 0.06624 & 0.55749 \\
\hline 18 & 0.09091 & 0.10809 & 0.93139 & 0.07332 & 0.09465 & 0.74011 & 0.04573 & 0.0645 & 0.58687 \\
\hline
\end{tabular}


Tabela A.16 - Erros obtidos no teste, segundo conjunto (com dados filtrados), verão.

\begin{tabular}{|c|r|r|r|r|r|r|r|r|r|}
\hline \multirow{2}{*}{ Combinação } & \multicolumn{3}{|c|}{ Nível 1 } & \multicolumn{1}{c|}{ Nível 2 } & \multicolumn{2}{c|}{ Nível 3 } \\
\cline { 2 - 10 } & $\begin{array}{c}\text { Erro } \\
\text { relativo } \\
\text { médio }\end{array}$ & \multicolumn{1}{c|}{$\begin{array}{c}\text { Desvio } \\
\text { padrão }\end{array}$} & $\begin{array}{c}\text { Erro } \\
\text { relativo } \\
\text { máximo }\end{array}$ & $\begin{array}{c}\text { Erro } \\
\text { relativo } \\
\text { médio }\end{array}$ & $\begin{array}{l}\text { Desvio } \\
\text { padrão }\end{array}$ & $\begin{array}{c}\text { Erro } \\
\text { relativo } \\
\text { máximo }\end{array}$ & $\begin{array}{c}\text { Erro } \\
\text { relativo } \\
\text { médio }\end{array}$ & $\begin{array}{c}\text { Desvio } \\
\text { padrão }\end{array}$ & $\begin{array}{c}\text { Erro } \\
\text { relativo } \\
\text { máximo }\end{array}$ \\
\hline 1 & 0.70319 & 0.81325 & 4.91393 & 0.64043 & 0.9453 & 8.47756 & 0.48654 & 0.88743 & 10.52993 \\
\hline 2 & 0.68885 & 0.8946 & 7.39695 & 0.70688 & 1.09837 & 8.30569 & 0.52545 & 0.92162 & 11.31342 \\
\hline 3 & 0.63508 & 0.78671 & 4.81277 & 0.84701 & 1.14132 & 8.01888 & 0.56592 & 1.01033 & 11.67221 \\
\hline 4 & 0.68925 & 0.85591 & 5.65706 & 0.68433 & 0.99109 & 6.80618 & 0.51676 & 1.15959 & 15.74094 \\
\hline 5 & 0.65097 & 0.76618 & 4.68913 & 0.63493 & 0.72204 & 4.37915 & 0.59862 & 1.52433 & 21.00308 \\
\hline 6 & 0.21338 & 0.37932 & 4.86275 & 0.20774 & 0.33588 & 3.55092 & 0.23947 & 0.39864 & 4.19683 \\
\hline 7 & 0.22458 & 0.37987 & 4.69901 & 0.20512 & 0.32325 & 3.5857 & 0.21917 & 0.39608 & 4.92818 \\
\hline 8 & 0.62776 & 0.71174 & 4.56582 & 0.64107 & 0.92466 & 7.57783 & 0.42077 & 0.96642 & 13.20356 \\
\hline 9 & 0.6165 & 0.77369 & 5.42952 & 0.62475 & 0.79312 & 5.88219 & 0.50726 & 1.15504 & 15.69928 \\
\hline 10 & 0.09794 & 0.10878 & 0.70167 & 0.07758 & 0.08846 & 0.56788 & 0.05046 & 0.06266 & 0.48537 \\
\hline 11 & 0.0959 & 0.10633 & 0.71818 & 0.07523 & 0.09121 & 0.68029 & 0.04902 & 0.05632 & 0.32358 \\
\hline 12 & 0.11226 & 0.12523 & 0.66824 & 0.07681 & 0.09283 & 0.63095 & 0.04978 & 0.06282 & 0.41583 \\
\hline 13 & 0.10701 & 0.12207 & 0.76596 & 0.08037 & 0.0978 & 0.6159 & 0.04951 & 0.06171 & 0.49099 \\
\hline 14 & 0.10209 & 0.11132 & 0.64265 & 0.07363 & 0.088 & 0.60029 & 0.04979 & 0.0595 & 0.46584 \\
\hline 15 & 0.21465 & 0.38467 & 4.81624 & 0.21539 & 0.34951 & 3.58756 & 0.22102 & 0.33069 & 3.04924 \\
\hline 16 & 0.22035 & 0.36916 & 4.50065 & 0.1885 & 0.2979 & 3.38421 & 0.24462 & 0.40417 & 3.84541 \\
\hline 17 & 0.11084 & 0.1181 & 0.81275 & 0.08322 & 0.09968 & 0.57706 & 0.05067 & 0.06542 & 0.52188 \\
\hline 18 & 0.11359 & 0.12406 & 0.74679 & 0.08353 & 0.10428 & 0.63094 & 0.05048 & 0.06011 & 0.37097 \\
\hline
\end{tabular}


Tabela A.17 - Lista parcial dos resultados do treinamento para a combinação 6 (7 variáveis de entrada), primeiro conjunto (com todos os dados).

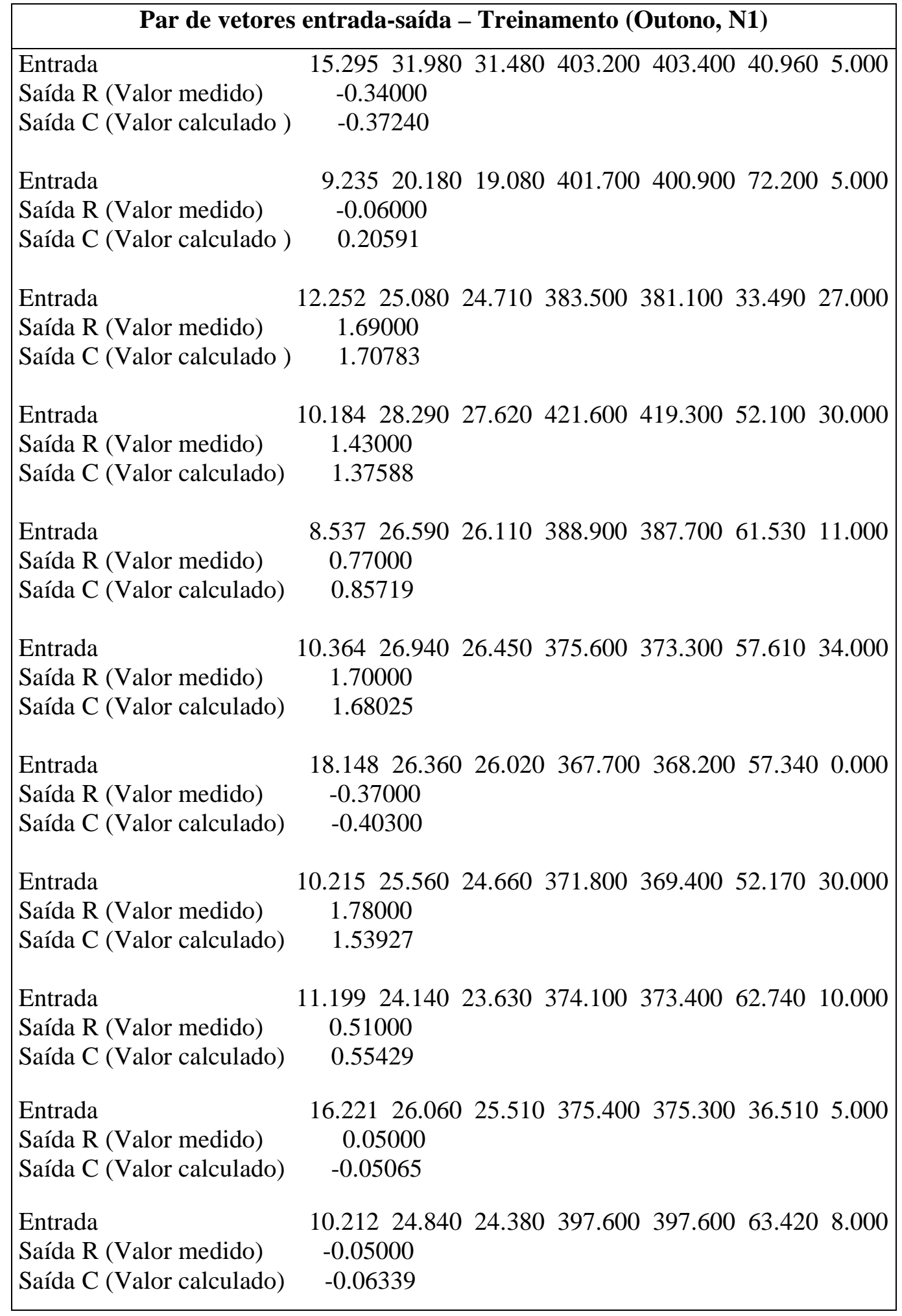


Tabela A.18 - Lista parcial dos resultados do teste para a combinação 6 (7 variáveis de entrada), primeiro conjunto (com todos os dados).

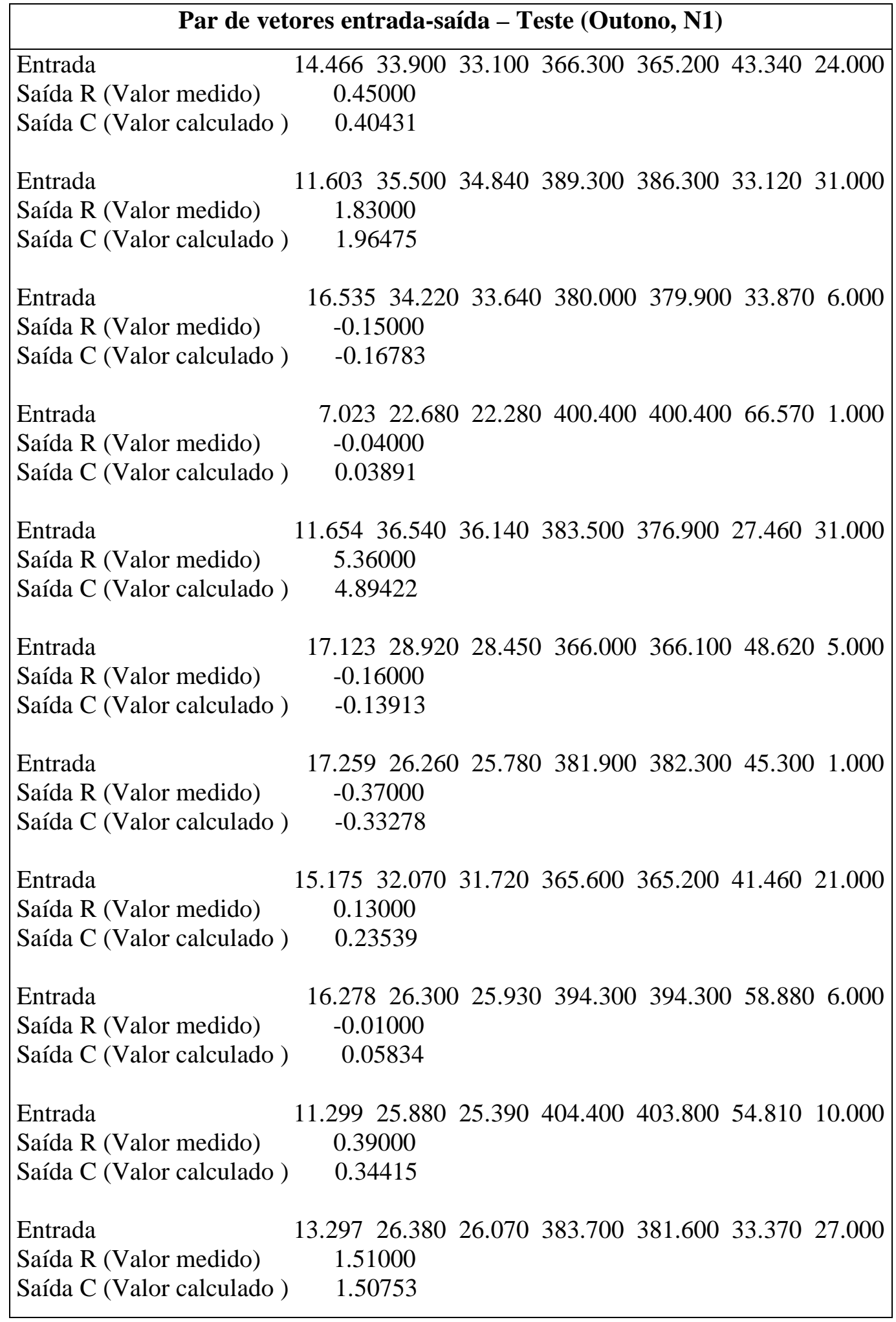


Tabela A.19 - Lista parcial dos resultados do treinamento para a combinação 11 (8 variáveis de entrada), primeiro conjunto (com todos os dados).

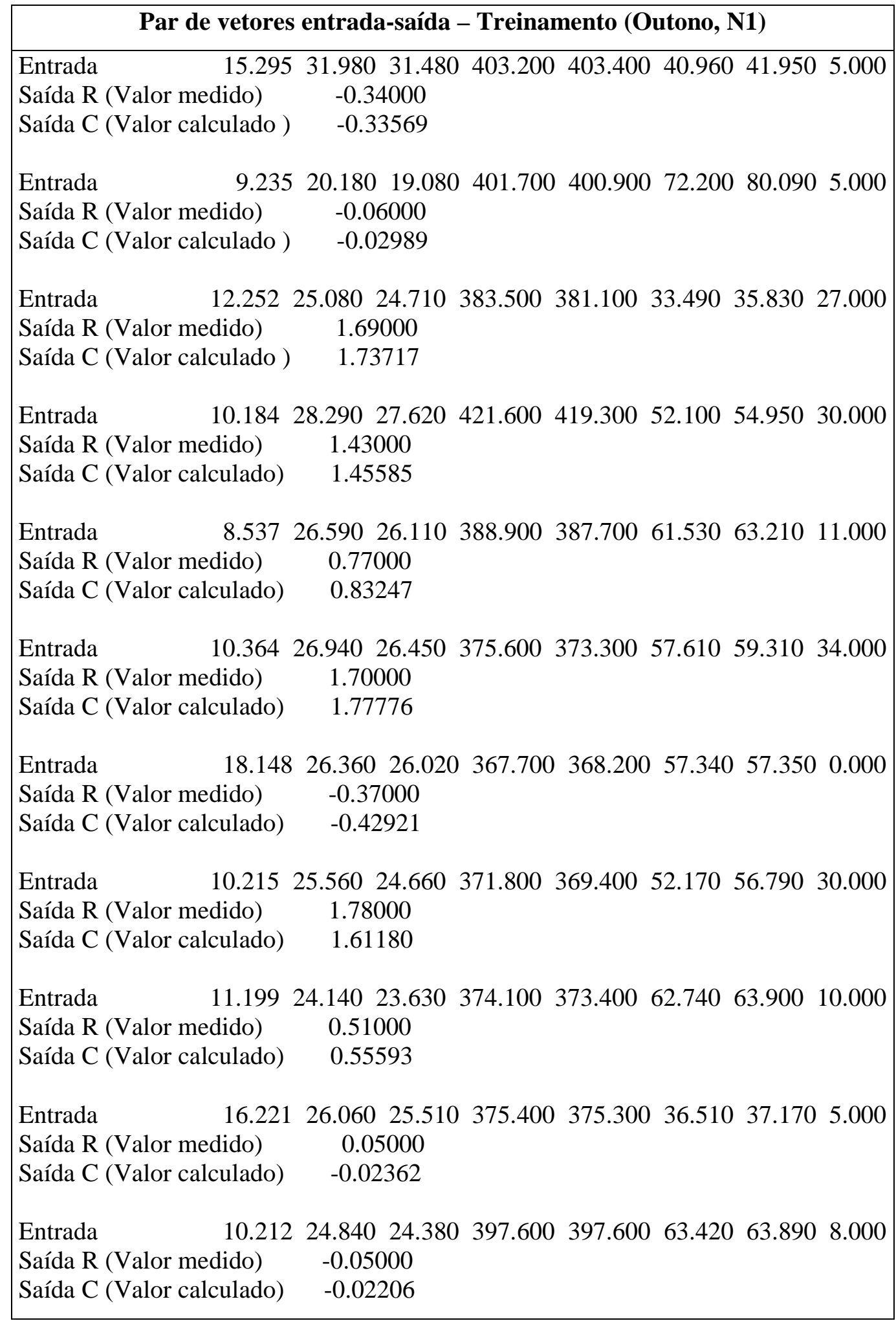


Tabela A.20 - Lista parcial dos resultados do teste para a combinação 11 (8 variáveis de entrada), primeiro conjunto (com todos os dados).

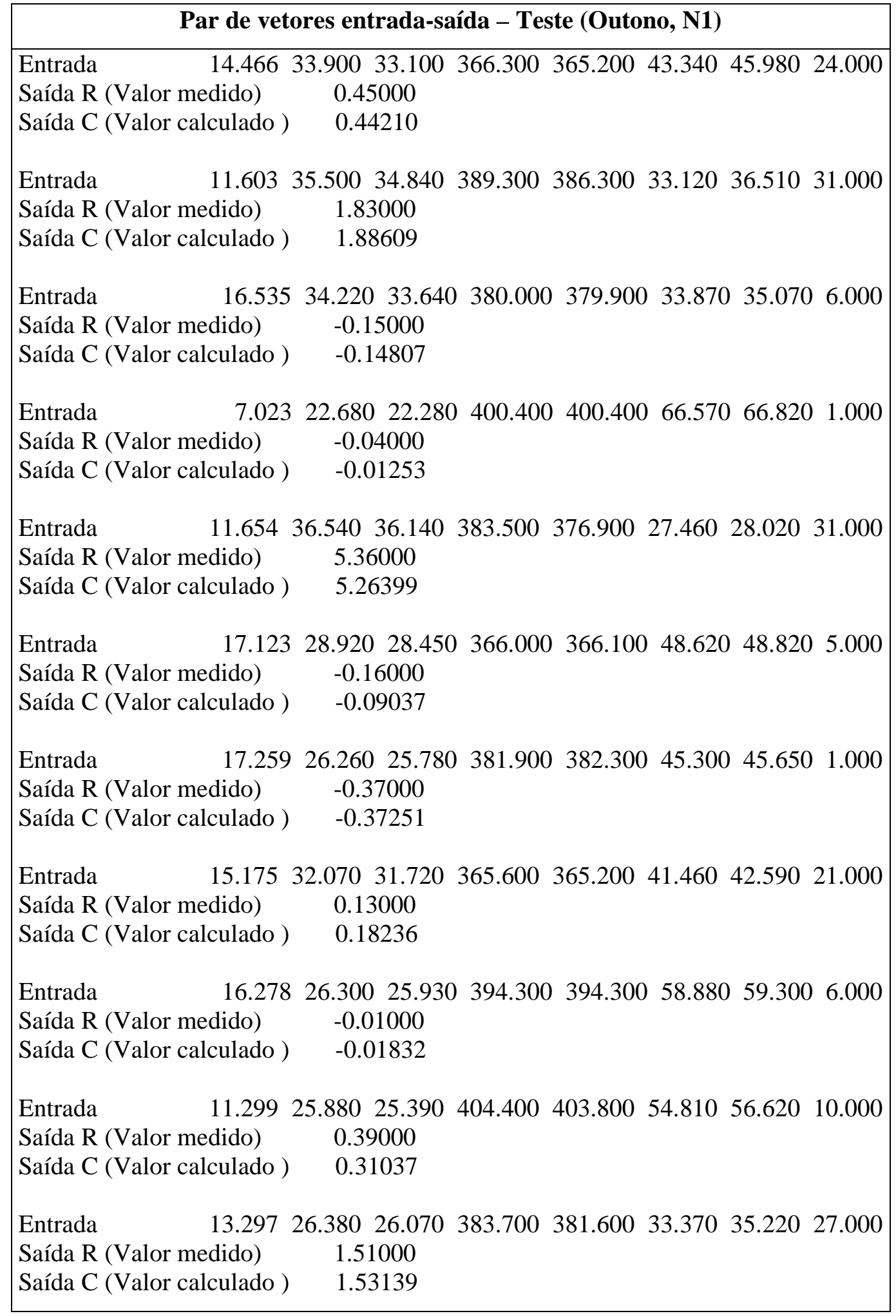


Tabela A. 21 - Lista parcial dos resultados do treinamento para a combinação 1 (6 variáveis de entrada), segundo conjunto (com dados filtrados).

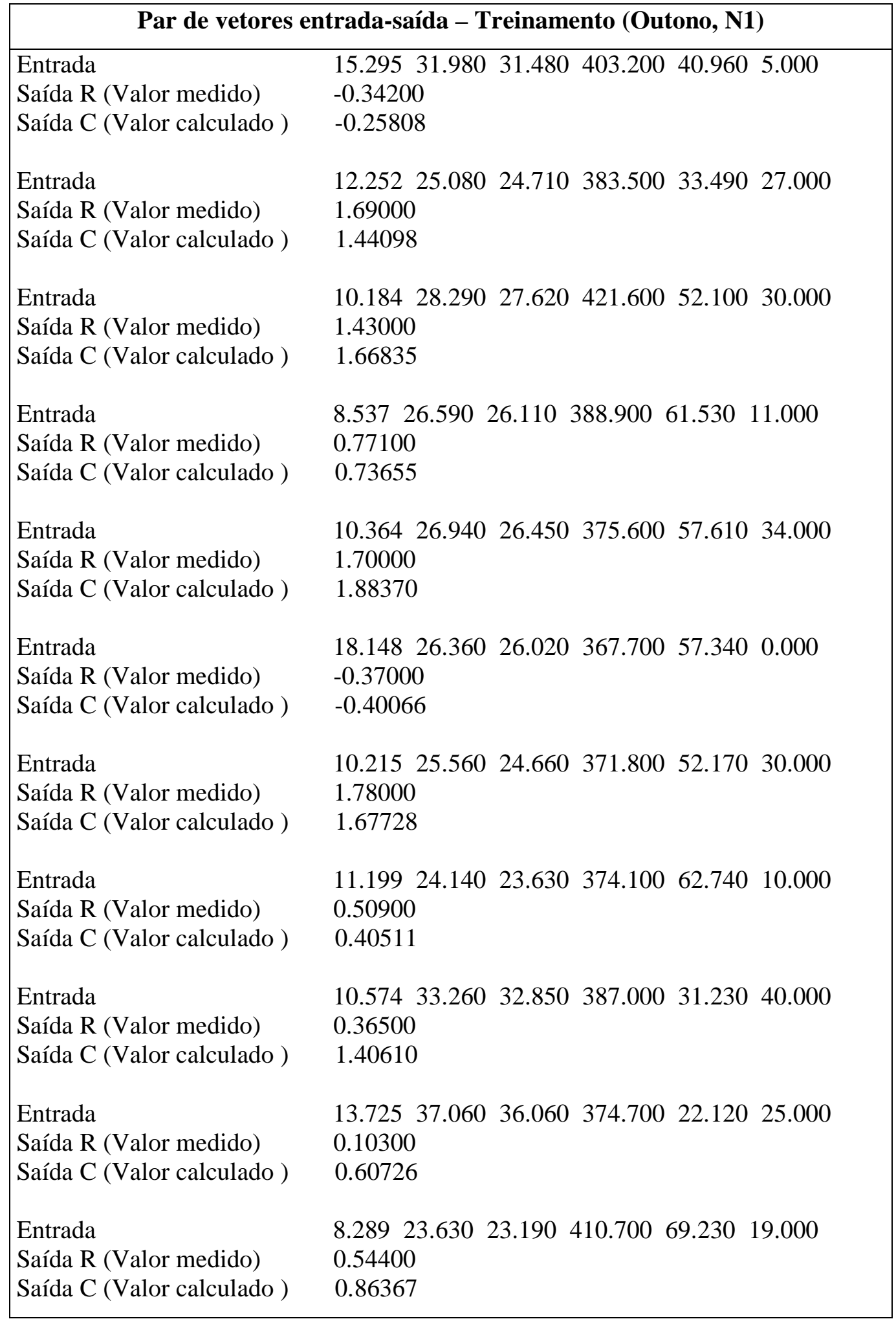


Tabela A.22 - Lista parcial dos resultados do teste para a combinação 1 (6 variáveis de entrada), segundo conjunto (com dados filtrados).

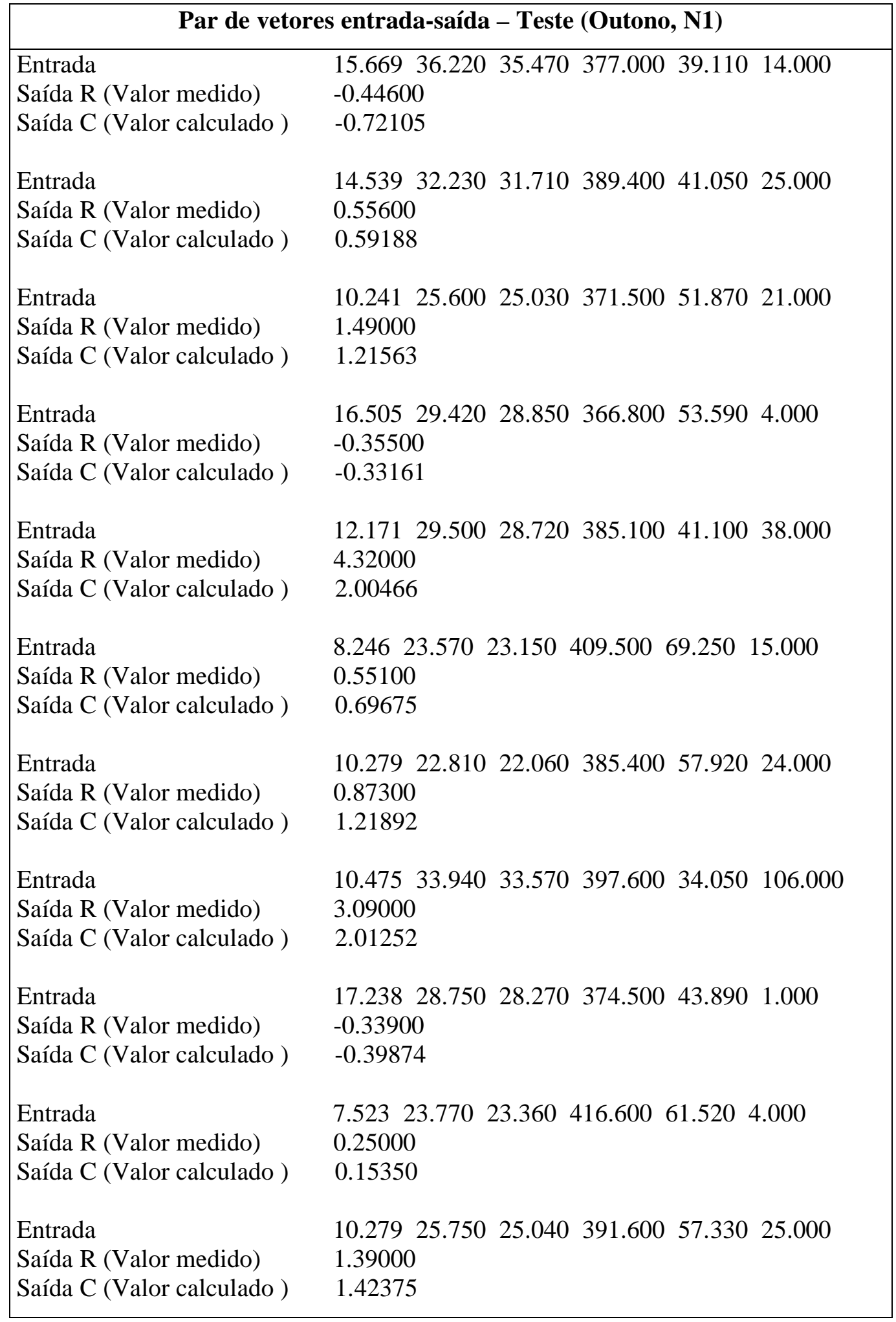


Tabela A.23 - Lista parcial dos resultados do treinamento para a combinação 6 (7 variáveis de entrada), segundo conjunto (com dados filtrados).

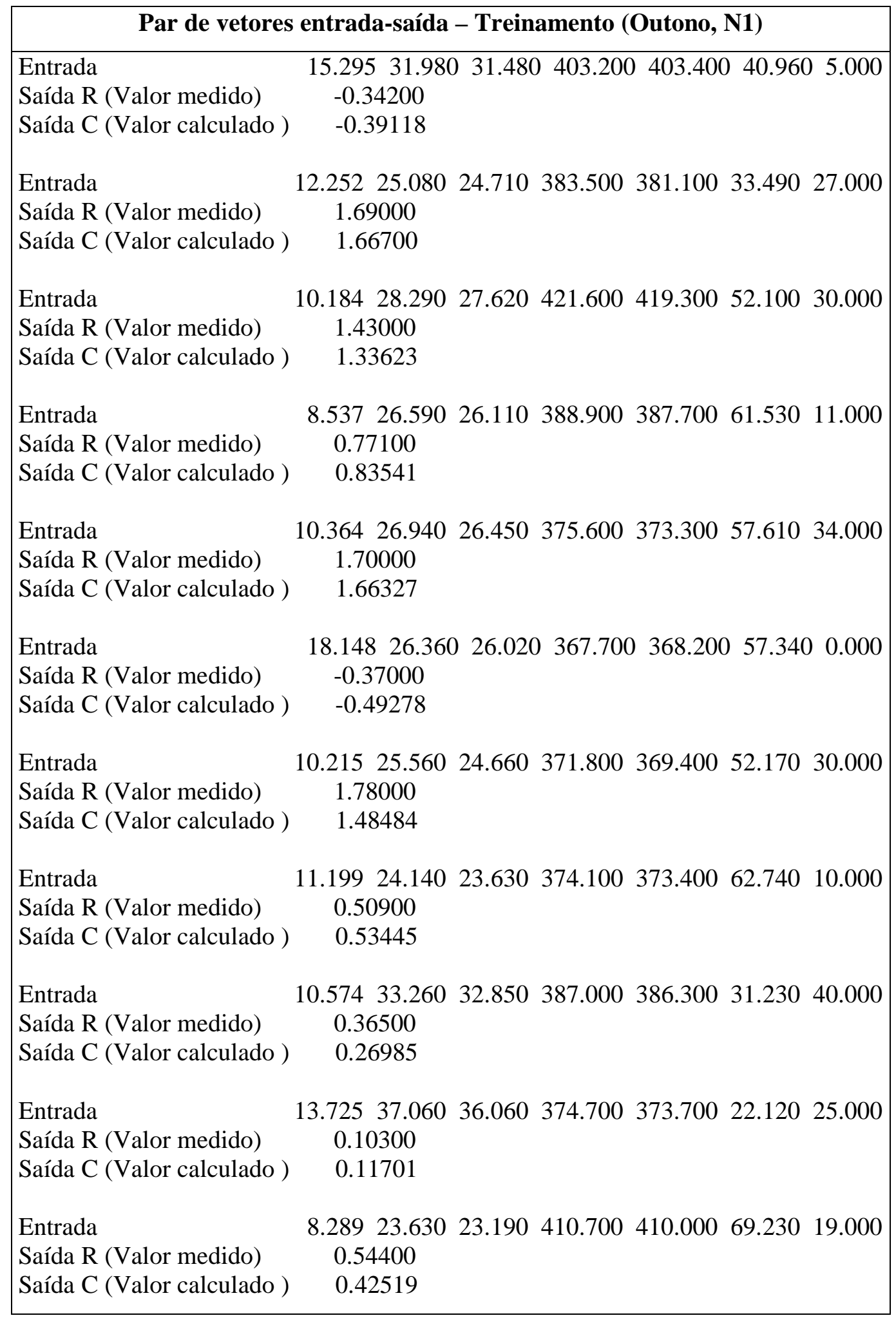


Tabela A.24 - Lista parcial dos resultados do teste para a combinação 6 (7 variáveis de entrada), segundo conjunto (com dados filtrados).

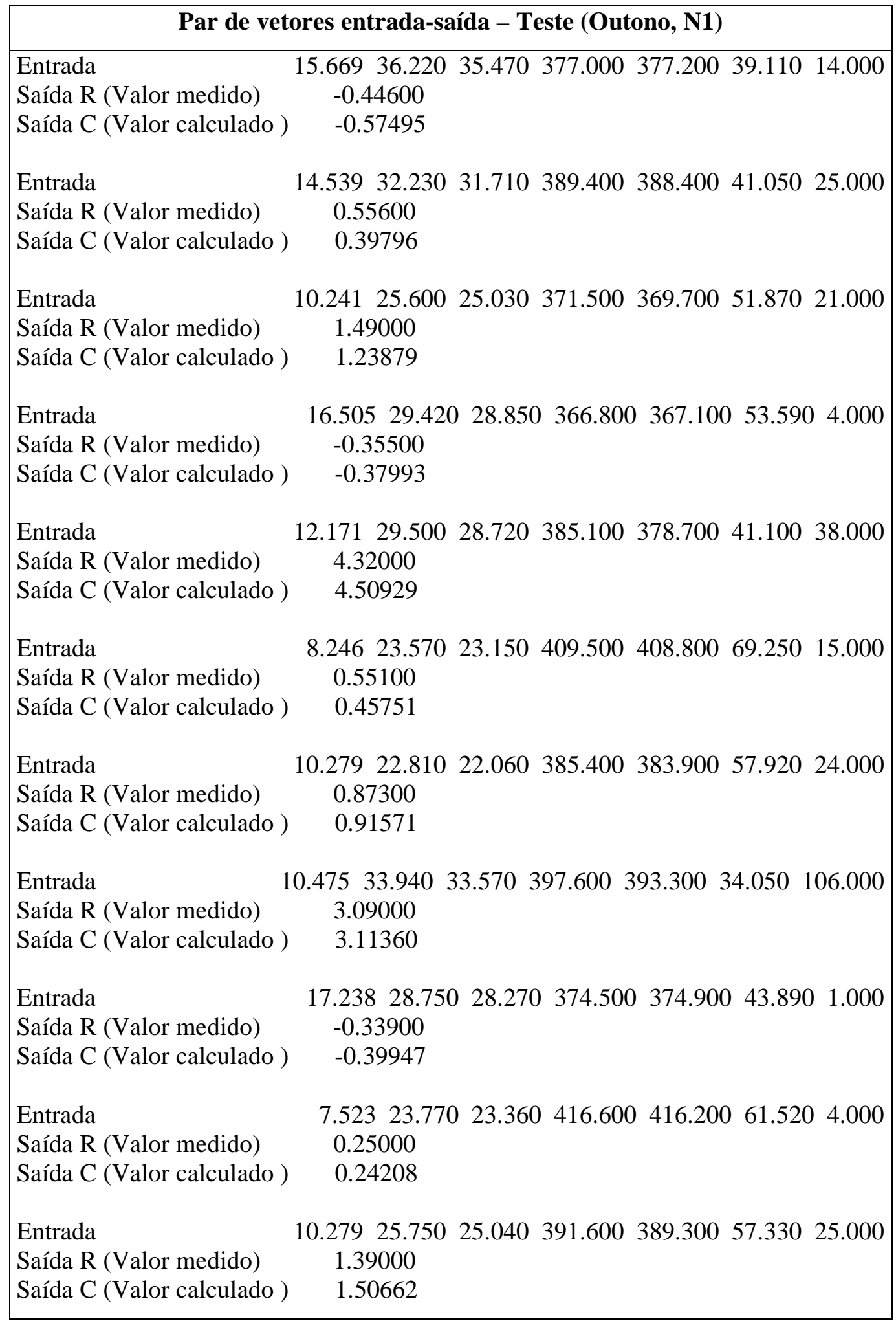


Tabela A.25 - Lista parcial dos resultados do treinamento para a combinação 11 (8 variáveis de entrada), segundo conjunto (com dados filtrados).

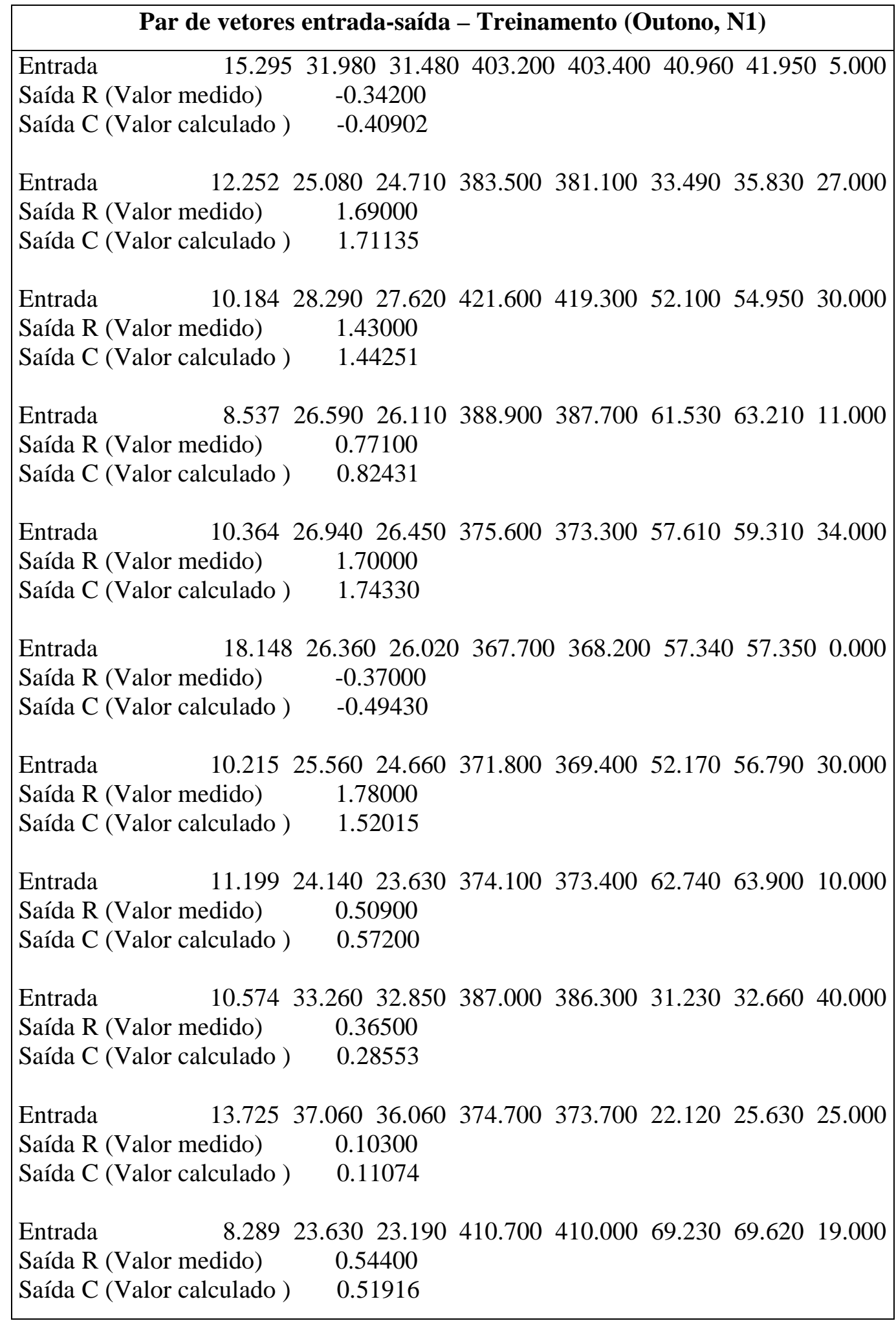


Tabela A.26 - Lista parcial dos resultados do teste para a combinação 11 (8 variáveis de entrada), segundo conjunto (com dados filtrados).

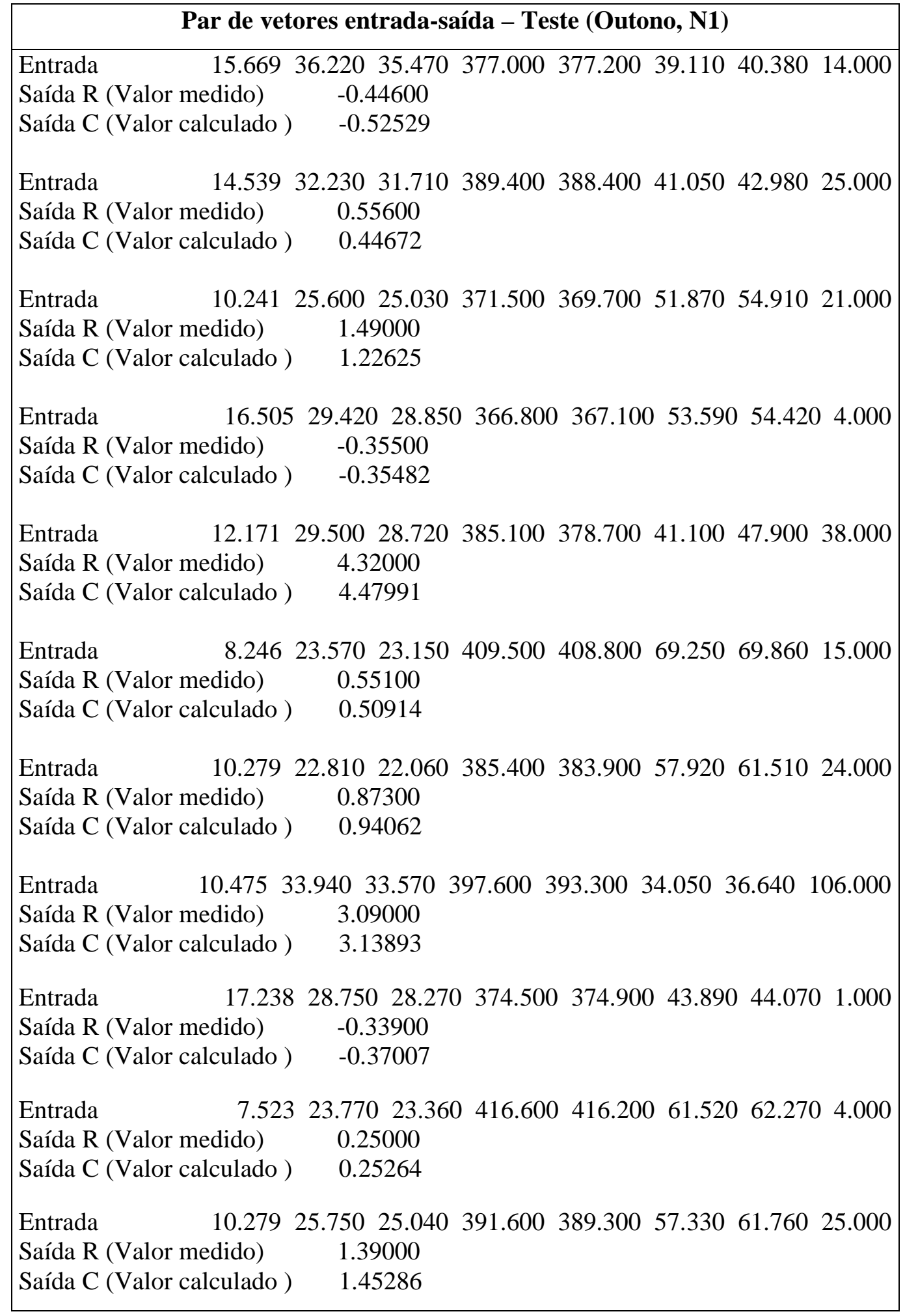




\section{APÊNDICE B}

\section{RESULTADOS DOS TREINAMENTOS DA SEGUNDA \\ FASE DA MODELAGEM}


Tabela B.1 - Erros obtidos no treinamento, primeiro conjunto (com todos os dados).

\begin{tabular}{|c|r|r|r|r|r|r|r|r|r|}
\hline \multirow{2}{*}{ Combinação } & \multicolumn{3}{|c|}{ Nível 1 } & \multicolumn{2}{|c|}{ Nível 2 } & \multicolumn{2}{c|}{ Nível 3 } \\
\cline { 2 - 10 } & $\begin{array}{c}\text { Erro } \\
\text { relativo } \\
\text { médio }\end{array}$ & $\begin{array}{c}\text { Desvio } \\
\text { padrão }\end{array}$ & $\begin{array}{c}\text { Erro } \\
\text { relativo } \\
\text { máximo }\end{array}$ & $\begin{array}{c}\text { Erro } \\
\text { relativo } \\
\text { médio }\end{array}$ & $\begin{array}{l}\text { Desvio } \\
\text { padrão }\end{array}$ & $\begin{array}{c}\text { Erro } \\
\text { relativo } \\
\text { máximo }\end{array}$ & $\begin{array}{c}\text { Erro } \\
\text { relativo } \\
\text { médio }\end{array}$ & $\begin{array}{c}\text { Desvio } \\
\text { padrão }\end{array}$ & $\begin{array}{c}\text { Erro } \\
\text { relativo } \\
\text { máximo }\end{array}$ \\
\hline 1 & 1.49383 & 7.5379 & 190.887 & 1.53808 & 9.25413 & 260.107 & 1.28523 & 7.38414 & 165.574 \\
\hline 2 & 1.39546 & 6.79354 & 190.722 & 1.4597 & 7.89822 & 262.753 & 1.27908 & 7.7357 & 223.143 \\
\hline 3 & 1.50286 & 6.61202 & 164.881 & 1.39519 & 5.62771 & 126.266 & 1.27572 & 7.98395 & 261.221 \\
\hline 4 & 1.38306 & 6.02503 & 179.414 & 1.26469 & 5.61204 & 188.473 & 1.43073 & 9.31622 & 303.474 \\
\hline 5 & 0.44913 & 2.02487 & 61.829 & 0.64242 & 3.43532 & 85.2513 & 0.89888 & 9.94929 & 362.177 \\
\hline 6 & 0.22946 & 1.42475 & 44.1824 & 0.26478 & 1.58102 & 46.8261 & 0.30174 & 2.27207 & 50.5015 \\
\hline 7 & 0.22944 & 1.45269 & 40.8394 & 0.26998 & 1.67497 & 51.784 & 0.2974 & 2.19047 & 50.7412 \\
\hline 8 & 0.23813 & 1.27672 & 30.3949 & 0.26309 & 1.48592 & 36.3281 & 0.31059 & 2.44986 & 65.2607 \\
\hline 9 & 0.21759 & 1.28243 & 47.4453 & 0.24879 & 1.18765 & 35.1707 & 0.30168 & 2.48819 & 73.4098 \\
\hline 10 & 0.2474 & 1.56193 & 44.0038 & 0.26425 & 1.55054 & 40.6838 & 0.30621 & 2.44252 & 62.74 \\
\hline
\end{tabular}


Tabela B.2 - Erros obtidos no teste, primeiro conjunto (com todos os dados).

\begin{tabular}{|c|r|r|r|r|r|r|r|r|r|}
\hline \multirow{2}{*}{ Combinação } & \multicolumn{3}{|c|}{ Nível 1 } & \multicolumn{1}{c|}{ Nível 2 } & \multicolumn{3}{c|}{ Nível 3 } \\
\cline { 2 - 11 } & $\begin{array}{c}\text { Erro } \\
\text { relativo } \\
\text { médio }\end{array}$ & $\begin{array}{c}\text { Desvio } \\
\text { padrão }\end{array}$ & $\begin{array}{c}\text { Erro } \\
\text { relativo } \\
\text { máximo }\end{array}$ & $\begin{array}{c}\text { Erro } \\
\text { relativo } \\
\text { médio }\end{array}$ & $\begin{array}{c}\text { Desvio } \\
\text { padrão }\end{array}$ & $\begin{array}{c}\text { Erro } \\
\text { relativo } \\
\text { máximo }\end{array}$ & $\begin{array}{c}\text { Erro } \\
\text { relativo } \\
\text { médio }\end{array}$ & $\begin{array}{c}\text { Desvio } \\
\text { padrão }\end{array}$ & $\begin{array}{c}\text { Erro } \\
\text { relativo } \\
\text { máximo }\end{array}$ \\
\hline 1 & 1.26056 & 4.03479 & 69.2833 & 1.27147 & 4.76669 & 79.0285 & 1.14503 & 4.87954 & 107.439 \\
\hline 2 & 1.21235 & 4.21995 & 87.7893 & 1.42131 & 6.12127 & 123.304 & 1.19393 & 7.25264 & 174.414 \\
\hline 3 & 1.28426 & 4.25948 & 68.4496 & 1.50349 & 5.61657 & 86.8557 & 1.34027 & 9.60211 & 248.138 \\
\hline 4 & 1.38487 & 4.81427 & 100.902 & 1.47346 & 6.05711 & 94.691 & 1.19115 & 5.96005 & 123.136 \\
\hline 5 & 0.48484 & 2.22103 & 42.2104 & 0.54838 & 2.1833 & 39.6394 & 0.57818 & 2.8565 & 48.5681 \\
\hline 6 & 0.19188 & 0.54601 & 7.78067 & 0.25156 & 1.31989 & 30.0509 & 0.21507 & 0.97094 & 14.5619 \\
\hline 7 & 0.18478 & 0.51764 & 7.41322 & 0.25301 & 1.38617 & 32.7176 & 0.26031 & 1.40568 & 19.3981 \\
\hline 8 & 0.21328 & 0.59435 & 8.22636 & 0.23572 & 1.1731 & 25.3344 & 0.27476 & 1.6064 & 25.6785 \\
\hline 9 & 0.20469 & 0.59592 & 9.05871 & 0.25881 & 1.58486 & 41.381 & 0.20482 & 0.83385 & 11.8092 \\
\hline 10 & 0.19814 & 0.525 & 7.73386 & 0.25154 & 1.29232 & 29.8984 & 0.26651 & 1.52261 & 24.18 \\
\hline
\end{tabular}


Tabela B.3 - Erros obtidos no treinamento, segundo conjunto (com dados filtrados).

\begin{tabular}{|c|r|r|r|r|r|r|r|r|r|}
\hline \multirow{2}{*}{ Combinação } & \multicolumn{3}{|c|}{ Nível 1 } & \multicolumn{1}{c|}{ Nível 2 } & \multicolumn{3}{c|}{ Nível 3 } \\
\cline { 2 - 11 } & $\begin{array}{c}\text { Erro } \\
\text { relativo } \\
\text { médio }\end{array}$ & $\begin{array}{c}\text { Desvio } \\
\text { padrão }\end{array}$ & $\begin{array}{c}\text { Erro } \\
\text { relativo } \\
\text { máximo }\end{array}$ & $\begin{array}{c}\text { Erro } \\
\text { relativo } \\
\text { médio }\end{array}$ & $\begin{array}{c}\text { Desvio } \\
\text { padrão }\end{array}$ & $\begin{array}{c}\text { Erro } \\
\text { relativo } \\
\text { máximo }\end{array}$ & $\begin{array}{c}\text { Erro } \\
\text { relativo } \\
\text { médio }\end{array}$ & $\begin{array}{c}\text { Desvio } \\
\text { padrão }\end{array}$ & $\begin{array}{c}\text { Erro } \\
\text { relativo } \\
\text { máximo }\end{array}$ \\
\hline 1 & 0.55765 & 0.69987 & 9.23866 & 0.52705 & 0.69057 & 12.0398 & 0.43642 & 0.54162 & 5.56769 \\
\hline 2 & 0.5562 & 0.71126 & 10.6689 & 0.54486 & 0.66498 & 8.71981 & 0.41549 & 0.53412 & 6.63872 \\
\hline 3 & 0.55501 & 0.67098 & 9.806 & 0.52021 & 0.65965 & 10.1363 & 0.4158 & 0.5398 & 6.83656 \\
\hline 4 & 0.52427 & 0.62335 & 9.55635 & 0.51745 & 0.62633 & 8.75004 & 0.45396 & 0.60376 & 5.8574 \\
\hline 5 & 0.18244 & 0.29827 & 5.44373 & 0.21888 & 0.34293 & 6.18828 & 0.2177 & 0.31792 & 3.28992 \\
\hline 6 & 0.08043 & 0.09968 & 0.95318 & 0.08931 & 0.11446 & 0.98741 & 0.06757 & 0.0938 & 0.86661 \\
\hline 7 & 0.08105 & 0.0985 & 0.82095 & 0.08725 & 0.11077 & 0.92038 & 0.06699 & 0.09371 & 0.92328 \\
\hline 8 & 0.08019 & 0.09773 & 0.74783 & 0.08281 & 0.10518 & 0.9241 & 0.06351 & 0.08643 & 0.73586 \\
\hline 9 & 0.07961 & 0.09961 & 0.83515 & 0.08542 & 0.10916 & 0.95619 & 0.06503 & 0.09225 & 1.14205 \\
\hline 10 & 0.07799 & 0.09787 & 1.00948 & 0.07942 & 0.10015 & 0.98661 & 0.06512 & 0.08921 & 0.80087 \\
\hline
\end{tabular}


Tabela B.4 - Erros obtidos no teste, segundo conjunto (com dados filtrados).

\begin{tabular}{|c|r|r|r|r|r|r|r|r|r|}
\hline \multirow{2}{*}{ Combinação } & \multicolumn{3}{|c|}{ Nível 1 } & \multicolumn{1}{c|}{ Nível 2 } & \multicolumn{3}{c|}{ Nível 3 } \\
\cline { 2 - 11 } & $\begin{array}{c}\text { Erro } \\
\text { relativo } \\
\text { médio }\end{array}$ & \multicolumn{1}{c|}{$\begin{array}{c}\text { Desvio } \\
\text { padrão }\end{array}$} & $\begin{array}{c}\text { Erro } \\
\text { relativo } \\
\text { máximo }\end{array}$ & $\begin{array}{c}\text { Erro } \\
\text { relativo } \\
\text { médio }\end{array}$ & $\begin{array}{c}\text { Desvio } \\
\text { padrão }\end{array}$ & $\begin{array}{c}\text { Erro } \\
\text { relativo } \\
\text { máximo }\end{array}$ & $\begin{array}{c}\text { Erro } \\
\text { relativo } \\
\text { médio }\end{array}$ & $\begin{array}{c}\text { Desvio } \\
\text { padrão }\end{array}$ & $\begin{array}{c}\text { Erro } \\
\text { relativo } \\
\text { máximo }\end{array}$ \\
\hline 1 & 0.64168 & 0.88764 & 10.3486 & 0.581 & 0.96223 & 12.6704 & 0.51627 & 0.76236 & 11.9832 \\
\hline 2 & 0.6281 & 0.93018 & 12.7162 & 0.6099 & 0.9368 & 14.3962 & 0.5006 & 0.75108 & 13.7826 \\
\hline 3 & 0.64251 & 0.89649 & 11.9402 & 0.62306 & 0.94365 & 13.9919 & 0.48419 & 0.65233 & 9.22931 \\
\hline 4 & 0.6726 & 1.024 & 14.9124 & 0.5761 & 0.73722 & 7.17048 & 0.55422 & 0.86682 & 14.5969 \\
\hline 5 & 0.19829 & 0.31578 & 4.13951 & 0.21111 & 0.31312 & 3.55933 & 0.23782 & 0.35762 & 3.70086 \\
\hline 6 & 0.08801 & 0.1042 & 1.1831 & 0.08744 & 0.12022 & 1.14353 & 0.07469 & 0.10538 & 0.81256 \\
\hline 7 & 0.0893 & 0.10637 & 1.16556 & 0.08771 & 0.11699 & 1.02116 & 0.07506 & 0.10488 & 0.81415 \\
\hline 8 & 0.08765 & 0.10671 & 1.14793 & 0.08449 & 0.11793 & 1.26466 & 0.0719 & 0.09819 & 0.74233 \\
\hline 9 & 0.08755 & 0.10812 & 1.18896 & 0.0875 & 0.11754 & 1.05889 & 0.07442 & 0.10639 & 0.94856 \\
\hline 10 & 0.08746 & 0.10383 & 1.01395 & 0.08025 & 0.10613 & 0.80107 & 0.07463 & 0.10475 & 0.73698 \\
\hline
\end{tabular}


Tabela B.5 - Lista parcial dos resultados do treinamento para a combinação 1 (6 variáveis de entrada), primeiro conjunto (com todos os dados).

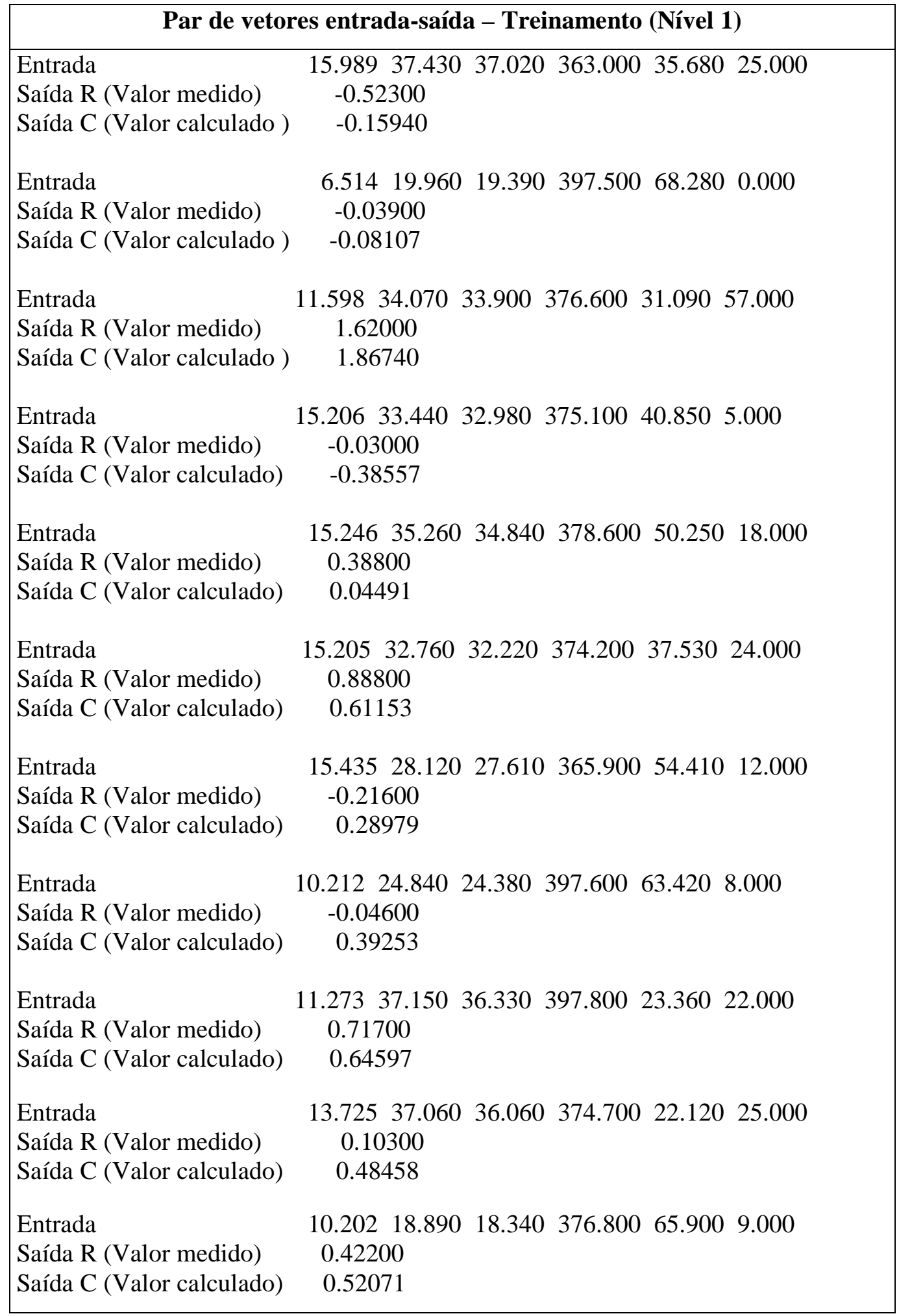


Tabela B.6 - Lista parcial dos resultados do teste para a combinação 1 (6 variáveis de entrada), primeiro conjunto (com todos os dados).

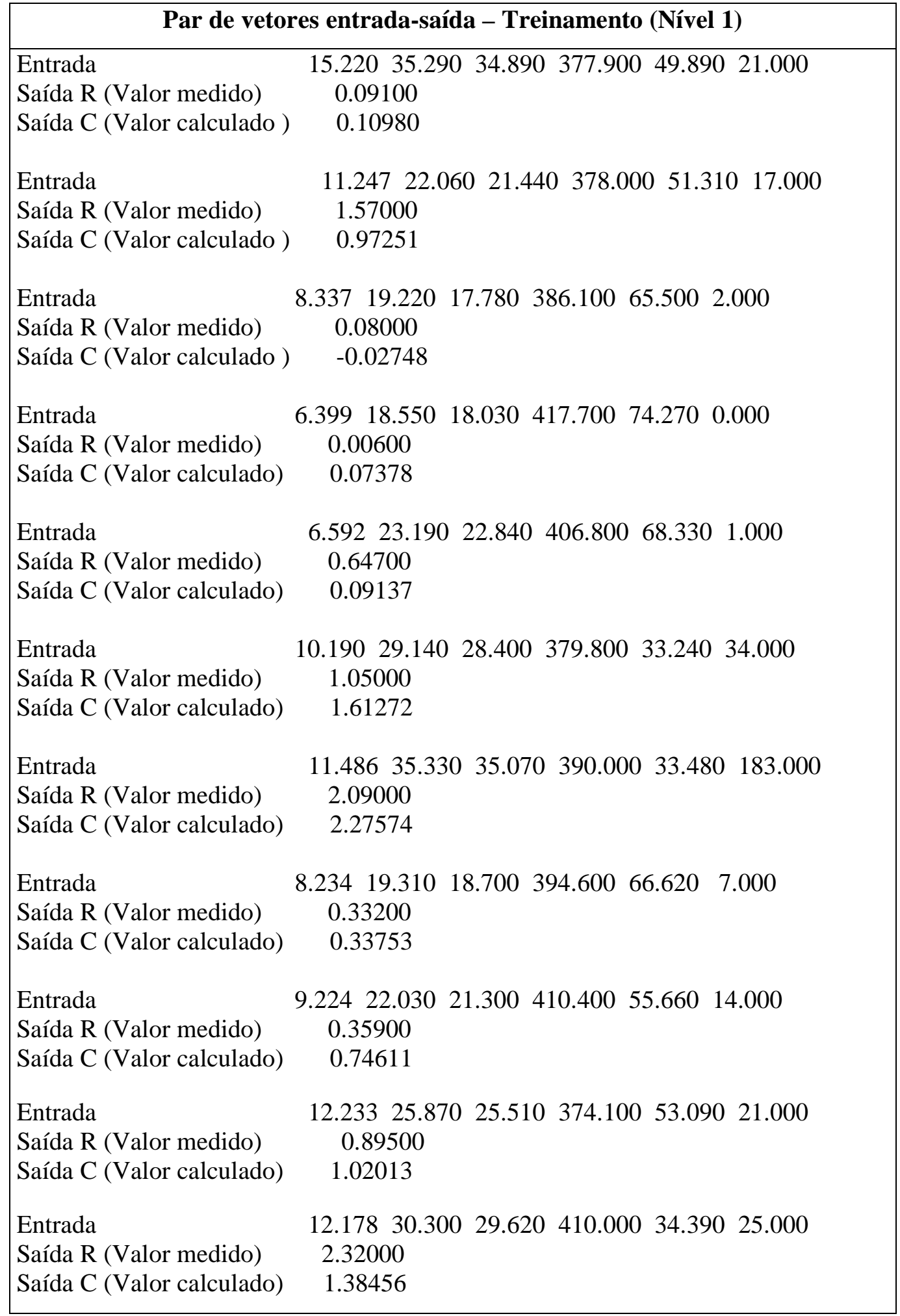


Tabela B.7 - Lista parcial dos resultados do treinamento para a combinação 5 (7 variáveis de entrada), primeiro conjunto (com todos os dados).

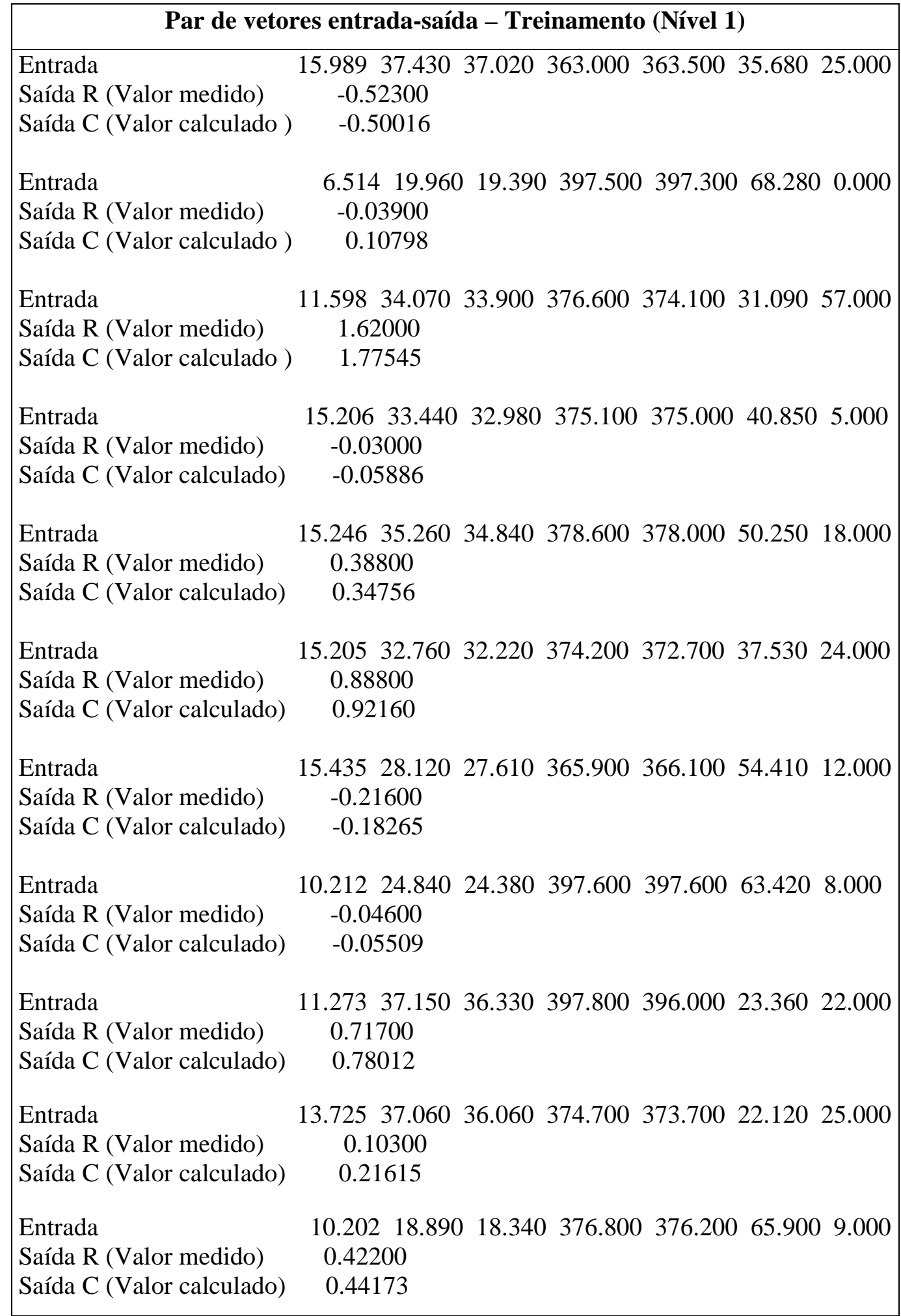


Tabela B.8 - Lista parcial dos resultados do teste para a combinação 5 (7 variáveis de entrada), primeiro conjunto (com todos os dados).

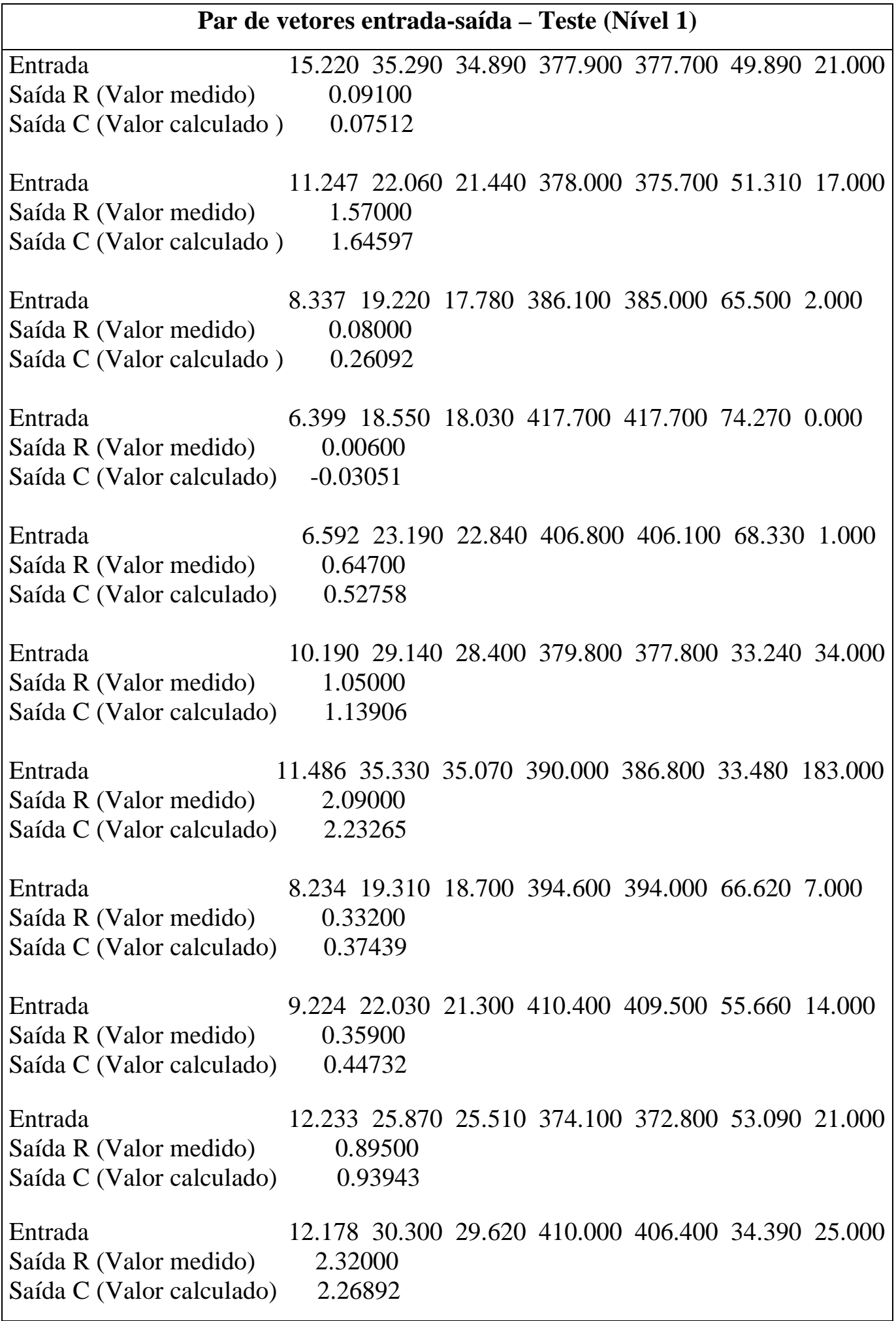


Tabela B.9 - Lista parcial dos resultados do treinamento para a combinação 7 (8 variáveis de entrada), primeiro conjunto (com todos os dados).

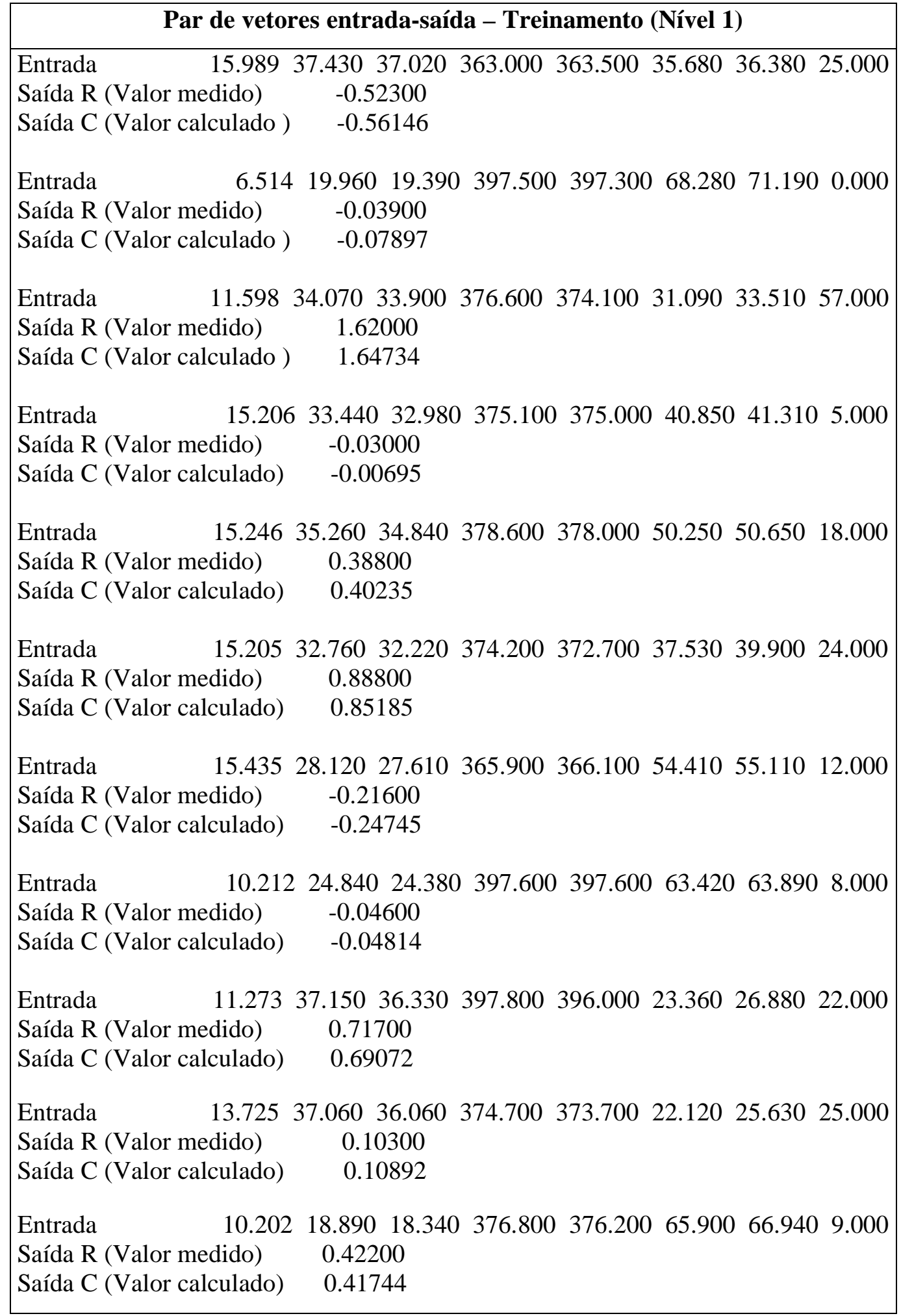


Tabela B.10 - Lista parcial dos resultados do teste para a combinação 7 (8 variáveis de entrada), primeiro conjunto (com todos os dados).

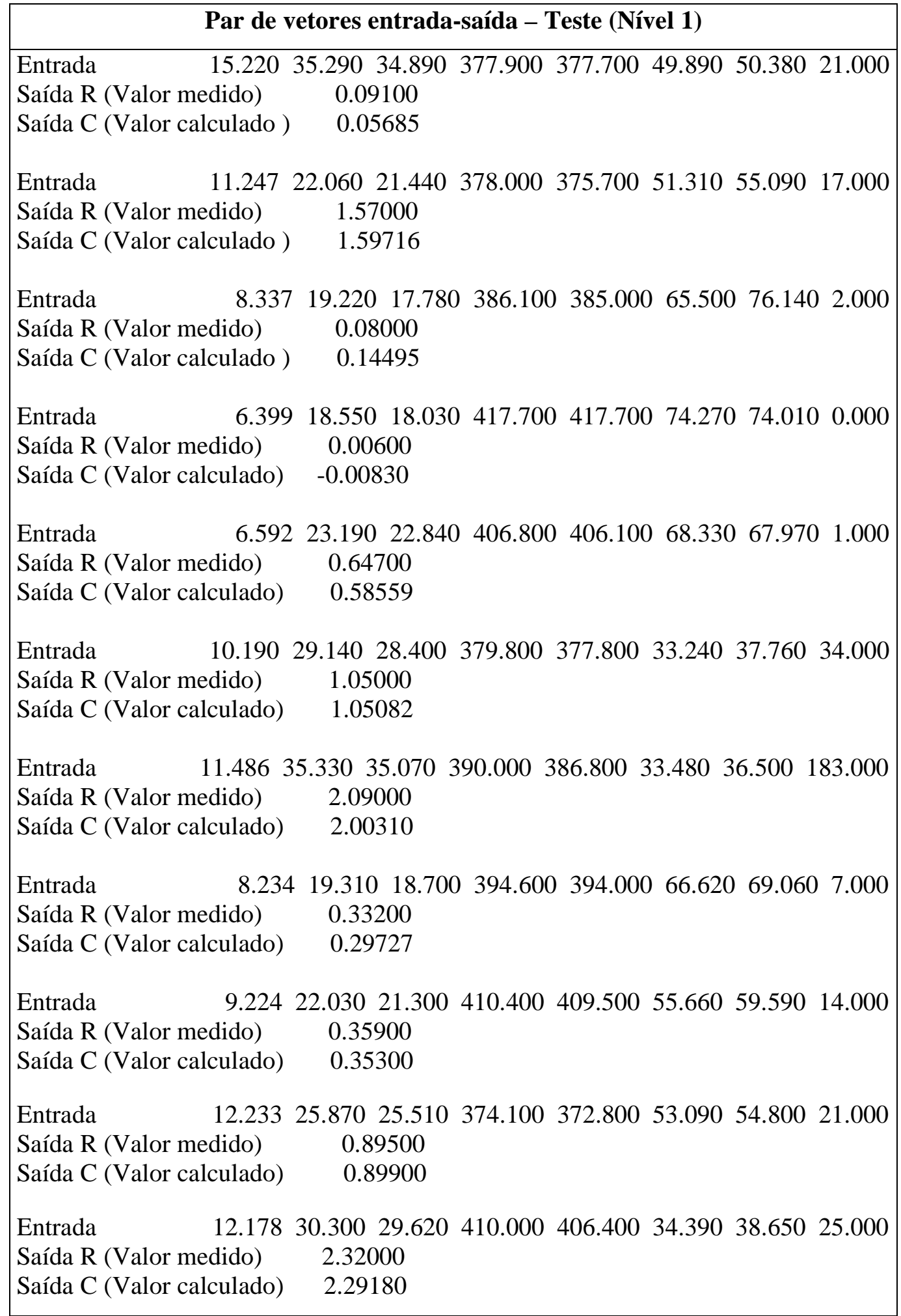


Tabela B.11 - Lista parcial dos resultados do treinamento para a combinação 1 (6 variáveis de entrada), segundo conjunto (com dados filtrados).

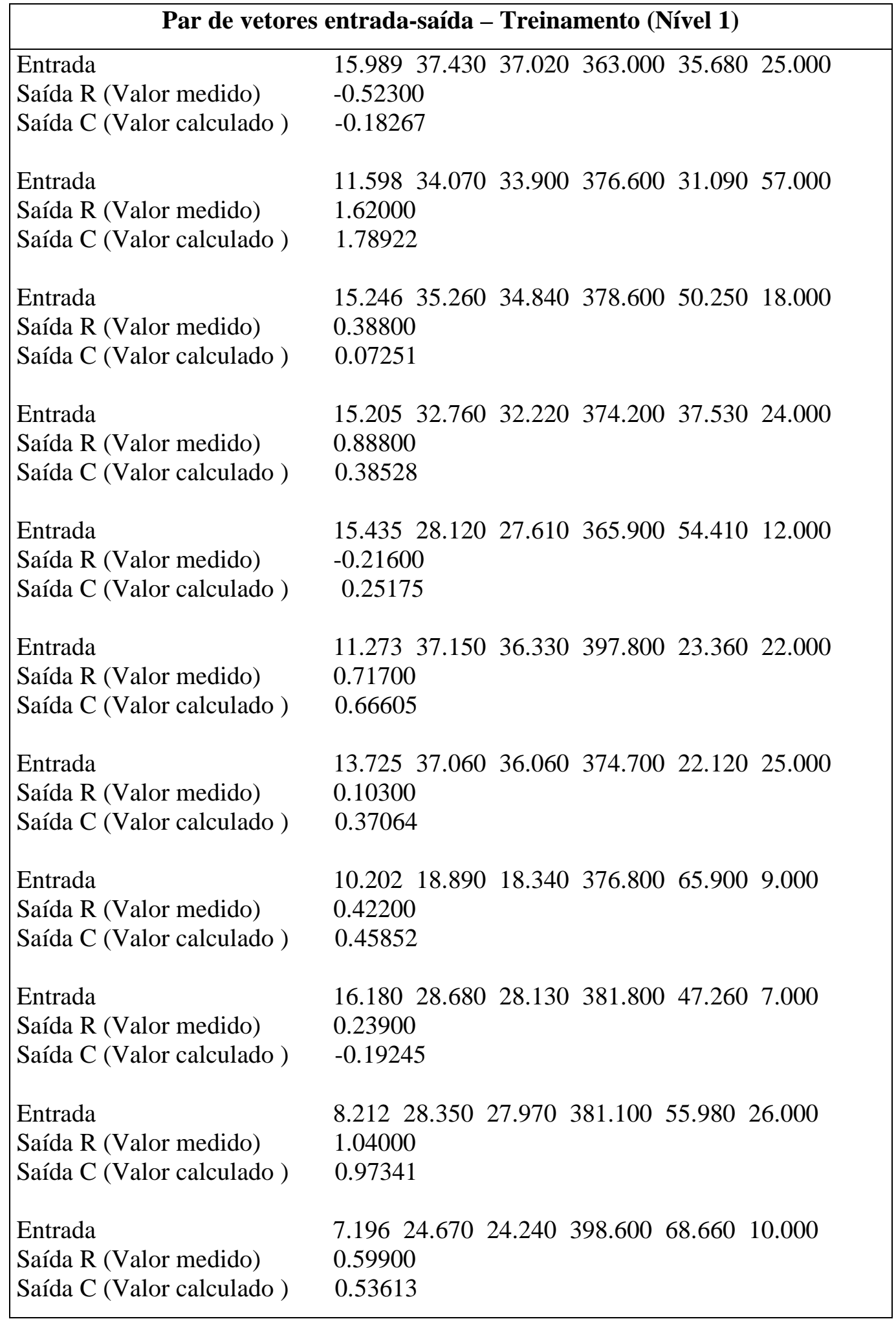


Tabela B.12 - Lista parcial dos resultados do teste para a combinação 1 (6 variáveis de entrada), segundo conjunto (com dados filtrados).

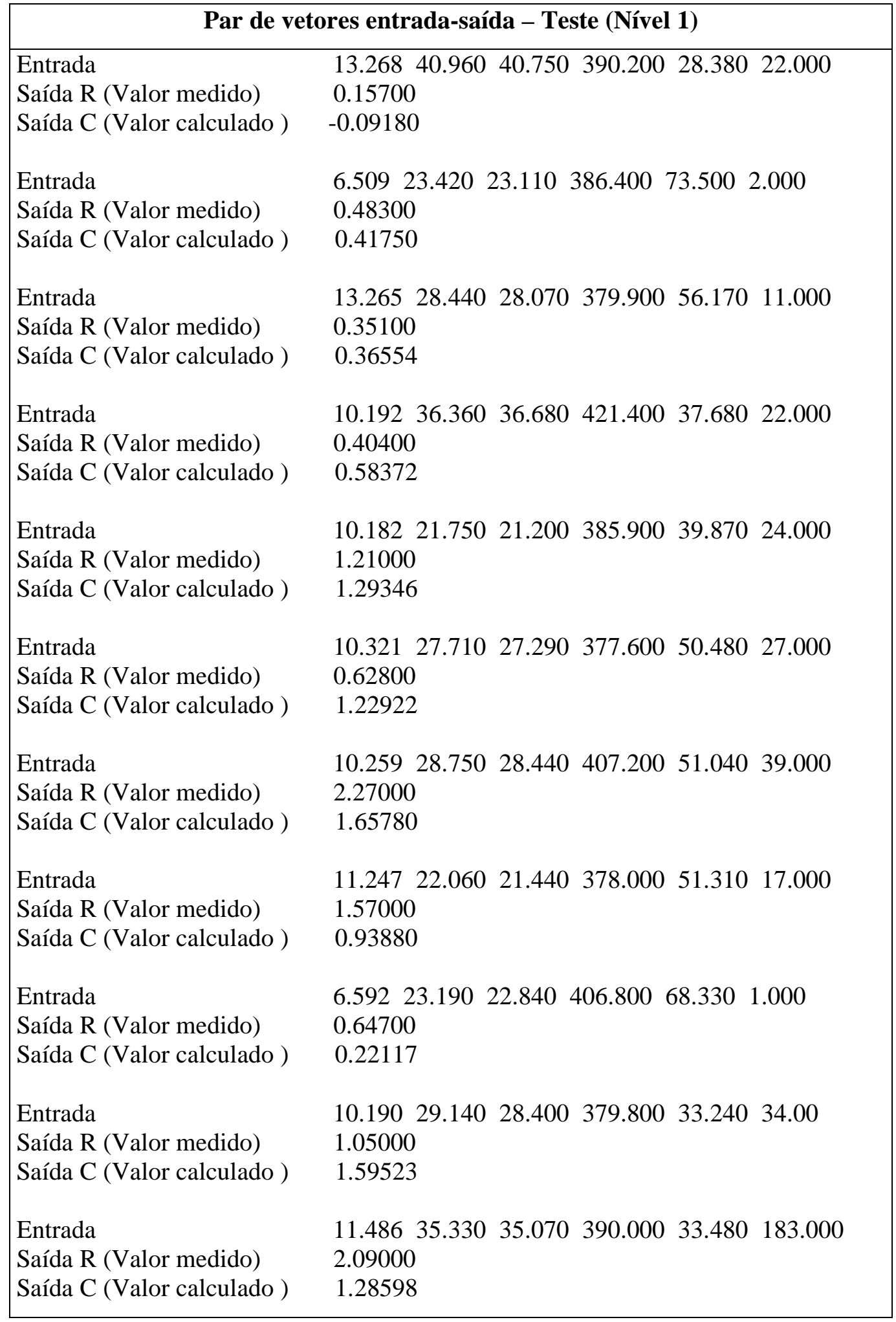


Tabela B.13 - Lista parcial dos resultados do treinamento para a combinação 5 (7 variáveis de entrada), segundo conjunto (com dados filtrados).

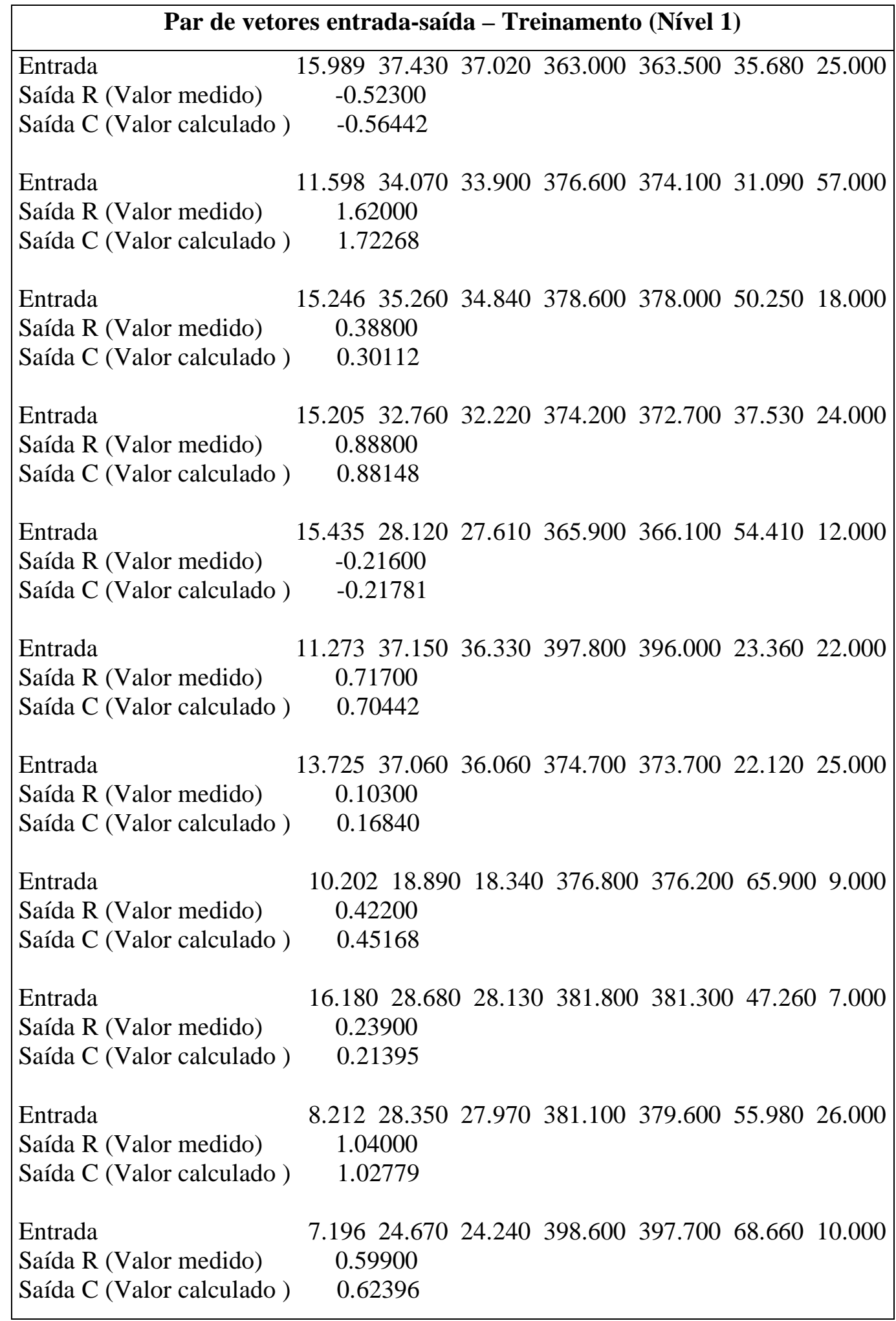


Tabela B.14 - Lista parcial dos resultados do teste para a combinação 5 (7 variáveis de entrada), segundo conjunto (com dados filtrados).

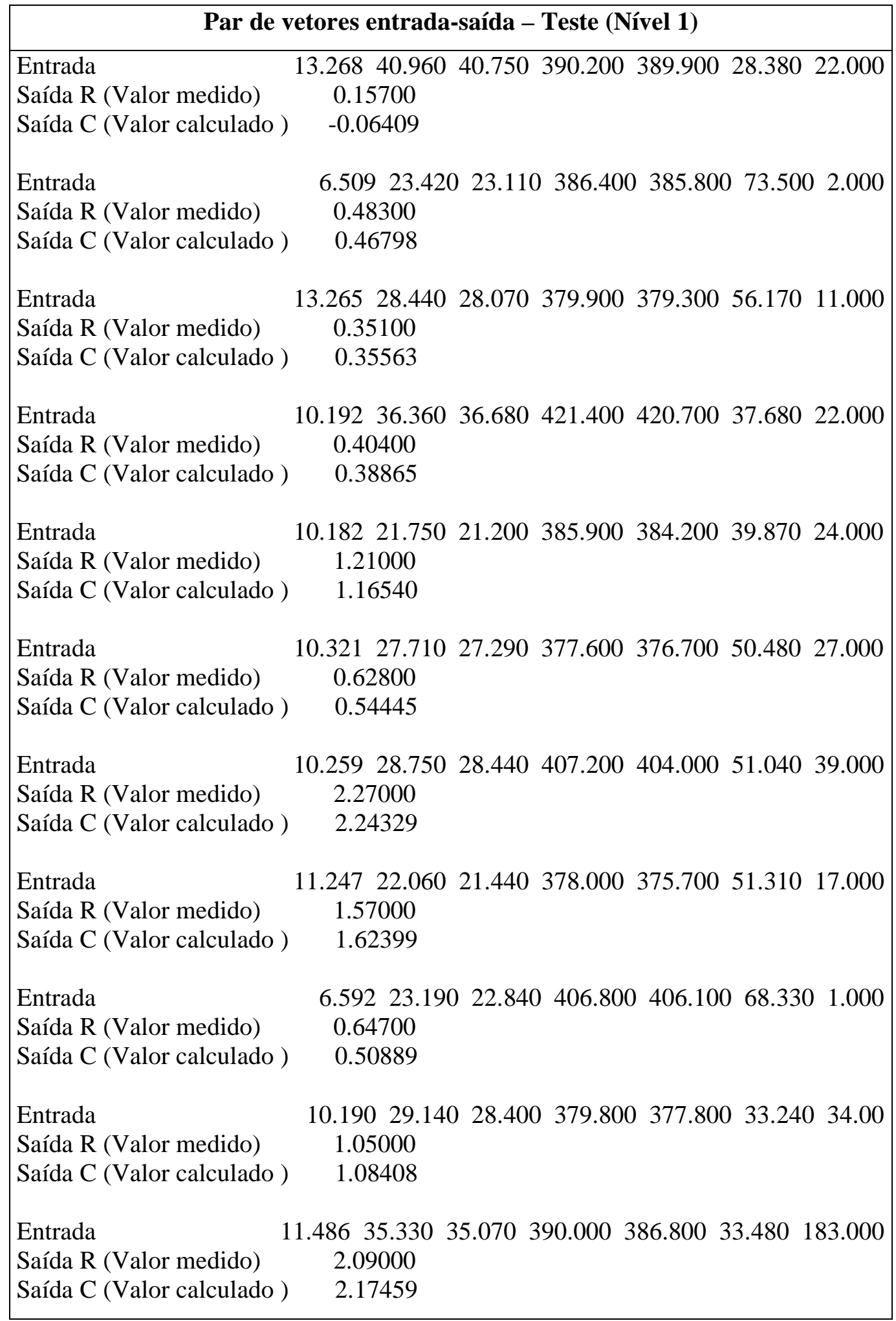


Tabela B.15 - Lista parcial dos resultados do treinamento para a combinação 7 (8 variáveis de entrada), segundo conjunto (com dados filtrados).

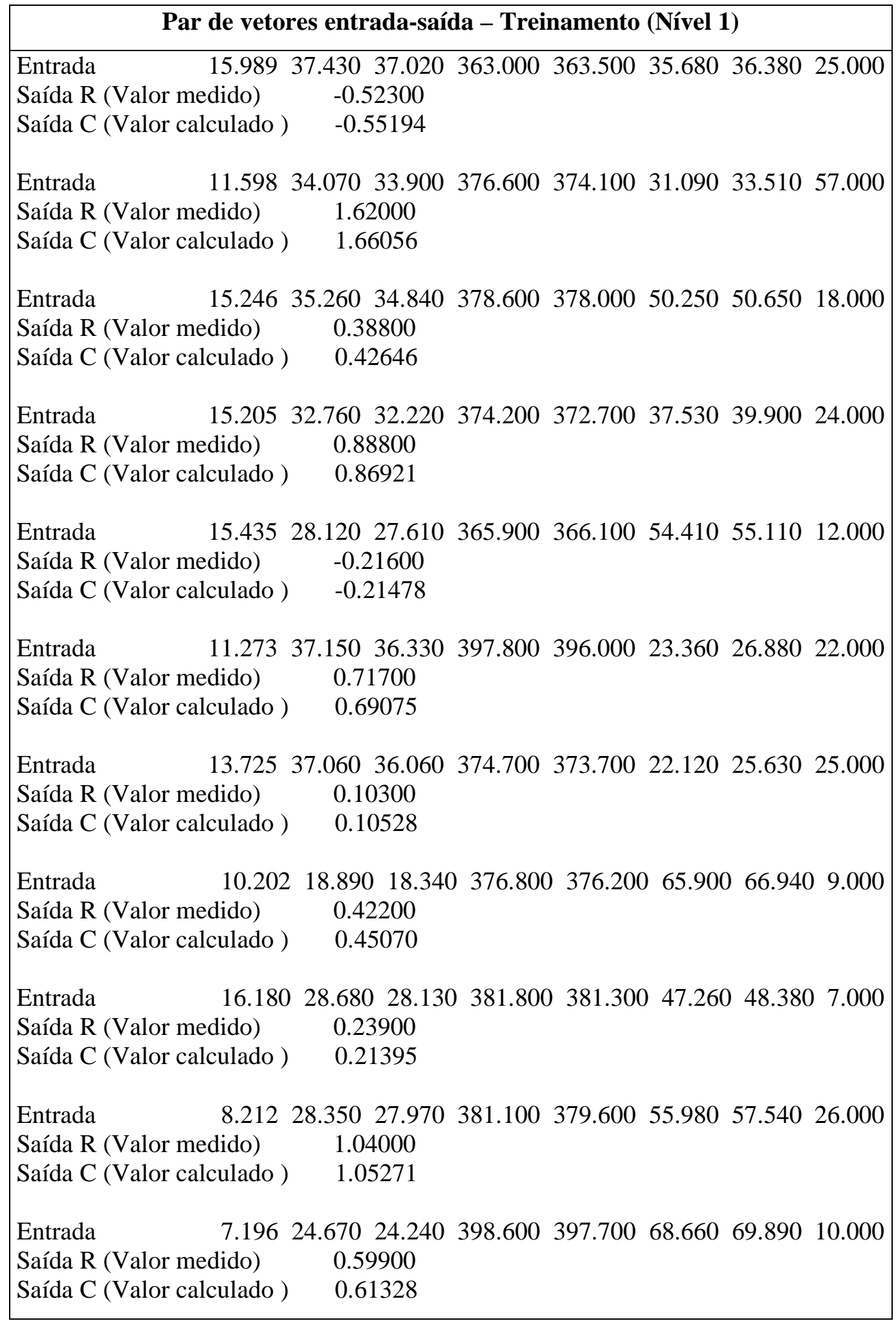


Tabela B.16 - Lista parcial dos resultados do teste para a combinação 7 (8 variáveis de entrada), segundo conjunto (com dados filtrados).

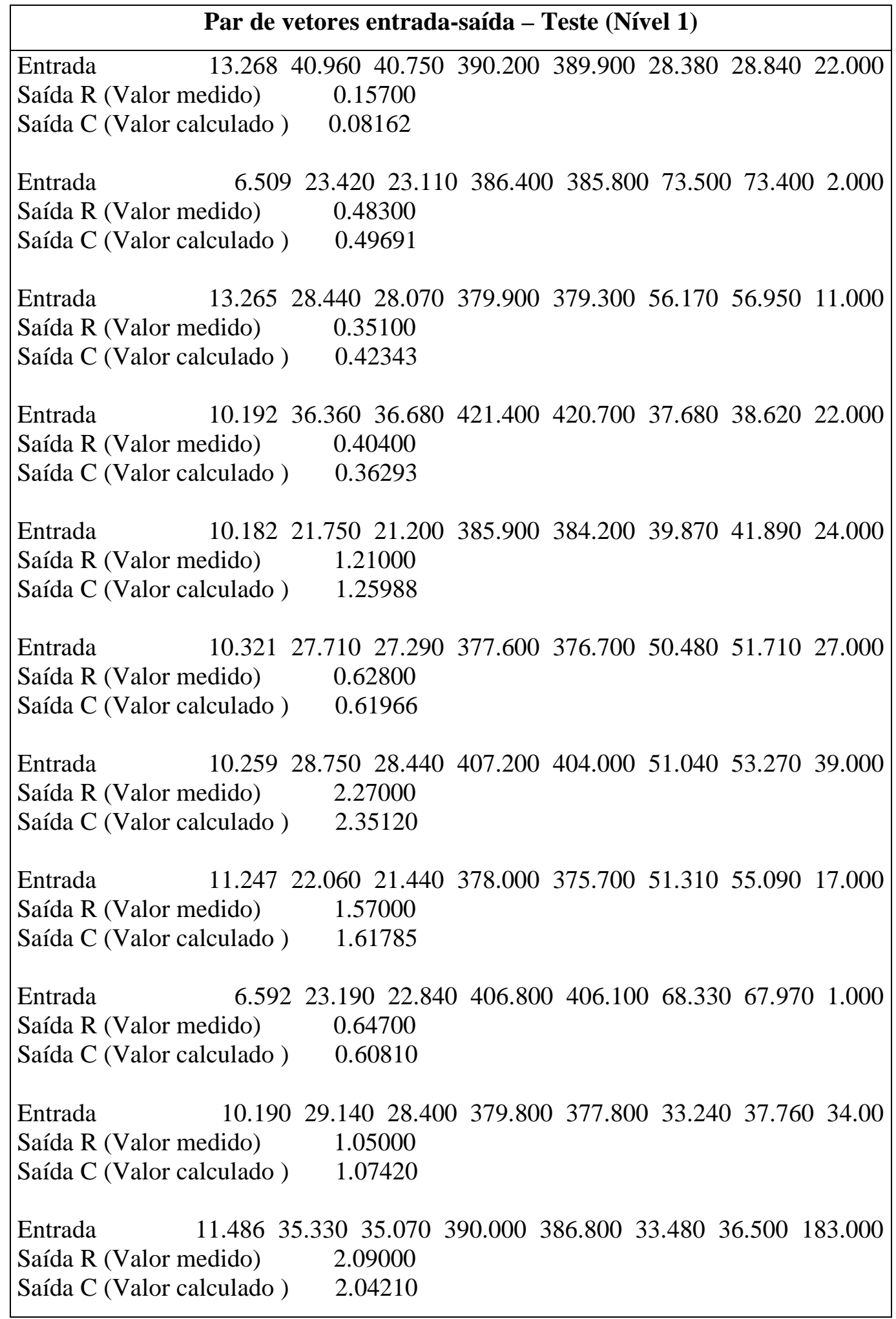


